UNIVERSIDADE DE SÃO PAULO

INSTITUTO DE GEOCIÊNCIAS

\title{
GEOLOGIA GLACIAL PERMO-CARBONÍFERA (SUBGRUPO ITARARÉ) NO FLANCO SUL DO ARCO DE PONTA GROSSA, PR
}

\author{
IVO TROSDTORF JUNIOR
}

Orientador: Prof. Dr. Antonio Carlos Rocha-Campos

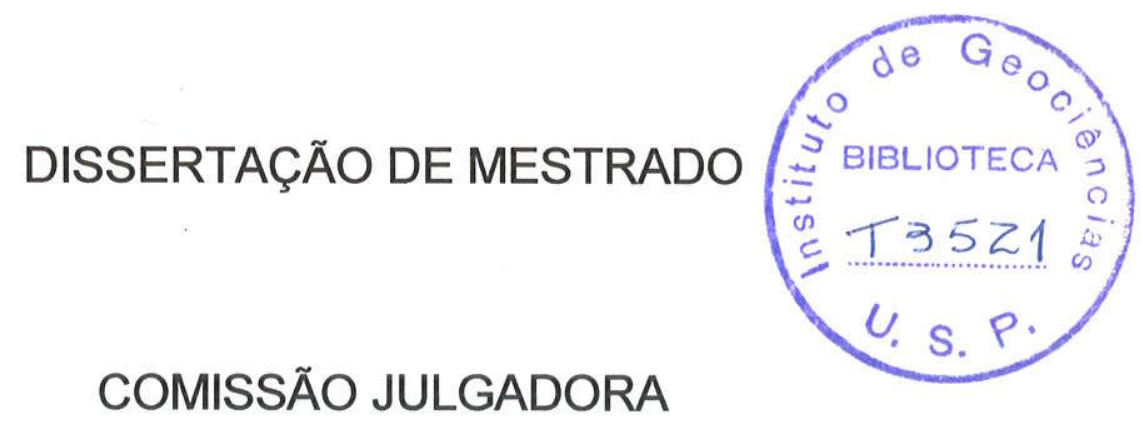

Nome

Assinatura

Presidente: Prof. Dr. Antonio Carlos Rocha-Campos thenmomp

Examinadores: Prof. Dr. José Alexandre de Jesus Perinotto

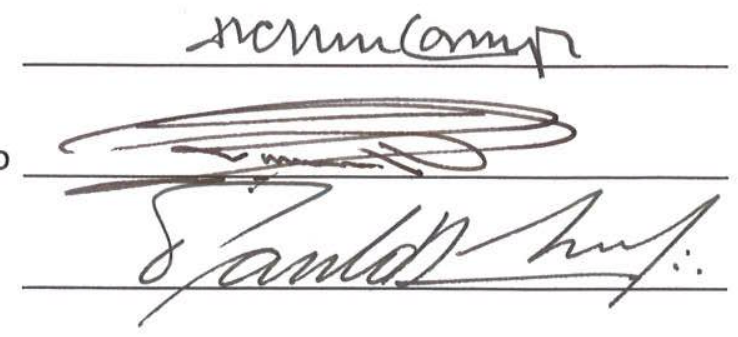

Prof. Dr. Paulo Roberto dos Santos

$$
\begin{aligned}
& \text { SÃO PAULO } \\
& 2002
\end{aligned}
$$

DEDALUS - Acervo - IGC

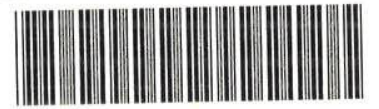




\section{Universule}

S. SPaulo

\section{世. Instituto de Ceociências}

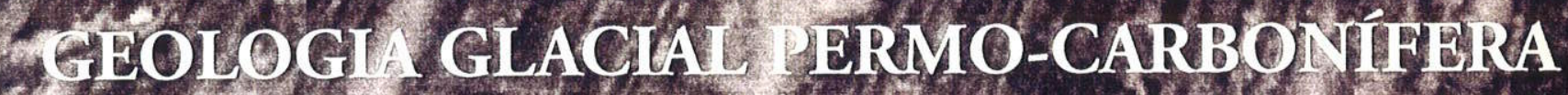
(SUbGR PO ITARARE) NO FLANCO SUL DO ARCODE PONTA GROSSA W y y

Ayo Trosdtorf Junio

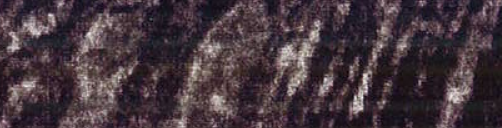

Ofentador Prof. Dr. Antonio Garlos Rocha-Canpos

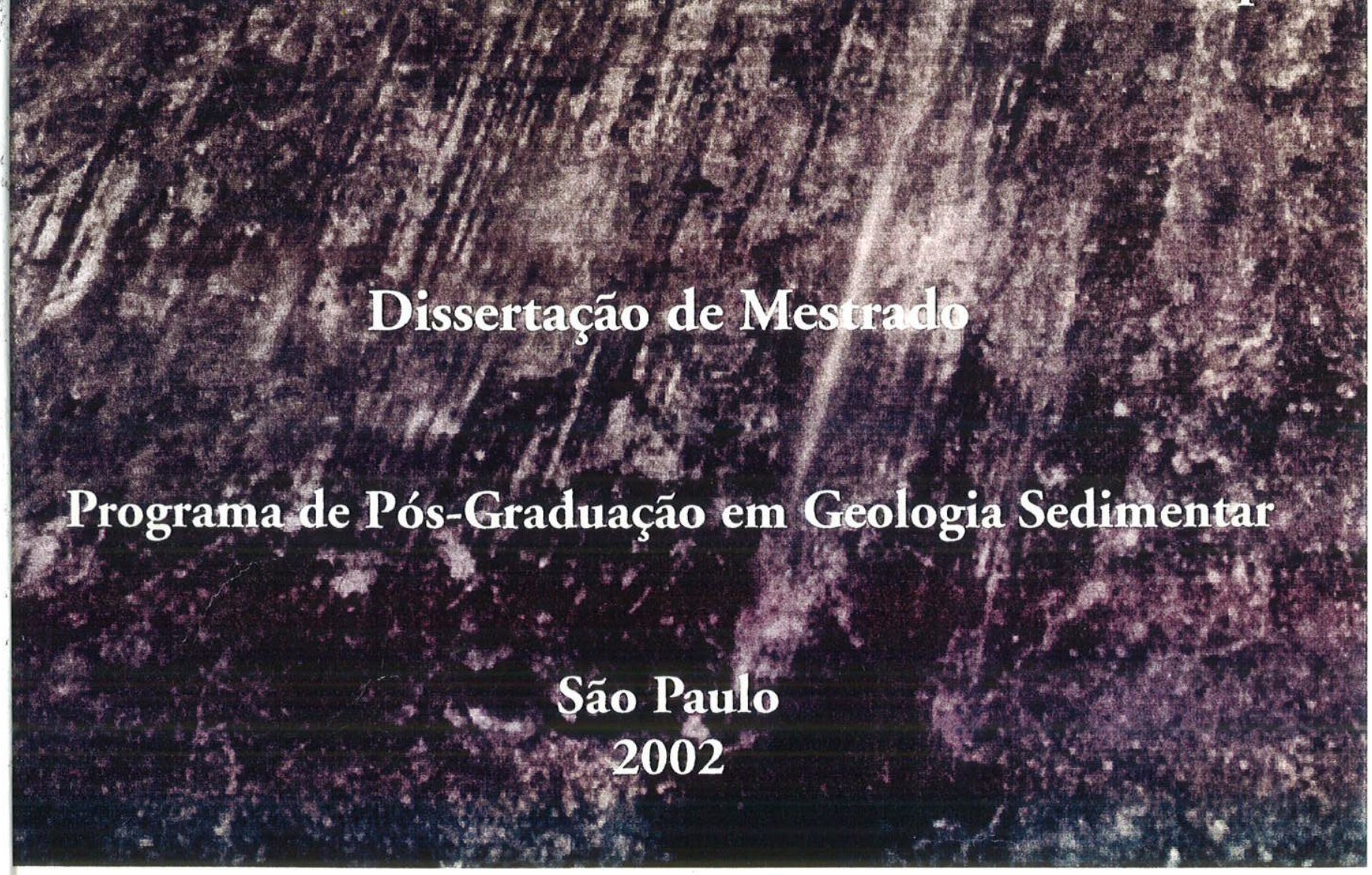


Sola Scriptura Solus Christus

Sola Gracia

Sola Fide

Soli Deo Gloria

(Princípios da Reforma Protestante do séc. XVI)

Aos meus pais, Ivo e Maria, que sempre me ensinaram essas verdades e ao meu avô, Leonardo (in memorian), pelo exemplo de perseverância e fé. 


\section{ÍNDICE}

\begin{tabular}{|c|c|}
\hline & PÁGINA \\
\hline INDICE DE FIGURAS E TABELAS & iii \\
\hline RESUMO & vii \\
\hline ABSTRACT & ix \\
\hline AGRADECIMENTOS & $\mathrm{xi}$ \\
\hline I - INTRODUÇÃO & 01 \\
\hline 1.1 - Processos glaciais erosivos e deposicionais no neopaleozóico & 01 \\
\hline 1.2 - Objetivos & 03 \\
\hline 1.3 - Área de estudo: contexto geológico & 04 \\
\hline 1.3.1- Tectônica regional & 08 \\
\hline I.4-Métodos & 15 \\
\hline II - EROSÄO E SEDIMENTAÇÃO SUBGLACIAL: FUNDAMENTOS TEÓRICOS & 18 \\
\hline III - FORMAS DE TERRENO GLACIAIS EROSIVAS E DEPOSICIONAIS & 32 \\
\hline 111.1 - Erosivas & 33 \\
\hline III.1.1 - Pavimento estriado de Witmarsum & 33 \\
\hline III.1.2 - Superficies estriadas de Palmeira & 35 \\
\hline III.1.3 - Superficies estriadas de São Luís de Purunã & 44 \\
\hline III.1.4 - Paisagem de abrasão glacial & 53 \\
\hline III.2 - Formas de terreno construcionais & 54 \\
\hline IV - DEPÓSITOS GLACIAIS DO SUBGRUPO ITARARÉ EM WITMARSUM. PR & 64 \\
\hline IV.1 - Mapeamento geológico & 64 \\
\hline IV.2 - Estratigrafia & 72 \\
\hline IV.2.1 - Perfil Colônia Witmarsum - BR-277 & 72 \\
\hline IV.2.2 - Seção Morro Siebert & 74 \\
\hline N.2.3-Estratigrafia glacial & 79 \\
\hline IV.3 - Estruturas associadas & 83 \\
\hline IV.3.1-Estruturas de colapso & 83 \\
\hline IV.3.2 - Feições periglaciais & 86 \\
\hline IV.3.2.1 - Estruturas em cunha & 87 \\
\hline IV.3.2.2 - Clastos partidos & 94 \\
\hline
\end{tabular}


IV.3.3-Outras feições glaciais e periglaciais fotointerpretadas

98

V - FENÔMENOS GLACIAIS E A EVOLUÇÃO TECTONO-SEDIMENTAR DO ARCO DE PONTA GROSSA

V. 1 - Evolução tectono-sedimentar do arco de Ponta Grossa

V.1.1 - Dados adicionais

V.2 - Feições glaciais no contexto da evolução geológica do arco

V.2.1 - Natureza da superfície pré-glacial

V.2.2-Preservação geológica da paisagem glacial

V.2.3 - Exumação e exposição atual da superficie glaciada

VI - CARACTERÍSTICAS DO LOBO GLACIAL PARANÁ

VII - PALEOGEOGRAFIA E HITÓRIA GEOLÓGICA

VII.1 - Fluxo glacial

VII.2 - Estratigrafia da área

VII.3 - História glacial

VIII - CONSIDERAÇÕES FINAIS

IX - REFERÊNCIAS BIBLIOGRÁFICAS

\section{ANEXOS}

Anexo 1: Mapa Geológico da Colônia Menonita de Witmarsum.

Anexo 2: Seção Geológica Witmarsum - BR 277.

Anexo 3: Quadro de correlação de diamictitos da área da Colônia de Wtimarsum. 


\section{ÍNDICE DE FIgURAS E TABELAS}

Título DAS FIGURAS
CAPiTULo
Figura 1-1: Localização da área de estudo e geologia regional do arco de Ponta Grossa.
Figura 1 2: Estereograma mostrando regime compressivo de esforços.
Figura 1-3: Paredão atrás da Companhia de Laticinios Cancela mostrando arenitos da
Formaçăo Furnas intensamente fraturados.

PÁGINA

Figura 1-4: Brecha de falha produzida pelo fahamento Cancela.

Figura 1-5: Plano de falha subvertical.

Figura 1-6: Arenito Furnas cavalgando diamictito Itararé.

Figura 1-7: Pavimento estriado cortado pela falha Cancela.

Figura 1-8: Geologia do embasamento da bacia do Paraná (Zalán et al. , 1990).

Figura 1-9: Mapa com as principais zonas de cisalhamento da Província Mantiqueira.

06

09

10

11

11

12

13

14

15

\section{Capitulo II}

Figura II-1: Distribuição da velocidade de fluxo do gelo em geleiras de diferentes regimes térmicos basais.

Figura 11-2: Diagrama esquemático para o regime termal basal.

Figura ll-3: Seção esquemática de três capas de gelo mostrando cenários de regime termal basai distintos.

Figura II-4: Diagrama ilustrando uma situaçăo hipotética de um tubo preenchido por água dentro de uma geleira e seu potencial hidráulico.

Figura II-5: Superficies equipotenciais de uma geleira.

Figura II-6: Esquema em planta de uma rede de cavidades interligadas.

Figura II-7: Representação gráfica do modelo de abrasão de Boulton (1974).

\section{CAPITULO III}

Figura III-1: Pavimento estriado de Witmarsum.

Figura III-2: Seção colunar do Subgrupo Itararé em Palmeira, PR.

Figura Ill-3: Superficie estriada inferior (A).

Figura III-4: Marcas de assentamento de objeto sobre a superfície estriada A.

Figura III-5: Camada siltomargilosa recobrindo parcialmente a superfície C.

Figura III-6: Estrias e sulcos sobre a superficie estriada B.

Figura III-7: Superfície estriada D. 
Figura III-8: Marcas onduladas assimétricas de direção de transporte para NNW.

Figura IIl-9: Deformação glaciotectônica em arenito abaixo da superfície estriada D.

Figura Ill-10: Vista geral da superfície estriada superior em São Luís de Purunã.

Figura III-11: Seção geológica de São Luís de Purunã.

Figura Ill-12: Aba de diamictito escorregado dentro de sulco a partir de crista.

Figura III-13: Clasto embutido em diamictito no fundo de sulco.

Figura III-14: Crista de sedimento depositado a jusante (na sombra) de clasto.

Figura III-15: Estrutura geometricamente semelhante a mini-flute.

Figura 1|l-16: Morainas de empurrão sazonais.

Figura 111-17: Visão geral de parte do afloramento atrás da Companhia de Laticínios Cancela.

Figura III-18: Camadas de arenito médio, dobradas e redobradas.

Figura II1-19: Diamictito branco, matriz siltica com clastos de diamictito vermelho.

Figura II-20: Visão parcial de estrutura em forma de colina identificada na Colônia de Witmarsum (PR).

Figura III-21: Pequena colina formada por diamictito arenoso deformado.

Figura III-22: Esquema de colina dômica de diamictito, corte obliquo.

Figura III-23: Foto na porção esquerda do esquema mostrado na Figura III-22.

\section{Capitulo IV}

Figura IV-1: Contato entre diamictito vermelho de matriz siltica e diamictito amarelo, de matriz arenosa.

Figura IV-2: Diamictito silto-arenoso, amarelo e com bandas avermelhadas, estratificado e dobrado.

Figura IV-3: Arenito grosso apresentando estratificação cruzada tabular de grande porte.

Figura IV-4: Arenito fino exibindo laminação cruzada acanalada de pequeno porte.

Figura IV-5: Imagem feita em microscopia eletrônica de varredura (SEM) e gráficos de EDS.

Figura IV-6: Imagem feita em MEV de siltito maciço e gráficos de EDS.

Figura IV-7: Seção levantada no morro atrás da Pousada Siebert em Witmarsum, PR.

Figura IV-8: Estratificação cruzada tabular, cortada por canal a $130^{\circ}$.

Figura IV-9: Arenito médio com lentes conglomeráticas e estratificação plano-paralela e cruzada de baixo ângulo.

Figura IV-10: Pavimento estriado e sulcado inferior. Seção Morro Siebert.

Figura IV-11: Diagrama triangular dos diamictitos analisados.

Figura IV-12: Diamictito silto-argiloso e deformado. 
Figura IV-13: Arenito médio-fino com granodecrescência ascendente.

Figura IV-14: Arenito conglomerático em contato por falha reversa com siltito laminado.

Figura IV-15: Energia livre da água e o ponto de congelamento.

Figura IV-16: Exemplos de diferentes tipos de fendas de congelamento do Pleistoceno.

Figura 1V-17: Cunha de areia (sand wedge).

Figura iV-18: Cunha de areia em diamictito estratificado.

Figura IV-19: Esquema de afloramento com sete estruturas em forma de cunha.

Figura IV-20: Afloramento onde há exposição de estruturas periglaciais.

Figura IV-21: Clastos partidos.

Figura IV-22: Clasto de arenito Furnas partido.

Figura IV-23: Clasto partido com pelicula de limonita.

Figura IV-24: Fotointepretação de aigumas feições glaciais e periglaciais com morfologia preservada.

\section{Capitulo V}

Figura V-1: Projeção da espessura do Subgrupo Itararé em direção ao arco de Ponta Grossa.

Figura V-2: Alinhamentos estruturais que compõem o arco de Ponta Grossa.

Figura V-3: Mapas de isoespessura dos intervalos bioestratigráficos $\mathrm{G}, \mathrm{Hel}_{1}$.

Figura V-4: Isoespessura do Itararé inferior (Fulfaro et al., 1980).

Figura V-5: Isoespessuras dos intervalos bioestratigráficos do Subgrupo Itararé.

Figura V-6: Seções cronoestratigráficas do Subgrupo Itararé.

Figura V-7: Curvas médias do eixo central e flanco sul do arco de Ponta Grossa.

Figura V-8: Curvas de subsidência do Subgrupo Itararé, poços 2-CS-1-PR e 2-O-1-PR.

Figura V-9: Correlação dos ciclos estratigráficos do Subgrupo Itararé.

\section{CAPITULO VII}

Figura VII-1: Estratigrafia glacial da área.

Figura VII-2: Direções das estrias sobre a Formação Furnas e o Subgrupo Itararé.

Figura VIl-3: Mapa geológico compilado.

Figura VII-4: Esquema provisório de correlaçäo. 
CAPÍtulo III

Tabela III-1: Classificação das formas de terreno glaciais erosivas e deposicionais.

\section{CAPITULO IV}

Tabela IV-1: Temperatura minima, máxima e $\triangle T$ dos anos de 1999 e 2000.

Tabela IV-2: Variação anual de temperatura em regiôes com clima periglacial atual. 


\section{RESUMO}

Formas de terreno glaciais de micro e meso-escala (estrias, sulcos, cristas de tilito ou flutes) que ocorrem sobre arenito da Formação Furnas (Devoniano) ou arenito flúvio-glacial e tilito subglacial Subgrupo Itararé (neopaleozóico), configuram, pelo menos, duas extensas paisagens de abrasão glacial de mais de $1.500 \mathrm{~km}^{2}$ da área, exumadas e excelentemente preservadas, no flanco sul do arco de Ponta Grossa. Feições sobre o arenito Furnas foram erodidas por geleira deslizando sobre substrato "duro"/consolidado; e "mole" ou inconsolidado, no caso dos sedimentos neopaleozóicos. O comportamento reológico distinto reflete-se em diferenças nas feições presentes sobre os dois tipos de substrato. Aração subglacial foi o processo erosivo predominante em ambos os casos, ocorrendo sob geleira de base quente e na presença de água de degelo.

A despeito do caráter consolidado do substrato Devoniano, formas de terreno glaciais erosivas positivas, tipo rochas moutonnées e dorsos de baleia, não ocorrem na região estudada. Isto deve-se ao fato de a geleira, de base plana, deslocar-se sobre substrato previamente aplainado (peneplano) durante longo periodo erosivo pré-itararé, e de composição litológica, inicialmente, homogênea, e de disposição horizontal, que deve ter influenciado a erosão glacial.

Estriações são retilineas e paralelas sobre cada uma das paisagens abrasivas. Entrecruzamento de estriações de orientação diferente sobre a mesma superficie não foram encontradas, indicando formação por um único evento erosivo em cada caso.

A orientação média das estriações é de N12W sobre o arenito Devoniano, e N20E sobre depósitos do Subgrupo Itararé, indicando considerável mudança no padrão de fluxo da geleira. Os dois eventos de abrasão glacial foram anteriormente atribuídos a duas distintas "glaciações" sucessivas, denominadas, respectivamente, Rio do Salto e Cancela, porém devem corresponder a dois eventos menores de avanço da geleira.

Duas exposições de superfícies estriadas, formadas sobre rochas do Subgrupo Itararé, de especial significado em Geologia Glacial pela quantidade e diversidade de feições preservadas, ocorrem sobre arenito flúvio-glacial e glácio-marinho proximal em Palmeira, e diamictitos (tilito de alojamento) em São Luis de Purunã. Neste último local, formas de terreno glaciais deposicionais de pequeno porte, do tipo flute, foram encontradas. Trata-se do primeiro registro destas feições em sucessões glaciais pré-pleistocênicas. 
A correlação entre essas superfícies e as que se situam sobre rochas do Subgrupo Itararé em outros afloramentos, não está ainda clara. Nos dois casos, as superfícies são múltiplas, refletindo oscilação da margem da geleira neopaleozóica, envolvendo alternância de condições de alta velocidade e erosão, e baixa velocidade e deposição. A despeito de sua origem subglacial não há evidências de deformação intensa por esforço cisalhante. $A$ preservação dessas feições de erosão posterior ocorreu pela deposição de till subglacial e/ou pela sedimentação subaquática de silte.

Excelentes exposições do Subgrupo Itararé em Witmarsum permitem distinguir várias sucessões de diamictitos, incluindo tilitos subglaciais e supraglaciais associados a, no mínimo, sete episódios de avanço e recuo da geleira. Durante uma dessas fases, verificouse a instalação de condições periglaciais, documentadas pela ocorrência de cunhas de areia (sand wedges) e clastos partidos. Intercalações de arenitos marinhos rasos no pacote de diamictitos indicam a ocorrência de eventos marinhos transgressivos pós-glaciais. Depósitos coliniformes de diamictito deformado identificados na seção estudada, são interpretados como morainas de empurrão sazonais, associadas a oscilações da margem da geleira. A preservação dessas formas de terreno constitui registro singular e inédito em sucessões glaciogênicas pré-pleistocênicas.

Os diversos ciclos estratigráficos glaciais reconhecidos no Subgrupo ltararé, no flanco sul do arco de Ponta Grossa, são atribuiveis à combinação de episódios de avanço e recuo do lobo glacial Paraná e movimentos glácio iso- e eustáticos. Esses movimentos ocorreram no contexto de eventos tectônicos de maior escala, ligados à evolução tectônica do arco de Ponta Grossa no neopaleozóico. 


\begin{abstract}
Landforms of glacial erosion of micro- to meso-scale (striae, furrows, flutes) occur on sandstone of the Furnas Formation, and on fluvio-glacial and subglacial tillite from the Itararé Subgroup. They make up two superposed extense landscapes of glacial abrasion of over $1.5000 \mathrm{~km}^{2}$ of area, exhumed and excellently preserved, on the southern flanck of the Ponta Grossa arch. Features on the Furnas sandstone have been eroded by a glacier flowing on a hard (consolidated) bed; the substratum was soft or inconsolidated on the Paleozoic sediments. The different reologic behavior of the glacier bed is reflected on differences of features present on the two types of glacial substrata. Glacial plowing was the predominant erosional process in both cases, associated to a warm based glacier and presence of subglacial meltwater.

In spite its hardness, positive glacial erosional features, as roches moutonnées, whale backs, etc., do not occur on the Devonian sandstone. This is due to the glacier having displaced on a previourly existing peneplain formed during a pre-ltararé Subgroup regional erosional phase, plus the homogenous lithology and horizontal disposition of beds.

Striations are rectilinear and parallel on each abraded landscape. Intersection of striae with different directions was not found, indication a single erosional event in each case.

The mean direction of striations vary from $\mathrm{N} 12^{\circ} \mathrm{W}$ to $\mathrm{N} 20^{\circ} \mathrm{E}$ on the Devonian and late Paleozoic rocks respectively. Sense of glacier movement was toward north. The two glacial erosional events have been assigned to two different successive "glaciations", named Rio do Salto and Cancela, but correspond most probably to events of glacier advance.

Two exposures of striated surfaces on the fluvio-glacial and glacial-marine beds an on lodgement tillite of Itararé Subgroup in Palmeira and São Luís de Purunã, respectively, exhibit a variety of features and bear special importance in terms of Glacial Geology. In the later outcrop depositional glacial landsforms similar to glacial flutes have also been found. This is the first record of such features in the pre-Pleistocene succession. Correlation between these surfaces and those on top of Itarare elsewhere on the Ponta Grossa arch rocks is not entirely clear. In the two cases above the surfaces are multiple, reflecting oscilation of the glacier margin and alternating conditions of fast flow and erosion and slow flow and deposition. In spite of their subglacial origin, no evidence of strong shear deformation was found. Features were preserved from further erosion by a cover of subglacial till or of a bed of silt deposited on top of striated surfaces.
\end{abstract}


Excellent exposures of Itararé Subgroup rocks at Witmarsum contain several diamictite successions made up of subglacial and supraglacial tillites resulting from at least seven episodes of advance and retreat of the glacier. During one of those phases periglacial conditions occurred as documented by sand wedges and frost shattered clasts. Intercalation of shallow marine sandstone beds in the diamictite section indicate post-glacial, marine transgressive events. Hill-like deposits of deformed diamictite found in the studied area were interpreted as seasonal push moraines, resulting from oscilation of the glacier margin. Preservation of this type of proglacial landform is unique in pre-Pleistocene glaciogenic successions.

The several stratigraphic cycles recognized in the Itararé Subgroup in the study area, have probably been controled by a combination of advance and retreat of the Paraná glacial lobe and associated glacio eu- and isostatic movements. These movements occurred in the context of larger scale tectonic events, that look place during the tectonic evolution of the Ponta Grossa arch in the late Paleozoic. 


\section{AGRADECIMENTOS}

Apesar de qualquer dissertação ser considerada um trabalho individual, esta só foi possível graças ao auxílio de um grande número de pessoas e instituições. É certo também que nem todas as pessoas que ajudaram, direta ou indiretamente para o término deste mestrado, serão aqui lembradas, cuja culpa recai certamente sobre falhas de minha memória e a "correria" característica de todo término de mestrado. Sendo assim, quero expressar, desde já, minha gratidão a todos que porventura não estejam aqui relacionados.

Com certeza, grande parte dos resultados atingidos deve-se a orientação segura e constante do Prof. Dr. Antonio Carlos Rocha-Campos. O estilo de orientação do Prof. RochaCampos é algo realmente peculiar; poucos orientadores mostram tanta disposição e entusiasmo pela pesquisa quanto ele, a ponto de calejar as mãos no cabo da enxada, juntamente com o orientado, limpando afloramentos. Contudo, devo confessar que em muitos momentos meu desempenho com a enxada deixou a desejar, principalmente quando comparada com a do mestre. Sem dúvida, o aprendizado proporcionado pelo Prof. RochaCampos durante esses três anos ficarão marcados em minha vida, e as experiências vividas e adquiridas serão extremamente importantes, tanto em minha vida profissional, quanto pessoal. Sua participação e experiência de mais de 35 anos em Geologia Glacial foram fundamentais para o término desta dissertação. Em muitos momentos, sua dedicação e amor à pesquisa serviram-me de exemplo e estímulo, principalmente nas horas de desânimo e dúvida, que às vezes me abateram no transcorrer deste trabalho. Sendo assim, essas poucas palavras de gratidão e admiração não refletem de maneira adequada toda a importância que reconheço no Prof. Rocha-Campos, não apenas para a realização desta dissertação de mestrado, mas para diversos ex-orientados, alunos e para a Geologia Glacial brasileira e internacional como um todo.

Também devo uma palavra de gratidão ao Prof. Dr. Paulo R. dos Santos. Tive a honra de ser seu orientado durante meus anos de graduação e desde àquela época tenho tipo o privilégio de pertencer ao mesmo Grupo de Pesquisa que o mestre faz parte. Minha formação em Geologia Glacial teve e ainda tem muita influência das idéias do Prof. Paulo e este trabalho apresenta muitas de suas concepções. Seu auxilio tanto nos trabalhos de campo, como nas discussões e na revisão do texto apresentado, foi extremamente importante e valiosa. Seu valor como pesquisador e professor é inegável, mesmo quando não reconhecido pela "aristocracia acadêmica". Contudo, seu valor não está em suas 
importantes publicações e nem na dedicação incansável ao ensino da estratigrafia, disciplina que todo ano melhora e renova, mas em seu caráter. O Prof. Paulo pertence àquele grupo reduzido e seleto de pessoas, cujas qualidades estão cada vez mais escassas dentro de nossa sociedade. Sua vocação ao ensino e a educação não se limita às aulas, em diversos momentos, durante todos esses anos de convívio, pude presenciar muitos alunos o procurarem atrás de conselhos que vão além de questões geológicas. Sua coragem para falar aquilo que pensa e sente, e também de ouvir e de analisar de coração aberto, mesmo vindo de um simples estagiário, que um dia fui, faz dele um amigo sincero e leal que muito me honra ter.

Meu muito obrigado ao Prof. Dr. José R. Canuto, pela confiança em mim depositada ao fornecer dados ainda não publicados de sua excelente pesquisa sobre Estratigrafia de Seqüências no Subgrupo Itararé, e pela amizade incondicional dispensada a este seu exaluno e orientado. Também quero agradecer ao Prof. Dr. George Sadowiski, pela ajuda oferecida nos trabalhos de campo e pelas discussões sobre a geologia estrutural da área e ao Prof. Dr. Paulo C.F. Giannini, pelo auxílio com as descrições petrográficas.

Minha gratidão ao Ms. Alexandre Tomio, doutorando do Instituto de Geociências USP, pelo auxílio e companheirismo em todos os trabalhos de campo realizados, e pelas discussões, que não foram poucas, sobre a Geologia Glacial da área.

Aos diversos colegas de pós-graduação do Programa de Geologia Sedimentar, Afonso, Alethéia, André Ferrari, "Bruce", Denise, Graziela, Juliana Nunes, Juliana Leme, Leandro "Itaquera", Liliane, Marília, "Ninguém", Paulo Albuquerque, Paula Amaral ( $\pi$ ), Renata, Renato Ghilardi, Rogério, Sabrina, pelas discussões sobre o trabalho e laços amizade construidos ao longo desses três anos, e aos demais colegas de pós-graduação, Alexandre "Tobias", "Baga", Claudia "Vali", Claudio, Cristiane, "Edir", George, "Gummi", Janaina, Lucelene "Val", Marcelo Rocha, Mika, Neide, Silvia e Valéria, por sua amizade e apoio em todos os momentos da realização desta dissertação. Aos vários colegas de graduação, em especial à Deborah pela ajuda no primeiro trabalho de campo realizado e a Antônio, Conrado, Deise, Gabriel, Juliana "Kola", Márcia, Marcos "Piolho", Rodrigo, Sibele e Sueli pela amizade constante.

À Carmen da Gastehaus Pousada Siebert e aos moradores da Colônia Menonita de Witmarsum, pela hospitalidade com que receberam a mim e meu orientador, propiciando momentos extremamente agradáveis durante nossa estada. 
Aos funcionários do Instituto de Geociências - USP, em especial aos técnicos Isaac (laboratório de MEV) e Elaine (laboratório de Sedimentologia) pela ajuda oferecida, sem a qual não seria possivel concluir este trabalho. Também não poderia me esquecer de agradecer a duas pessoas muito especiais, Ana Paula e Magali, da Secretaria de PósGraduação, pelas várias dúvidas sanadas e pela amizade dispensada à minha pessoa.

À Fundação de Amparo à Pesquisa no Estado de São Paulo (FAPESP), pela concessão da bolsa de estudo (Proc. 1999/07189-2) e do projeto de pesquisa (Proc. 2000/12125-2), que financiou parte dos trabalhos de campo realizados.

Ả minha familia, Ivo, Maria, Priscila, Wilians, Alessandra e o pequeno João Leonardo, pelo seu carinho e por sempre acreditar em minha capacidade, mesmo quando as circunstâncias diziam que não. À minha "família" da fé, por seu amor para comigo e minha família, e pelos diversos momentos em que figurei em suas orações.

Ao AUTOR DA VIDA, minha razão de existir e de viver, sem o qual nada do que faço ou almejo fazer faria sentido. 


\section{1 - INTRODUÇÃO}

\section{I.1 - Processos glaciais erosivos e deposicionais no neopaleozóico}

Uma das questões atuais mais controvertidas da geologia glacial e glaciologia, refere-se às formas de interação entre geleiras e seus diferentes substratos (glacier bed), e aos processos glaciológicos, reológicos e sedimentares que ocorrem subglacialmente, particularmente sob mantos de geio terrestres. Uma pesquisa, mesmo superficial, da literatura internacional moderna sobre glaciologia e geologia giacial recente e quaternária, demonstra claramente essa situação. As questões vêm sendo tratadas, nos últimos anos, em sucessivas reuniões científicas internacionais especializadas. O simpósio internacional sobre: "Glaciers and the Glaciated Landscapes", organizado pela International Glaciological Society, em Kiruna, Suécia (1998) e a Sessão Temática sobre: "Subglacial Processes and the Behaviour of /ce Sheets", na reunião anual da Geological Society of America, em Denver, EUA (1999), são dois exemplos de conclaves recentes voltados ao tema.

Com efeito, em razão das dificuldades de acesso que apresentam à observação direta, o ambiente subglacial é um dos menos conhecidos do sistema deposicional glacial-terrestre. Sendo assim, os processos e mecanismos de erosão e deposição subglacial não estão inteiramente compreendidos. Há, portanto, poucos modelos teóricos que abordam os tópicos acima. Exceções são os modelos desenvolvidos por Boulton (1974) para erosão e deposição subglacial e Hallet (1979) para erosão glacial. A despeito dessas limitações, numerosa bibliografia trata de processos subglaciais inferidos a partir da análise de formas de terreno erosivas e deposicionais reveladas pela deglaciação. Destes, os mais freqüentes referem-se à origem de drumlins e eskers (Smalley e Unwin, 1968; Banerjee e McDonald, 1975; Shaw, 1983; Menzies, 1987; Boulton, 1987; Brennand, 1994; Hart, 1995 e outros).

Dentre as formas de terreno erosivas, são particularmente interessantes as superfícies e pavimentos estriados ${ }^{1}$, pois além de fornecerem evidências sobre processos de abrasão glacial, podem dar indicações sobre a natureza dos mecanismos deposicionais subglaciais, associados a alojamento de clastos, através, por exemplo, de aração (plowing), permitindo interpretar as características das geleiras que as produziram (Clark e Hansel, 1989; Bennett e Glasser, 1996; Benn e Evans, 1998).

Formas de terreno glaciais deposicionais (morainas, eskers, drumlins etc.) são de difícil preservação e, mais ainda, de identificação, no registro glácio-sedimentar pré-

\footnotetext{
1 Neste texto diferenciamos pavimentos estriados glaciais (formados sobre substrato consolidado) de superfícies estriadas glaciais (geradas sobre substrato não consolidado ou "mole").
} 
pleistocênico, havendo poucos casos descritos na literatura (Frakes et al., 1969; RochaCampos, 1972).

Pavimentos e superfícies glácio-estriados são, entretanto, de ocorrência relativamente comum, associadas a sucessões glaciogênicas de várias idades (ver Hambrey e Harland, 1981; Menzies, 1996), constituindo evidências frequentemente apontadas em favor da origem glacial de diamictitos e outras rochas imediatamente superpostas.

A potencialidade do exame dessas formas de terreno (landforms) para o esclarecimento de várias questões de Geologia Glacial incentivou a procura de locais adequados ao desenvolvimento de estudo sobre o tema. A ocorrência de superfícies estriadas glaciais múltiplas, intraformacionais no Subgrupo Itararé no sul do arco de Ponta Grossa, em afloramento anteriormente estudado por Canuto (1985) e RochaCampos et al. (1999), e as informações de literatura sobre a existência de numerosas exposições de pavimentos e superfícies glacialmente estriadas na área (Bigarella et al., 1967; Fuck e Bigarella, 1967; Vesely e Assine, 1998) motivaram a seleção dessa região para estudo.

Duas questões fundamentais da geologia glacial neopaleozóica da Bacia do Paraná, decorrentes das características acima apontadas, constituem o cerne da presente dissertação:

a) identificação e estudo de formas de terreno (erosivas e deposicionais) subglaciais resultantes da interação geleira/substrato, indicativas de condições de regime térmico do gelo, reologia do assoalho glacial, regime hidrológico e dinâmica do lobo glacial Paraná, na parte sul do arco de Ponta Grossa; e

b) análise e interpretação das circunstâncias geológicas que condicionaram a geração e posterior preservação dessas formas de terreno, mesmo que descontinuamente, em uma região tão ampla, nos contextos do sistema deposicional glacial e da evolução tectônica da área, durante o Permo-Carbonífero.

O significado e relevância da primeira questão, no quadro do atual estado da arte da geologia subglacial, deve-se, entre diversos outros fatores, ao ineditismo de algumas das estruturas e feições descritas na área, em se tratando do registro da glaciação gondvânica, em especial o caráter múltiplo de algumas superfícies estriadas (ou seja, estratigraficamente repetidas), contendo evidências de terem sido formadas sobre substrato não consolidado.

A segunda questão deve ser examinada em duas escalas e contextos distintos; primeiramente, tendo em vista a dinâmica sedimentar que caracteriza os diversos subambientes glaciais; e, em segunda, no contexto dos eventos tectônicos que afetaram 
a região do arco de Ponta Grossa no Permo-Carbonífero. Inclui-se no primeiro caso o problema da preservação de superfícies estriadas múltiplas (RochamCampos et al., 1999; no prelo; Trosdtorf Jr. et al., 2001).

Outras questões de Geologia Glacial surgidas no transcorrer da pesquisa, vieram a enriquecer e complementar o levantamento do quadro da glaciação Gondvânica, na região do arco de Ponta Grossa. A primeira refere-se à verificação da existência de excelentes exposições de diamictitos e outras rochas do Subgrupo Itararé, na clássica localidade de Witmarsum, onde se localiza o notável pavimento estriado glacial (Fuck e Bigarella, 1967). Os diamictitos, que correspondem a diversos tipos de tilitos, compõem sucessões semelhantes às que ocorrem no Pleistoceno do Hemisfério Norte (Boulton, 1979; Gowan, 1998), suscitando a elaboração de uma "estratigrafia de tilitos" relacionados à ação do lobo glacial Paraná.

A provável origem glácio-terrestre dos diamictitos sugeridos pelas suas características foi corroborado pela descoberta de estruturas interpretadas como periglaciais e indicativas de presença de solo perenemente congelado na região, durante o neopaleozóico. As sucessões de tilitos, por sua vez, intercalam-se com pacotes arenosos depositados provavelmente em ambiente marinho raso. A estratigrafia glacial e a distribuição dos pavimentos e superfícies glácio-estriados da área sugerem alternância de deposição glácio-terrestre e glácio-marinha, provavelmente associada a fases de avanço e recuo do lobo Paraná.

Tornou-se, portanto, atraente examinar a possibilidade de reconhecer "ciclos estratigráficos" controlados glácio-eustática e isostaticamente e suas possíveis relações com os movimentos tectônicos de maior escala, responsáveis pela complexa história tectono-sedimentar do arco de Ponta Grossa. O estudo das questões acima e dos efeitos da tectônica regional na área exigiram a elaboração de mapa geológico detalhado da área de Witmarsum, à escala de 1:25.000.

Finalmente, a interpretação da natureza das formas de terreno, facies e ambientes sedimentares das rochas glaciogênicas estudadas, fornecem elementos para interpretar a paleogeografia reinante na porção sul do arco de Ponta Grossa, durante a glaciação Gondvânica. A correta interpretação da paisagem glacial da região redunda em uma visão mais abrangente e completa da glaciação permo-carbonífera, não só no flanco sul do arco, mas em toda a Bacia do Paraná.

\section{2 - Objetivos}

Tendo como base os comentários acima, os seguintes objetivos principais nortearam a realização da presente dissertação: 
- a análise e interpretação das formas de terreno erosivas e deposicionais subglaciais do Subgrupo Itararé (neopaleozóico), na parte sul do arco de Ponta Grossa, em termos dos processos subglaciais relacionados à sua formação;

- a caracterização das condições subglaciais do lobo Paraná e interpretação das características da geleira neopaleozóica, com base nas feições analisadas;

- o esclarecimento das condições geológicas (deposicionais e tectônicas) que levaram a preservação e exposição das formas de terreno na área de estudo; e

- a análise da evolução paleoambiental e paleogeográfica da área estudada.

As novas descobertas, referidas anterioremente, ampliaram consideravelmente o projeto de pesquisa, adicionando novos objetivos à dissertação, que incluem os seguintes tópicos:

- caracterização sedimentológica e interpretação do ambiente deposicional dos diamictitos e rochas associadas da área de Witmarsum;

- descrição e interpretação de deformações glaciotectônicas, em especial, morainas de empurrão; $e$

- interpretação e correlação de ciclos estratigráficos do Subgrupo Itararé, na área.

\section{3 - Área de estudo: contexto geológico}

A literatura atualmente existente sobre do Subgrupo Itararé no contexto da Bacia do Paraná é ampla e farta (Maack, 1946; Martin, 1961; 1964; Martin et al., 1960; RochaCampos, 1967; Rocha-Campos et al., 1976; 1977;1988; 2000; Tommasi e Roncarati, 1970; Tommasi, 1973; Schneider et al., 1974; Almeida, 1980; Almeida et al., 1980; Fulfaro et al., 1980; Gravenor e Rocha-Campos, 1983; Tomazelli e Soliani, 1982; França, 1983; Canuto, 1985; Santos, 1987; Santos et al., 1992; 1996; Eyles et al., 1993; Petri e Souza, 1993; d'Avila et al., 1995; Milani, 1997; Castro, 1999 e outros). A revisão da evolução do conhecimento e o atual estado da arte desses tópicos não é objetivo da presente dissertação. O presente capitulo almeja somente situar o leitor no quadro geológico atualmente presente na porção sul do arco de Ponta Grossa e as principais idéias a respeito da evolução geológica da área.

O arco de Ponta Grossa é interpretado como tendo sido gerado principalmente no Mesozóico, associadamente ao vulcanismo básico juro-cretácico. Contudo, diversos autores apontam evidências de comportamento tectônico ativo pré-Mesozóico na região. Mapas de isoespessura total do Subgrupo Itararé (e.g.: Northfleet et al., 1969) ou de intervalos cronoestratigráficos da unidade (Santos, 1987; Santos et al., 1996), por exemplo, delineiam uma área mais elevada situada no local do atual arco. Outros dados, 
entretanto (Daemon e Quadros, 1970; Zalán et al., 1991), mostram que o comportamento tectônico da área pode ter variado de positivo a negativo durante o neopaleozóico. Esse comportamento foi, sem dúvida, um dos principais fatores que controlaram, tanto a subsidência, ocasionando deposição na região do arco, quanto de sua elevação e exposição.

Após o Frasniano (Devoniano Superior), a porção sul do arco de Ponta Grossa, assim como toda a Bacia do Paraná, sofreu movimento epirogênico ascensional que os expôs à erosão. Consequentemente, o limite superior do Grupo Paraná, tanto em superfície, quanto em subsuperfície, é de natureza erosiva (Almeida et al., 1980). A inconformidade angular que separa o Grupo Paraná e o Grupo Tubarão é tênue e indistinta em afloramento, mas bem reconhecivel em âmbito regional.

O hiato perdurou até o Estefaniano (Carbonífero inferior ou médio; Santos et al, 1996). Este longo período de exposição produziu extensa superficie, onde posteriormente se instalou o lobo glacial Paraná (Frakes e Crowell, 1969; Santos, 1987). Na porção sul do arco de Ponta Grossa, essa superfície extremamente plana, apresenta leve basculamento para norte (Northfleet et al, 1969), da ordem de 7' (Canuto, 2001; Canuto et al., 2001).

Uma característica marcante da região é a presença de lineações, correspondentes a falhas SE-NW, que cruzam o arco, e que controlaram grande parte da sedimentação durante o Permo-Carbonífero, condicionando os grandes ciclos sedimentares e estratigráficos (transgressão e regressão) presentes na área (Canuto, 2001; Canuto et al., 2001). (Capitulo V.)

Dentro deste contexto geohistórico, a região sul do arco de Ponta Grossa (Fig. I-1) reúne, pois, condições excepcionais para a realização da pesquisa proposta, pois a natureza provavelmente terrestre e marinho proximal dos depósitos do Subgrupo Itararé, sugerida pela associação com extensos e múltiplos (estratigraficamente repetidos) pavimentos e superfícies estriadas e as próprias características sedimentológicas dos sedimentos, sugere por sua vez, a localização da geleira sobre área emersa, relativamente elevada, em que uma intensa erosão predominou sobre a deposição glacial. 


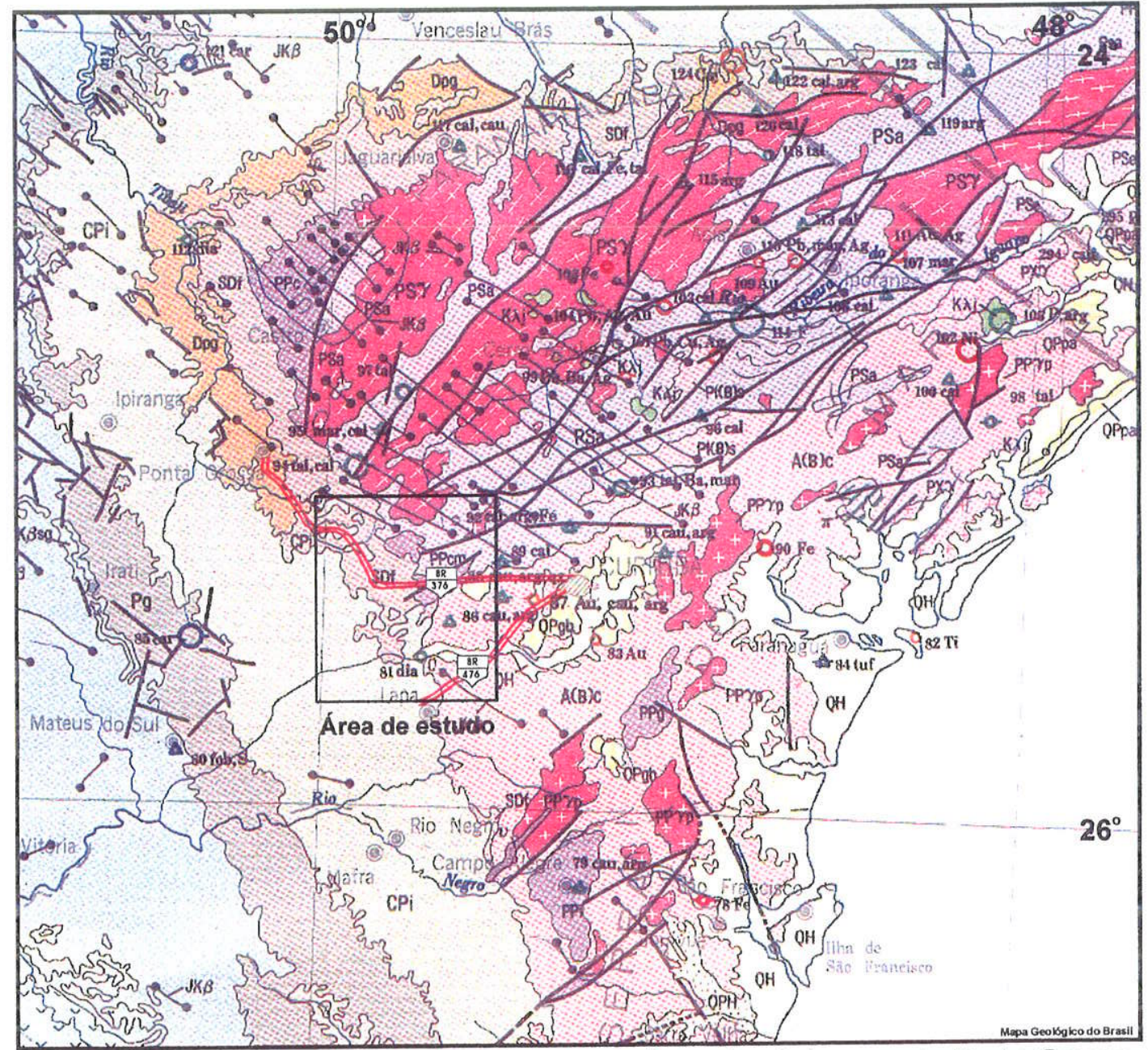

Figura I-1: Localização da área de estudo e geologia regional do arco de Ponta Grossa. Cores avermelhadas e roxas: embasamento Pré-Cambriano; marrom claro: Formação Furnas (SDf); laranja: Formação Ponta Grossa (Dpg); verde claro: Formação Itararé (CPi); verde escuro: Grupo Guatá (Pg); azul: Grupo Passa Dois. Os elementos tectônicos do arco incluem: a) enxame de diques de diabásio, ocupando fraturas de direção SE-NW (linhas finas com círculos pretos); b) grandes lineamentos estruturais de direção SE-NW (linhas grossas cinza); c) falhas de direção SE-NW e SW-NE (linhas pretas). Notar distribuição diferenciada dos diversos elementos estruturais em relação à localização da área estudada (Fonte: Mapa Geológico do Brasil, $1: 2.500 .000)$.

Do ponto de vista da Geologia Glacial neopaleozóica, já destacada anteriormente, a região caracteriza-se pela ocorrência de grande número de afloramentos de rochas estriadas por abrasão glacial sobre arenitos da Formação Furnas (Devoniano) ou sobre diamictito e arenito do próprio Subgrupo Itararé (Fuck e Bigarela, 1967; Bigarella et al., 1967; Canuto, 1985; Santos, 1987; Santos et al., 1996; Rocha-Campos, 1967; RochaCampos et al., 1999; no prelo; Vesely e Assine, 1998; Trosdtorf Jr. et al., 2001). Estrias 
glaciais cobrem descontinuamente uma superficie relativamente plana de aproximadamente de $1.500 \mathrm{~km}^{2}$, abrangendo uma considerável porção do flanco sul (SW) do arco de Ponta Grossa.

Além dos diamictitos, camadas de arenito feldspático com estratificação cruzada e arenitos conglomeráticos, ambos pouco espessos, constituem as litofacies predominantes do Subgrupo ltararé nessa área (Bigarella et al., 1967; Fuck e Bigarella, 1967). Apesar de a maioria das litofacies presentes na área serem de natureza continental ou marinha proximal, na porção mais a oeste da área afloram sedimentos glácio-marinhos relativamente profundos, caracterizados, principalmente, pela ocorrência de folhelhos com clastos caídos, apontando a presença de icebergs.

A ocorrência de estriações glaciais, em dois níveis distintos, sobre o arenito Furnas e diamictito do Subgrupo Itararé, foi atribuída por Bigarella et al. (1967) e Fuck e Bigarella (1967) a duas fases glaciais distintas, denominadas "Glaciação Rio do Salto" e "Glaciação Cancela". Paleocorrentes medidas por Bigarella e Salamuni (1967) em arenitos do Subgrupo Itararé indicam fluxo das correntes no geral de SE-NW, consistentes, com a orientação das estrias glaciais. Igualmente concordantes são os dados de medição da "fabric" dos diamictitos (Bigarella et al., 1967). As paleocorrentes do Subgrupo Itararé diferem das do arenito Furnas, orientadas em média de NE-SW (Fuck e Bigarella, 1967), e permitem, associadamente ao tipo das estruturas sedimentares destes, diferenciá-los dos arenitos do Subgrupo Itararé, aos quais se assemelham.

Novos dados surgidos, altamente relevantes para a melhor compreensão do ambiente glacial da região, foram obtidos por Rocha-Campos et al. (1999; 2001; no prelo) e Vesely e Assine (1998). Os primeiros descrevem afloramento nas imediações de Palmeira (PR), onde foram identificadas de quatro a cinco superficies glacialmente estriadas sobre arenitos do Subgrupo Itararé, estratigraficamente repetidas. Vesely e Assine (op. cit.), referem-se à descoberta de várias superfícies estriadas sobre o arenito Furnas e diamictito do Subgrupo Itararé, na região entre Curitiba e Ponta Grossa. Reconhecem a natureza inconsolidada dos diamictitos do Subgrupo Itararé portadores das estrias, atribuindo essas litologias a tilitos subglaciais.

Com base nos elementos discutidos, é possível, em princípio, comparar o flanco sul do arco de Ponta Grossa a uma região proglacial, envolvendo um ambiente de planície de till (till plain) costeira, baixa, a qual se associam depósitos arenosos e conglomeráticos flúvio-glaciais e glácio-lacustres. A região pode, grosso modo, ter-se comportado analogamente ao escudo canadense sobre o qual se assentou o manto de gelo da Laurêntida, durante o Pleistoceno, constituindo o que se denomina de região driftless, isto é, contendo espessura pequena de drift glacial, em razão de deficiência na 
deposição glacial e predominância de erosão extensiva (Eyles, 1993). Contudo, diferentemente do escudo canadense, onde predominam facies terrestres, a porção sul do arco de Ponta Grossa aponta, como veremos, para um ambiente transicional, denotando alternância de ambientes terrestres (flúvio-glacial, glácio-lacustre, subglacial e outros) e marinho proximal (plataforma marinha rasa).

\subsection{1 - Tectônica Regional}

Estruturas maiores, resultantes de tectônica predominantemente rúptil, incluindo fraturas e falhas, afetam todo o pacote de rochas sedimentares da Formação Furnas e Subgrupo Itararé. Esses elementos fazem parte do arcabouço estrutural do atual arco de Ponta Grossa, cuja fase principal de deformação ocorreu no juro-cretácico.

Na região da Colônia Witmarsum, outras deformações de natureza dúctil e rúptil identificadas, de menor porte, estão confinadas ao pacote rochoso do Subgrupo ltararé e são atribuídas a: i) glaciotectonismo; e ii) colapso por derretimento de gelo. São, pois, tidas como penecontemporâneas à deposição da unidade (Permo-Carbonífero) e serão discutidas posteriormente.

A presente dissertação não visava inicialmente deter-se no exame da tectônica regional, a não ser no que se refere à solução de problemas estratigráficos (estratigrafia glacial) e de preservação geológica de feições subglaciais. A distribuição geograficamente próxima de estruturas resultantes dos dois tipos de deformação e a complexidade destas, exigiram, entretanto, o exame mais detido de algumas ocorrências, visando desenvolver critérios que permitissem a sua discriminação segura. Além de identificar os efeitos da tectônica regional, o estudo permitiu reconhecer estruturas associadas a depósitos e possiveis feições geomórficas de origem glacial.

A análise dos mapas geológicos disponiveis (folhas de Quero-Quero, Porto Amazonas, Campo Largo e Contenda; Fuck et al., 1965; Muratori et al., 1965; Palka et al., 1966; Trein et al., 1965) permite observar que a área da pesquisa foi afetada por dois sistemas de fraturas SE-NW e SW-NE, em parte ortogonais, que controlam a drenagem atual. Diques de diabásio de direção SE-NW (Fuck, 1966) e falhas SE-NW e SW-NE são raras na área.

A principal estrutura presente na região da Colônia Witmarsum (Anexo 1) é a falha Cancela, de direção WSW-ENE, que acompanha o vale do rio de mesmo nome. A falha separa arenitos da Formação Furnas, ao norte, de rochas do Subgrupo Itararé ao sul. Tendo em vista o traçado da estrutura, situada próxima à ocorrência de numerosas feições geomórficas interpretadas como de origem glaciotectônica, um exame mais 
detalhado de alguns dos afloramentos da falha Cancela foi realizado, visando caracterizala estruturalmente.

Análise de fraturas realizada por Tomio (em preparação) em afloramento da Formação Furnas situado junto à Companhia de Laticínios Cancela (Figs. I-2 e I-3) indicou que a rocha foi afetada por um regime compressivo de esforços. Em afloramento situado $100 \mathrm{~m}$ mais a leste, entretanto, o traço do plano de falha é ondulado, variando de vertical a inclinado, com ocorrência de brecha de falha contendo fragmentos angulosos de rochas das unidades paleozóicas da área, e o acavalamento de diamictito do Subgrupo Itararé por arenito da Formação Furnas (Fig. I-4). Sobre o bloco acavalado situa-se o célebre pavimento estriado de Witmarsum. Em outro ponto em que o plano de falha foi examinado, pouco a leste do pavimento estriado de Witmarsum, mostra-se ele vertical, exibindo estruturas indicativas de caráter transcorrente e movimentação destral (Fig. I-5).

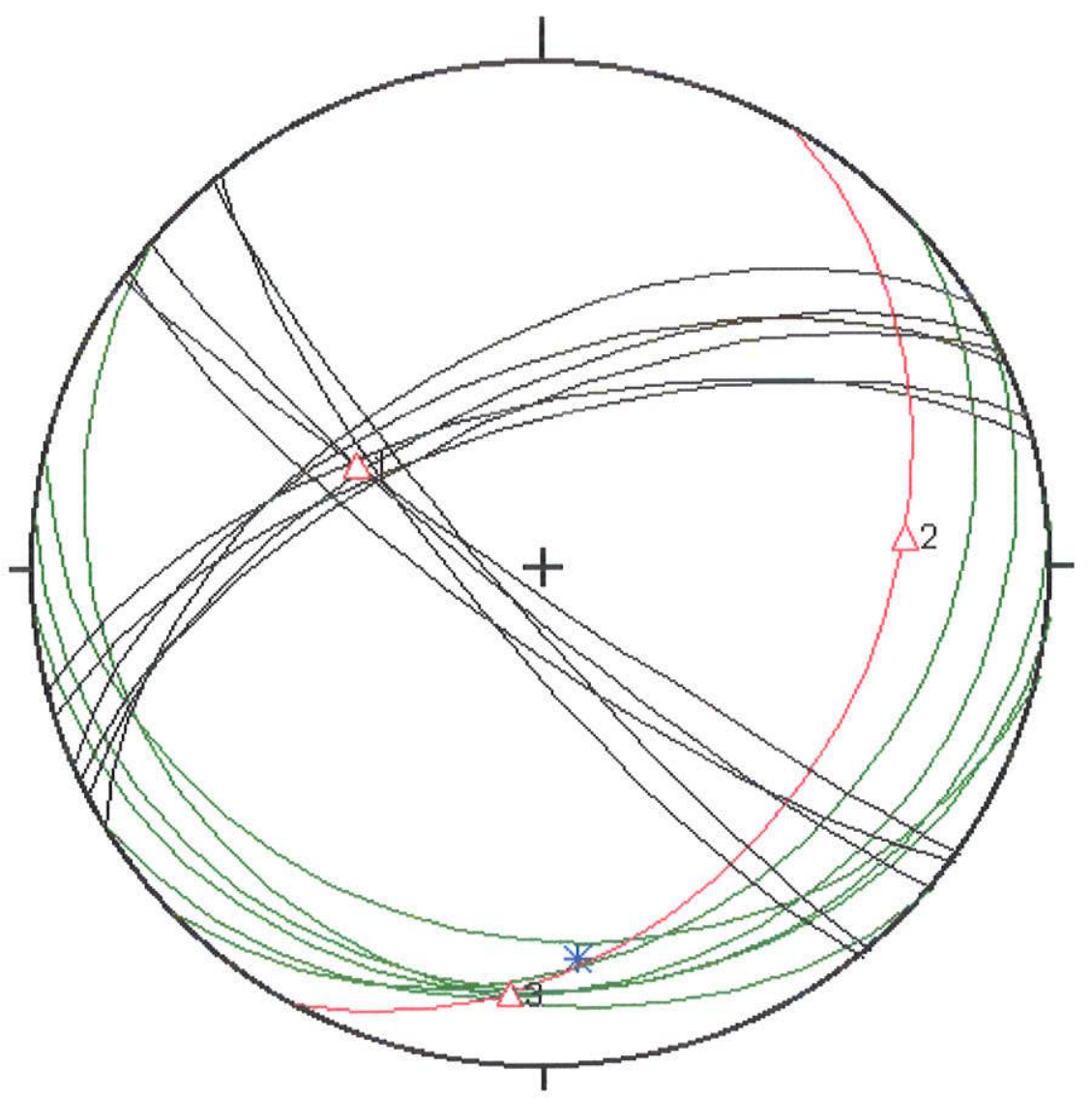

Figura 1-2: Estereograma mostrando regime compressivo de esforços que afetaram a Formação Furnas. Afloramento junto à Companhia de Laticínios Cancela Linhas em preto: fraturas, linhas em verde: acamadamento; linha em vermelho: plano calculado pelos eigen vectors (A. Tomio, em preparação). 

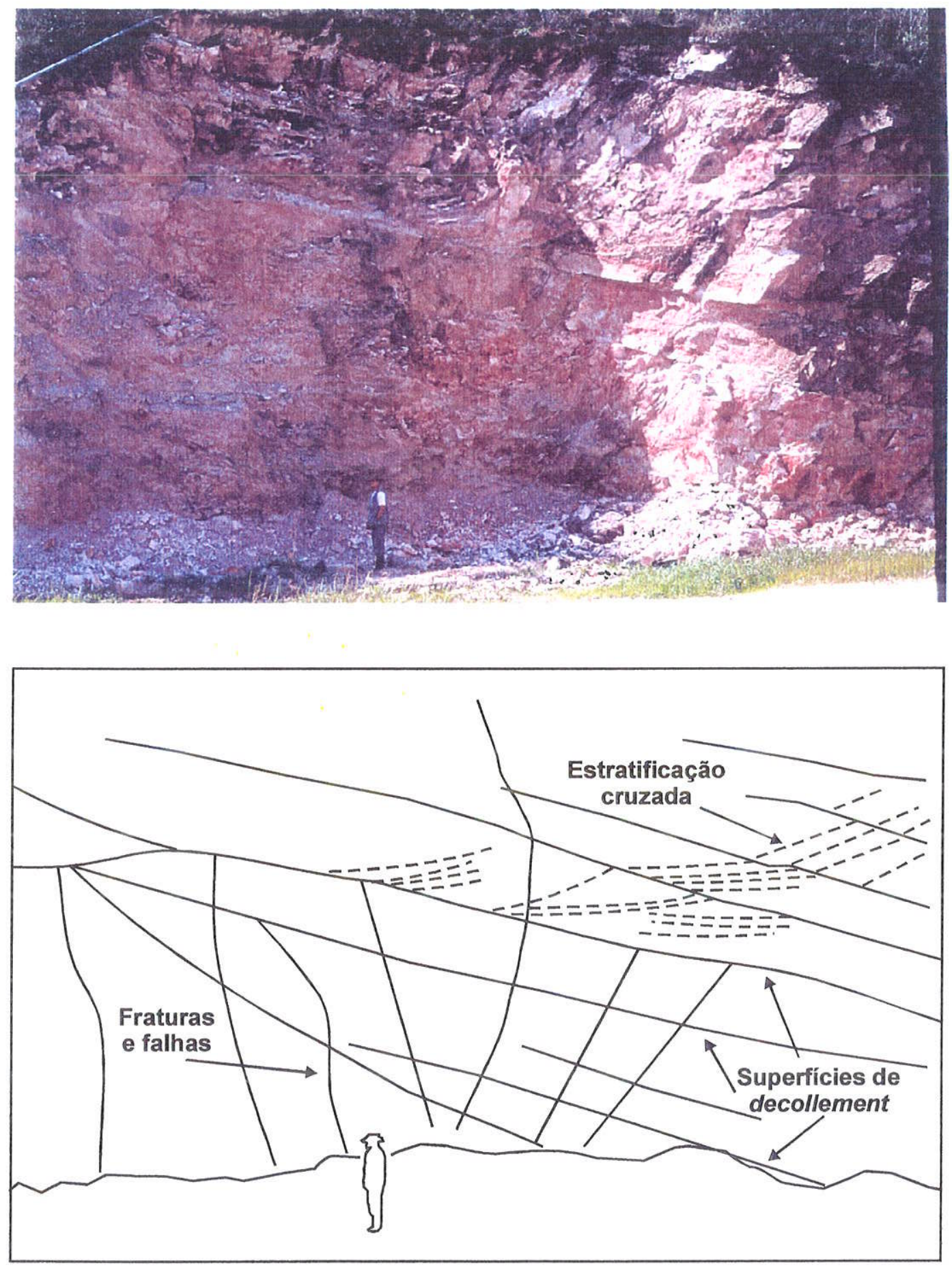

Figura 1-3: Paredão atrás da Companhia de Laticínios Cancela mostrando arenitos da Formação Furnas intensamente fraturados por regime compressivo de esforços relacionado ao falhamento Cancela. No contato entre as camadas observa-se material silto-argiloso, que provavelmente serviu de superfície de decollement (A. Tomio, em preparação). 


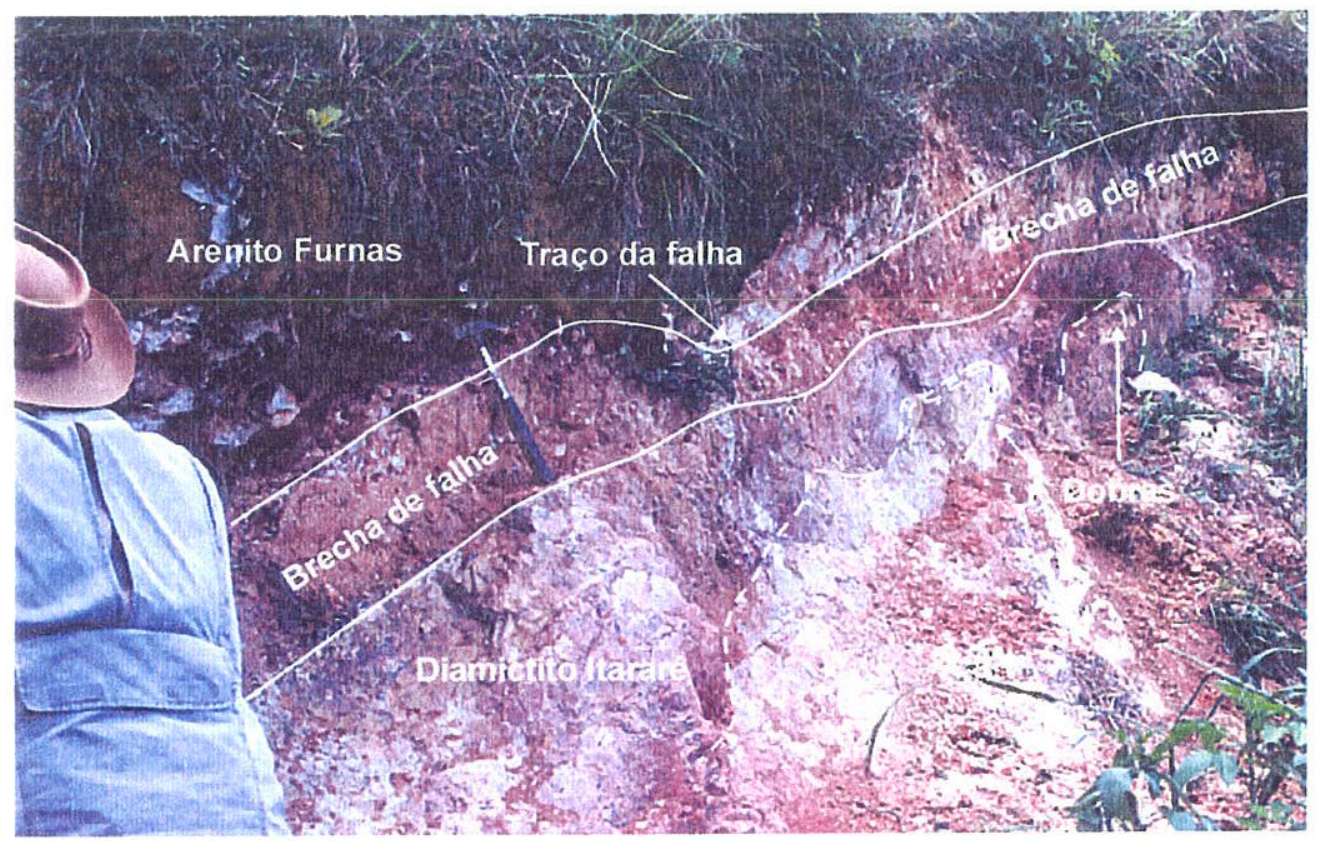

Figura 11-4: Brecha de falha produzida pelo falha Cancela. A falha, que apresenta componente reversa, cavalga arenitos da Formação Furnas sobre sedimentos do Subgrupo Itararé. Notar dobras de arrasto produzidas pela movimentação dos blocos. Essas feições só ocorrem associadas ao plano de falha, cuja atitude neste ponto é $\mathrm{N} 55^{\circ} \mathrm{E} / 60^{\circ} \mathrm{NW}$ (A. Tomio em preparação).

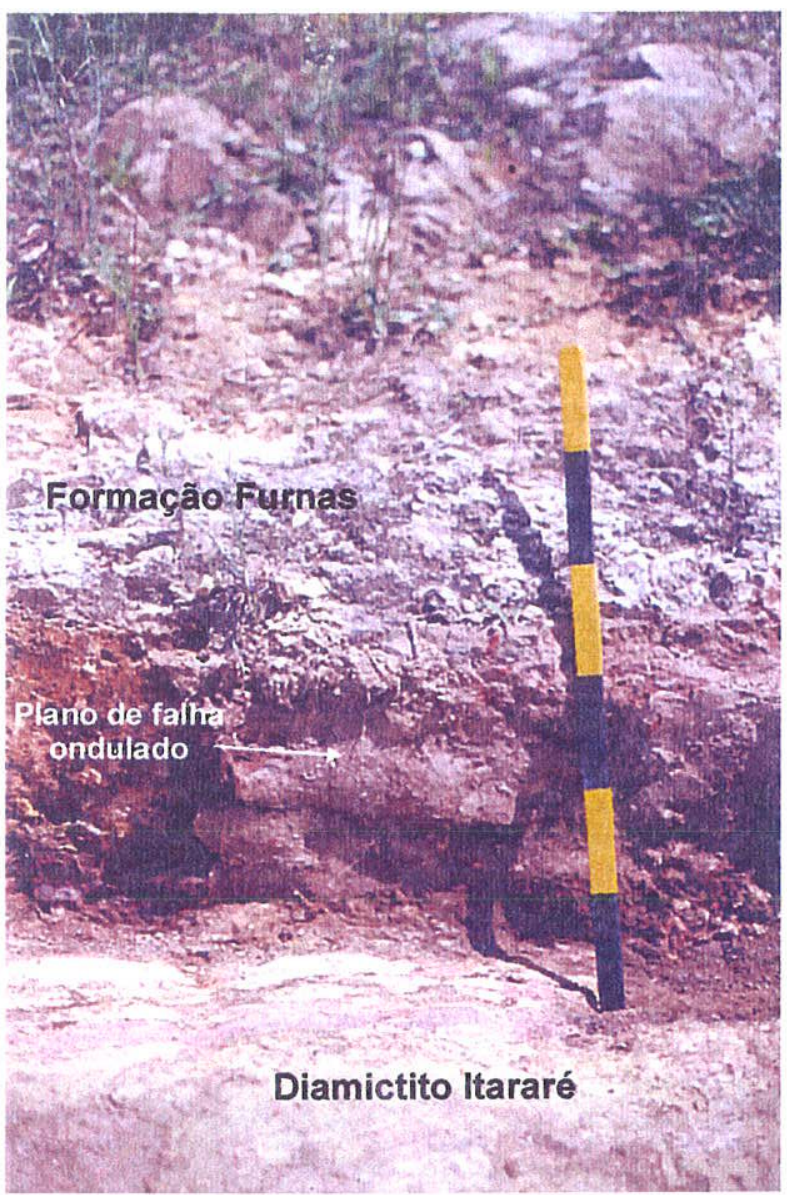

Figura 1-5: Plano de falha subvertical. Notar superfície ondulada, sugerindo uma componente horizontal (transcorrência) importante. A falha coloca em contato lateral os arenitos da Formação Furnas e os sedimentos do Subgrupo Itararé $(100 \mathrm{~m}$ a leste do pavimento estriado de Witmarsum, Anexo 1). 
Situação tectônica ainda mais complexa é mostrada no afloramento situado na Fazenda Schroeder, a cerca de $1,5 \mathrm{~km}$ a oeste do primeiro. Neste local, uma série de falhas reversas corta a Formação Furnas provocando repetição estrutural de exposição do pavimento estriado e novamente acavalamento de diamictito do Subgrupo Itararé por arenito devoniano (Figs. I-6 e l-7).

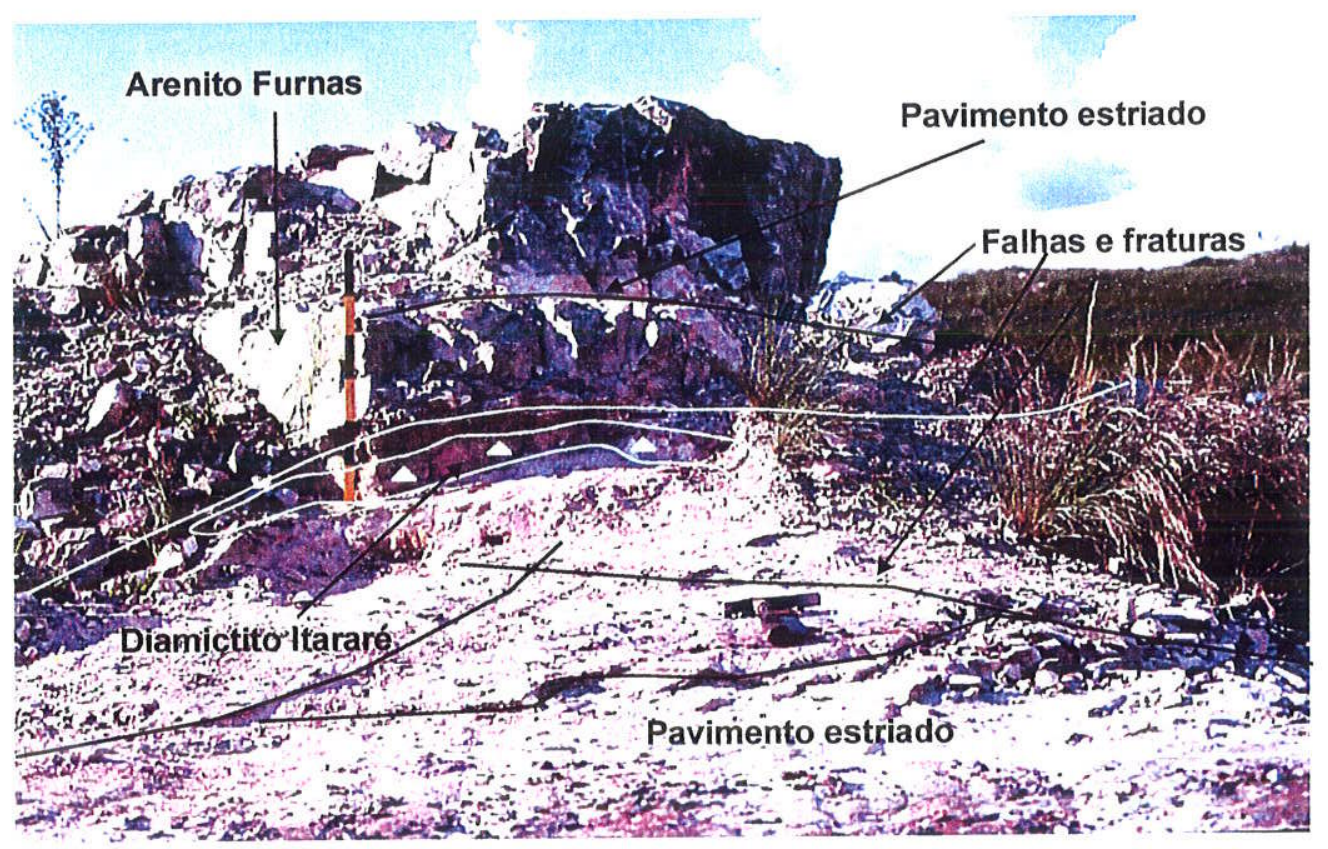

Figura 1-6: Arenito Furnas cavalgando diamictito Itararé. Notar que o pavimento estriado e sulcado, na posição do martelo, está deslocado pelas diversas falhas que passam pelo afloramento (Fazenda Schroeder, Anexo 1).

Segundo Zalán et al. (1990), estruturas relacionadas a movimentações transcorrentes são muito comuns ao longo dos alinhamentos de direção NE e NW presentes na Bacia do Paraná, e associadas, principalmente, as zonas de falha de Guapiara, Curitiba-Maringá, Taxaquara e Lancinha-Cubatão.

Em trabalhos de campo, os autores supra citados identificaram, basicamente, dois principais estilos estruturais presentes na Bacia: a) deformações associadas às intrusões ígneas; e b) deformações associadas às reativações dos grandes lineamentos. Os primeiros foram descritos em Zalán et al. (1985), enquanto que as deformações associadas aos lineamentos NW e NE consistem basicamente de estruturas em flor, dobras e falhas reversas escalonadas ou grandes falhas normais.

Em termos regionais, a falha Cancela corresponde a uma extensão da Zona de Falha Lancinha-Cubatão (Fig. I-8). Hasui e Oliveira (1984), a denominam de Zona de 
Cisalhamento de São Paulo, que se caracteriza pela presença de ultramilonitos e protomilonitos, às vezes com quartzo e mica recristalizados. Segundo os autores, essas falhas são tardibrasilianas, pois seccionam unidades dobradas e metamorfizadas do Proterozóico Superior. A distribuição das falhas transcorrentes no embasamento não é uniforme, mas compõem feixes de descontinuidades sub-paralelas e obliquas, anastomosantes ou não, de tal modo que eles, por sua vez, repetem a estruturação em blocos na escala regional.

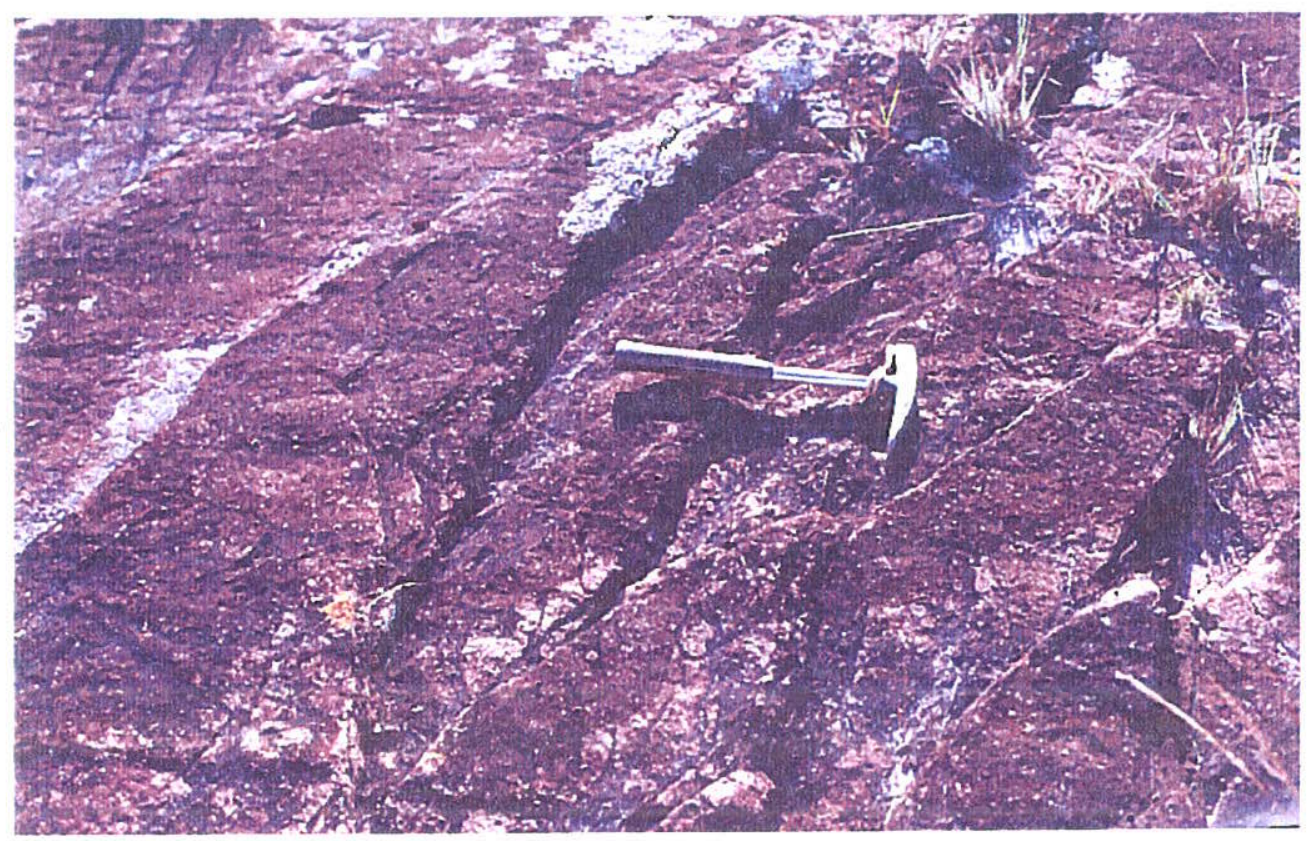

Figura 1-7: Pavimento estriado cortado pela falha Cancela. Notar degraus causados pela falha (Fazenda Schroeder, Anexo 1).

Segundo Campanha (1991), numa visão ampla, a geologia da região do alto e médio Vale do Ribeira em São Paulo e no Paraná, é caracterizada por um conjunto de rochas supracrustais, de grau metamórfico baixo a médio, classicamente denominado de Grupo Açungui. O embasamento seria constituído por um conjunto de rochas gnáissicomigmatíticas, com alguns núcleos charnockíticos maiores e intercalações variadas de metassedimentos.

Ainda de acordo com o mesmo autor, o Lineamento de Lancinha-Itapeúna (ramo sul do Lineamento de Lancinha-Cubatão) apresenta-se como um fotolineamento estreito, balizado em algumas localidades por brechas cataclásticas, raramente milonitos. $O$ lineamento é tido como de natureza transcorrente destral, que coincide com a movimentação deduzida para a falha Cancela em Witmarsum. 


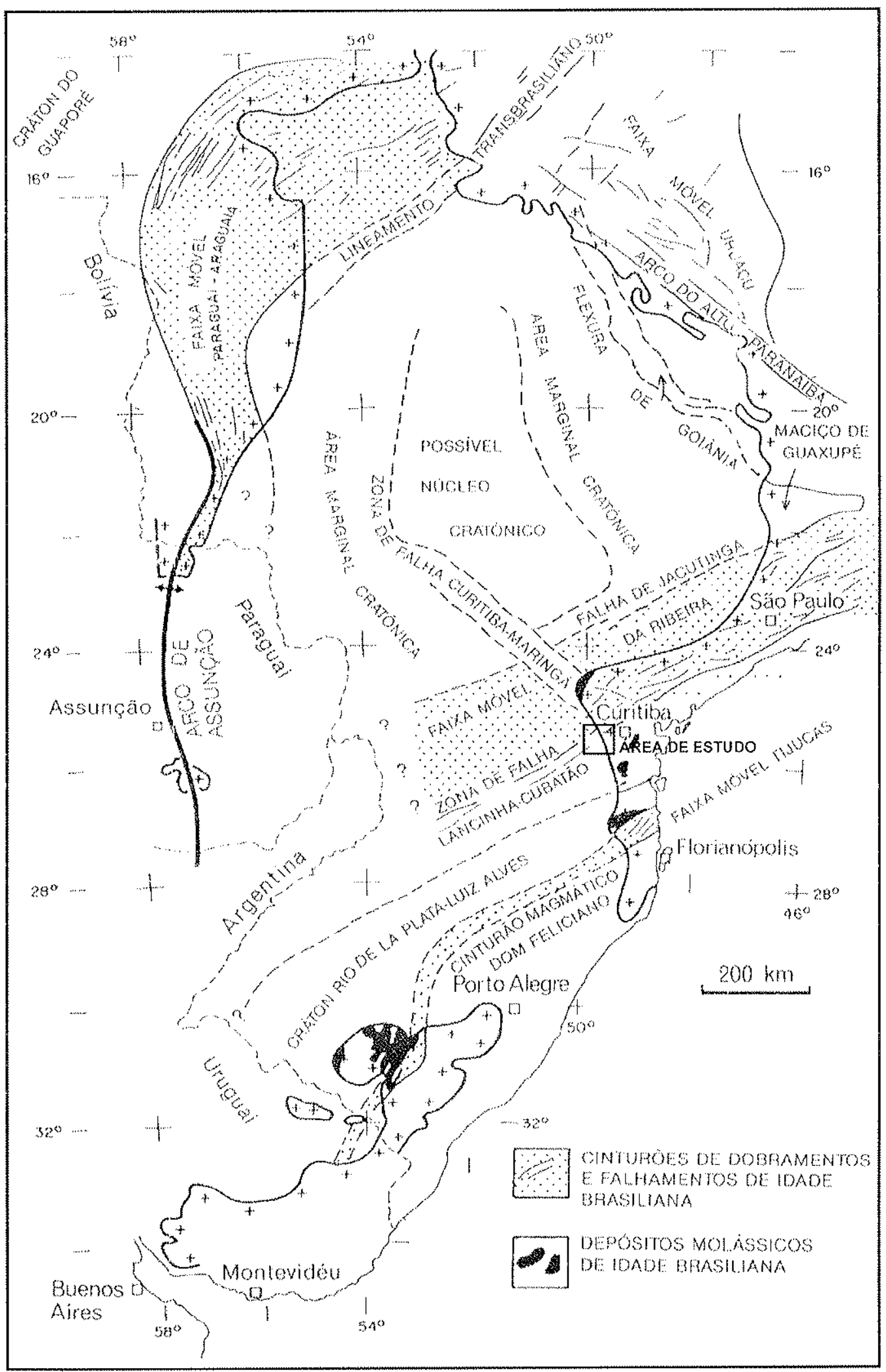

Figura 1-8: Geologia do embasamento da Bacia do Paraná (Zalán et al. , 1990). Notar distribuição da zona de falha Lancinha-Cubatão em relação à área de estudo. 
Outra questão ainda não inteiramente resolvida é a idade do falhamento Cancela. Pode-se afirmar que se trata de um evento pós-Itararé, pois apresenta brecha formada tanto por fragmentos da Formação Furnas, quanto do Subgrupo Itararé. Uma idade associada a ruptura do Gondvana no Mesozóico pode ser descartada, pois segundo Zalán et al. (1990), os lineamentos de direção NE não foram acionados neste evento. Outra possibilidade é de o falhamento ter ocorrido no Terciário, associado à formação das bacias do Rift Continental do Sudeste do Brasil (bacias de São Paulo, Taubaté, Resende e outras; Fig. I-9; Riccomini, 1989).

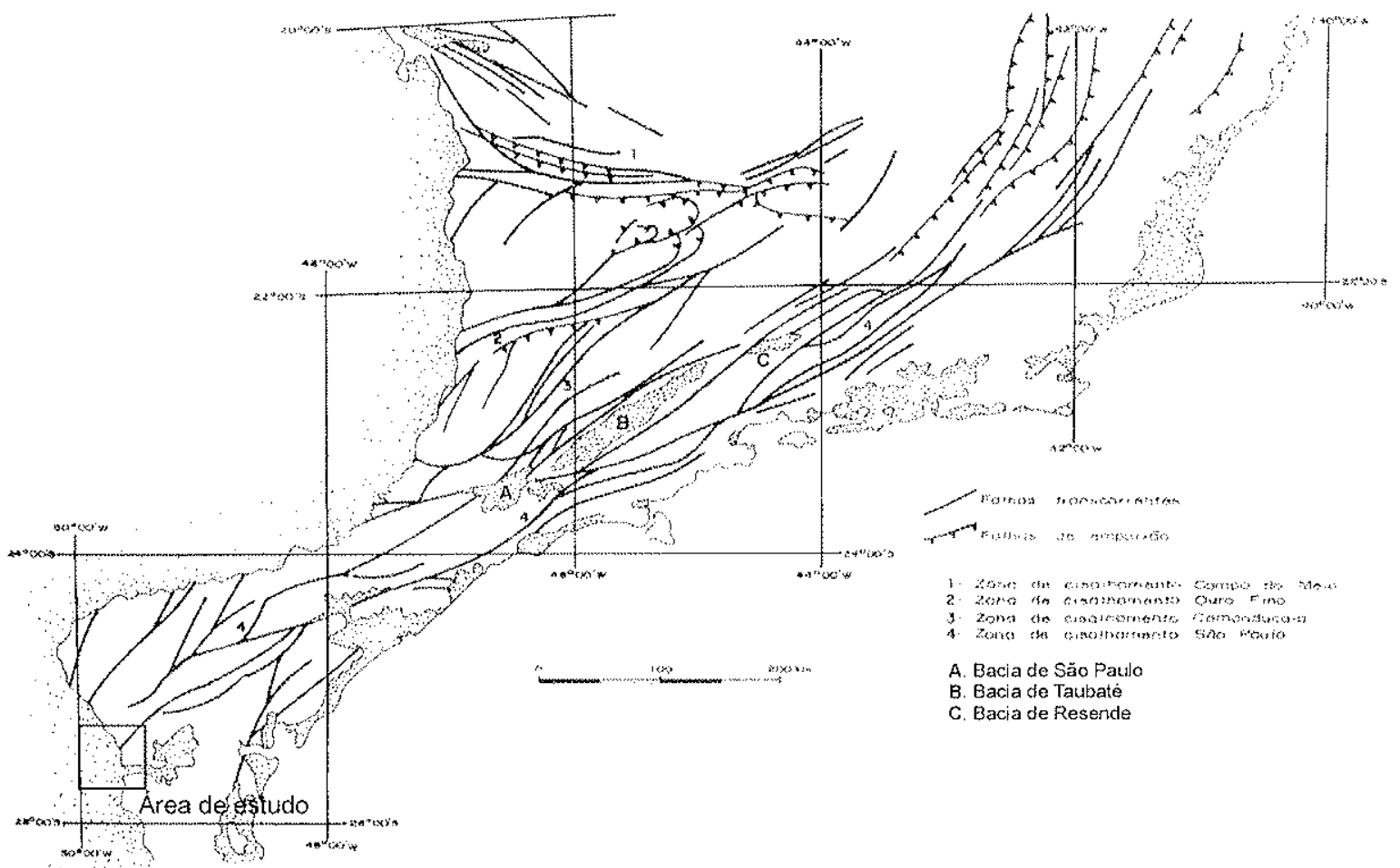

Figura 1.9: Mapa com as principais zonas de cisalhamento da Província Mantiqueira. Notar relação das zonas de cisalhamento com as bacias de São Paulo, Taubaté e Resende, associadas ao Rift Continental do Sudeste do Brasil (modificado de Hasui e Oliveira, 1984).

\section{4 - Métodos}

As atividades desenvolvidas durante a realização desta dissertação foram divididas em três grandes blocos: trabalhos de escritório, de laboratório e de campo, os quais são descritos a seguir: 
Trabalhos de escritório

A pesquisa bibliográfica, dentre as atividades desenvolvidas em escritório, visou ampliar a base de referências especializadas sobre os tópicos da pesquisa, principalmente as novas publicações surgidas no periodo. Além de dados sobre direções de estrias, granulométricos, estratigráficos, mapas de isoespessura da área etc., a pesquisa envolveu consulta a uma ampla gama de publicações especializadas sobre Geologia Glacial e Glaciologia.

A fotointerpretação foi utilizada tanto antes dos trabalhos de campo para localizar novos afloramentos e possiveis feições morfológicas glaciais preservadas, como após estes para detalhar a geologia e feições observadas em campo e planejar as próximas atividades. Esta técnica também foi importante na elaboração do mapa geológica de Witmarsum, apresentado nesta dissertação.

Também foram tratados os dados de paleocorrente, através dos programas TectonicsTF 1.6.1157-DEM e Quickplot, análise granulométrica por diagrama triangular (TriDraw 2.9) e calculados os parâmetros estatísticos pelo método dos momentos de Pearson (Momento4). Além destes, realizou-se a confecção de painéis, o empilhamento de seções estratigráficas levantadas em campo e cálculo das curvas de subsidência do Subgrupo Itararé através da manipulação de poços profundos e mapas de isoespessura.

\section{Trabalhos de laboratório}

Os trabalhos de laboratório consistiram na execução de diversas análises, tais como:

i) análise granulométrica de amostras coletadas, principalmente, nas regiões de Witmarsum e Palmeira, através de método já consagrado na área (pipetagem e peneiramento);

ii) descrição de seções delgadas; $e$

iii) microscopia eletrônica de varredura (SEM-IDS) para siltito maciço amostrado em Witmarsum.

\section{Trabalhos de campo}

Os trabalhos de campo visaram, em um primeiro momento, o reconhecimento da geologia da área estudada e seus principais aspectos faciológicos e estratigráficos. No estudo dos afloramentos visitados utilizou-se a metodologia clássica de análise de facies, conforme descrita por Walker (1992). Além da coleta de amostras para estudos laboratoriais, também foram obtidas medidas complementares de paleocorrentes (estratificação cruzada acanalada, tabular, marcas onduladas, direções de estrias glaciais 
e cristas de tilito), visando obter um quadro mais completo da paleodrenagem e do fluxo do gelo na regiâo.

Também foram levantadas seções estratigráficas e elaborado um programa de mapeamento nas proximidades da Colônia Menonita de Witmarsum (PR), em escala de semi-detalhe 1:25.000. Como resultado desse trabalho, numerosas ocorrencias de diamictitos, de feições e estruturas associadas, bem como de estruturas atribuídas à tectônica regional foram identificadas e discriminadas, o que enriqueceu e valorizou sobremaneira a dissertação aqui apresentada. 


\section{II - SEDIMENTAÇÃO E EROSÃO SUBGLACIAL: FUNDAMENTOS TEÓRICOS}

No sentido de colocar as questões enfocadas na presente dissertação dentro de um quadro conceitual mais claro, torna-se pertinente apresentar abaixo um resumo da problemática de geologia glacial envolvida na atual pesquisa.

Diversos fatores influenciam nos tipos de interação existentes entre uma geleira e seu substrato. Entre eles podemos citar os regimes térmico e hidrológico e a reologia do substrato sobre o qual a geleira se assenta, fatores que também influenciam os processos e mecanismos de erosão e deposição subglacial.

\section{Regime Térmico}

As geleiras podem ser classificadas, quanto ao seu regime térmico, como temperadas, subpolares e polares. Segundo Rocha-Campos e Santos (2001), a distribuição da temperatura no gelo é função da troca de calor gerado na superfície, internamente e na base da geleira. Dependendo das condições impostas ao fluxo térmico da geleira, teremos a ocorrência de gelo frio e/ou gelo quente. No primeiro caso, a temperatura do gelo está abaixo do ponto de fusão por pressão e, no segundo, encontrase próximo ou acima deste.

O regime térmico basal das geleiras tem grande importância para a dinâmica da geleira e os depósitos relacionados a ela. São reconhecidas três condições térmicas basais para uma geleira: a) base fria ou seca, onde predomina o congelamento, não havendo, portanto, água de degelo e as geleiras estão aderidas ao substrato; b) base quente ou úmida, onde predomina fusão, formando-se água de degelo na base da geleira, estando, portanto, a mesma desligada do seu substrato; e c) a terceira condição seria intermediária, onde ocorreria tanto congelamento, como degelo basal.

O regime térmico basal de uma geleira tem conseqüência direta sobre o seu comportamento dinâmico, particularmente nos mecanismos de fluxo do gelo, e os efeitos destes sobre os diferentes substratos sobre os quais as geleiras se movimentam, que ainda irão controlar a ocorrência e a intensidade dos processos erosivos e deposicionais subglaciais.

O fluxo de uma geleira de base fria ocorre por deformação interna, o que envolve o deslocamento relativo dos cristais de gelo; em uma geleira de base quente o fluxo se dá, além da deformação interna, por deslizamento basal, que é causado pela presença de um filme d'água entre o gelo e o substrato, e se o substrato for constituído de material deformável (sedimento inconsolidado), teremos o fluxo da geleira favorecido pela deformação do substrato (Fig. II-1). 

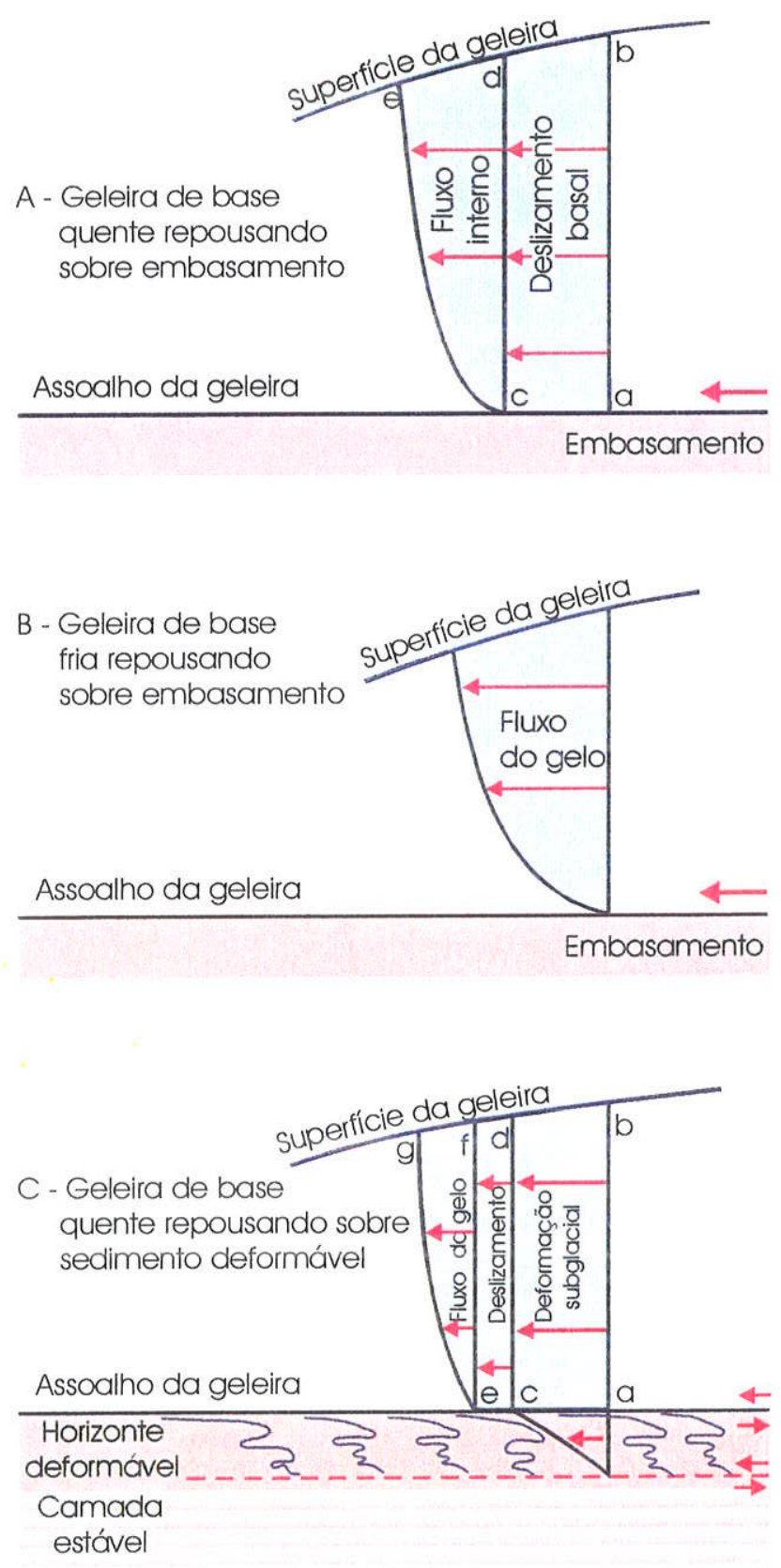

Figura II-1: Distribuição da velocidade de fluxo do gelo em geleiras de diferentes regimes térmicos basais. O deslocamento ocorre pela soma de deslizamento basal e deformação interna do gelo em (A); só deformação interna em (B); e soma de deformação subglacial, deslizamento basal e deformação interna em (C). Figura extraída de Rocha-Campos e Santos (2001).

O regime termal de uma geleira também pode variar espacialmente. A Figura II-2 mostra a combinação de três zonas termais dentro da mesma geleira. Ela pode ser entendida como a passagem contínua entre condições térmicas de gelo frio e quente (Fig. II-2 A - E). Na condição A ocorre derretimento basal do gelo (gelo quente). Neste caso o calor gerado na base da geleira é maior do que pode ser removido por condução 
ao gradiente de temperatura. A condição $\mathbf{B}$ representa uma zona de equilíbrio entre derretimento e congelamento. Neste caso o calor gerado na base da geleira é igualmente conduzido ao longo da direção do gradiente de temperatura. $\mathrm{Na}$ condição $\mathrm{C}$ ocorre congelamento (gelo frio). Neste caso, o calor gerado na base da geleira é rapidamente retirado da camada basal, a qual o gelo então adere.

Na Figura II-2 A ocorre uma situação limite, predominando a condição $C$, onde o substrato está congelado (permafrost), não ocorrendo, pois, deslizamento basal. No próximo diagrama, na porção central não há predomínio de derretimento e nem de congelamento (condição $B$ ). Ocorre aí deslizamento, resultando em grandes zonas compressivas na margem da geleira. A Figura II-2 C mostra um cenário mais complexo de regime térmico, no qual o centro da capa de gelo experimenta derretimento basal. A água de degelo percola em direção à margem da geleira, resfriando-se na zona intermediaria onde novo gelo basal é formado (regelamento). As Figuras II-2 D e E mostrarn outro extremo, onde há predomínio de derretimento basal (gelo quente, condição A).

A

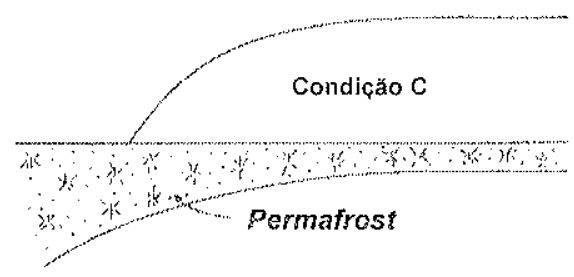

C

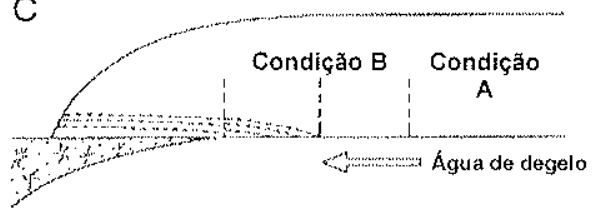

B
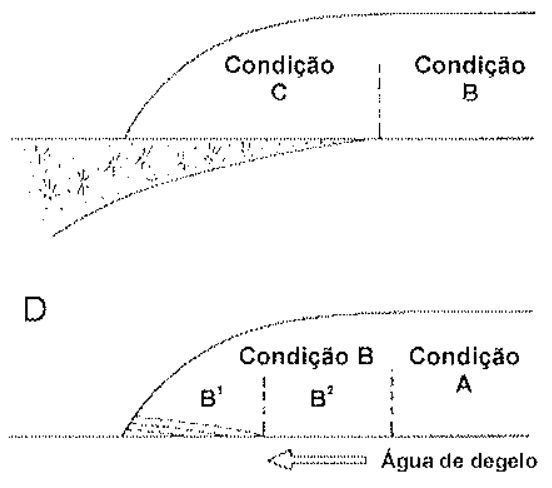

$E$ Condiçăo A

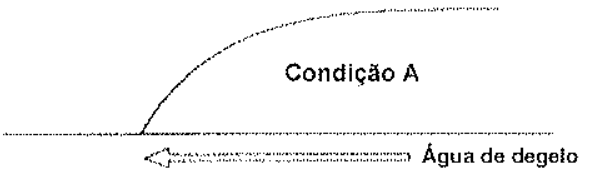

Figura II-2: Diagrama esquemático ilustrando os diferentes cenários possiveis para o regime termal basal coexistindo dentro da mesma geleira. Condição $A=$ quente; Condição $B=$ equilíbrio termal; Condição $C$ = frio. Modificado de Bennet e Glasser (1996).

$\mathrm{Na}$ prática, o cenário ou ordem desses limites ou fronteiras termais dentro da geleira pode variar drasticamente. Por exemplo, irregularidades do substrato ou tipos climáticos diferentes a qual a geleira está exposta produz cenários locais mais 
complexos. A Figura II-3 A mostra uma seção esquemática de uma grande capa de gelo que se extende desde latitudes polares a médias. Neste caso, o regime termal é controlado primeiramente pelo efeito da espessura da capa de gelo e pelo clima. A variação climática da capa de gelo resulta em contraste entre as margens norte e sul; entre condições de clima continental frio e marinho quente, respectivamente. A Figura II-3 B mostra como a presença de uma camada deformável pode ser afetada apenas onde a geleira possui base quente. Este cenário pode ser complicado pela introdução da topografia basal (Fig. II-3 C).

A

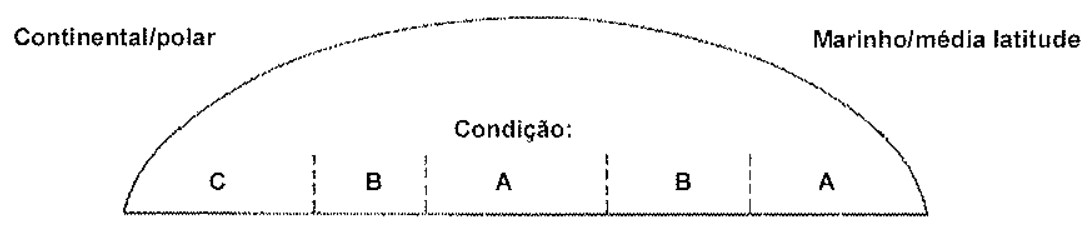

B

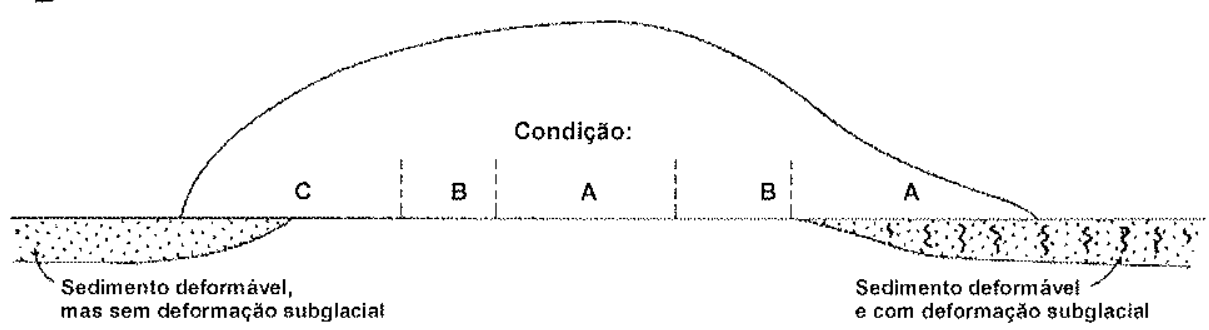

C

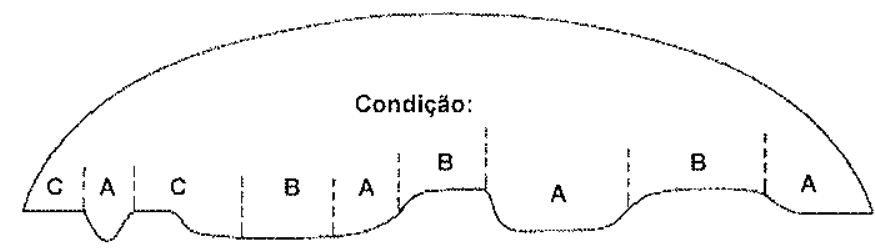

Figura II-3: Seção esquemática de três capas de gelo mostrando cenários de regime termal basal distintos e o papel do clima e da topografia do substrato modificando este cenário. Condição $A=$ quente; Condição $B$ = equilíbrio termal; Condição $C$ = frio. Modificado de Bennet e Glasser (1996).

Da mesma maneira que a temperatura de uma geleira pode variar espacialmente, ela pode também variar com o tempo, pois o regime termal basal dentro de uma capa de gelo não é estático. Dois fatores principais controlam essa variação: a) o aumento do 
calor causado pela fricção do gelo com o substrato; e b) resfriamento ocasionado pela advecção $^{2}$ na parte central da capa de gelo que permanece frio.

Em escalas muito pequenas o regime termal basal e, em particular, os limites entre as zonas termais podem mudar como resultado de flutuações locais e regionais: (1) velocidade do gelo; (2) acumulação; (3) fluxo de calor geotermal; e (4) espessura do gelo. Em larga escala de tempo, a erosão glacial pode modificar a topografia basal, causando variações no regime termal.

\section{Regime Hidrológico}

A água de degelo glacial possui um importante papel em muitas geleiras, pois: (1) é o principal produto da ablação; (2) está intimamente envolvida no deslizamento da geleira; e (3) é responsável pela remoção de detritos na interface gelo-rocha e seu transporte além dos limites da geleira. $O$ derretimento ocorre quando há calor suficiente para o gelo tornar-se água. O calor pode ser suprido pela: (1) radiação solar; (2) fricção devido ao fluxo do gelo, e (3) calor derivado da crosta terrestre abaixo da geleira (calor geotérmico).

A drenagem da água de degelo glacial dá-se principalmente por uma rede de canais e túneis. O tipo de sistema de canais dentro de uma geleira depende primariamente de seu regime termal. Uma geleira consistindo de gelo frio não permitirá que a água de degelo penetre, tendendo a ficar confinada na superfície da geleira. Em uma geleira de gelo quente, a água pode penetrar através da massa de gelo e o fluxo d'água ocorrerá através de canais supraglaciais (superfície), englaciais (dentro) e subglaciais (entre a geleira e o substrato).

Canais supraglaciais tendem a terem poucos metros de largura e exploram fraquezas estruturais do gelo. Em planta eles podem adotar um curso meandrante ou entrelaçado. A velocidade dentro desses canais é normalmente alta devido à sua superfície lisa. Em gelo quente, canais supraglaciais são normalmente pequenos e são interrompidos por poços verticais (vertical shafts) que desviam a água para dentro da geleira. Esses poços podem ser simplesmente crevasses ou, alternativamente, eles podem ser túneis verticais cilindricos, chamados de moulins.

Segundo Holmlund (1988) a geometria interna de moulins pode ser estudada em detalhe na Storglaciären na Suécia. O mapeamento detalhado da superfície desta geleira mostrou que os moulins exploraram antigas crevasses.

\footnotetext{
2 Advecção é a transferência de calor (energia) em uma direção horizontal ou vertical por movimentação do gelo ou da neve (Bennet e Glasser, 1996, pg. 44).
} 
Com a movimentação do gelo ocorrem mudanças no campo de esforços da geleira, podendo causar a abertura, aprofundamento ou fechamento de crevasses. Quando a crevasse fica preenchida por água, esta pode se aprofundar suficientemente para interceptar a drenagem englacial e condicionar o fluxo de água de degelo da geleira. Quando o fluxo da geleira move a crevasse para dentro de uma zona de compressão, a crevasse pode fechar, mas o calor transportado pela água de degelo pode fazer com que o canal de drenagem permaneça aberto e deste modo formar um moulin.

Os moulins de Storglaciären consistem de poços praticamente verticais de 30-40 $m$ de profundidade, os quais alimentam túneis englaciais que descem da base do moulin em ângulo entre $0^{\circ}$ e $45^{\circ}$. A orientação desses túneis englaciais é fortemente controlada pela orientação da crevasse original que formou o moulin.

Os moulins integram uma rede de canais e túneis. A orientação dessa rede é controlada pela pressão do gradiente d'água dentro da geleira. A água flui dos pontos de alta pressão para os de baixa. A Figura II-4 mostra uma situação hipotética, de um tubo preenchido por água dentro de uma geleira. O peso do gelo acima do ponto A é igual à pressão d'água da coluna $B C$. A linha entre $A$ e $C$ define a superfície de igual pressão potencial. Ao longo desta linha, a pressão devida ao peso do gelo acima é igual à pressão d'água gerada. Se movêssemos o tubo para a direita, o peso do gelo sobre o ponto $A$ diminuiria, consequentemente a coluna d'água $B C$ iria diminuir e uma nova superficie equipotencial poderia ser definida (Bennet e Glasser, 1996). Sendo assim, o fluxo d'água será de uma superfície equipotencial de alta pressão para uma de menor. Por conseqüência, os condutos e túneis englaciais serão orientados perpendicularmente as linhas de equipotenciais (Fig. II-5).

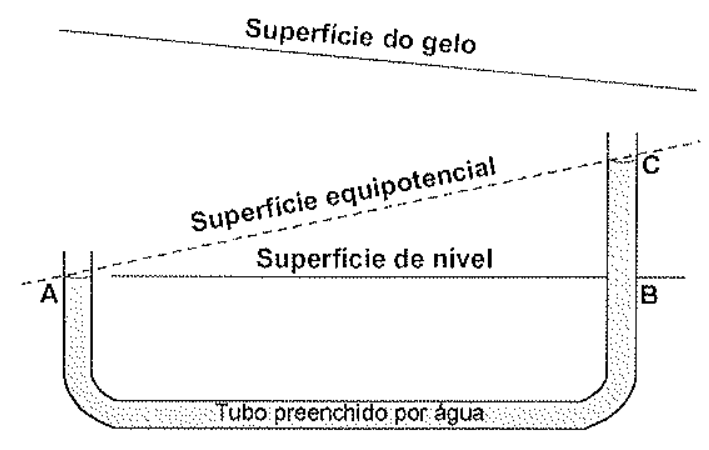

Figura II-4: Diagrama ilustrando uma situação hipotética de um tubo preenchido por água dentro de uma geleira e seu potencial hidráulico. A pressão exercida pelo peso do gelo acima do ponto $\mathrm{A}$ é igual à pressão d'água da coluna $\mathrm{BC}$. O fluxo de água será sempre de uma superfície equipotencial de maior pressão para uma de menor. Modificado de Bennet e Glasser, 1996. 
Completando este quadro (regime hidrológico) estão os canais subglaciais. Os canais subglaciais podem escavar tanto o gelo situado acima (Röthlisberger ou canaisR) como o substrato (Nye ou canais-N). No caso dos canais $\mathrm{R}$ sua direção será determinada pelo gradiente de pressão de água, enquanto que os canais- $\mathrm{N}$ podem explorar fraquezas do substrato.

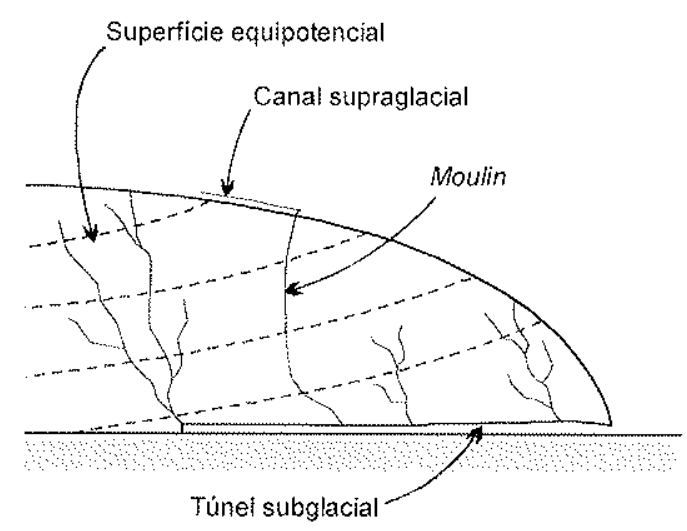

Figura II-5: Superficies equipotenciais de uma geleira (linhas interrompidas, superficies de igual potencial hidráulico). A água sempre flui de áreas de alto potencial para áreas de baixo potencial. Notar altos ângulos dos túneis e canais englaciais em relação às superfícies equipotenciais. $O$ moulin que captura canal supraglacial, extendendo-se até a base da geleira, sendo por sua vez capturado por um túnel subglacial. Modificado de Bennet e Glasser, 1996

No geral, a drenagem glacial abaixo de uma geleira fluindo sobre substrato consolidado, pode apresentar dois tipos de sistemas de canais, que coexistem: canais e cavidades interligadas. O primeiro pode constituir uma série de grandes canais, que descarregam a maior parte do fluxo da água de degelo. O número de seus canais decresce em direção a margem do gelo onde as descargas comumente ocorrem através de um único canal. O segundo, em adição a essa rede de canais, pode drenar a água de degelo por uma série de cavidades subglaciais interligadas (Fig. II 6).

Outro aspecto importante do regime hidrológico são as flutuações na descarga de água de degelo. Essas flutuações podem variar drasticamente tanto diariamente, quanto sazonalmente. As variações quotidianas refletem a temperatura atmosférica e, portanto, 0 cenário diário da ablação da geleira. As descargas são normalmente baixas no início da manhã e aumentam até o final da tarde. Essa flutuação é suprimida no inverno, mas aumenta com a chegada do verão, quando a taxa de ablação diária atinge seu máximo. 


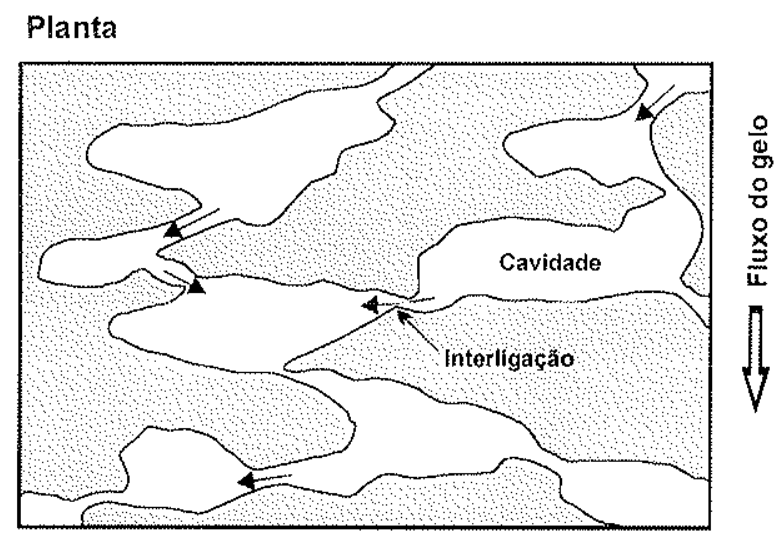

Figura 11-6: Esquema em planta de uma rede de cavidades interligadas. Notar que o fluxo da água dentro dessas cavidades acompanha, grosso modo, o fluxo do gelo. Modificado de Bennet e Glasser, 1996.

As flutuações sazonais são igualmente dramáticas e refletem dois fatores: (1) a natureza sazonal da ablação; e (2) o desenvolvimento sazonal da rede de drenagem interna de geleiras de base quente.

Em algumas geleiras essas flutuações diárias e sazonais são interrompidas por eventos catastróficos, chamados jökulhlaups. Esses são eventos de alta magnitude, normalmente de várias ordens de magnitude acima do pico normal do fluxo de água. Jökulhlaps podem ocorrer devido a: (1) atividade vulcânica abaixo da geleira ou (2) barragem da drenagem da água de degelo (ice-dammed lakes). Atividade vulcânica abaixo de geleiras é comum na Islândia, um exemplo disto é Grimsvötn. A média do volume de descarga de Grímsvötn fica entre 3 e $3,5 \mathrm{~km}^{3}$. Em 1922 a descarga de um jökulhlaps atingiu aproximadamente $7,1 \mathrm{~km}^{3}$ de água com um máximo de descarga d'água de $570.000 \mathrm{~m}^{3} \mathrm{~s}^{-1}$. Isto é mais que o fluxo do rio Congo e quase um quarto do rio Amazonas (Bennet e Glasser, 1996).

Jökulhlaps causados por rompimento de barragem de gelo são mais comuns. Lagos formados por barragens de gelo ocorrem quando blocos de gelo impedem a passagem da água, relacionados normalmente a geleiras de vale. A liberação catastrófica da água represada pode estar associada a várias hipóteses: (1) alçamento da barragem de gelo causado pelo aumento do nivel de água do lago, que por conseguinte, aumenta a pressão hidrostática na base da barragem; (2) transbordamento, causado pelo rápido derretimento da barragem devido a fricção do fluxo de água; (3) destruição ou fissuramento da barragem de gelo por terremotos; e (4) ampliação de túneis préexistentes abaixo da barragem por aumento do fluxo de água e derretimento devido ao calor da fricção. 


\section{Reologia do Substrato}

Até o final da década de 70 , os modelos desenvolvidos para o fluxo glacial eram baseados em geleiras do tipo alpino, que se deslocavam sobre substratos rígidos. Da mesma forma, aceitava-se que os processos de erosão/deposição, resultantes do deslocamento das geleiras sobre embasamento rochoso, poderiam ser aplicados universalmente.

Com o avanço das pesquisas sobre a glaciação pleistocênica na Europa e América do Norte, aventou-se que espessas seqüências de sedimentos inconsolidados podiam ter servido de substrato para diversos avanços do gelo, durante a glaciação quaternária.

Bouton e Jones (1979) sugeriram, de forma pioneira, que a reologia dos sedimentos subglaciais deformáveis poderia constituir fator determinante do comportamento dinâmico das coberturas de gelo. Já em 1987. Alley et al, haviam apontado a possibilidade do fluxo de pelo menos uma das maiores correntes de gelo da Antártica (ice streams) poderia estar sendo controlado pela deformação de sedimentos subglaciais com alto conteúdo de água, o que foi posteriormente confirmado por Engelhardt et al. (1991), através de perfuração de poços até a base da geleira.

Inicialmente tentoumse caracterizar as condições necessárias para o início da deformação, através da Lei de Coulomb (Smalley e Unwin, 1968; Boulton, 1982).

$$
\varphi_{c}=P_{e} \tan \phi+C
$$

onde,

$\varphi=$ limite de elasticidade dos sedimentos sob ação da tensão de cisalhamento;

$\mathrm{Pe}=$ pressão efetiva, definida por $\mathrm{Pi}-\mathrm{Pw}$;

$\mathrm{Pi}=$ pressão normal exercida pelo gelo suprajacente;

$\mathrm{PW}=$ pressão hidrostática exercida pela água intersticial no sedimento;

$\phi=$ ângulo de friç̧ão interna;

$\mathrm{C}=$ coesão dos sedimentos

Entretanto, algumas dificuldades se interpõem à utilização deste modelo. A primeira diz respeito ao pressuposto que, em condições naturais, os sedimentos são substâncias perfeitamente plásticas, que não apresentam deformações até que seja 
alcançado o seu limite de elasticidade, exibindo uma razão de deformação infinitamente alta para aquele limite de elasticidade, desde que não haja incremento de tensão.

Outra dificuldade refere-se ao fato do modelo não incorporar nenhuma razão média, que deve ser levada em conta para o entendimento do comportamento isolado de duas substâncias de reologias diferentes: o gelo da geleira e o sedimento subjacente.

Boulton e Hindmarsh (1987), em experimentos de campo realizados no sudeste da Islândia, sob a geleira Breidamer-Kirjökull, uma grande geleira de escape da capa de gelo Vatnajökull, demonstraram que a razão de deformação dos sedimentos subglaciais depende de duas variáveis: o esforço cisalhante $(\varphi)$ e a pressão efetiva $(\mathrm{Pe})$.

Admitiu-se que o till se comporta como um fluido de Bingham, não exibindo deformação até que o limite de elasticidade de Coulomb seja alcançado (equação 1), e após o que apresenta um comportamento viscoso.

$$
\varepsilon=K \cdot P e^{-m}\left(\varphi-\varphi_{c}\right)^{n}
$$

onde,

$\varepsilon=$ taxa de estiramento

$\mathrm{K}, \mathrm{m}, \mathrm{n}=$ constantes

$\varphi_{c}=$ limite de elasticidade de Coulomb, vide equação (1)

A equação (2) é apropriada para um fluído de Bingham, em que não ocorre deformação até que seja alcançado o valor de Mohr-Coulomb do limite de elasticidade $\left(\varphi_{c}\right)$, sendo que, para valores elevados de esforço, o comportamento é viscoso não linear.

Todavia, Boulton e Hindmarsh op. cit., mostraram a ocorrência de deformação elástica-plástica significativa a niveis de esforços abaixo do limite de elasticidade $\left(\varphi_{c}\right)$, podendo, num longo periodo de tempo, produzir deformações importantes nos sedimentos.

Na equação (1), os valores de $K, \phi, C, n$ e $m$ são funções diretas da litologia e de seu estado de consolidação, tendo, portanto, grande influência na razão de deformação para um dado valor de esforço.

Outro parâmetro de grande importância na análise da deformação de sedimentos subglaciais é a pressão efetiva $(\mathrm{Pe})$, expressa pela relação $\mathrm{Pe}=\mathrm{Pi}-\mathrm{Pw}$, que reflete a interação entre a pressão do gelo suprajacente e a pressão d'água intersticial.

Esta interação pode controlar a pressão efetiva de tal forma que, em geral, sedimentos de granulometria fina e mais ricos em argila respondem, para um dado 
esforço, com taxas de deformação bem mais altas (Boulton, 1975, 1982 e 1986; Boulton e Jones, 1979). Esse processo ocorre por duas razões: a) a friç̧ão intergranular é reduzida e o conseqüente desenvolvimento progressivo de fabric no sedimento facilita o deslizamento interno interpartículas; b) sedimentos de granulometria fina possuem baixa permeabilidade e, conseqüentemente, para que a descarga de água através deles seja mantida é necessário que sejam mantidos altos gradientes piezométricos, os quais, por sua vez, produzem altas pressões intersticiais e baixas pressões efetivas. Sendo assim, a resposta ao esforço deformacional dependerá da eficiência da drenagem subglacial, que também influenciará a determinação das pressões efetivas.

Pode-se, portanto, imaginar um outro caso, oposto ao descrito acima, onde a geleira repousaria sobre um substrato constituído por sedimentos de granulometria grossa, permeáveis e não litificados. Neste caso, mesmo quando submetido a altas pressões efetivas, não ocorreriam deformações nos sedimentos, que se manteriam rígidos e passivos. O estabelecimento de uma drenagem eficiente (baixa pressão de água intersticial, $\mathrm{PW}$ ), sob condições de alta pressão efetiva $(\mathrm{Pe})$, ocasiona às condições reológicas básicas de substrato rigido, que promovem a deposição de tills de alojamento e/ou o desenvolvimento de superfícies polidas e estriadas.

Neste sentido, torna-se interessante comentar de que modo o regime térmico basal e sua variação afetam as condições deposicionais e erosivas subglaciais. Uma geleira cujo regime térmico basal seja frio, não irá propiciar condições favoráveis à deposição subglacial, pois, estará acoplada ao substrato. No caso de geleira de regime térmico quente, a presença de um filme d'água entre a geleira e o substrato, propicia condições para que haja deposição e/ou erosão subglacial, relação que irá depender do comportamento reológico do substrato e da eficiência de sua drenagem.

A aplicação dos conceitos acima no caso de depósitos glaciais pré-pleistocênicos depende, obviamente, da possibilidade de reconhecer feições diagnósticas das condições discutidas, sob a forma de depósitos e estruturas sedimentares.

Os pavimentos e superfícies estriadas produzidas por ação glacial sobre embasamento consolidado (Devoniano; Pré-Cambriano) ou intraformacionalmente, sobre sedimentos inconsolidados (Subgrupo Itararé) constituem as evidências mais importantes a serem estudadas. Outras estruturas, como as de deformação glacial (glaciotectônicas), afetando sedimentos inconsolidados do Subgrupo Itararé, também ocorrem na área estudada, confirmando que a reologia do substrato, juntamente com o regime térmico basal do lobo glacial Paraná influenciaram a gênese das formas de terreno aqui estudadas. 


\section{Erosão e deposição subglacial}

Segundo Bennett e Glasser (1996), erosão glacial é a remoção de fragmentos de rocha por uma geleira. Isto pode ocorrer através de 3 processos: abrasão glacial (g/acial abrasion); arrancamento glacial (glacial plucking); e pela ação da água de degelo. Abrasão glacial envolve o lixamento do assoalho glacial por detritos carregados na zona basal da geleira e é controlada, principalmente, pela pressão efetiva normal e a velocidade da geleira. Arrancamento glacial implica fraturamento do substrato e seu arrasto em baixo da geleira. Erosão por água de degelo, por sua vez, envolve a fragmentação e transporte do substrato através de abrasão fluvial, cavitação fluvial e solubilização química. A natureza da erosão glacial é dependente do regime termal da geleira, do suprimento de água de degelo na sua base e da taxa de deslizamento basal do gelo.

Boulton (1974) desenvolveu um modelo teórico para abrasão glacial, o qual assume que a pressão normal efetiva de uma geleira é função da pressão normal exercida pelo peso da capa de gelo e a pressão d'água presente na base da geleira, que age em oposição à pressão normal. Segundo esse modelo, a pressão normal efetiva controla a taxa de abrasão. Com o aumento da pressão normal efetiva, há o aumento da pressão normal sobre os clastos na base da geleira. Contundo, se a pressão normal efetiva aumenta, a fricção entre o clasto e o substrato também aumenta e por fim esta começará a retardar o movimento da partícula, ocasionando a diminuição da abrasão glacial. Consequentemente, se todas as outras variáveis permanecerem constantes (e.g., velocidade de deslizamento), a abrasão aumentará num primeiro instante em razão do acréscimo na pressão efetiva normal e diminuindo em seguida pela fricção entre os clastos e o substrato, o que leva à cessação do movimento das partículas e seu alojamento (tilito de alojamento, clastos embutidos etc.). (Fig. II-7.)

Contudo, o modelo acima pressupõe a pré-existência de uma saliência do embasamento, desse modo explicando satisfatoriamente a gênese de rochas moutonnées, whalebacks ( $=$ dorsos de baleia) e outros corpos alongados gerados em substrato duro. Inexiste na literatura de Geologia Glacial um modelo conceitual de erosão glacial aplicável ao caso de substratos glaciais essencialmente planos como é o caso do flanco sul do arco de Ponta Grossa.

Um modelo alternativo de abrasão glacial, proposto por Hallet (1979), baseia-se na premissa de que os clastos estão completamente envoltos por gelo e desse modo "flutuando" dentro dele. Isto ocorre porque o gelo deforma-se ao redor dos clastos por deslizamento, devido ao peso do gelo sobreposto, fazendo com que os clastos basais 
sejam efetivamente circundados por gelo todo tempo. Neste caso, a pressão de contato entre um clasto e o substrato é função da velocidade com que o gelo flui para baixo, forçando o clasto ao contato com o assoalho. Este modelo de abrasão independe das variações da pressão efetiva normal e está, principalmente, relacionado à taxa de derretimento basal e velocidade de fluxo glacial.

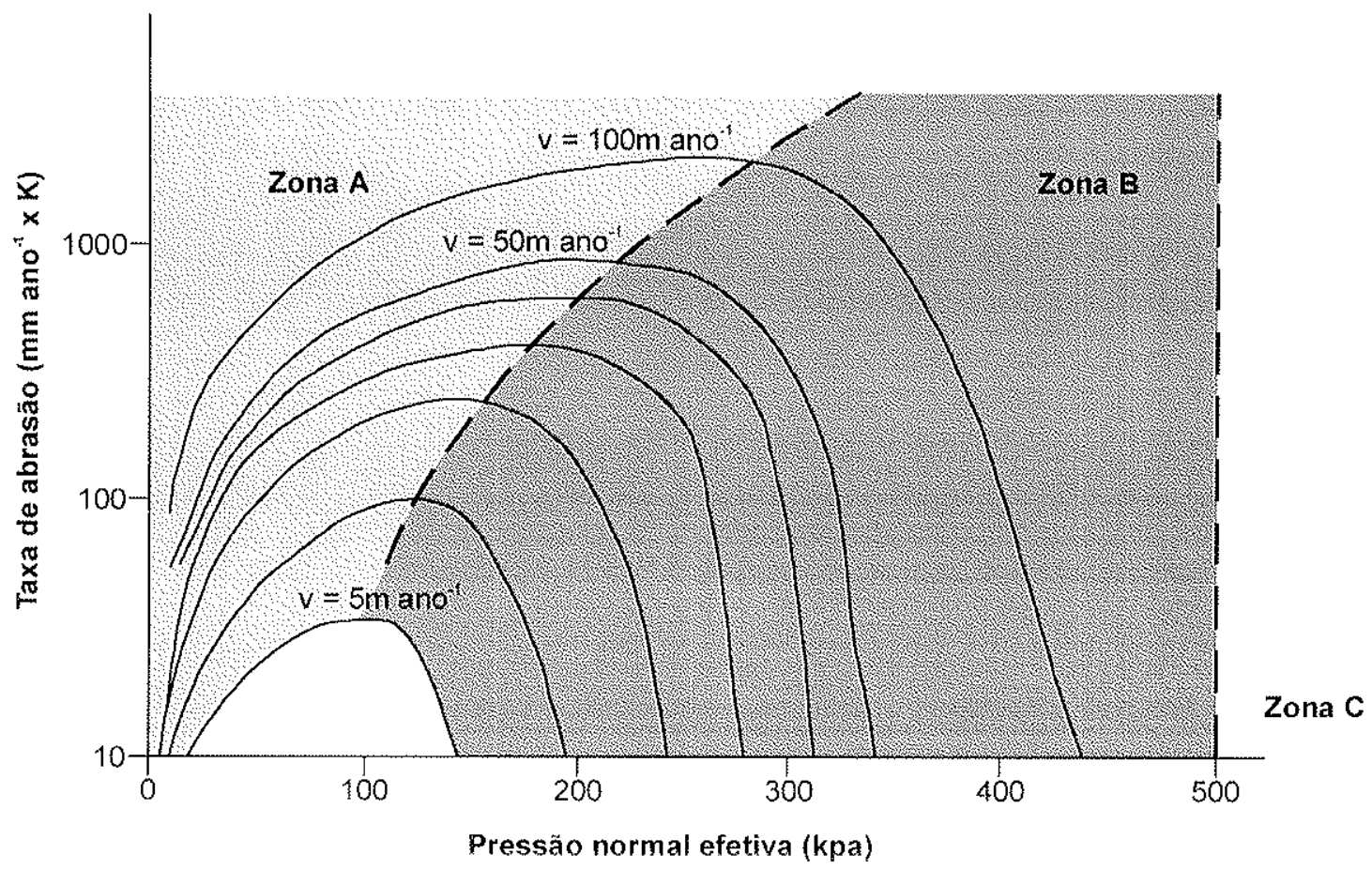

Figura 11-7: Representação gráfica do modelo de abrasão de Boulton. O gráfico mostra taxas de abrasão teóricas (ordenada) plotadas contra pressão normal efetiva (abscissa) para diferentes velocidades do gelo (v). Na zona $A$, as taxas de abrasão crescem com o aumento da pressão, enquanto na Zona $B$, as taxas de abrasão diminuem com o aumento da pressão. A Zona $C$, localizada à direita do maior valor de $x$, para qualquer velocidade, é uma zona de não-abrasão, onde o sedimento basal é depositado como till de alojamento. (Boulton, 1974).

Em resumo, portanto, o modelo de abrasão de Boulton envolve as seguintes premissas:

a) variação na espessura do gelo, que controla a abrasão e o alojamento, via pressão normal efetiva;

b) variação na pressão de água basal, que influencia na permeabilidade do substrato, controlando a abrasão glacial via, também, pressão normal efetiva;

c) velocidade de fluxo do gelo, que também influi na taxa de abrasão;

d) abrasão e alojamento formam parte de um continuum. 
As principais implicações do modelo de Hallet são as que seguem:

a) abrasão é alta onde o derretimento basal é grande;

b) abrasão é independente da pressão normal efetiva e, portanto, da pressão de água basal, embora a espessura da geleira ajude a controlar a taxa de derretimento basal; e

c) alojamento e abrasão são processos independentes.

Esses dois modelos contêm diferentes implicações que, à primeira vista, parecem conflitantes. Entretanto, apesar de cada modelo representar diferentes condições subglaciais, ambas são válidas. O modelo de Boulton e as implicações decorrentes deste, podem ser aplicadas a gelo basal particularmente "sujo" e rico em detritos e, portanto, comportando-se como uma espessa camada rígida. A natureza rígida desta camada impede a deformação do gelo ao redor de cada clasto. Em contraste, o modelo de Hallet pode ser mais apropriadamente utilizado em geleiras onde a camada de detritos basais seja fina e o gelo é, consequentemente, menos rígido. 


\section{III - FORMAS DE TERRENO GLACIAIS EROSIVAS E DEPOSICIONAIS}

Além de grande número de formas de terreno subglaciais erosivas identificadas na área de estudo, feições subglaciais deposicionais associadas foram também localizadas, embora em menor número.

Os trabalhos de campo revelaram também a ocorrência de prováveis formas de terreno deposicionais gláciommarginais, aparentemente com sua morfologia típica preservada, que foram pela primeira vez identificadas no registro geológico prépleistocênico. Embora o estudo do primeiro grupo de feições constitua o objeto principal da presente dissertação, as formas de terreno deposicionais sub e pró-glaciais foram também incluídas no estudo, não só pelo ineditismo de sua descoberta, como pela sua relevância na reconstituição das características do lobo glacial Paraná.

Para efeito sistemático, a discussão das formas de terreno erosivas e deposicionais neopaleozóicas seguirá as classificações de Summefield (1991, apud Bennett e Glasser, 1996) e Bennett e Glasser (1996), respectivamente (Tabela III-1).

Tabela III-1: Classificação das formas de terreno glaciais erosivas e deposicionais Summefield (1991, apud Bennett e Glasser, 1996) e Bennett e Glasser (1996). Somente alguns exemplos estão citados.

\section{A. FORMAS DE TERRENO EROSIVAS (NEGATIVAS)}

a. Microescala (tamanho $<1 \mathrm{~m}$ )

Estrias

Sulcos e cristas

b. Macroescala (tamanho $>1 \mathrm{~km}$ )

Paisagem de abrasão superficial

B. FORMAS DE TERRENO DEPOSICIONAIS

a. Subglaciais

Cristas de till (flutes)

b. Próglaciais ou glácio-marginais

Morainas de empurrão (push moraines)

No flanco sul do arco de Ponta Grossa, feições erosivas de microescala (estrias e sulcos) ocorrem em numerosos afloramentos de arenito da Formação Furnas, que constitui embasamento regional (Fuck \& Bigarella, 1967; Bigarella et al., 1967; RochaCampos, 1967), e intraformacionalmente sobre rochas sedimentares do próprio Subgrupo Itararé (arenitos e diamictitos; Canuto, 1985; Santos, 1987; Santos et al., 1996; Vesely e 
Assine, 1998, Rocha-Campos et al., 1999; no prelo; Trosdtorf Jr. et al., 2001). Em São Luís de Purunã elas estão associadas a feições deposicionais ou construcionais e por esta razão serão tratadas conjuntamente. No primeiro caso, os processos ocorrem sobre substrato duro (consolidado), enquanto que no segundo, sobre sedimentos não consolidados. Correspondem, pois, respectivamente, a pavimentos e superfícies estriadas. Embora as exposições rochosas possam variar em tamanho, de poucos $\mathrm{dm}^{2}$ a centenas de $\mathrm{m}^{2}$, a área total afetada pelos fenômenos erosivos compreende cerca de $1.500 \mathrm{~km}^{2}$, configurando uma forma de terreno erosiva de macroescala (paisagem de abrasão glacial).

As formas de terreno da área estudada serão discutidas com referência a algumas das principais exposições onde foram examinadas mais detalhadamente, a saber: a) erosivas (pavimento estriado de Witmarsum; superfícies estriadas de Palmeira e superfícies estriadas de São Luís de Purunã); e b) deposicionais (afloramentos junto ao rio Cancela).

\section{III.1 - Erosivas}

III.1.1 - Pavimento estriado de Witmarsum

Dezessete exposições de pavimentos formados sobre o arenito Furnas foram identificados na região (Bigarella et al., 1967; Fuck e Bigarella, 1967; Canuto, 1985). As exposições, no geral horizontais, localmente basculadas por falhamento, correspondem à superfície de discordância pré-Subgrupo Itararé. O afloramento mais conhecido na região ocorre em Witmarsum, junto às instalações da Cooperativa Agricola de Witmarsum (Bigarella et al., 1967; Fuck e Bigarella, 1967). Outra ocorrência excepcional foi localizada em afloramento da Fazenda Schroeder (Fig. 1-6). Em vários locais os pavimentos são recobertos por diamictito e arenito permo-carbonífero. A sua posição topográfica varia grandemente, envolvendo um desnivel total de cerca de $180 \mathrm{~m}$, provavelmente em razão do arqueamento tectônico imposto à região. A característica comum dos pavimentos é a presença de estrias e sulcos retilineos e paralelos. A orientação média das feições é de $\mathrm{N} 12 \mathrm{~W}$.

No famoso pavimento de Witmarsum, sulcos predominam sobre estrias, que ocorrem dentro daqueles e sobre as cristas intermediárias (Fig. III-1). Sulcos têm comprimento máximo visível de $10 \mathrm{~m}$, e largura e profundidade máximas de $40 \mathrm{~cm}$ e 10 $\mathrm{cm}$, respectivamente. Uma característica marcante do afloramento é a impregnação de limonita sobre o arenito. Esta cimentação secundária pode ter contribuído para a consolidação da rocha, favorecendo a preservação das feições. 
Dois corpos tabulares de diamictito subglacial superpostos (amarelo e vermelho), de alguns decímetros de espessura, recobrem o pavimento. Sobre o diamictito inferior foram notadas evidências pouco distintas da presença de sulcos, paralelos aos do pavimento.

Vale também ressaltar a inexistência de estruturas e/ou feições que indiquem o sentido de movimento do gelo. O fluxo glacial de sul para norte é inferido a partir de estruturas/feições presentes em outras localidades (e.g., superfície estriada de São Luís de Purunã) e dados de paleocorrentes do Subgrupo Itararé (Fuck e Bigarella, 1967).

\section{Origem e preservação}

A morfologia das microfeições, o modo de ocorrência e a associação direta com diamictito subglacial são inteiramente concordantes com a origem das microfeições por erosão subglacial do lobo Paraná, já aventada para o pavimento (Bigarella et al., 1967).

As dimensões dos sulcos sugerem abrasão sob condições de pressão efetiva relativamente alta, sob geleira de base quente (Bennett e Glasser, 1996). O paralelismo dos sulcos e estrias sobre o pavimento indica terem sido formados por um único evento erosivo. Sua cobertura por diamictito subglacial proporcionou proteção da superfície à erosão posterior. Neste caso, é provável que as estriações tenham a mesma idade que o diamictito imediatamente acima.

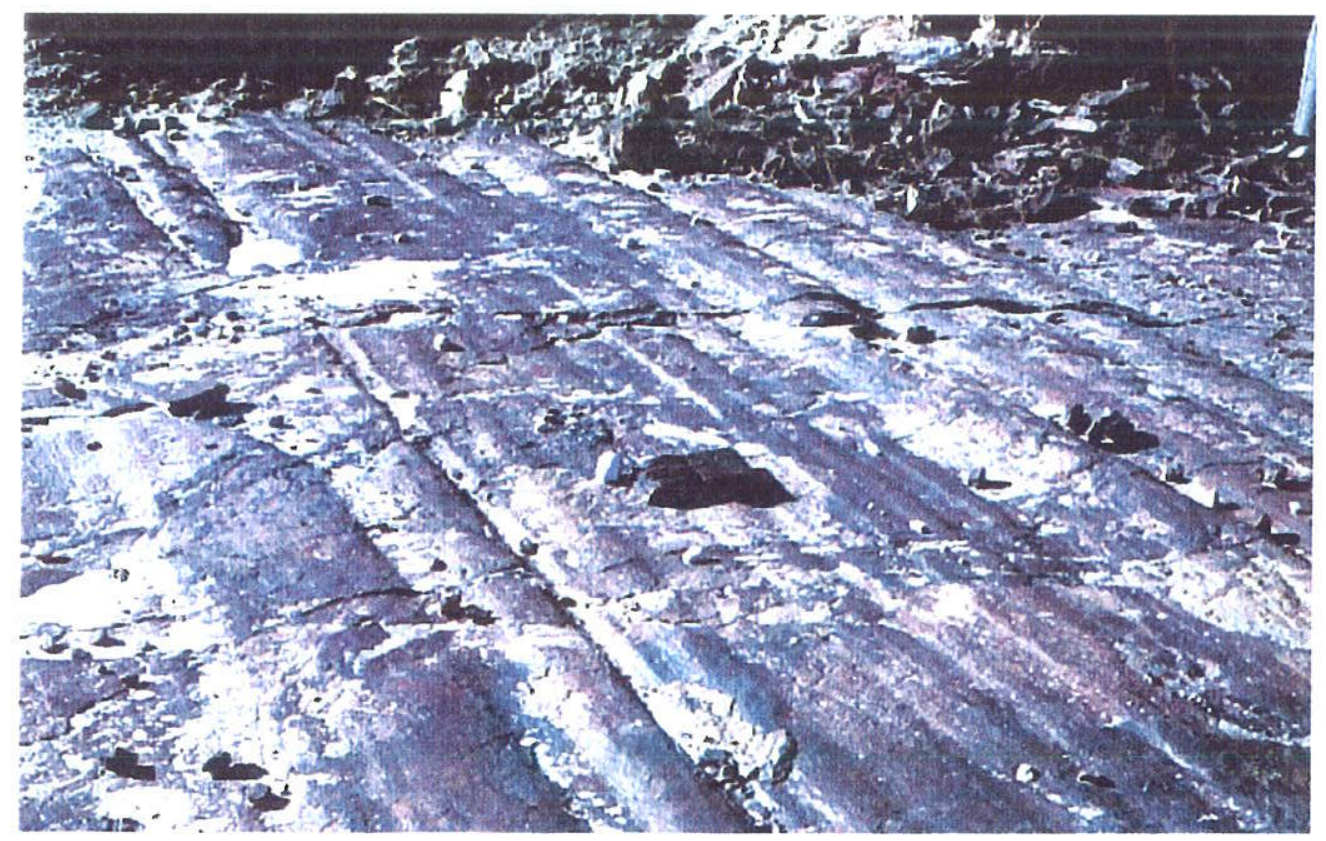

Figura III-1: Pavimento estriado de Witmarsum. Notar sulcos e estrias retilíneos e paralelos. Camada de diamictito subglacial recobre o pavimento ao fundo. 


\section{III.1.2 - Superfícies estriadas de Palmeira}

Afloramentos de micro-feições glaciais erosivas formadas sobre arenitos ou diamictitos do Subgrupo Itararé são também de ocorrência comum na região, com onze localidades conhecidas (Fuck e Bigarella, 1967; Bigarella et al., 1967; Canuto, 1985; Vesely e Assine, 1998; Rocha-Campos et al., 1999; 2000; no prelo; Trosdtorf Jr. et al., 2001). Do mesmo modo que no caso dos pavimentos estriados sobre o arenito Furnas, os afloramentos de superfícies estriadas são grandemente variáveis em área $\left(\mathrm{dm}^{2} \mathrm{a} \mathrm{m}^{2}\right)$, também no geral horizontais ou ligeiramente basculados, quando afetadas por falha, e de distribuição regional similar. Somente no afloramento de Witmarsum, os dois tipos de ocorrência de estriações glaciais foram encontrados estratigraficamente superpostos, no mesmo local. Estrias e sulcos sobre as superfícies são retilíneos e paralelos. Sua orientação média de $\mathrm{N} 25 \mathrm{E}$ difere significativamente, entretanto, da obtida para os pavimentos, $\mathrm{N} 12 \mathrm{~W}$.

A descoberta de afloramentos de superfícies estriadas múltiplas, intraformacionais, em arenito do Subgrupo Itararé (Canuto, 1985; Vesely e Assine, 1998; Rocha-Campos et al., 1999; 2000; no prelo; Trosdtorf Jr. et al., 2001) suscitou enorme interesse e controvérsia quanto à sua origem, modo de preservação e implicações glaciológicas. Além do exemplo de Palmeira, outro afloramento foi localizado durante a presente pesquisa na região de Witmarsum (Fig. IV-10). Formado sobre arenito médio a grosso, marinho, é caracterizado por estrias e sulcos paralelos e retilíneos, sendo que os sulcos maiores atingem até $50 \mathrm{~cm}$ de largura. O exemplo mais notável de superfície erodida sobre diamictito ocorre em São Luis de Purunã (Vesely e Assine, 1998). Tendo em vista as suas peculiaridades, as superfícies de Palmeira e Purunã merecem discussão mais pormenorizada.

As superficies de Palmeira ocorrem em vários niveis estratigráficos dentro de pacote de cerca de $3,5 \mathrm{~m}$ de arenito com intercalações de siltito argiloso da parte inferior do Subgrupo Itararé, aflorante em cortes dos dois lados da rodovia BR-277, $\mathrm{km} \mathrm{157.} \mathrm{A}$ Figura III-2 exibe esquema ilustrativo da sucessão estratigráfica neopaleozóica da área. O contato do Subgrupo Itararé com arenito da Formação Furnas, embora não aflorante, deve situar-se a poucos metros abaixo do nível da rodovia.

Vale notar que o afloramento foi mapeado como pertencente à Formação Furnas por Fuck et al. (1965; Folha Quero-Quero, 1:50.000). Caracteristicas sedimentológicas e orientação de paleocorrentes permitem, entretanto, separar as duas unidades, o que é confirmado pela ocorrência das estriações glaciais. 
seleção ao longo do afloramento. Estruturas sedimentares primárias presentes incluem estratificação cruzada acanalada e tabular de médio a pequeno porte, às vezes contorcidas por fluidificação e associados à estruturas de escape de água. Marcas onduladas assimétricas são visíveis na parte média e superior do corte, onde estratificação plano-paralela e cruzadas de baixo ângulo tornam-se mais freqüentes e elas ocorrem lado a lado com estriações em uma das superfícies (Figs. III-7 e 8).
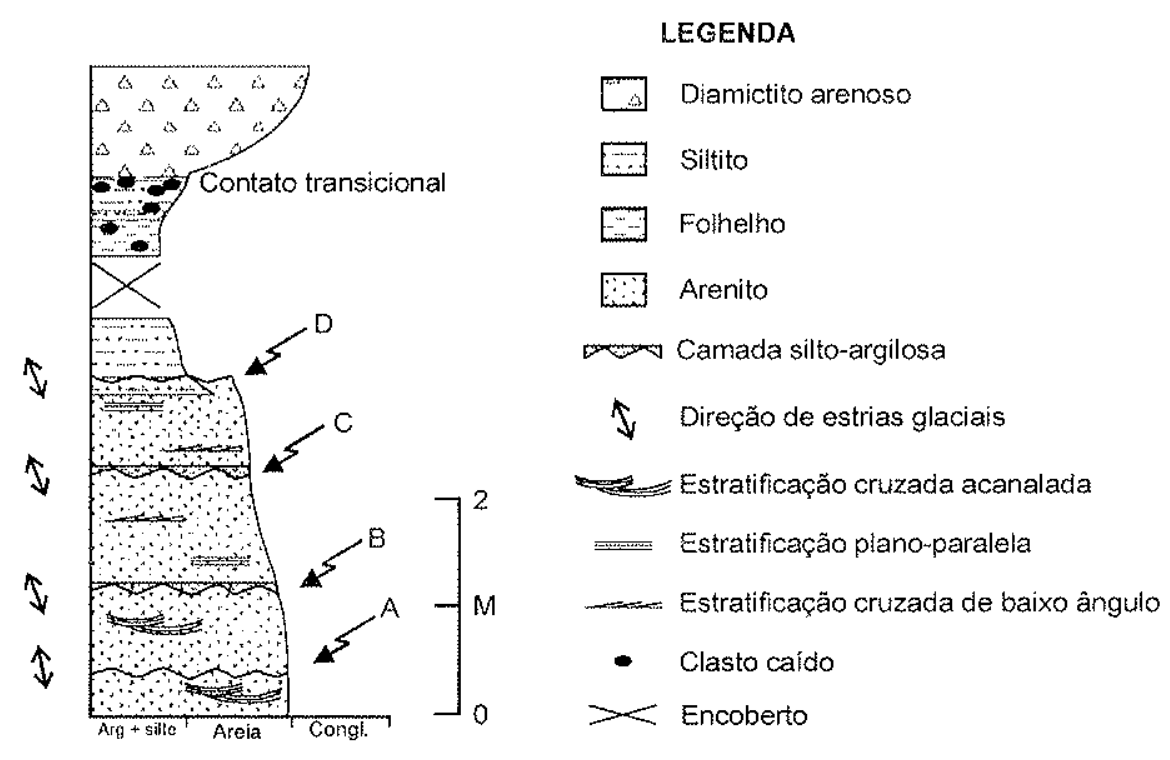

Figura III-2: Seção colunar do Subgrupo Itararé em Palmeira, PR. As letras A a D indicam superficies estriadas.

Exposições de pelo menos quatro superfícies estriadas foram distinguidas na seção de Palmeira, denominadas, de baixo para cima $A-D$, a primeîra no chão, do lado direito da rodovia (em direção à Palmeira) e três outras no corte do lado esquerdo (Fig. III-2).

A superfície A, mais bem exposta, com cerca de $2,5 \mathrm{~m}^{2}$, mostra-se horizontal e no geral plana. Está densamente coberta por estrias e sulcos retilíneos e paralelos de até 4 $\mathrm{cm}$ de largura e profundidade de até $1 \mathrm{~cm}$. Depressões arredondadas, rasas, de cerca de $10 \mathrm{~cm}$ de diâmetro, contornadas pelas estrias, podem representar moldes de objetos, temporariamente fixados sobre a superfície (Figs. III-3 e III-4).

As superfícies B-D situam-se no lado esquerdo da rodovia, ao longo de extenso corte com cerca de $70 \mathrm{~m}$ de comprimento. As exposições são menores em área, ocorrendo sob a forma de patamares de largura variável de até $80 \mathrm{~cm}$. Em corte, os traços das superfícies, grosso modo, subhorizontais, são ondulados podendo às vezes juntar-se, ou ser menos visiveis, o que torna difícil sua distinção. 


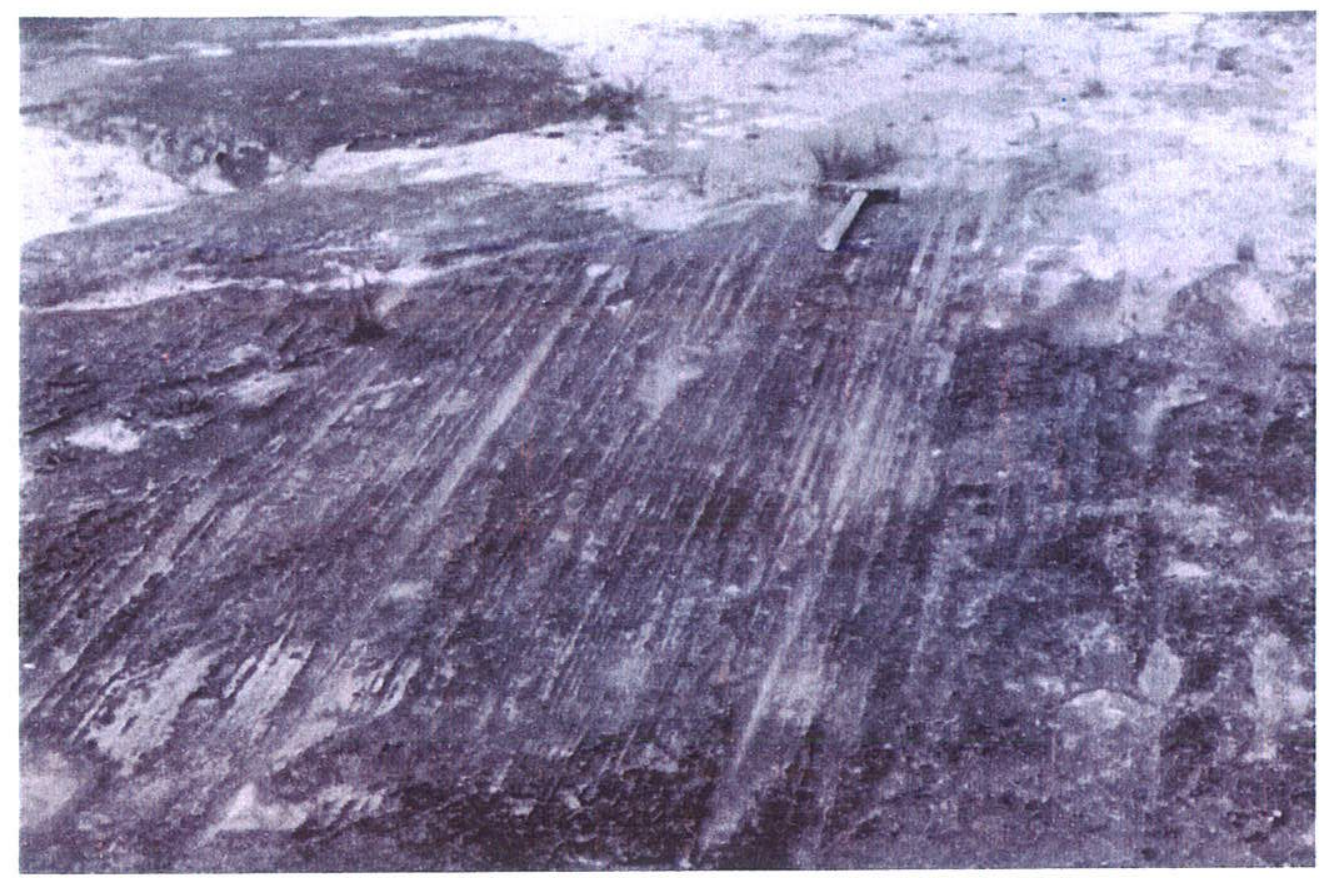

Figura III-3: Superfície estriada inferior (A), lado direito da rodovia BR-277, km 157, em direção a Palmeira. Notar sulcos e estrias retilíneos e paralelos.

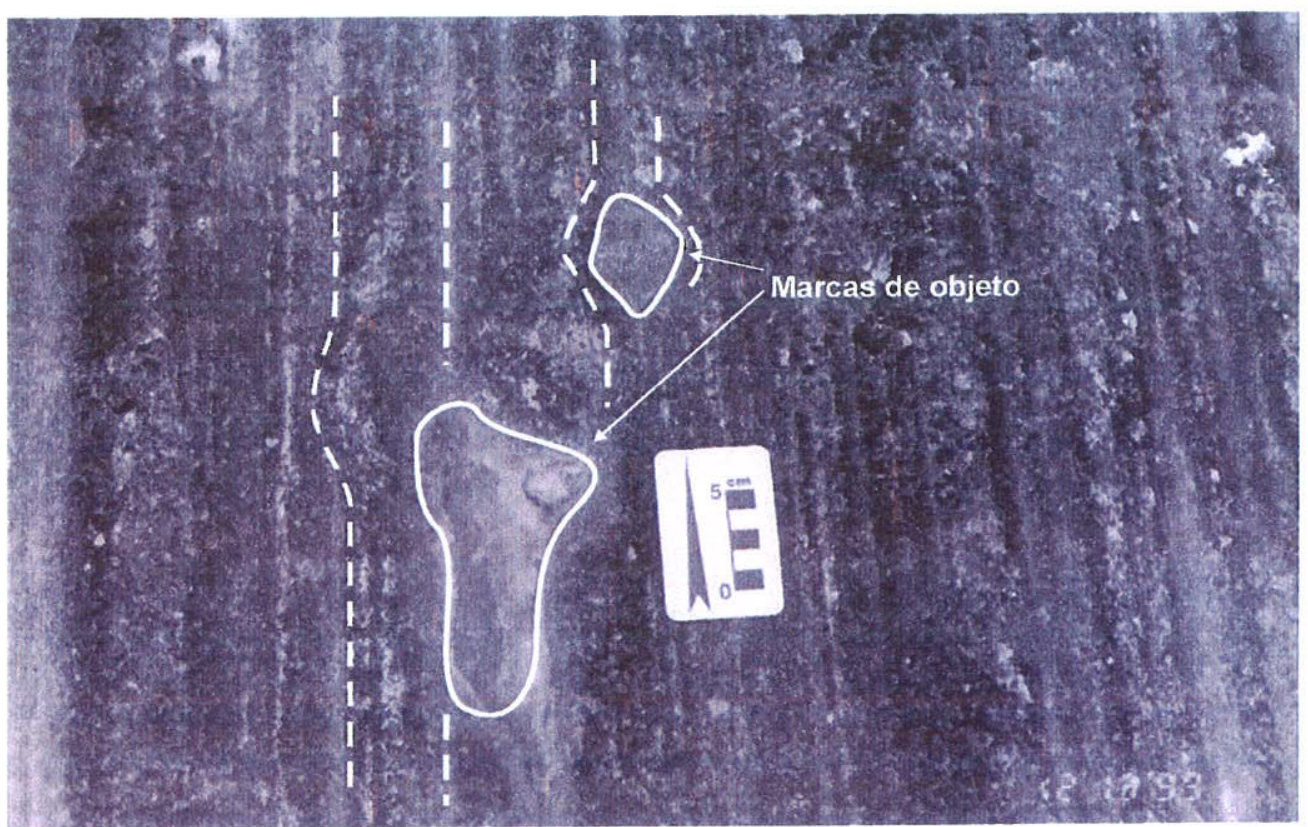

Figura III-4: Marcas de assentamento de objeto sobre a superfície estriada A. Notar alteração no curso das estrias ao redor das marcas.

Em vários locais, as superfícies estriadas B e C estão separadas do pacote de arenito que recobre cada uma delas por camada fina (centimétrica) de siltito argiloso, lateralmente descontínuas (Fig. III-5). Essa relação sugere que as superfícies estriadas 
correspondam a planos de estratificação irregulares do arenito. As microfeições glaciais erosivas parecem menos preservadas nos locais em que o siltito argiloso não está presente. A superfície estriada $D$, por sua vez, está recoberta por camada lenticular de siltito-arenoso de $40-1 \mathrm{~m}$ de espessura.

Sulcos e estrias retilíneos e paralelos ocorrem nas três superfícies. Os primeiros variam no geral de $2-3 \mathrm{~cm}$ até $7-10 \mathrm{~cm}$ de largura e $1-2 \mathrm{~cm}$ de profundidade. Estrias cobrem as cristas entre os sulcos e no seu interior. A orientação das feições varia de N10 - 24W (Fig. III-6). As dimensões dos sulcos parece aumentar entre as superfícies B-D, onde chegam a formar calhas de até $12 \mathrm{~cm}$ de largura (Fig. III-7).

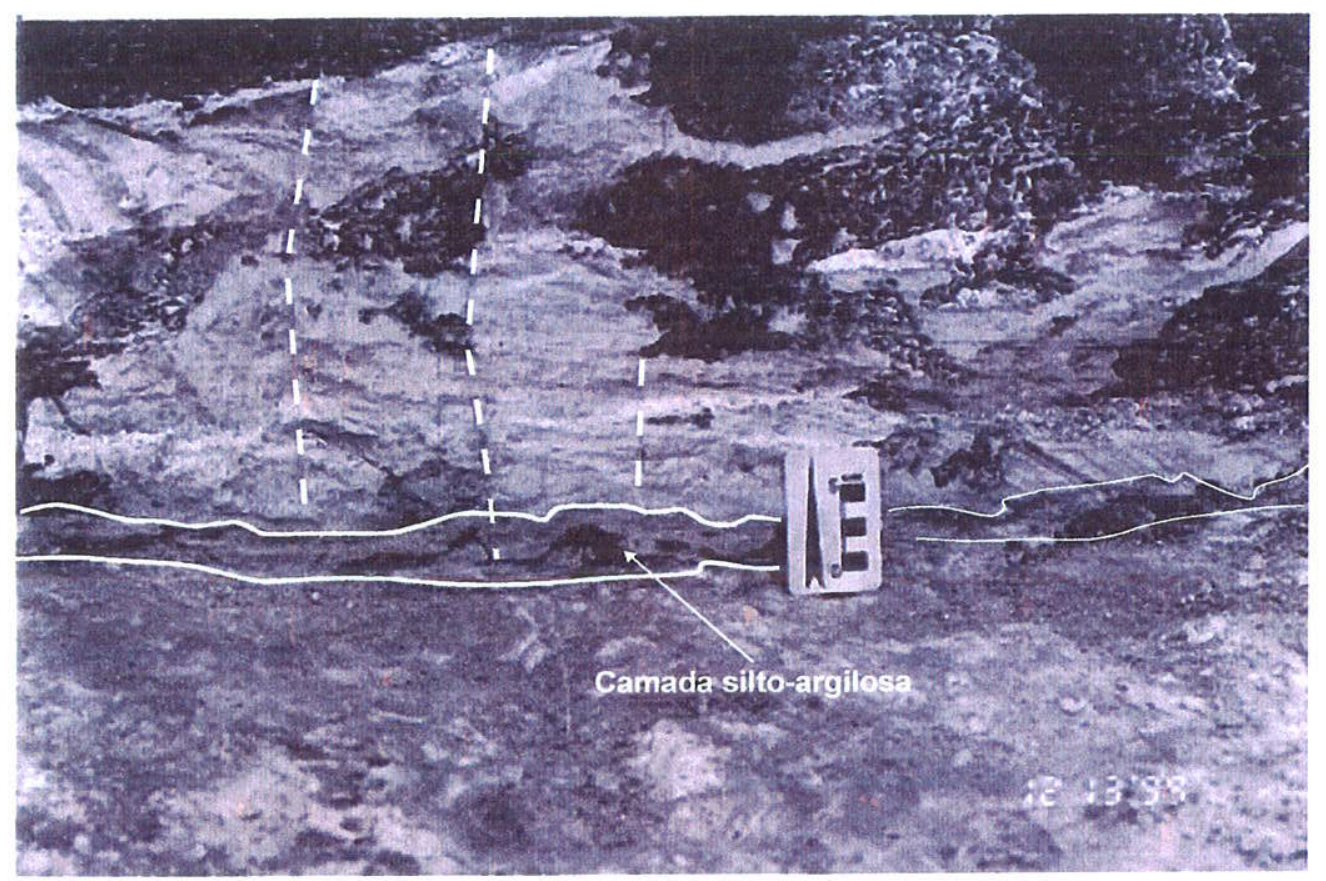

Figura III-5: Camada silto-argilosa intercalada entre duas camadas de arenito, recobrindo parcialmente a superfície C. Linhas interrompidas: fraturas

A despeito das evidências de intensa erosão glacial do arenito, não se nota no afloramento evidências de deformação interna intensa, no interior das camadas estriadas, por exemplo, através de cisalhamento. Estruturas sedimentares, por exemplo, parecem estar relativamente intactas, como no caso da superfície estriada D, que alterna lateralmente com áreas cobertas por marcas onduladas assimétricas, as quais indicam direção de transporte para NNW (Fig. III-8). Em alguns locais, entretanto, as camadas de arenito abaixo das estriações estão cortadas por fraturas internas, verticais a subverticais, que terminam ao nível das estriações, sem afetá-las (Fig. III-9). 


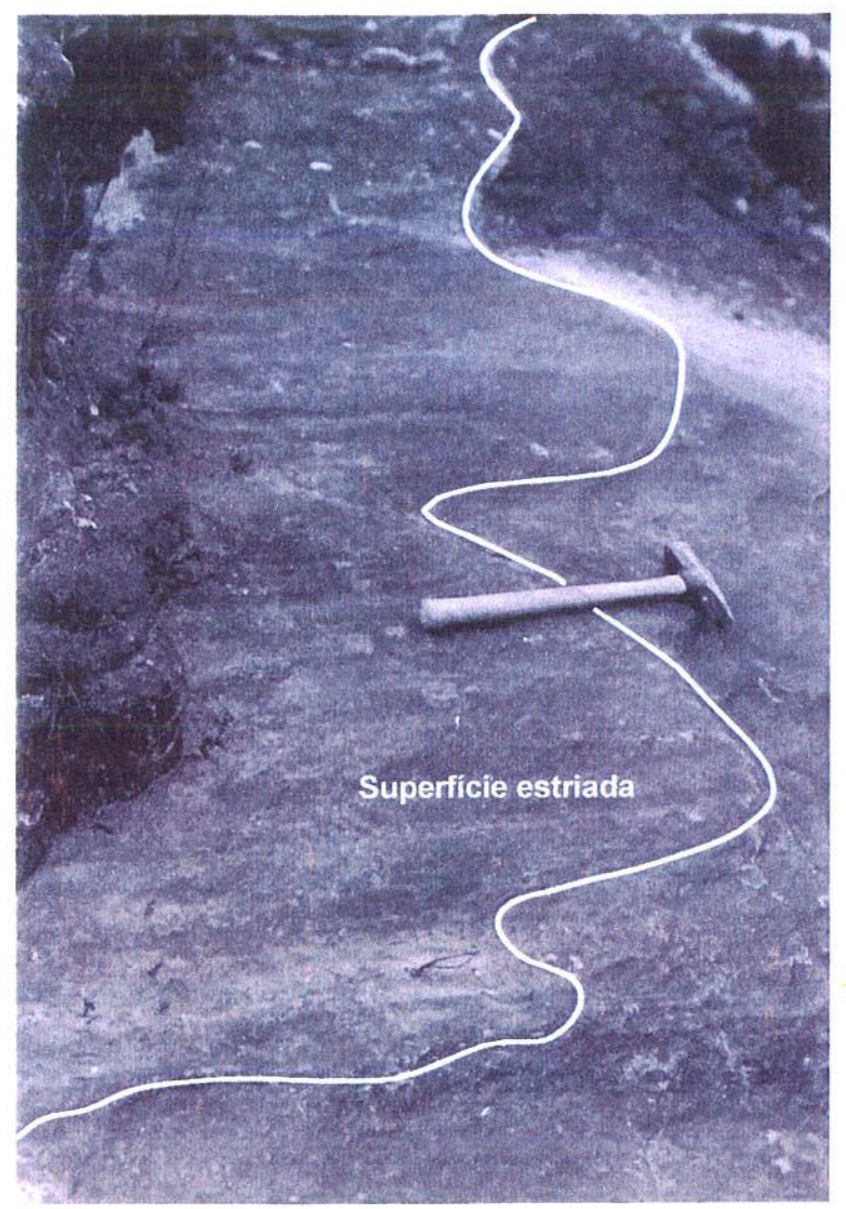

Figura III-6: Estrias e sulcos sobre a superfície estriada B. Área à direita da linha branca está erodida.

Reconhecimento realizado nos arredores do afloramento revelou que o arenito estriado é sucedido por camada de folhelho siltico contendo clastos caídos, que passam transicionalmente para diamictito silto-argiloso. O tipo de contato entre estas litologias e o arenito inferior não está, entretanto, visível.

\section{Origem e preservação}

A origem glacial das microfeições erosivas, formadas sobre rochas sedimentares do Subgrupo Itararé, pode ser estabelecida com base no contexto geológico geral das ocorrências e suas características morfológicas (Bigarella et al., 1967; Rocha-Campos et al., 2000; no prelo; Trosdtorf Jr. et al., 2001). 


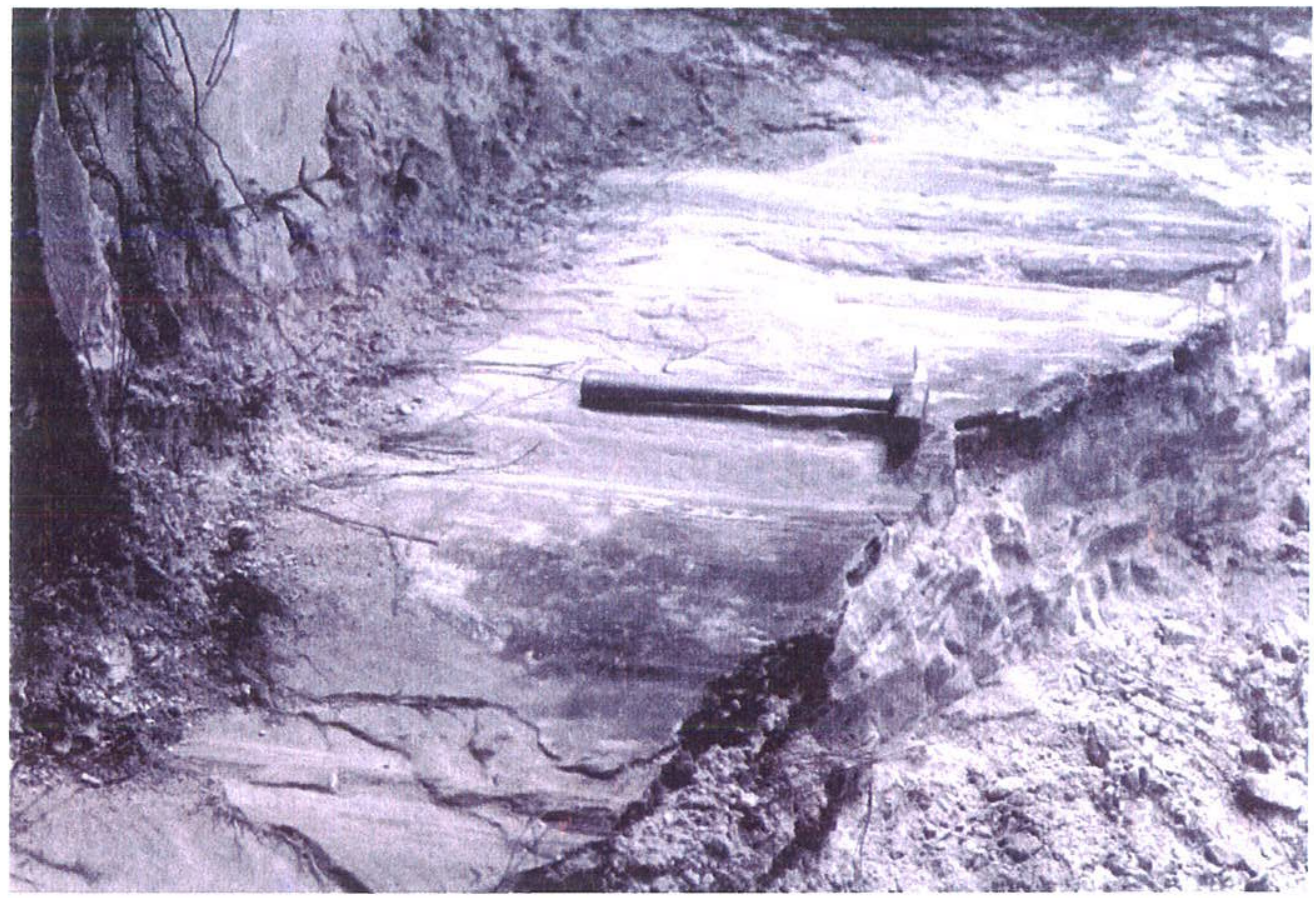

Figura III-7: Superfície estriada D, mostrando estrias e sulcos paralelos, sob camada de siltito. Notar sulcos mais largos e profundos que das superfícies inferiores e a persistência as estruturas em lâminas inferiores do arenito.

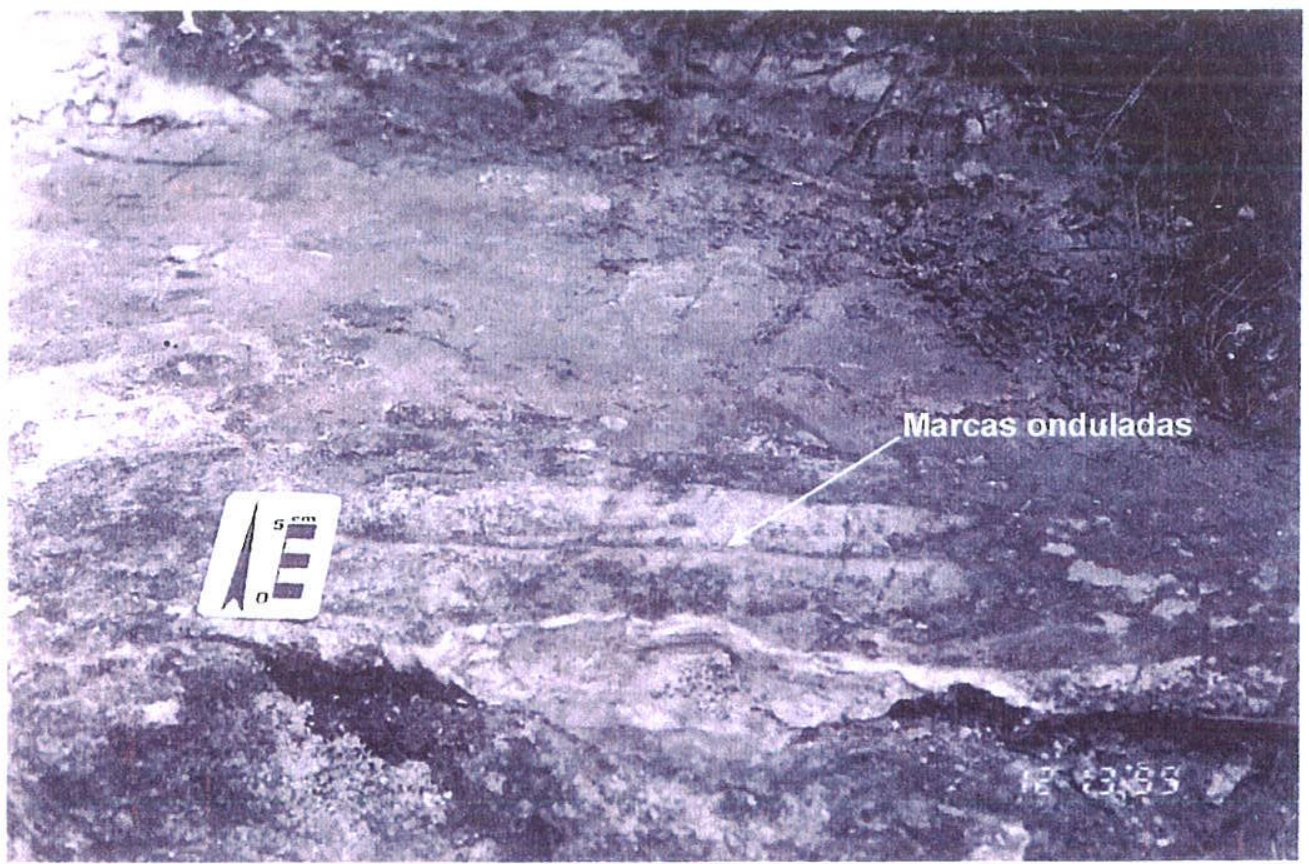

Figura III-8: Marcas onduladas assimétricas de direção de transporte para NNW, sobre a superfície estriada D. 


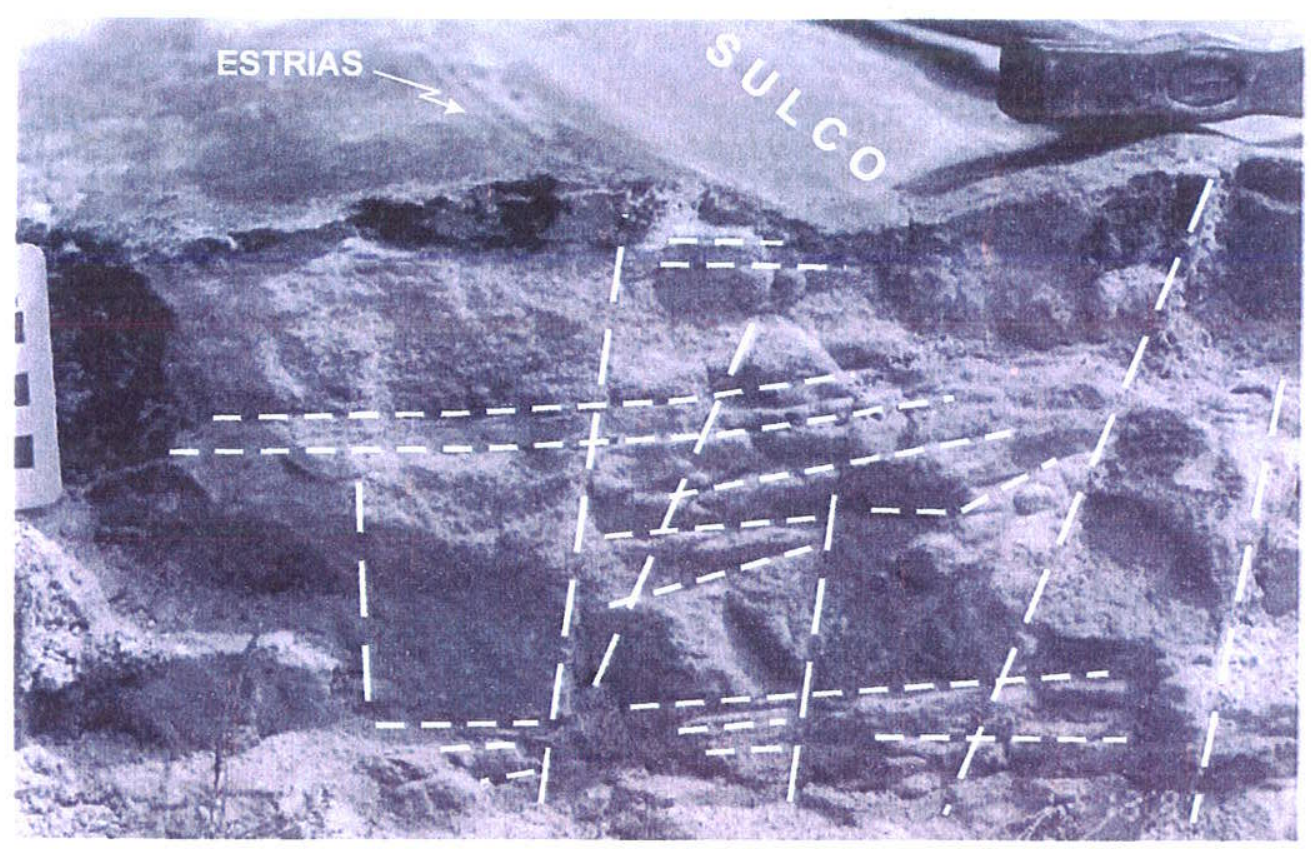

Figura III-9: Fraturas subverticais em arenito abaixo da superfície estriada D. Notar que fraturas não deslocam superfície estriada $\mathrm{D}$.

O mesmo raciocínio aplica-se ao caso das superfícies múltiplas. A repetição estratigráfica de superfícies estriadas glaciais intraformacionais constitui, entretanto, um aspecto geológico peculiar, com importantes implicações na reconstituição da dinâmica do lobo glacial Paraná, conforme aqui discutido.

Em ambos os casos acima, várias evidências indicam que a abrasão glacial ocorreu durante a movimentação de geleira sobre substrato sedimentar, ainda inconsolidado. Rocha-Campos et al. (2000; no prelo) listam as seguintes evidências observadas em superfícies estudadas no neopaleozóico e pré-cambriano do Brasil.

- A própria ocorrência repetida das superfícies estriadas, paralelas entre si e separadas por espessuras pequenas do mesmo sedimento, face as condições envolvidas no processo de litificação ou diagênese;

- a presença de abas de sedimento escorregado a partir de cristas adjacentes, para dentro de sulcos, recobrindo estrias;

- grande sinuosidade de sulcos e estrias. 
Descrições de superfícies estriadas, de qualquer idade, similares às aqui discutidas são, excepcionalmente raras na literatura. O único exemplo de que temos notícia é a de O'Brien e Christie-Blick (1992), no neopaleozóico da Austrália. Os autores descrevem uma série de seis superfícies estratigraficamente repetidas, formadas em arenito glácio-marinho, geradas por erosão recorrente de geleira aterrada sobre depósitos de lavagem glacial, marinhos rasos.

Nos depósitos glaciais pleistocênicos e recentes, formas de terreno subglaciais deposicionais (flutes, drumlins etc.) têm sido observadas em áreas deglaciadas, bem como sob a forma de marcas de sola, na base de camadas de till (Sharp, 1982; Boulton, 1987; Boyce e Eyles, 1991). Nossa pesquisa revelou ainda a quase ausência de relatos sobre a ocorrência de superfícies estriadas extensas formadas em substrato "mole". Um único caso é descrito por Clark e Hansel (1989), no Pleistoceno de Illinois. Os autores atribuem a preservação da estrutura à cimentação carbonática do substrato arenoso por cimentação subglacial sinssedimentar.

Obviamente, essas superfícies podem ter-se formado e ocorrer, internamente, em sucessões glaciogênicas pleistocênicas e recentes. Como regra geral, contudo, provavelmente não se tornam facilmente expostas, em razão da erosão rápida dos depósitos. A possibilidade de preservação através de cimentação subglacial por carbonato, proposto por Clark e Hansel (1989), para superfície estriada do Pleistoceno de Illinois, não parece aplicar-se ao caso de Palmeira. Uma possibilidade que pode ser aventada é que as superficies tenham sido protegidas de destruição pela sua cobertura por depósitos silto-argilosos, formados em corpos de água instalados sobre a superfície arenosa.

O caráter intra-bacia sedimentar dos depósitos pré-pleistocênicos, de outro lado, implica continua subsidência e acumulação de sedimentos mais jovens, que podem incluir camadas marinhas transgressivas pós-glaciais, seguida de diagênese (Eyles, 1993). Superfícies estriadas, compactadas subglacialmente, são ainda frequentemente sujeitas à cimentação superficial adicional e endurecimento durante o intemperismo.

As superfícies estriadas de Palmeira indicam fluxo ou deslizamento de geleira de regime térmico basal quente sobre substrato arenoso, inconsolidado. A ausência de clastos alojados no arenito, em associação com estrias e/ou sulcos, mostram que a erosão da areia foi feita por protuberâncias do gelo na base da geleira, de base plana. $A$ marca de objeto, acima mencionada, poderia pois, estar associada ao desprendimento de fragmento de gelo. O processo de erosão subglacial parece, pois, ter sido por aração (plowing) do substrato. Clark e Hansel (1989) descrevem processo similar para a formação da superfície estriada de Illinois. 
A despeito da natureza inconsolidada do substrato, não encontramos alças de sedimentos acumulados pela ação da aração (sediment prows) descritos pelos autores acima, a não ser em torno da marca de objeto. As únicas evidências claras de deformação do arenito são as fraturas que cortam as camadas de arenito estriado. A pressão efetiva do gelo sobre o arenito, teria gerado distensão horizontal e a formação de fraturas de tensão. O arenito ter-semia, pois, comportado como um substrato rígido, relativamente incompetente, possivelmente em razão de baixa pressão de água intersticial e boa drenagem da água de degelo subglacial. A geleira possivelmente tocava levemente o substrato de maneira descontínua, em parte flutuando sobre camada de água subglacial.

O ambiente glacial apontado pelas características sedimentológicas do arenito é de planície de lavagem glacial arenosa, proglacial, na porção basal do afloramento. Estruturas sedimentares na parte superior do pacote sugerem passagem para condições marinhas rasas. Neste caso, pode-se pensar em ambiente de planície proglacial costeira. Condições marinhas mais francas estariam documentadas pelo folhelho com clastos caídos na parte superior da seção, provavelmente refletindo uma transgressão posterior ao recuo final do gelo. Vale também ressaltar, que o ambiente marinho raso propicia maior proteção a superfície estriada, sendo por isso que as mesmas se apresentam mais extensas (aproximadamente $60 \mathrm{~m}$ ) e melhor preservadas que as superfícies inferiores.

A repetição do processo abrasivo glacial, documentado pelas superfícies múltiplas, separadas por pequenas espessuras de sedimentos e o paralelismo das estrias e sulcos, coaduna-se mais com uma oscilação de margem de geleira relativamente rápida e não múltiplos avanços glaciais. Deve-se lembrar, contudo, que parte da areia depositada sobre uma superfície deve ter sido erodida durante avanço posterior.

A inexistência de depósitos de diamictito (=till subglacial) na seção, é também um tópico controvertido. O deslocamento da geleira sobre substrato formado pelo arenito da Formação Furnas poderia levar a incorporação de grande quantidade de areia na camada basal de detritos do gelo, posteriormente depositada e retrabalhada pela água de degelo.

Assim como o pavimento de Witmarsum, não há evidências do sentido de fluxo do gelo nas superfícies estriadas de Palmeira. Contudo, forma de relevo positiva, formado sobre arenito, com estrias em seu lado sul, semelhante a uma rocha moutonneé, indica fluxo de sul para o norte. 


\section{III.1.3 - Superfícies estriadas de São Luís de Purunã}

Outro afloramento de excepcional importância para os objetivos da presente dissertação situa-se junto ao $\mathrm{km} \mathrm{136,} \mathrm{no} \mathrm{lado} \mathrm{direito} \mathrm{da} \mathrm{rodovia} \mathrm{BR-376,} \mathrm{no} \mathrm{sentido} \mathrm{de}$ Curitiba, nas proximidades de São Luís de Purunã, PR. Vesely e Assine (1998) descreveram inicialmente as formas de terreno glaciais erosivas presentes e discutiram sua origem (Fig. III-10). Observações feitas durante a presente pesquisa complementam a descrição apresentada e adicionam novos elementos para a interpretação do modo de formação das feições. A localização do afloramento no quadro da estratigrafia local do Subgrupo ltararé e seu significado em termos de Geologia Glacial é mostrada na Figura III-11.

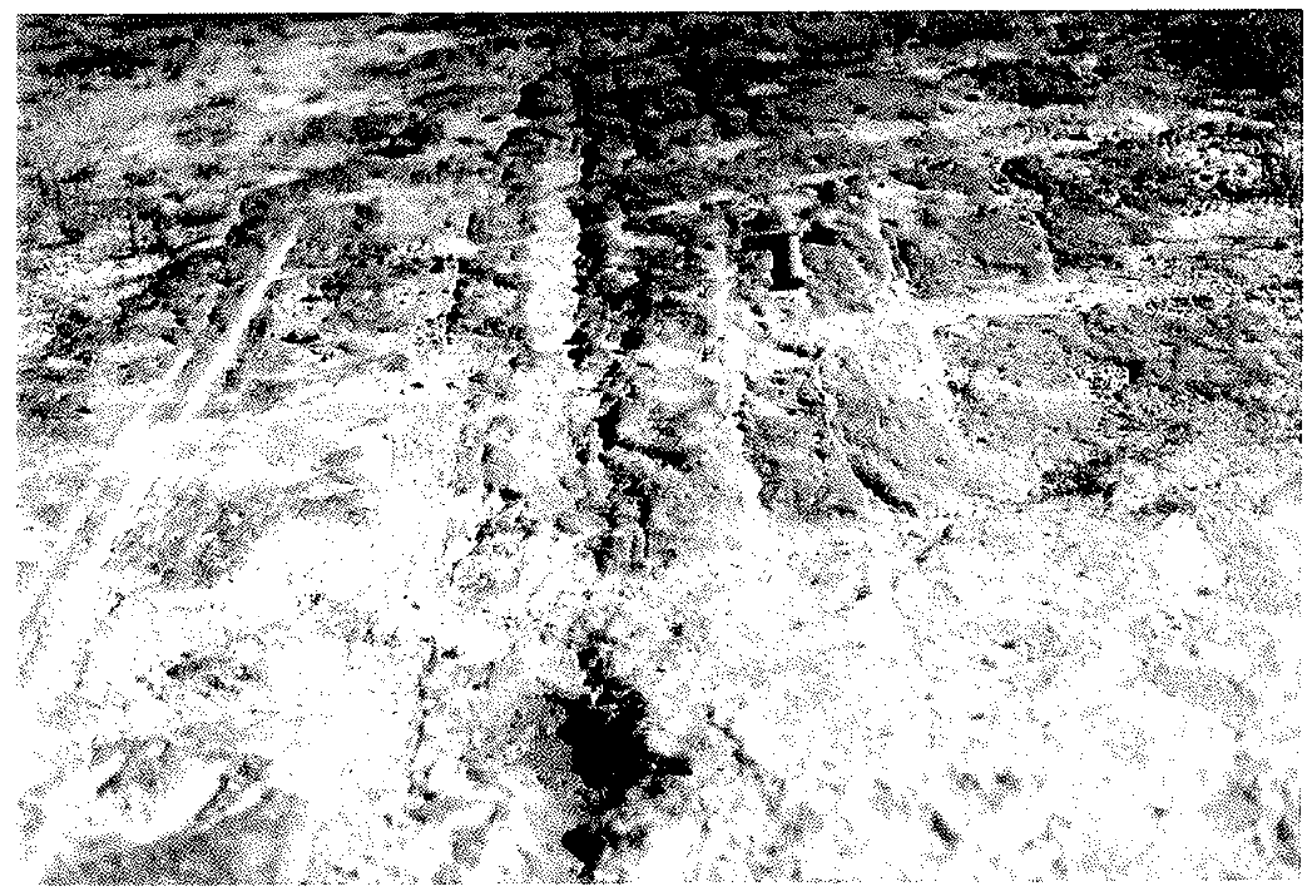

Figura 111-40: Vista geral da superfície. Sulcos/estrias glaciais e artificiais sobre superfície estriada superior em São Luís de Purunã. Os últimos foram produzidos durante a construção da rodovia. Martelo indica a direção das estrias glaciais. Notar que os sulcos artificiais cortam os glaciais.

Características do diamictito e outras rochas locais mostradas na Figura III-11, foram observadas em ravina que desce paralelamente à rodovia, na extremidade oeste do afloramento. Vê-se aí que o diamictito, no geral maciço, em bancos decimétricos a de até 4-5 $\mathrm{m}$ intercala-se com camadas de arenito, também decimétricos e métricos, compondo pacote de cerca de $10 \mathrm{~m}$ de espessura, assentado sobre arenito da Formação Furnas. 


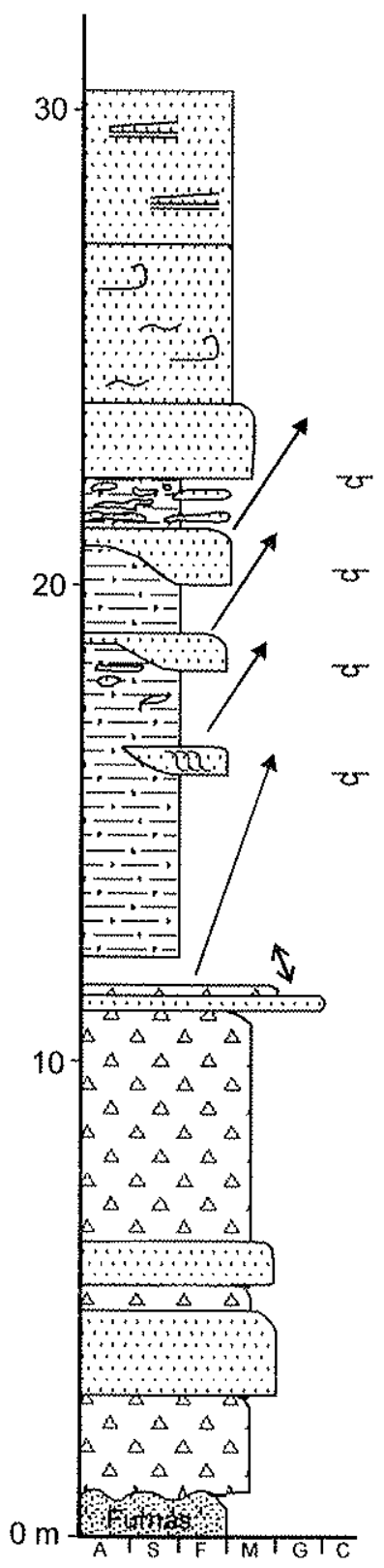

\section{LEGENDA E SÍMBOLOS}

4. Diamictito maciço, ocre a avermelhado, com clastos $\mathrm{cm}$-dm e lentes de arenito intercaladas Siltito com clastos caídos

Arenito

Arenito Furnas

Estratificação cruzada de baixo ângulo

v Estruturas de sobrecarga

7 Deformações (fraturado e cisalhado)

$\$$ Superficie estriada

ra. Estratificação cruzada sigmoidal

Figura IIl-11: Seção geológica de São Luís de Purunã, Notar estruturas de sobrecarga e lobos arenosos que ficam mais freqüentes no topo da seção.

\section{Formas erosivas}

As feições mais notáveis do afloramento são sulcos e estrias, no geral, retilíneos e paralelos, irregularmente distribuídos por toda a superficie plana do terreno, com cerca de $1500 \mathrm{~m}^{2}$. A rocha local é um diamictito de matriz silto-argilosa, no geral maciço, de textura heterogênea. Clastos centimétricos a matacões de mais de $1 \mathrm{~m}$ de diâmetro, muitos facetados e estriados, estão caoticamente dispersos no diamictito. Sulcos atingem pelo menos 11 metros de comprimento e têm largura e profundidade variável, de até 40 
$\mathrm{cm}$ e $5 \mathrm{~cm}$, respectivamente. Sua orientação varia entre N5E e N2W. Estrias distribuemse sobre as cristas entre os sulcos e dentro destes, em ambos os casos paralelamente. Dimensões de sulcos e estrias variam também longitudinalmente, não só refletindo ação erosiva irregular, em parte controlada pela natureza textural heterogênea do diamictito original, como também pela alteração intempérica posterior.

O afloramento foi artificialmente exposto por escavação, durante construção da rodovia. Desse modo, sulcos paralelos similares aos glaciais cruzam o terreno, porém de orientação variada, interceptam as feições glaciais (Fig. Ill-10). Estrias internas, paralelas no sulcos glaciais e sobre cristas, e outras feições erosivas e deposicionais associadas, permitem, entretanto, diferenciar as feições glaciais das artificiais.

Outras formas de terreno de micro - escala associada às estrias e sulcos, relevantes para o entendimento da origem das feições incluem:

- abas de diamictito cobrindo lateralmente estrias internas a sulcos. Representam, provavelmente, massas de sedimento removidos dos sulcos durante a erosão glacial e acumulados nas cristas laterais e, posteriormente, escorregadas para dentro das depressões (Fig. III-12). As abas podem exibir estriamento denotando continuidade do processo erosivo;

- inflexões de sulcos, indicando comportamento "plástico" da matriz, formando, às vezes, conjuntos arqueados;

- clastos alojados no diamictito, de topo truncado e estriado paralelamente às outras feições lineares (Fig. III-13); e

- cristas de diamictito a jusante de clastos embutidos no diamictito. A dimensão das cristas variam de $10 \mathrm{~cm}$ a cerca de $10 \mathrm{~m}$ de comprimento, $80 \mathrm{~cm}$ de largura e $15 \mathrm{~cm}$ de altura. Embora, provavelmente, também geradas subglacialmente, estas formas de terreno são tecnicamente consideradas deposicionais e serão, portanto, tratadas a parte.

Além da acima descrita, a erosão atual expõe uma pequena porção de superfície estriada, cerca de $20 \mathrm{~cm}$ abaixo da principal. Apesar do mau estado de preservação, é possivel observar estrias e sulcos retilíneos, paralelos e similares às superiores. A erosão expõe também uma superfície irregular formada por camada de arenito conglomerático, intensamente deformado com micro - dobras irregulares, deitadas. A camada intercalase no diamictito, entre os dois niveis estriados. Em alguns casos foi possível medir a orientação dos eixos das dobras, SE e NW, com vergência para o norte, grosseiramente normais, portanto, às estriações. 


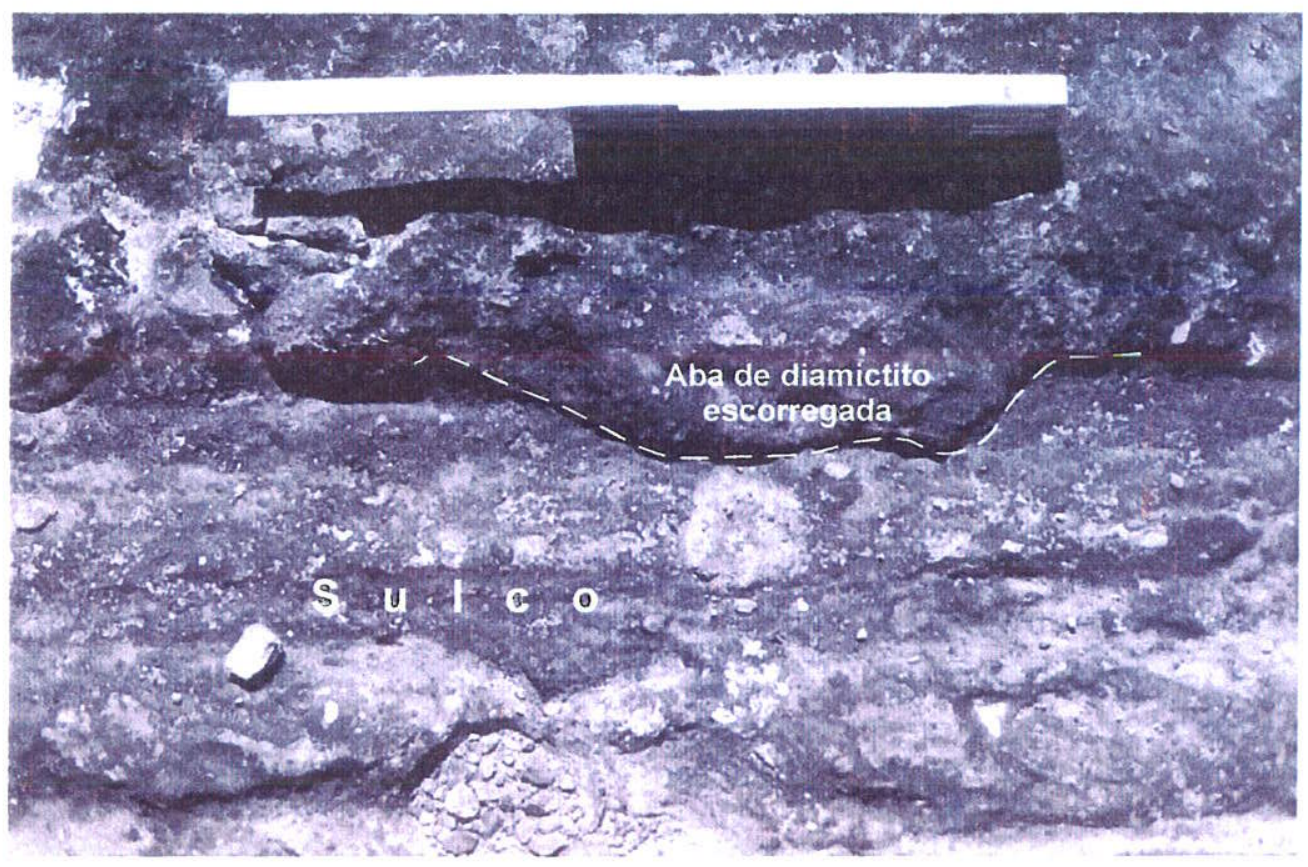

Figura III-12: Aba de diamictito escorregado dentro de sulco a partir de crista (lado superior da foto). A estrutura indica estado inconsolidado do substrato quando da abrasão glacial. Superfície superior.

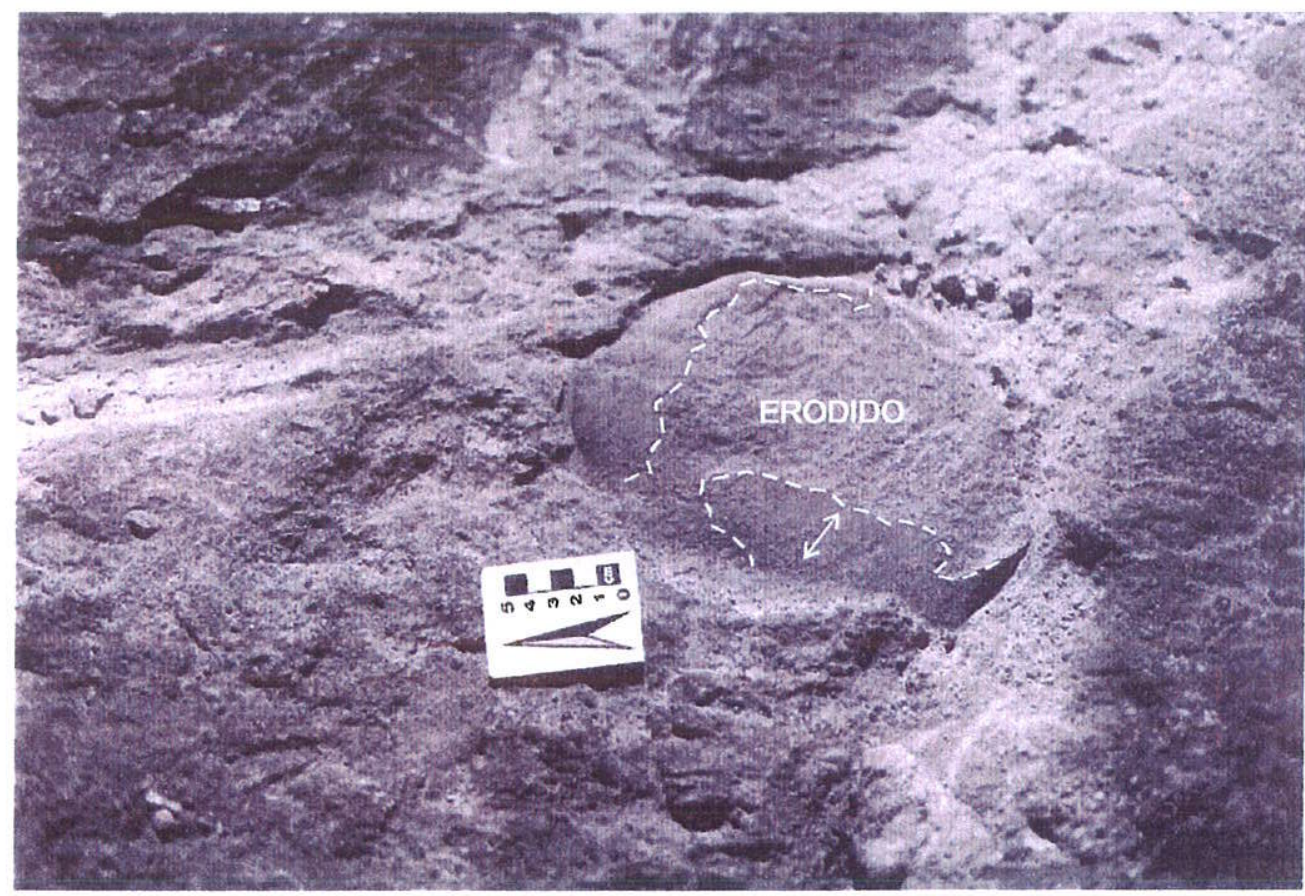

Figura III-13: Clasto embutido em diamictito no fundo de sulco, com topo truncado e estriado (margens do clasto). Seta indica a localização das estrias. Superfície superior. 


\section{Formas deposicionais ou construcionais}

Alguns exemplos de cristas que separam sulcos em São Luis de Purunã são morfologicamente semelhantes as cristas de till ou flutes, forma de terreno subglacial comum em regiões deglaciadas do Pleistoceno e Recente.

As cristas, formadas por diamictito, têm tipicamente comprimento de vários metros (até pelo menos $10 \mathrm{~m}$ ), largura decimétrica $(35-40 \mathrm{~cm}$ ) e altura de $20-30 \mathrm{~cm}$. Seu perfil retangular, de topo plano, exibindo estrias paralelas, difere do perfil típico das cristas de till do Pleistoceno. Um a dois matacões, às vezes representados por seus clastos, ocorrem adjacentes a uma das extremidades das cristas, com altura e largura próximos às delas (Fig. III-14). Algumas cristas afinam-se ao se distanciarem dos clastos. A despeito das dimensões relativamente pequenas, as características coadunam-se com as das cristas de till descritas na literatura (Gordon et al., 1992; Bennett e Glasser, 1996).

A origem de formas de terreno subglaciais do tipo flute está ainda envolta em relativa controvérsia, conforme se depreende da extensa bibliografia disponivel (e.g., Gordon et al., 1992; Hart e Smith, 1997). Flutes ou cristas de till são pequenas elevações que se alongam na mesma direção de fluxo do gelo. Uma das teorias mais aceitas afirma que a gênese dessas estruturas está relacionada a presença de grandes matacões ou obstáculos no substrato. O fluxo do gelo produz uma zona de baixa pressão (ZBP) atrás do obstáculo, e, como ao redor dessa ZBP existem zonas de alta pressão (ZAP), o sedimento pode fluir ao longo desse gradiente - alta pressão para baixa - formando a estrutura. São tipicamente compostos por till de alojamento, embora possam também conter areias fluviais e cascalho. Essas feições também são ótimas indicadoras de fluxo de geleira (Bennett e Glasser, 1996), no presente caso, de S-N.

Em alguns locais, seixos são acompanhados por sulcos duplos, separados por cristas baixas, lembrando estrias do tipo grampo de cabelo (hairpin). (Fig. I11-15.) Uma descrição detalhada dessa estrutura pode ser encontrada em Shaw (1994). Este tipo de estrutura poderia ainda corresponder a um mini-flute, cuja interpretação melhor se encaixa as características reológicas do substrato (soft bed), pois estrias do tipo grampo de cabelo se formam, normalmente, sobre substrato consolidado. 


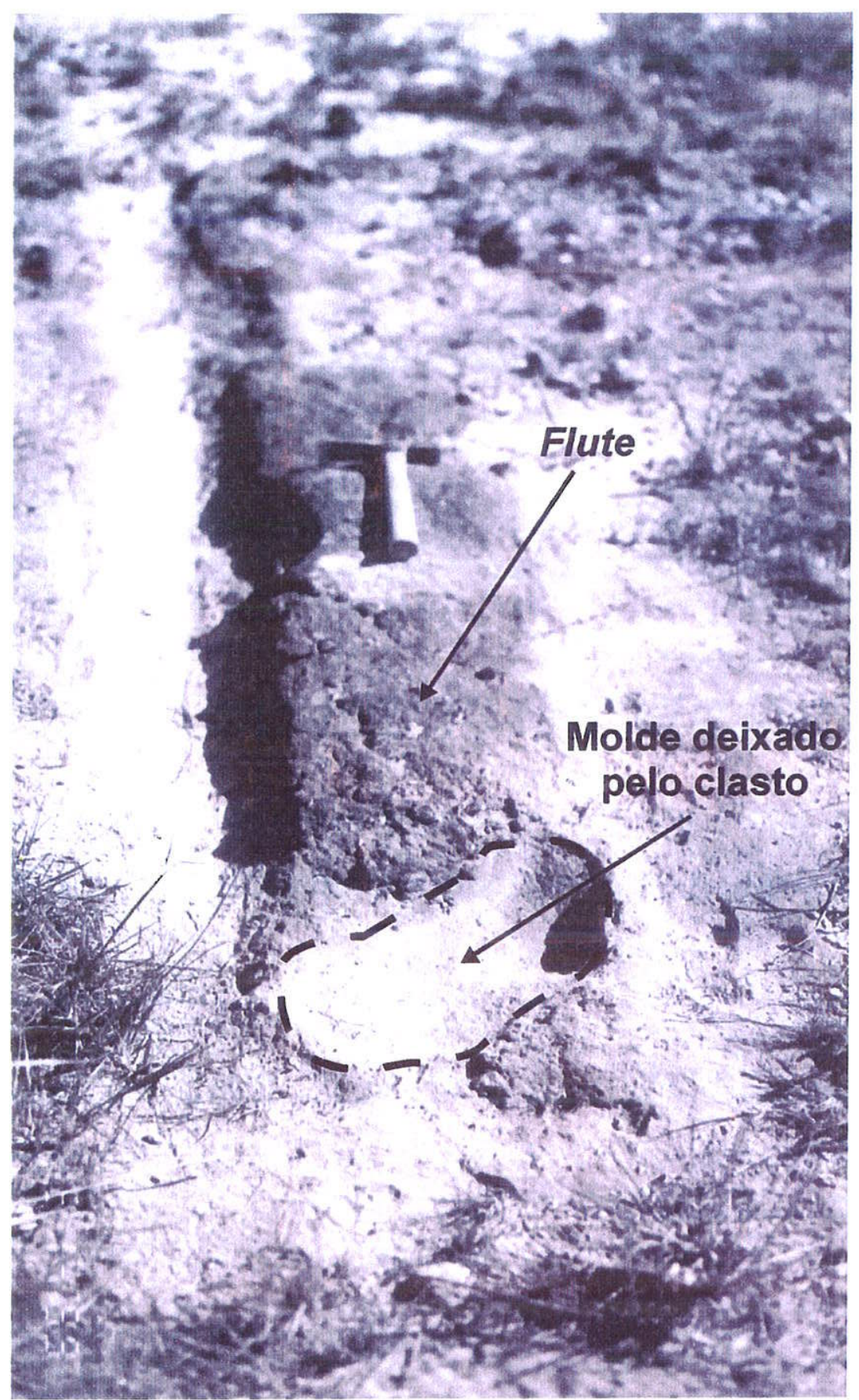

Figura III-14: Crista de sedimento depositado a jusante (na sombra) de clasto. Sentido de movimento do gelo de baixo para cima. A crista pode corresponder a um tipo de crista de till (tilito) ou flute. Superfície superior. 


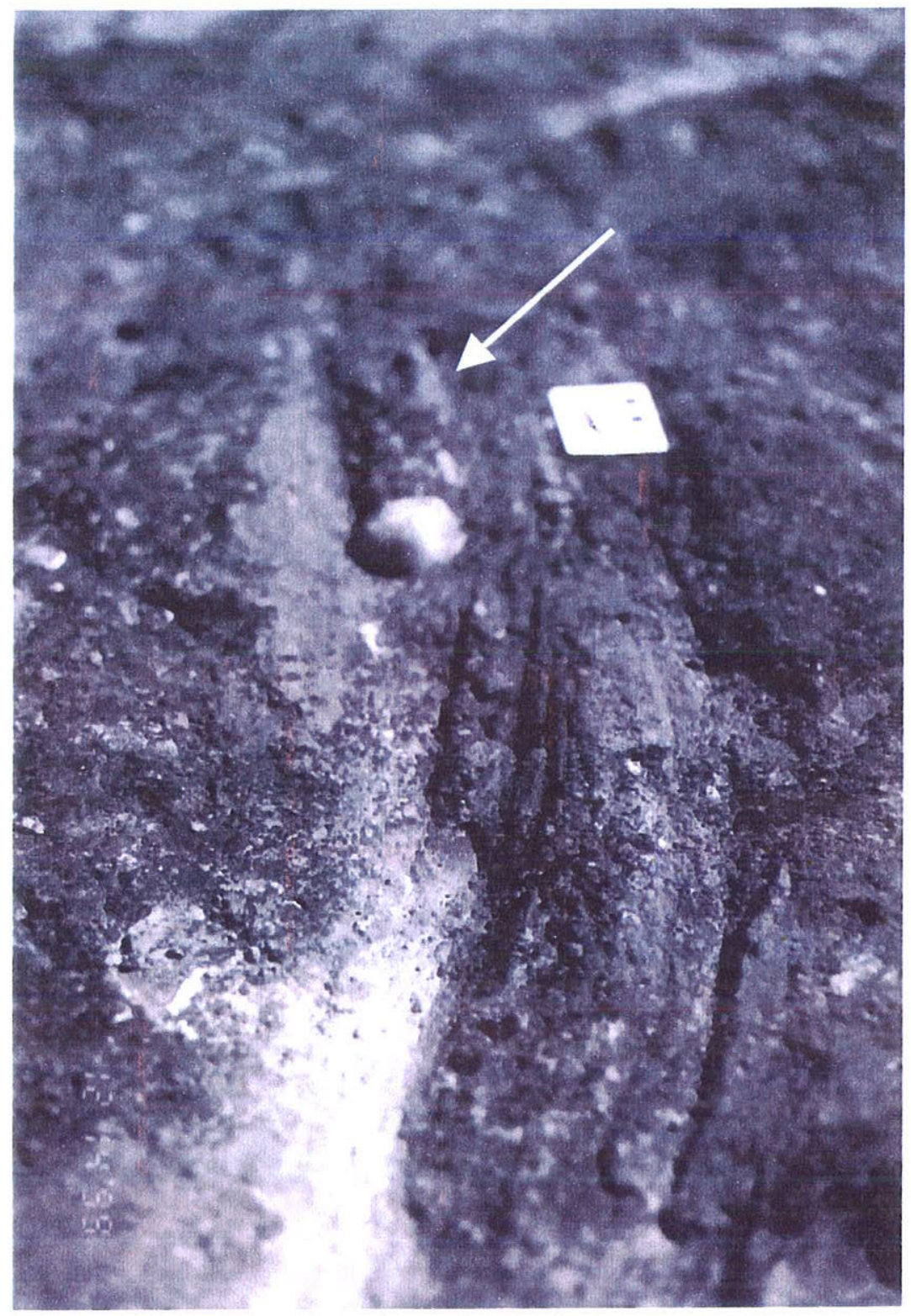

Figura III-15: Estrutura geometricamente semelhante a mini-flute. Notar clasto alojado no início da estrutura (obstáculo) e inflexão dos sulcos. Seta indica posição de mini-flute. Fluxo glacial de baixo (sul) para cima (norte) Superfície superior

Além das acima descritas, várias outras feições erosivas e deposicionais menores foram notadas em associação com as estriações. Algumas delas são, entretanto, pouco nítidas e de identificação imprecisa, dado o grau de intemperismo e erosão atual do afloramento. Incluem-se aqui corrugações paralelas, transversais, dentro de sulcos, que sugerem contato interrompido do agente erosivo com o substrato. Conjunto de clastos embutidos no diamictito, no fundo de sulco largo e de topo, possivelmente, truncado, formam um tipo de pavimento de clastos. Os eixos maiores destes, grosseiramente paralelos, têm direção N27E. 


\section{Origem e preservação}

As características discutidas apontam inequivocamente para o estado inconsolidado do diamictito durante o processo erosivo e a origem subglacial das estruturas no quadro da história geológica do Subgrupo Itararé. Essa associação e as características do diamictito indicam tratar-se de tilito de alojamento. As intercalaçóes arenosas deformadas representam, provavelmente, depósitos de água de degelo subglacial erodidas e deformadas pela reativação da deposição de till (Eyles, 1993).

O paralelismo das estrias e sulcos das superfícies indica que cada uma dela foi produzida durante um único evento erosivo. Este ter-se-ia repetido algumas vezes em intervalos relativamente curtos, a julgar pela pequena espessura de sedimentos que separa as estruturas, semelhante ao caso das superfícies estriadas de Palmeira.

Como se depreende dos conceitos discutidos anteriormente, a ocorrência de alojamento requer uma camada subglacial rígida, sobre a qual os detritos englaciais possam ser agregados. Outro processo subglacial importante, visivel no afloramento, é a ocorrência de aração (plowing) do till subglacial por clastos, posteriormente alojados sobre o substrato inconsolidado. Aração é um mecanismo erosivo subglacial no qual uma substância mais dura escava ou sulca uma substância mais mole (Drewry, 1986). O processo ocorre, por exemplo, quando um clasto transportado na base do gelo entra em contato e desliza sobre rocha da mesma composição (e dureza) ou sobre um substrato "mole", como é o caso das superfícies de São Luis de Purunã.

Clark e Hansel (1989) associam a aração ao processo de deposição subglacial de sedimentos através do alojamento. Este tem lugar quando a força imposta pelo fluxo do gelo é inferior a fricção do clasto sobre o substrato, inibindo o seu movimento. $O$ retardamento do movimento de clastos grandes gera o desenvolvimento de acumulação de clastos por alojamento. Segundo Drewry (1986) a aração predomina no caso do substrato da geleira ser composta de materiais deformáveis, como é o caso das superfícies estriadas de Palmeira, de São Luís de Purunã e outras encontradas na área de estudo.

Os elementos acima discutidos (Formas deposicionais ou construcionais) sugerem que as cristas de till possam representar um tipo de flute subglacial. Uma diferença que pode ser significativa em termos dos processos subglaciais envolvidos refere-se à morfologia mais regular das cristas de São Luís de Purunã, com perfil retangular e superfície relativamente lisa e estriada.

A morfologia mais regular ("alisada") das cristas de São Luís de Purunã e a presença de estrias pode sugerir terem sido elas em parte moldadas em contato com a base deslizante da geleira. Um tanto especulativamente sugere-se que o acúmulo linear 
de sedimento possa ter resultado da presença de obstáculo e da compressão lateral causada pelos clastos que sulcaram o diamictito na base da geleira.

Um pouco mais problemática é a natureza das cristas menores. Embora a sua formação possa envolver processo similar, é possivel, alternativamente, que representem feições erosivas do tipo estria em grampo de cabelo, em razão da presença de dois sulcos laterais ao clasto embutido na sua extremidade a montante. Hairpin é a combinação de sulco em crescente e duas estrias/sulcos paralelos. Sua gênese está relacionada a anteparos (obstáculos) do substrato e erosão por fluidos turbulentos, denominados de vórtices ferradura de cavalo (horseshoe vortices).

Embora a questão da origem das superfícies estriadas de São Luís de Purunã seja, em principio, mais fácil de entender do que a de Palmeira, alguns aspectos relacionados à preservação geológica das superfícies ainda não estão inteiramente esclarecidos, particularmente no caso dos afloramentos da superfície estriada superior.

O recobrimento do diamictito por uma camada de siltito laminado, que apresenta clastos caídos milimétricos, indicando recuo da frente glacial, sugere novamente a possibilidade de preservação dessas estruturas sob depósitos lacustres e/ou marinhos. Este é intercalado por lobos arenosos, com estratificação sigmoidal e seguida de espessa seqüência de arenitos interpretados como de origem flúvio-deltaica (Fig. III-11).

Sendo assim, duas hipóteses podem ser aventadas quanto ao ambiente no qual a geleira atuou:

a) a geleira pode ter se deslocado subaereamente, neste caso os depósitos flúvio-deltaicos seriam pós-glaciais; $e$

b) subaquática, a geleira estaria aterrada em um corpo d'água, marinha ou lacustre.

A escolha de uma das duas hipóteses acima levantadas geraria, qual fosse a escolhida, muita controvérsia. Contudo, algumas caracteristicas não conclusivas devem ser apontadas:

a) facilidade e rápida destruição dessas feições, caso expostas à erosão;

b) grande extensão das superfícies;

c) o fato do ambiente subaquático (marinho ou lacustre) apresentar condições mais propicias a sua preservação;

d) inflexão de sulcos e cristas;

e) espessa sequência flúvio-deltaica cobrindo a superficie; e

f) ausência de deformações significativas no diamictito. 


\section{III.1.4 - Paisagem de abrasão superficial}

Os tipos e a distribuição superficial das formas de terreno glaciais acima discutidos, no flanco sul do arco de Ponta Grossa, permite caracterizar na região pelo menos dois tipos de paisagem glacial erosiva ou área de abrasão superficial, amplamente exumada e excelentemente preservada. As feições erosivas associam-se formas de terreno subglaciais deposicionais (flutes, morainas de empurrão etc.) e depósitos glaciais (diamictitos e rochas associadas) que configuram uma assembléia de formas de terreno sedimentos - do tipo subglacial (Eyles, 1993; Bennett e Glasser, 1996).

Assembléias com a extensão e riqueza de feições, como às aqui descritas, não são conhecidas na literatura de Geologia Glacial pré-pleistocênica. Não encontram também paralelo no registro glacial pleistocênico e recente (Prof. Dr. Matthew R. Bennett, informação verbal). A sua ocorrência e preservação resultam da conjugação de fatores geológicos, especialmente de natureza tectônica, durante o neopaleozóico e posteriormente discutidos no Capítulo $\mathrm{V}$.

Estudos realizados em regiões glaciadas no Pleistoceno e recentes indicam que as formas de terreno erosivas e deposicionais têm sua distribuição controlada por variações de condições que ocorrem nas geleiras, tanto espacial quanto temporalmente, entre elas: velocidade, espessura, regime térmico, balanço de massa, geologia e topografia do embasamento. O reconhecimento da ocorrência recorrente de diversos tipos de assembléias de formas de terreno, abre a possibilidade de a partir do seu estudo tentar caracterizar aspectos glaciológicos de geleiras antigas.

Este tipo de estudo é praticamente inexistente no caso de depósitos glaciais prépleistocênicos, por causa das limitações do registro geológico. A área do arco de Ponta Grossa oferece uma rara oportunidade de interpretar características do manto de gelo de Windhoek (Santos et al., 1996), em particular do lobo glacial Paraná que teria afetado a região. Esses aspectos serão desenvolvidos com mais pormenores mais adiante (Cap. VI).

No presente capitulo pretende-se chamar a atenção para as características mais notáveis que tornam a área de estudo um local de excepcional importância para estudos de Geologia Glacial. As caracteristicas mais relevantes das assembléias de formas de terreno glaciais de erosão e deposição da área de estudo, neste caso, são as seguintes:

a) a paisagem inferior mostra a ausência generalizada de formas de terreno de erosão glacial positivas do tipo formas alongadas moldadas e montante - jusante (dorsos de baleia, drumlins rochosos, rochas moutonneés etc.). O avanço inicial do lobo Paraná sobre a área de estudo ocorreu sobre substrato de rochas consolidadas ("duras"), 
paleozóicas (arenito Furnas), aplainado pela erosão pré-Itararé (superfície de discordância).

Superfícies de erosão glacial planas sobre substrato litificado (cristalinos e sedimentares) não são usuais, porque as geleiras tendem a explorar linhas de fraqueza sob a forma de juntas e falhas. Consequentemente, algum relevo deve ser esperado (Cap. V).

Como veremos, superfícies de erosão extensas desenvolvem-se sob a forma de paisagem de abrasão superficial sob geleiras de base quente e mostram estriação generalizada, no geral associada a rochas mountonneé, dorsos de baleia etc. Conforme discutido mais adiante, a topografia inicial plana, a uniformidade e estratificação plana do arenito do substrato, condicionaram a formação dessa superfície.

b) em fase posterior, a geleira neopaleozóica deslizou sobre substrato formado por sedimentos do Subgrupo Itararé (arenito e diamictitos). A ação glacial deu-se então sobre embasamento inconsolidado, deformável, heterogêneo e de características reológicas distintas do substrato anterior, conforme pode ser constatado pelas formas de terreno associadas.

Embora a este evento possa estar associada à formação de uma paisagem de erosão e deposição distinta da anterior, a dificuldade de correlacionar estratigraficametne as diferentes exposições, torna a sua identificação menos clara. As evidências disponiveis indicam que elas foram formadas sobre depósitos pró-glaciais, flúvio-glaciais e de till relacionado com evento glacial inicial.

Formas de terreno erosivas são, ainda, feições de ocorrência generalizada sobre rochas sedimentares do Subgrupo Itararé. Formas deposicionais (construcionais) descritas em vários locais (São Luís de Purunã; afloramentos junto ao rio Cancela), embora em posição estratigráfica variável, exemplificam tipos de formas de terreno deposicionais que caracterizam esse tipo de paisagem glaciada, caracterizando uma assembléia de formas de terreno - sedimento subglacial (Eyles, 1993) associada à ação de geleira de base quente (Cap. VI). A despeito da natureza inconsolidada e, portanto, deformável do substrato glacial, evidências de deformação intensa não foram encontradas, com exceção de arenito conglomerático, dobrado, de São Luis de Purunã.

\section{III.2 - Formas de terreno construcionais}

Afloramentos junto ao rio Cancela

Deformação glaciotectônica tem lugar sempre que o esforço imposto pela geleira em movimento excede a resistência do material subjacente ou situado a sua frente. $A$ ocorrência de camadas sedimentares deformáveis (deforming beds) sob e à frente de 
geleiras e o seu efeito sobre a dinâmica das massas de gelo constitui um dos problemas mais atuais da Geologia Glacial e Glaciologia (Boulton e Hindmarsh, 1987). Outros aspectos pertinentes para o entendimento do fenômeno envolvem o regime térmico basal das geleiras, a reologia, regime hidráulico e topografia do substrato sobre o qual a geleira se move (Boulton e Hindmarsh, 1987; Boulton, 1993; Bennett e Glasser, 1996; Benn e Evans, 1998).

O exame desses tópicos em depósitos glaciais antigos, no caso, neopaleozóicos, constitui, como já exposto, o objetivo principal da presente dissertação.

Deformações glaciotectônicas podem ser geradas na frente (proglaciais) ou embaixo (subglaciais) de geleiras em movimento. Os dois tipos são, na verdade, transicionais e podem incluir deformações do tipo rúptil (falhas, fraturas, acavalamentos) e dúcteis (dobras).

Deformação glaciotectônica produzida proglacialmente leva à formação de diversos tipos de acumulações de sedimentos, rocha e gelo, pela ação de bulldozer (=terraplanagem) da geleira sobre material proglacial que forma cristas, denominadas morainas glaciotectônicas, paralelas à frente da geleira.

O prosseguimento do avanço da geleira provoca contínuas modificações no padrão de deformação sofrido pelos detritos glaciais. Deformação do tipo subglacial inicia-se quando a geleira sobrepassa esses depósitos, resultando em intensificação do esforço deformante de cisalhamento.

Os tipos de estruturas de deformação variam de acordo com o nível de cisalhamento atingido. Sedimentos submetidos a alto grau de cisalhamento tornam-se completamente misturados e homogeneizados, com destruição de estruturas sedimentares originais. O produto final é um material com aspecto de diamictito, constituindo um tipo de till subglacial chamado de till de deformação (Elson, 1988).

Um dos tipos mais comuns de morainas glaciotectônicas é formado pelas morainas de empurrão (push moraines). Constituem elas cristas compostas tipicamente de till subglacial, mas sedimentos de lavagem (outwash) e outros detritos proglaciais podem também ocorrer. Formam cristas de $1-5 \mathrm{~m}$ de altura, no geral de perfil assimétrico em seção (menos inclinadas a montante e mais inclinadas a jusante) e de forma lobada em planta, distribuidas em faixas arqueadas grosseiramente paralelas à margem frontal das geleiras.

Geleiras em recesso, porém sujeitas a avanços curtos sazonais (outono-inverno), formam conjuntos de morainas de empurrão anuais (Fig. III-16). O avanço contínuo, por outro lado, pode levar a formação de morainas de empurrão compostas, pela justaposição ou acavalamento de cristas. 


\section{Facies sedimentares associadas com pequenas morainas de empurrão sazonais}

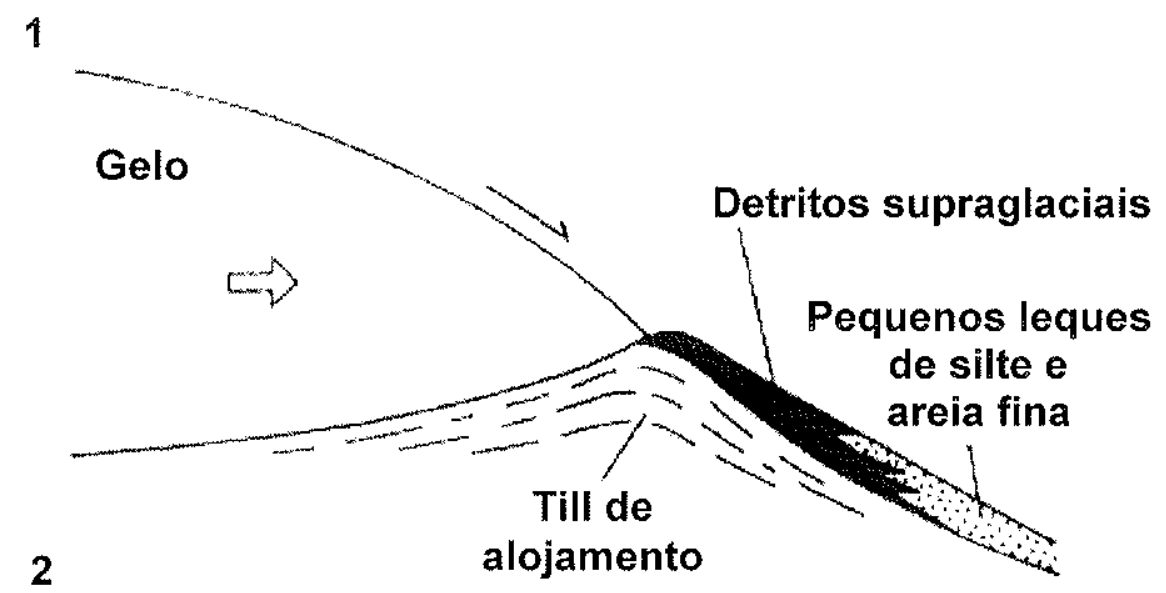

Suplimento contínuo de detritos supraglaciais

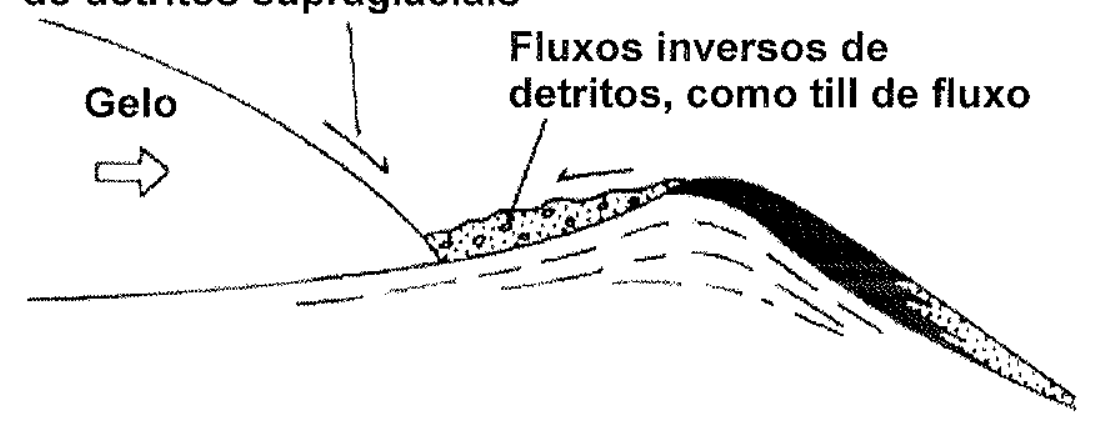

3

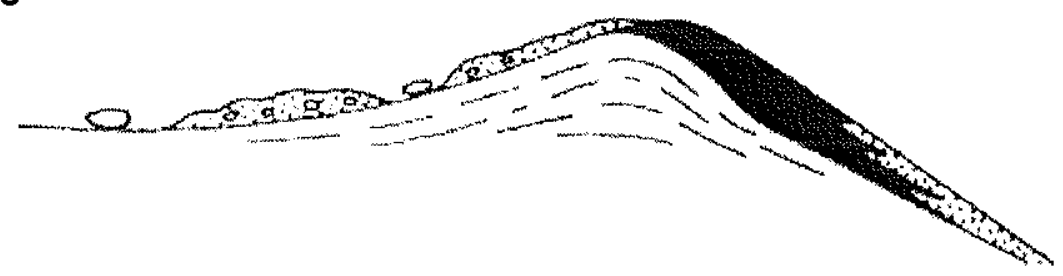

Figura III-16: Morainas de empurrão sazonais. Facies sedimentares normalmente associadas às morainas de empurrão sazonais (Bennett e Glasser, 1996). Notar pequenos leques de silte e areia fina e escorregamentos de till de fluxo em direção a geleira. Muitas das facies acima descritas são encontradas na Colônia Witmarsum.

Vários tipos de estruturas constituidas de diamictito, encontradas na área da colônia de Witmarsum, assemelham-se a morainas de empurrão. Essas incluem: a) estruturas anticlinais; e b) colinas dômicas. 


\section{- Estruturas anticlinais}

Essas estruturas formam série de anticlinais de diamictito e arenito, com cerca de $1,2 \mathrm{~m}$ de altura e $6 \mathrm{~m}$ de largura, expostas em afloramento situado a aproximadamente $100 \mathrm{~m}$ a oeste da Companhia de Laticínios Cancela. As estruturas anticlinais afloram ao longo de corte vertical de orientação E-W, com cerca de $40 \mathrm{~m}$ de comprimento, que expõe a estrutura interna das feições. Cinco a seis anticlinais podem ser reconhecidos, os três últimos, na extremidade oeste do corte, sendo mais nítidos (Fig. III-17).

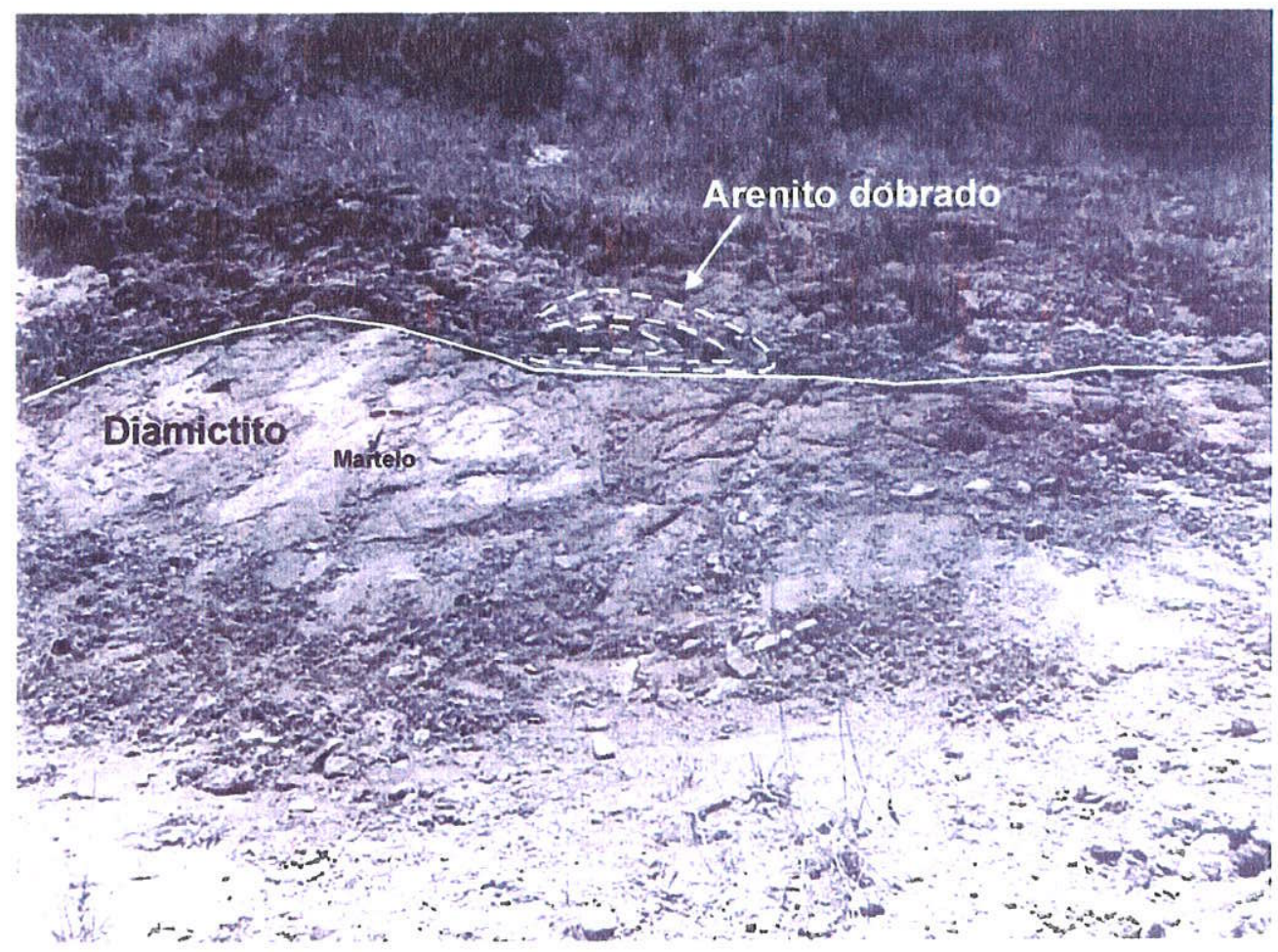

Figura III-17: Visão geral de parte do afloramento. Na porção superior há um corpo de arenito médio exibindo dobra recumbente. A parte inferior do afloramento consiste de diamictito arenoso, estratificado, com clastos $\mathrm{cm}$ a dm. Afloramento atrás da Companhia de Laticínios Cancela (Unidade 2, Anexo 1).

Pelo menos dois corpos distintos de diamictito arenoso, vermelho e cinza, constituem o núcleo dos anticlinais. Camadas centimétricas de arenito grosso intercalamse nos diamictitos e capeiam as estruturas. Os anticlinais exibem intensa e complexa deformação interna, sob a forma de dobras deitadas aparentemente rompidas lateralmente por falhas e fraturas, que provoca certa mistura dos diamictitos. 
Limonitização intensa das camadas de arenito torna-as mais resistentes, ressaltando-as no afloramento e permitindo melhor visualização da estrutura interna e forma dos anticlinais. Camadas de arenito que capeiam as estruturas estão complexamente dobradas e redobradas (Fig. III-18). Estes parecem ter vergência para oeste, ao longo do corte. Outras estruturas secundárias notáveis no afloramento são diques clásticos verticais, compostos de arenito grosso limonitizado e diamictito intercalado que cortam verticalmente o afloramento. As dimensões gerais e orientação das estruturas, o seu confinamento às litologias do Subgrupo Itararé, permitem separalas claramente das deformações relacionadas ao falhamento Cancela, que corre cerca de $30 \mathrm{~m}$ ao norte do afloramento das anticlinais.

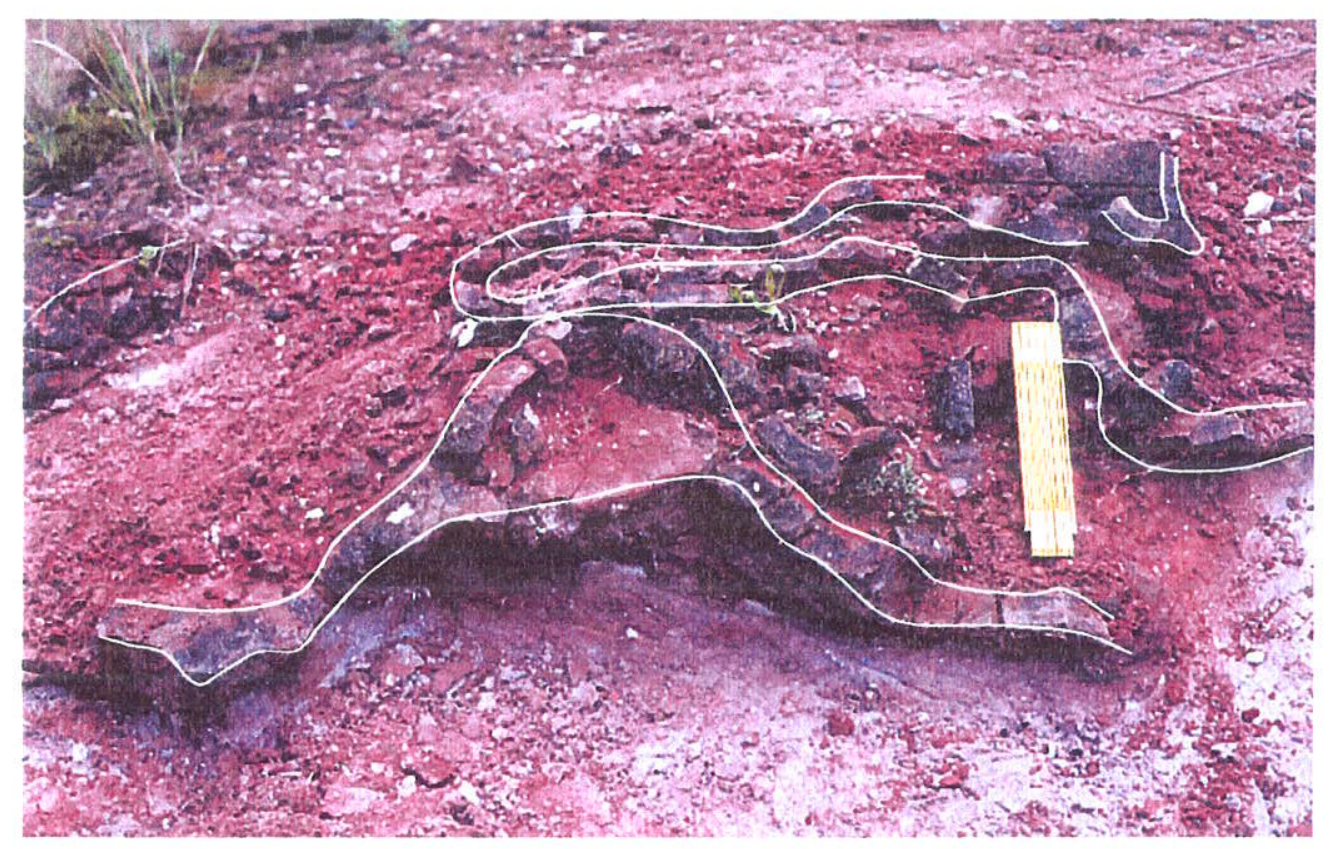

Figura III-18: Camadas de arenito médio, limonitizado, intensamente dobradas e redobradas capeando os anticlinais de diamictito. Afloramento atrás da Companhia de Laticínios Cancela (Unidade 2, Anexo 1).

O estilo predominantemente dúctil e subsidiariamente rúptil das deformações é outra característica a ser destacada neste afloramento (Fig. III-19). As características dos anticlinais aproximam-nos de feições geomórficas proglaciais do tipo morainas deformadas ou de empurrão glacial (push moraines) 


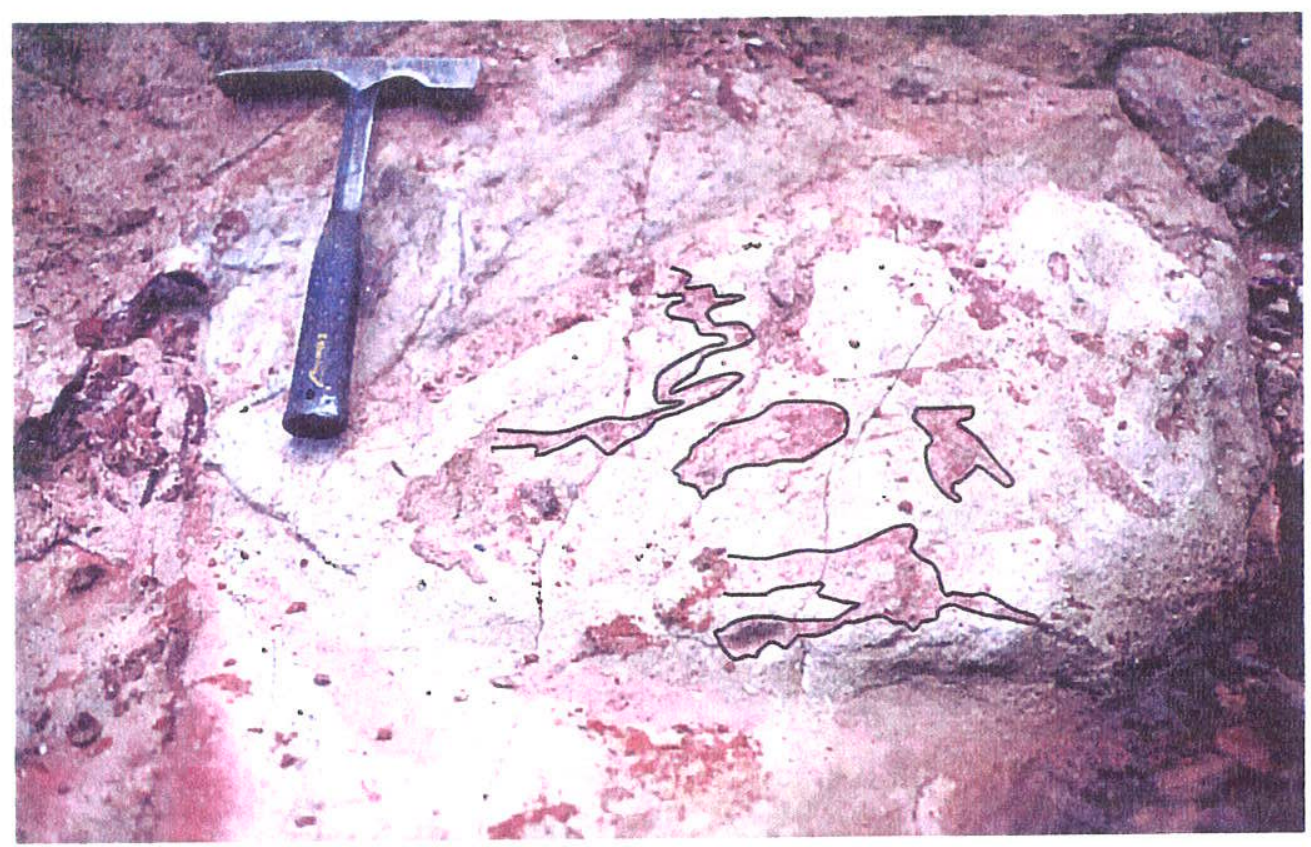

Figura III-19: Diamictito branco, matriz síltica com clastos de diamictito vermelho. Notar aspecto plástico dos clastos, inclusive com pequenos dobramentos, sugerindo estado inconsolidado quando da deformação. Afloramento atrás da Companhia de Laticínios Cancela (Unidade 2, Anexo 1).

- Colinas dômicas de diamictito

Outras estruturas similares as anteriores, melhor preservadas, afloram a cerca de $1,5 \mathrm{~km}$ ao sul do último afloramento descrito. As estruturas ocorrem sob a forma de colinas baixas, alongadas na direção E-W, agrupadas descontinuamente ao longo de pelo menos três faixas paralelas, distintas, até $250 \mathrm{~m}$ de extensão, separadas entre si por regiões mais ou menos planas. As dimensões individuais variam de 3-8 $\mathrm{m}$ de altura por $30 \mathrm{~m}$ de extensão. As formas das colinas em planta não podem ser perfeitamente identificadas em fotos na escala 1:25.000, mas parecem lobadas. Têm perfil arredondado e assimétrico, com o flanco sul mais suave e norte mais abrupto. Os topos das estruturas estão parcialmente cobertos por camadas descontínuas de arenito fino, endurecido e deformado, o que poderia explicar a preservação da forma tridimensional das colinas (Figs. III-20 e III-21).

As estruturas elevam-se sobre o flanco sul do vale do rio Cancela, assentando-se sobre superfície de terreno com declive de cerca de $4^{\circ}$ para o norte. As faixas de colinas dispõem-se, pois, escalonadamente, situando-se cada vez mais altas em direção sul. 


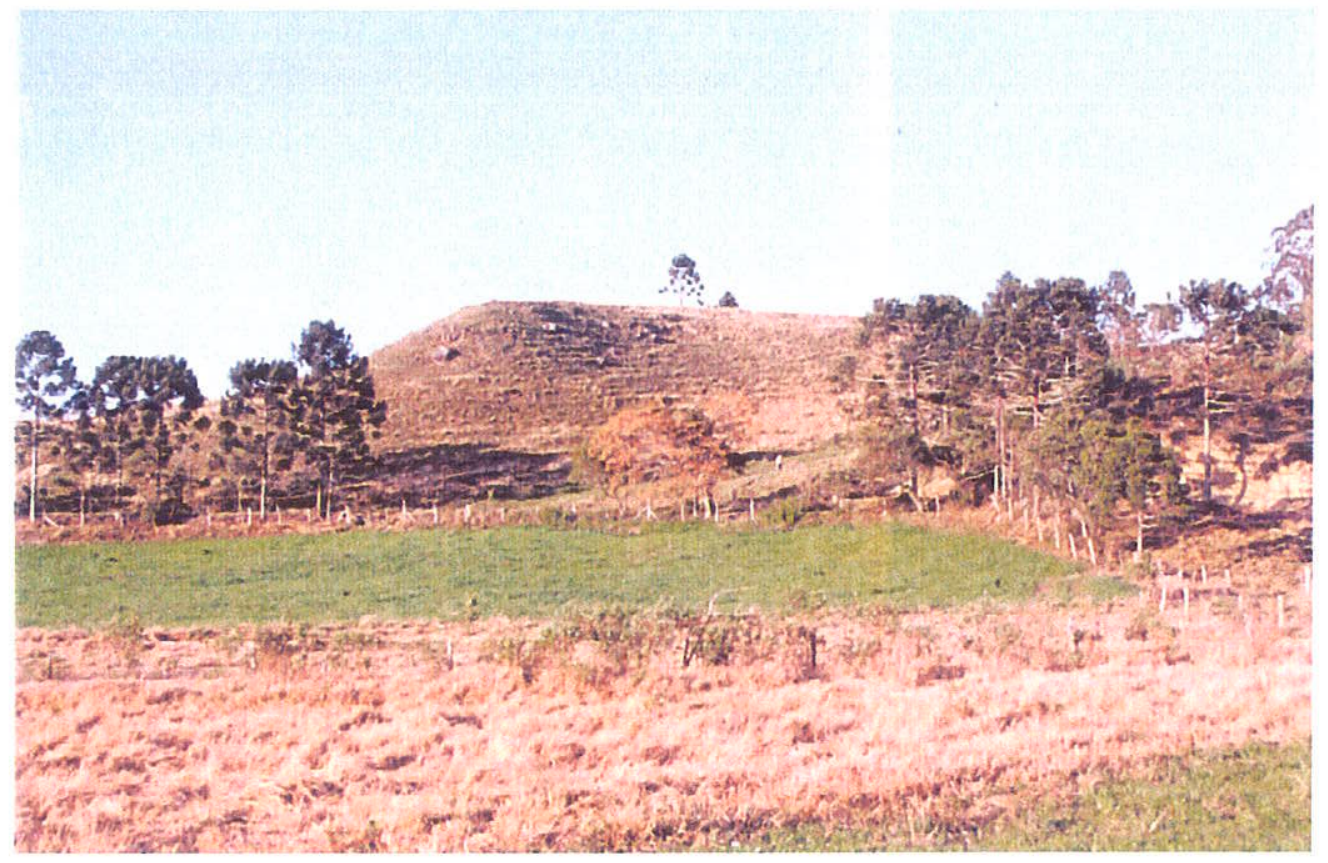

Figura II-20: Visão parcial de estrutura em forma de colina identificada na Colônia de Witmarsum (PR). O topo da colina está coberto por arenitos finos, que ajudaram preservar a estrutura em sua forma original. Foto tirada de sul para norte.

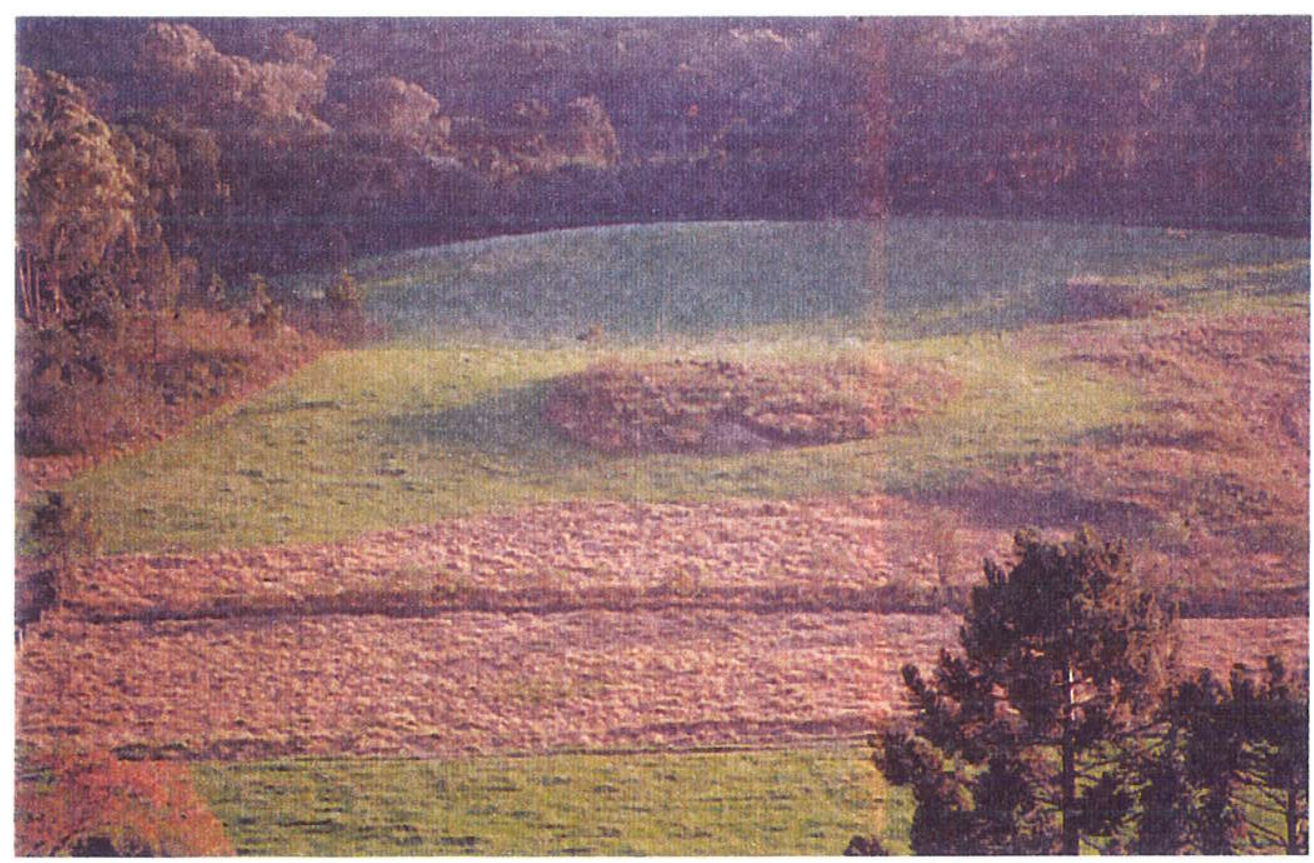

Figura III-21: Pequena colina formada por diamictito arenoso deformado. As colinas apresentam geometria, forma e estrutura interna compatíveis com morainas de empurrão. Foto tirada de norte par sul, sobre colina mostrada na Figura III-20. 
Tanto as colinas, quanto o terreno que as separa são constituídos de diamictito silto-argiloso maciço, com freqüentes clastos dispersos. Esses corpos mostram-se dobrados e com lentes centimétricas de arenito fino cisalhado, provavelmente ligados a depósitos supraglacias (till de fluxo). A estrutura e composição interna das colinas podem ser observadas em cortes artificiais para extração da rocha. A face vertical dos afloramentos têm orientação variada e permitem examinar cortes longitudinais/obliquos e transversais das estruturas.

A composição interna das estruturas é basicamente homogênea e constituida de diamictito arenoso, ocre e com clastos de tamanho $\mathrm{cm}-\mathrm{dm}$. Camadas de arenito de espessura métrica parecem restringir-se ao topo das estruturas, formando uma cobertura descontínua. Esse capeamento pode ter protegido as colinas da erosão, preservando sua forma.

A estrutura interna das colinas, em corte oblíquo ao seu eixo, caracteriza-se pela presença de falhas reversas de vários tamanhos $(\mathrm{dm}-\mathrm{m})$ e de traço lístrico, fraturas e dobras de médio porte, deitadas. Raras inclusões de corpos de arenito fino, de até cerca de $1 \mathrm{~m}$ de comprimento e $30-40 \mathrm{~cm}$ de largura, podem também ser visto. Esses corpos podem estar relacionados a pequenos depósitos lacustres formados por acumulações de água de degelo entre as cristas. O diamictito está ainda cortado por juntas encurvadas de distribuição caótica e provável origem intempérica ou formadas por alivio de carga, que interferem na identificação das estruturas tectônicas. Embora no geral maciço, o diamictito pode mostrar-se estratificado em camadas $\mathrm{cm}-\mathrm{dm}$ subverticais nos flancos das estruturas (Fig. III-22 e III-23). Igualmente deformadas mostram-se as camadas de arenito de que cobrem o terreno sobre o topo e flancos das colinas. A deformação, com eixos orientados NNE-SSW, obscurece as estruturas sedimentares, que podem incluir estratificação cruzada.

As características acima, particularmente forma, composição, estruturas (dobras, falhas e fraturas) e por não apresentarem feições de cisalhamento subglacial, mostram que elas são inteiramente compativeis com as de morainas de empurrão descritas na literatura de Geologia Glacial do Pleistoceno e recente (Van der Wateren, 1995; Bennett e Glasser, 1996). A distribuição das estruturas em faixas paralelas, perpendiculares ao sentido do fluxo do gelo na área (Anexo 1), vem em apoio a essa interpretação.

As características e a disposição espacial das estruturas sugerem que elas podem corresponder a morainas de empurrão sazonais, formadas durante curtos avanços da frente da geleira, durante o outono-inverno, sobre a paisagem deglaciada, provocando o acúmulo de série de cristas de till subglacial e sedimentos flúvio-glaciais subsidiários, dispostas paralelamente à frente da massa de gelo. 


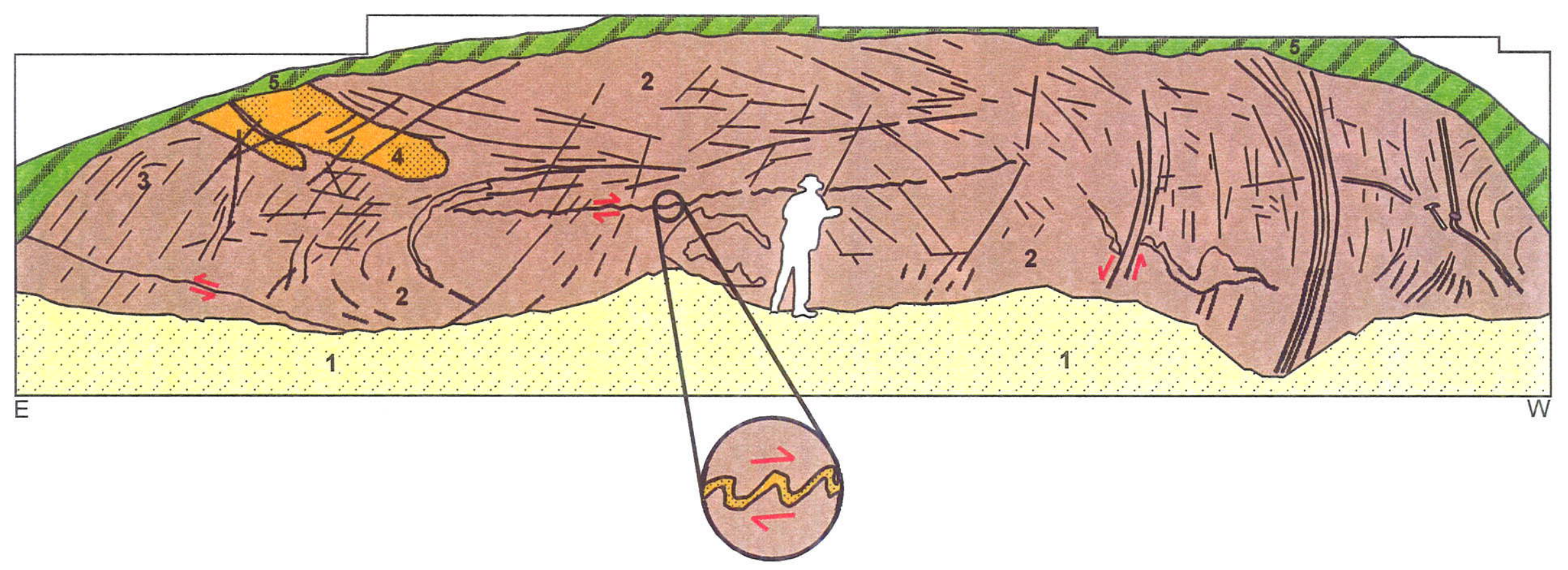

Figura III-22: Esquema de colina dômica de diamictito, corte obliquo. $O$ afloramento é cortado por grande quantidade de fraturas e falhas normais e reversas. Notar geometria alongada do afloramento, que, conjuntamente com as estruturas, coadunam-se com a interpretação de moraina de empurrão. 1 = encoberto; 2 = diamictito de matriz arenosa; 3 = camadas inclinadas de diamictito escorregado; 4 = arenito fino com clastos embutido no diamictito; e 5 = vegetação (A. Tomio, em preparação). 


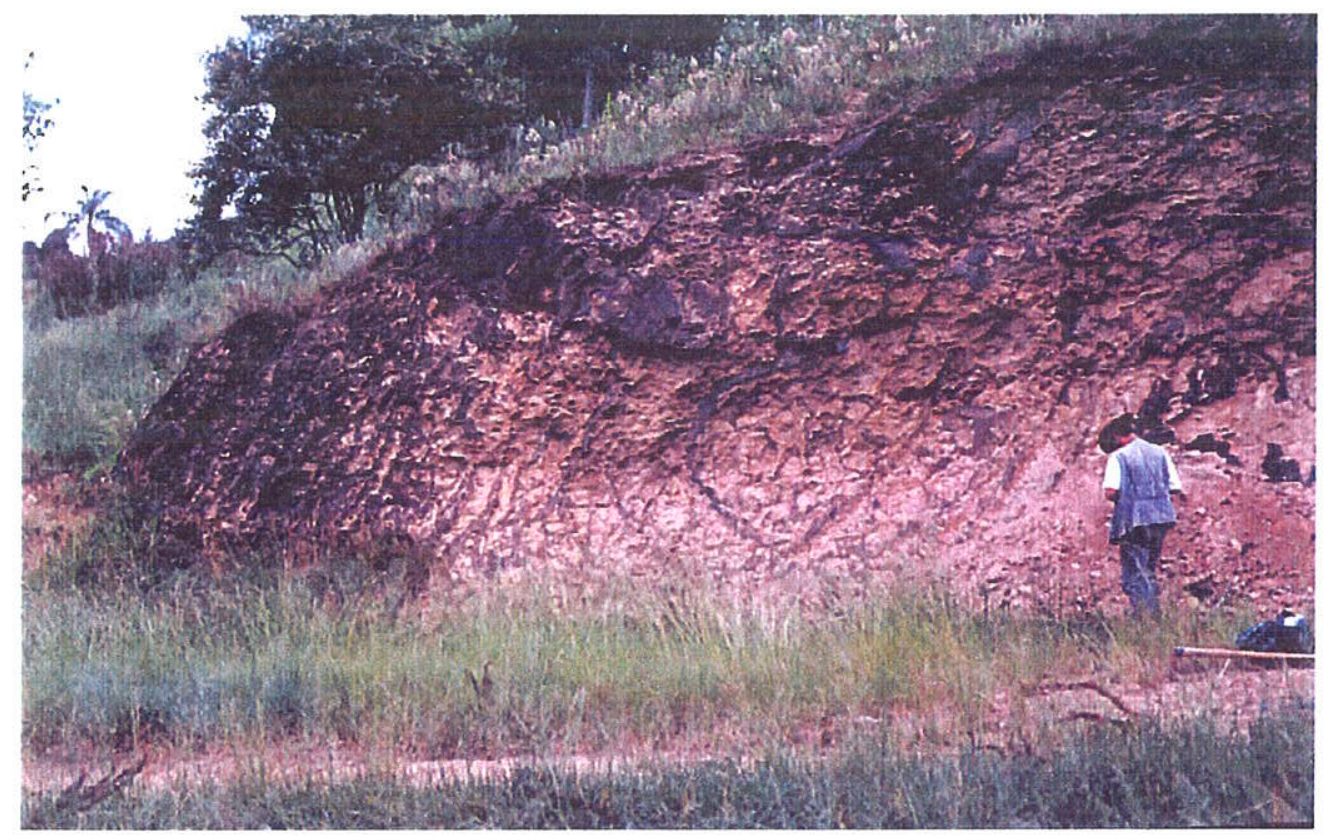

Figura III-23: Foto na porção esquerda do esquema mostrado na Figura III-22. Notar intenso fraturamento e falhas normais e reversas de pequeno porte associadas. Observar na porção à esquerda da fotografia depósito formado por escorregamento, que ocorre freqüentemente nas porções laterais das morainas de empurrão (Unidade 2, Anexo 1).

A possibilidade de preservação de feições geomórficas em depósitos glaciais prépleistocênicos, constitui fato extremamente raro e de grande repercussão no âmbito da Geologia Glacial. Na verdade, não há atualmente na literatura internacional referência à ocorrência deste tipo de estrutura em sucessões glaciais antigas. 


\section{IV - DEPÓSITOS GLACIAIS DO SUBGRUPO ITARARÉ EM WITMARSUM, PR}

A ampliação do conhecimento geológico da área de estudo e, particularmente, o exame pormenorizado de afloramentos na área da Colônia Witmarsum, onde ocorre o célebre pavimento estriado (Bigarella et al., 1967), levou a uma série de novas descobertas relacionadas à estratigrafia glacial, de grande relevância para a presente pesquisa.

De particular importância foi a constatação da presença de grande número de camadas de diamictitos de características distintas e de litofacies e feições associadas ao domínio terrestre da glaciação, intercalados como outras litofacies indicativas de condições marinhas. A complexidade litológica da sucessão e de seu condicionamento tectônico exigiu, para o seu melhor entendimento, a confecção de mapa geológico de detalhe.

\section{IV.1 - Mapeamento Geológico}

A estratigrafia do Subgrupo Itararé examinada mostrou-se mais complexa e variada do que o inicialmente previsto e representado no mapa de Fuck et al. (1965), Folha de Quero-Quero, em especial no que diz ao número, às características dos diamictitos, suas relações mútuas de contato e com outras rochas associadas aflorantes, predominantemente arenosas. A intervenção de falha de orientação SW$\mathrm{NE}$ afetando o pacote sedimentar e sua estratigrafia, e as evidências de regime compressivo e transpressivo dos esforços causadores dessas estruturas exigiram uma análise mais cuidadosa desse aspecto da geologia regional, os quaís já foram tratados no Capítulo 1.3.1.

Além dos diamictitos, outras facies glaciais de provável origem glácio-lacustre e flúvio-glacial, formas de terreno sugestivas de feições proglaciais, supraglaciais e de colapso foram também observadas nas fotos aéreas e em afloramento. Todos esses elementos sugerem que o Subgrupo Itararé, provavelmente, inclui depósitos e formas de terreno glaciais, hoje exumados, inclusive alguns inéditos no registro prépleistocênico.

A geologia da área mapeada é constituída de rochas sedimentares da Formação Furnas (Devoniano) e do Subgrupo Itararé (Permo-Carbonífero). (Anexo 1.) 


\section{DEVONIANO INFERIOR}

\section{Formação Furnas}

- Unidade 1 (Embasamento)

Arenitos da Formação Furnas formam o embasamento local do Subgrupo Itararé e só foram estudadas sumariamente. São arenitos finos a médio-grossos, quartzosos, freqüentemente feldspáticos, de pouca matriz e, no geral, mal selecionados. Formam bancos de espessura variando de $\mathrm{dm}-\mathrm{m}$, frequentemente mostram estratificação cruzada de porte médio a grande, tabular, tangencial na base e granodecrescência ascendente. Entre os bancos intercalam-se lentes e camadas centimétricas de siltito argiloso branco-esverdeado. Conforme apontado na literatura (Bigarella et al., 1967), nem sempre é fácil distinguir entre arenitos da Formação Furnas e do Subgrupo Itararé, quando imediatamente superpostos. O conjunto de características acima e diferenças na orientação das paleocorrentes entre as duas unidades permitiu a sua distinção na área.

\section{PERMO-CARBONIFERO}

Subgrupo Itararé (Unidades $2-5$ )

Compõe-se predominantemente de diamictitos e arenitos. A estratigrafia levantada baseia-se, além do mapa geológico (Anexo 1), na construção de algumas seçôes e perfis estratigráficos (Anexo 2 e Fig. IV-5). Com base nesses elementos, foi possivel ordenar a maior parte da sucessão litológica exposta na área mapeada. A correlação entre as sucessões expostas em outros pontos da área de pesquisa não está ainda inteiramente resolvida devido à pequena espessura de rochas geralmente expostas na maioria dos afloramentos, similaridade litológica entre os diamictitos e falta de camadas-guia regionais (a não ser, possivelmente, alguns dos diamictitos e camadas mais extensas de arenitos).

O perfil geológico exposto ao longo da estrada de ligação entre a Colônia Witmarsum e a BR-277, completado por outras seções estratigráficas levantadas, fornece uma visão geral da estratigrafia do Subgrupo Itararé na área da colônia.

No perfil levantado, a unidade tem cerca de $114 \mathrm{~m}$ de espessura exposta, consistindo de pacotes alternados de diamictito e arenito. Essa disposição resulta em topografia escalonada, com os arenitos sustentando pequenas escarpas, entre as quais intercalam-se regiões de relevo plano ou pouco inclinado, desenvolvidas sobre os diamictitos. 
- Unidade 2

É formada predominantemente por diamictitos e arenitos subsidiários.

Um grande número de diferentes corpos de diamictito, de espessura variando de decimetros a poucos metros, matriz arenosa, silto-arenosa a silto-argilosa e cores variadas (vermelho, branco, amarelo e cinza) foram identificadas. Variam eles de maciços a estratificados, desde grosseiramente até laminados ou "foliados" (estratificação descontínua) e cisalhados. (Figs. IV-1; IV-2.) Os clastos dispersos são no geral pequenos $(\mathrm{mm}-\mathrm{cm})$, raramente decimétricos.

A geometria dos corpos de diamictito é variada e inclui:

a) corpos tabulares, maciços a estratificados (grosseiramente, laminados e "foliados" = estratificação descontínua), de contatos bruscos e erosivos;

b) corpos maciços, irregulares, porém distintos, de contatos bruscos e complexamente interdigitados, deformados e intercalados por camadas $\mathrm{cm}-\mathrm{dm}$ de arenito fino, também complexamente dobradas. Esses conjuntos formam séries de anticlinais paralelos, de cerca de 1,2 $\mathrm{m}$ de altura e 2-3 $\mathrm{m}$ de largura, na parte basal do perfil;

c) corpos coliniformes de 4-5 $\mathrm{m}$ de altura por 5-8 $\mathrm{m}$ de largura, de diamictito maciço a bem estratificado, intercalado e capeado, respectivamente, por camadas de arenito fino e médio. O diamictito está deformado por falhas normais e reversas, fraturas e dobras.

Além das camadas de arenito deformadas, intercaladas nos diamictitos e capeando as estruturas anticlinais e coliniformes, um arenito ocre, branco e amarelo mais espesso (cerca de $5 \mathrm{~m}$ ), ocorre sobre diamictito, na parte superior da seção. Estratificação cruzada acanalada de pequeno porte e pequenas dobras de vergência para NW ou NE são comuns nessa unidade.

- Unidade 3

O pacote é constituído de bancos de arenito de características diversas, de até $10,84 \mathrm{~m}$ de espessura total, formando escarpa continua, mais visivel nos flancos do vale do rio Cancela.

Na seção aflorante no morro Siebert (Fig.IV-5), a unidade consta de 3 pacotes de arenito, contendo uma camada fina ou lente de diamictito intercalada, de baixo para cima:

a) arenito grosso, branco, com estratificação cruzada tabular de grande porte (10,84 $\mathrm{m}$ de espessura) (Fig.IV-3);

b) diamictito de até $45 \mathrm{~cm}$ de espessura, maciço, arenoso, vermelho/amarelo/ esbranquiçado, com clastos $\mathrm{mm}-\mathrm{cm}$; 


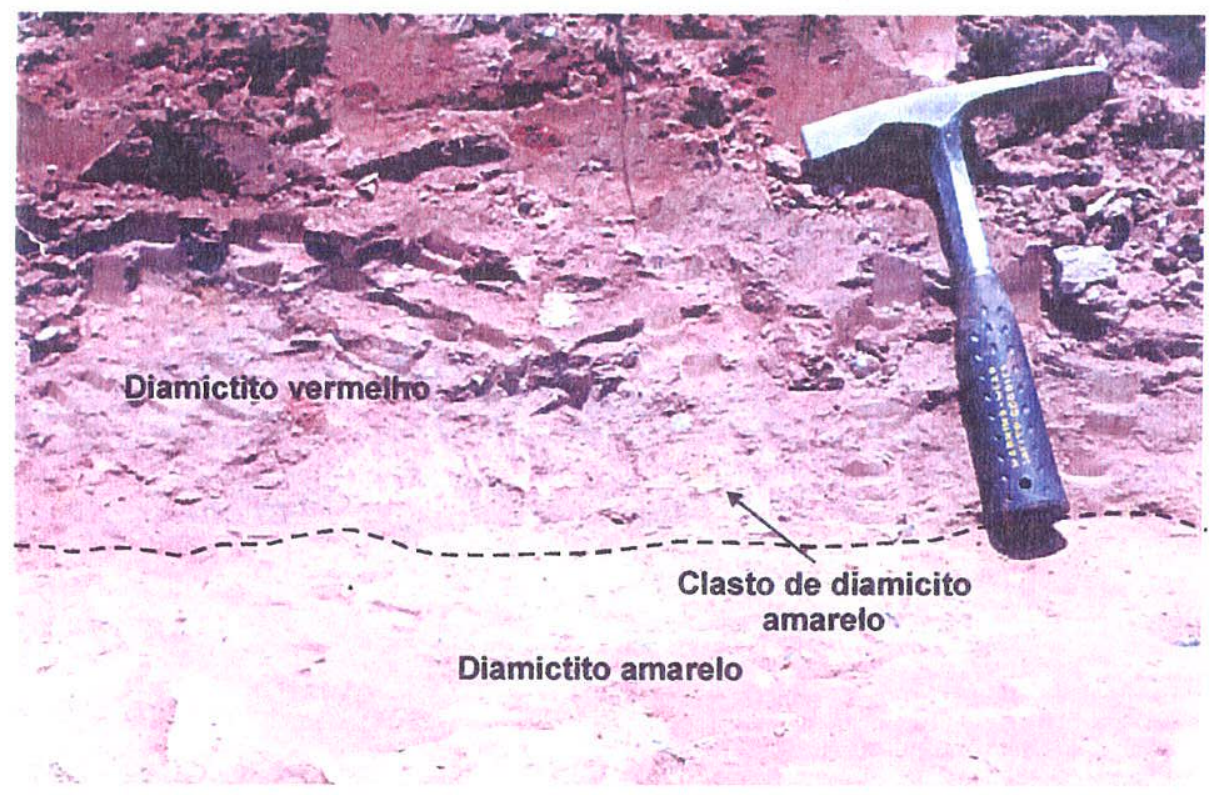

Figura IV-1: Contato entre diamictito vermelho de matriz síltica e diamictito amarelo, de matriz arenosa, ambos finamente estratificado (estratificação não visivel na foto em razão do intemperismo). Intercalações arenosas centimétricas no diamictito inferior parecem deformadas por cisalhamento. Diamictito subglacial de alojamento (tilito de alojamento) sobre diamictito subglacial de deformação (tilito de deformação). Notar clasto amarelo (seta) arrancado do diamictito inferior (amarelo) imerso no diamictito vermelho. Diamictitos situam-se sobre pavimento estriado de Witmarsum (Anexo 1).

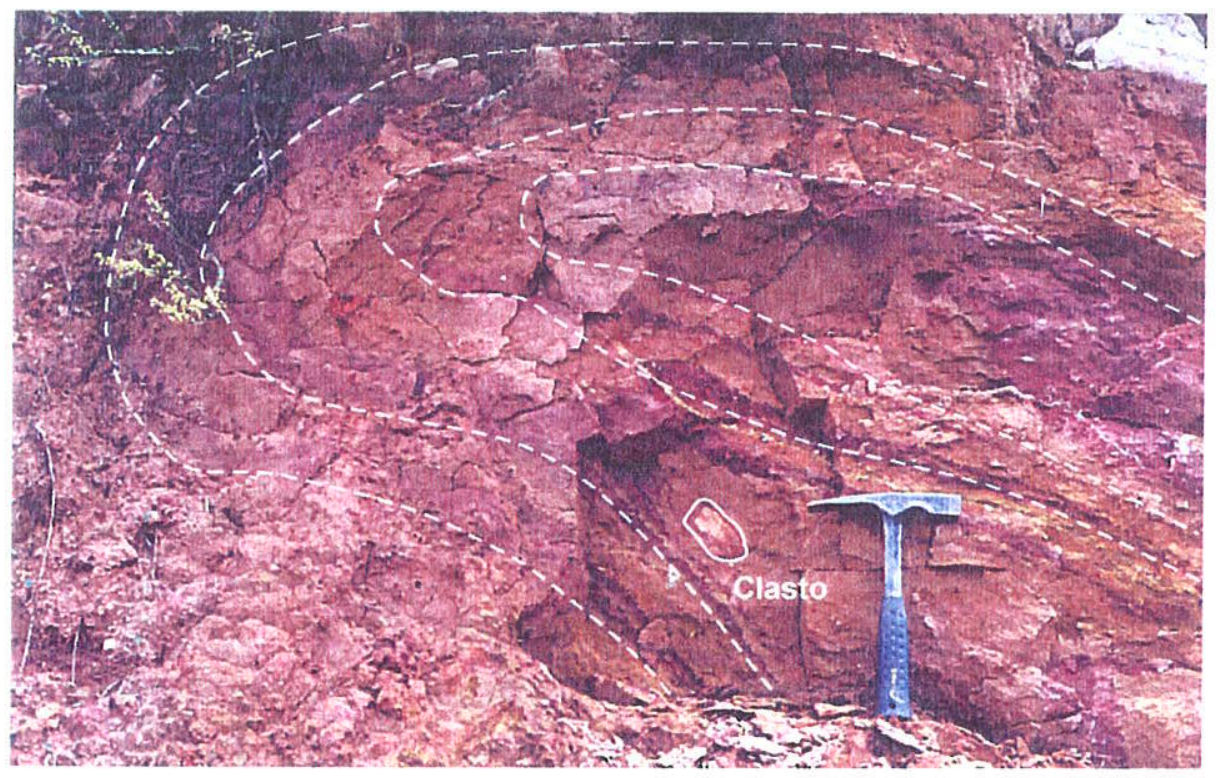

Figura IV-2: Diamictito silto-arenoso, amarelo e com bandas avermelhadas, estratificado e dobrado. Notar clasto com eixo maior paralelo ao flanco da dobra. Esta e outras dobras menores deitadas, destacadas na matriz, correspondem a narizes de dobras de fluxo, denotando deposição por fluxo de detritos. Poderia corresponder a diamictito supraglacial. Afloramento da Fazenda Schroeder (Anexo 1). 
c) arenito fino-médio, ocre a amarelado, feldspático, com raros clastos milimétricos dispersos e estratificação cruzada acanalada e tangencial na base $(2,46$ $m$ de espessura);

d) arenito médio, cor ocre e com lentes métricas de arenito grosso a até conglomeráticas intercaladas, estratificação plano-paralela e/ou cruzada longa e de baixo ângulo (6,48 $\mathrm{m}$ de espessura).

Geometricamente, esses corpos formam extensos bancos que sustentam platôs de significativa extensão na área. Por essas características podem ser utilizados como camadas-guia.

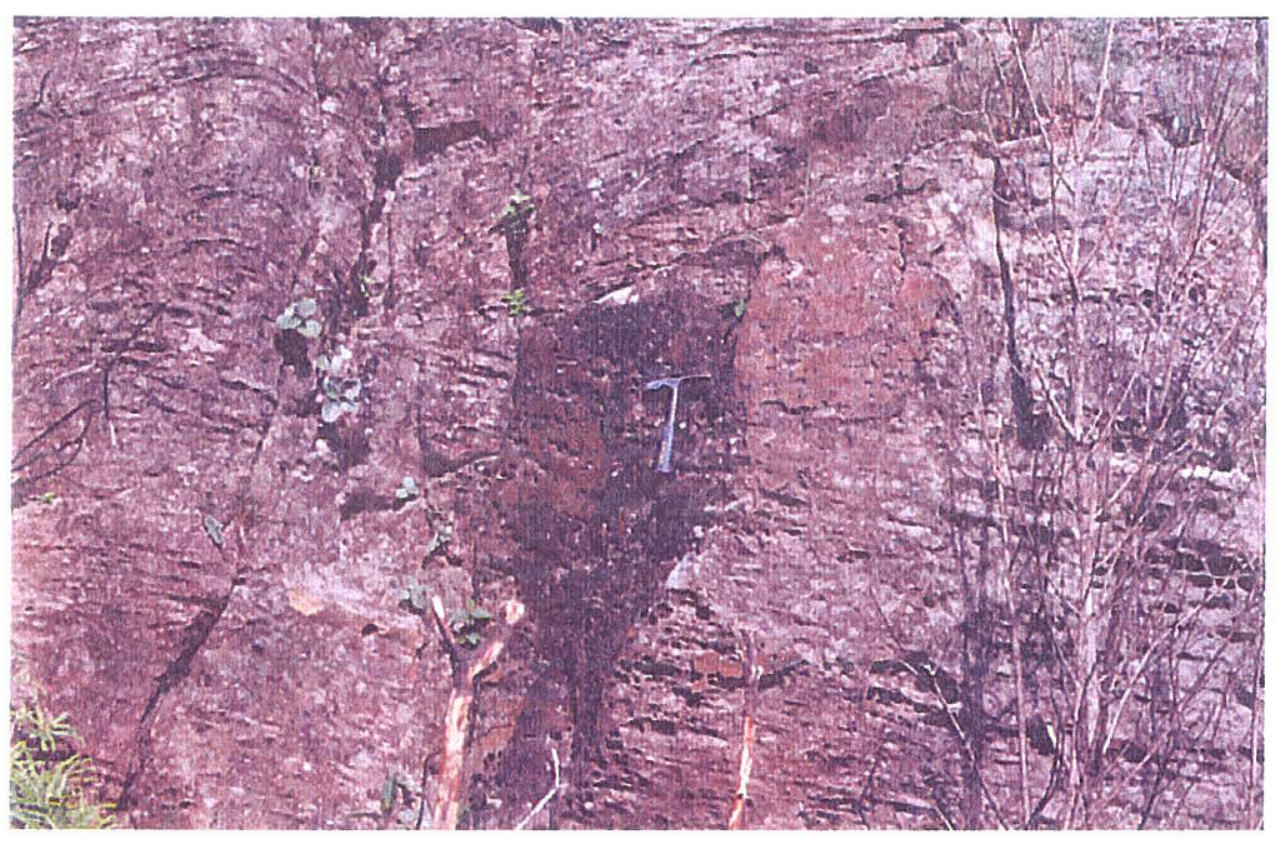

Figura IV-3: Arenito grosso apresentando estratificação cruzada tabular de grande porte, aflorando na encosta do morro Siebert. Banco de arenito B, Fig. IV-5.

- Unidade 4

Consiste de grande variedade de litofacies, predominando arenitos finos a conglomeráticos e diamictitos e, subsidiariamente, siltitos.

Diamictitos têm matriz siltosa a arenosa, estratificados ou maciços, com clastos dispersos variando de $\mathrm{mm}$ a $\mathrm{cm}$, e cores variadas (vermelho, ocre e amarelo). Os arenitos variam de finos a médios, feldspáticos, normalmente com estratificação cruzada acanalada de pequeno porte e tangencial na base, podendo em alguns pontos apresentar granodecrescência ascendente e deformações (Fig. IV-4). Os 
siltitos apresentam laminação fina, plano-paralela, cor ocre e podem estar cortadas por estruturas de corte e preenchimento.

Geometricamente esses corpos caracterizam-se por serem descontínuos, muitas vezes lenticulares, podendo apresentar contatos gradacionais, bruscos e até falhados (tectônica de colapso).

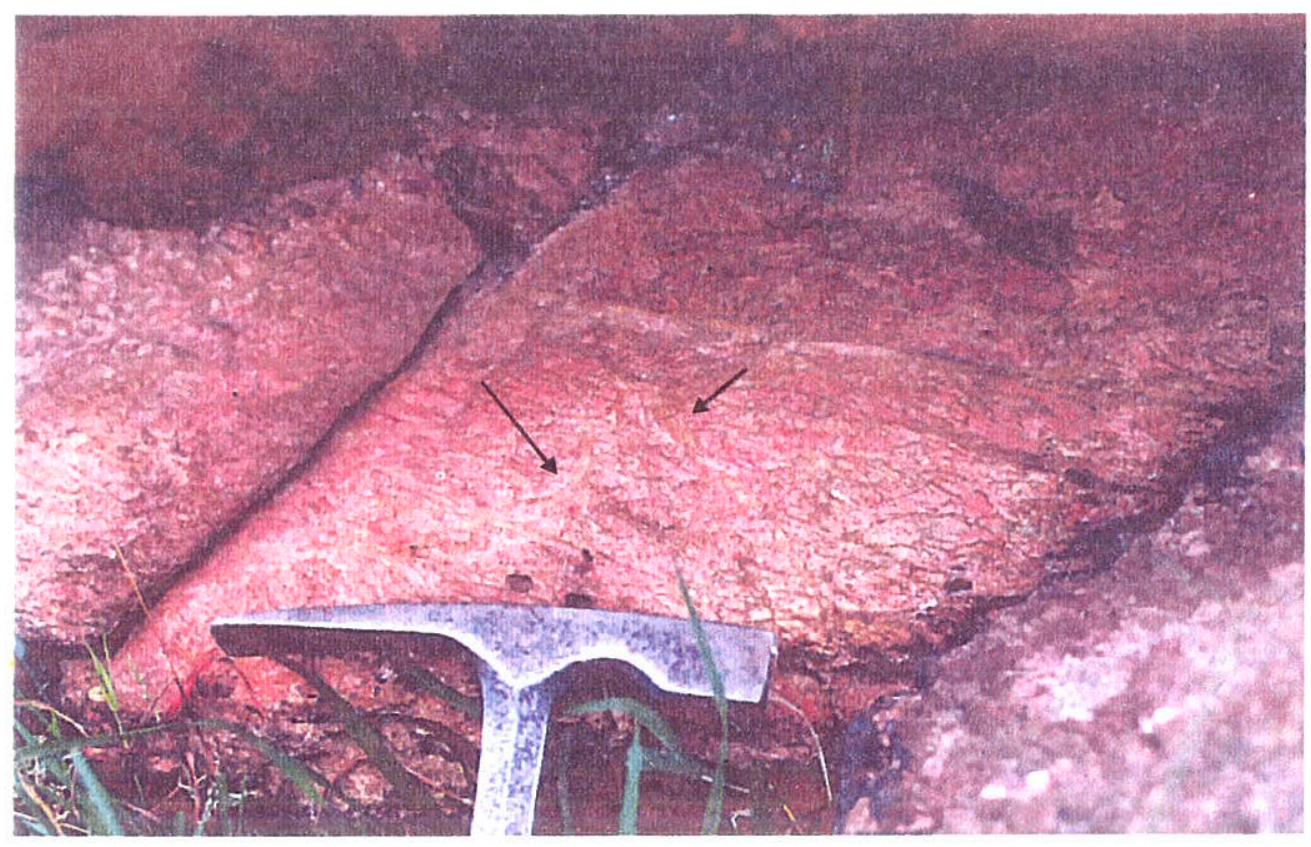

Figura IV-4: Arenito fino exibindo laminação cruzada acanalada de pequeno porte, pouco visível na foto. Notar pequenas deformações na laminação (setas), que podem ter sido causadas por escape de água ou por congelamento (crioestruturas ou criotexturas). Unidade 4, Anexo 1.

- Unidade 5

É formada basicamente por três litofacies distintas:

a) diamictito amarelo, arenoso, clastos milimétricos a centimétricos, aparentemente maciço;

b) siltito branco, com aureolas de liesegang, maciço e silicificado;

c) arenito conglomerático, branco, com clastos milimétricos, subangulosos e, aparentemente, maciço.

Geometricamente, essas litofacies podem apresentar formas lenticulares e tabulares, de contatos normalmente bruscos. O siltito maciço, em microscopia eletrônica de varredura (SEM-EDS), apresenta textura bastante homogênea, com grãos de geometria equiaédrica e alongada (Figs. IV-5 e IV-6). Embora corresponda a um tipo de depósito subaqüático, sua origem precisa é ainda obscura. 

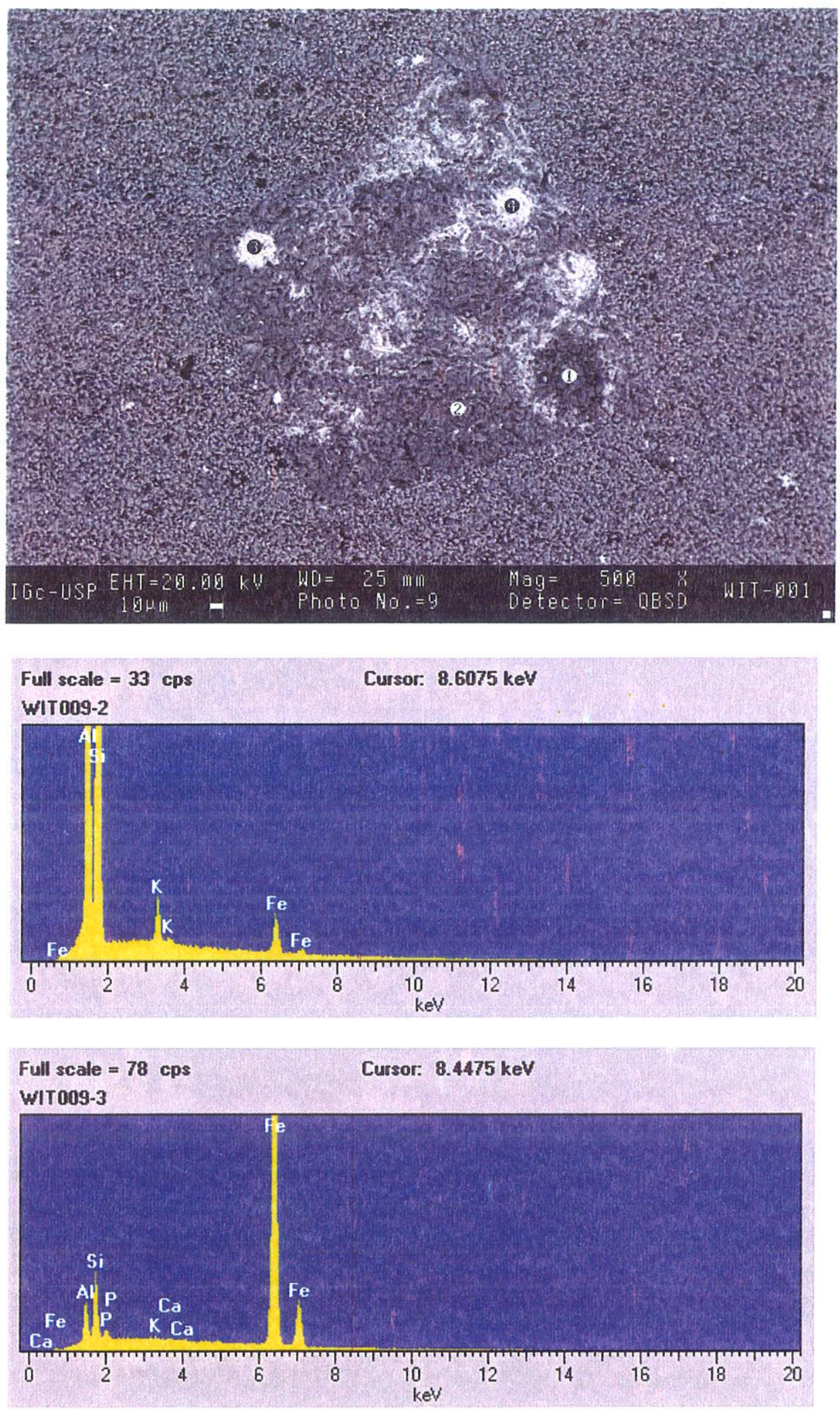

Figura IV-5: Imagem feita em microscopia eletrônica de varredura (SEM) e gráficos de EDS do siltito maciço. Números na imagem representam os pontos analisados por EDS. Notar textura homogênea da rocha e grão de geometria equiaédrica, cuja composição apresenta, principalmente, Al e Si. Em alguns pontos (WIT 009-3) há fósforo. 

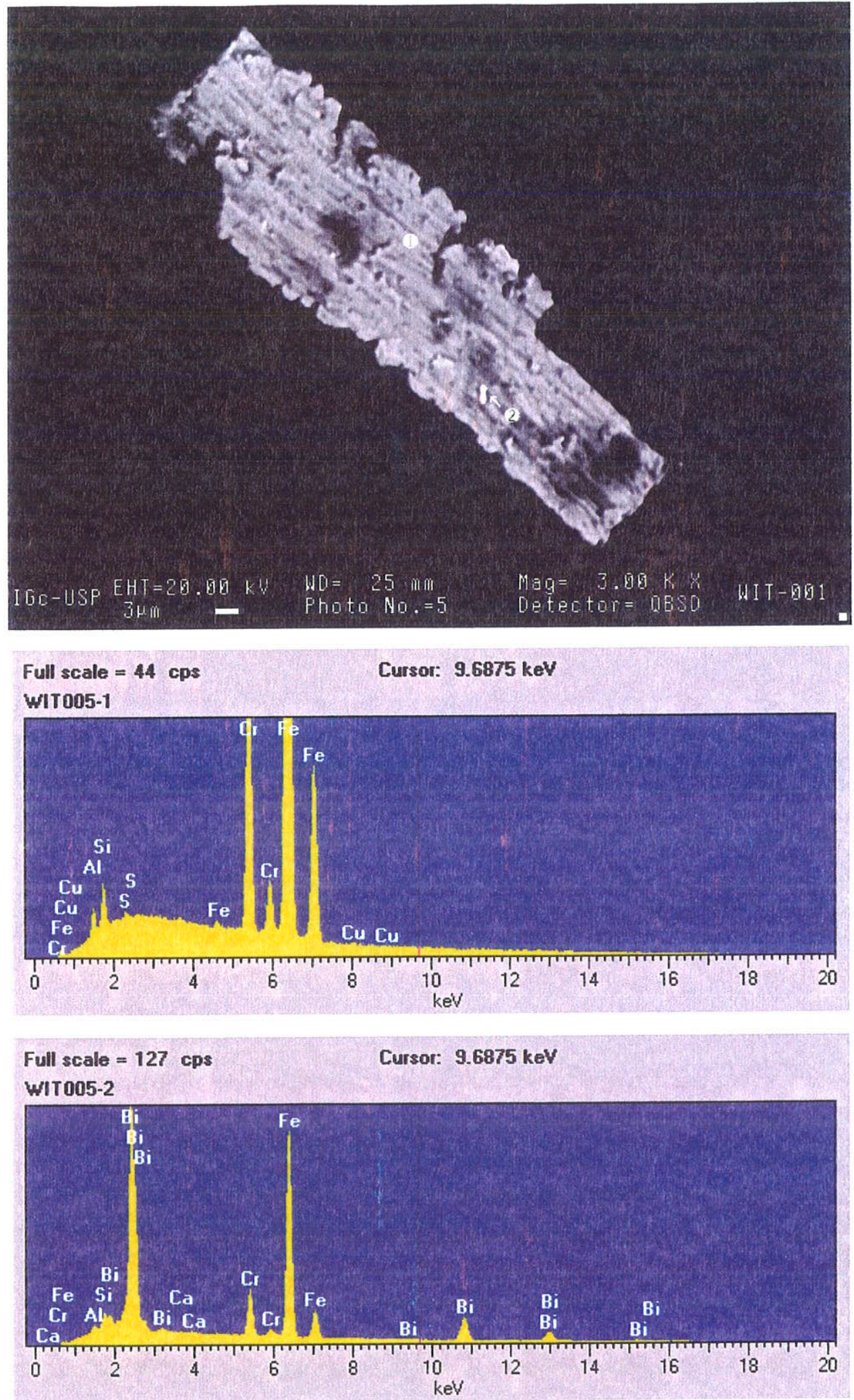

Figura IV-6: Imagem feita em SEM de siltito maciço e gráficos de EDS. Notar geometria alongada do grão. A presença, principalmente, de $\mathrm{Cu}$, indicada tratar-se, provavelmente, de um grão de cromita. 


\section{IV.2 - Estratigrafia}

Um dos aspectos mais controvertidos da geologia do Subgrupo Itararé é a sua estratigrafia (Bigarella et al., 1967; Rocha-Campos, 1967; Daemon e Quadros, 1970; Saad, 1977; Schneider et al., 1974; Santos, 1987; Petri e Souza, 1993 entre outros). A rápida variação lateral de facies, uma das caracteristicas mais marcantes dos depósitos glaciais, tem sido apontada como a principal dificuldade e limitação no estabelecimento de uma litoestratigrafia de consenso entre os pesquisadores.

O mapeamento geológico realizado (Anexo 1) demonstrou que várias unidades ou pacotes rochosos do Subgrupo Itararé na área empilham-se de modo ordenado, têm distribuição superficial relativamente ampla e mantém características litológicas e geomórficas distintas. Esta situação, obviamente, facilita a elaboração de uma estratigrafia local. Além do mapa geológico, outras técnicas utilizadas para a interpretação da estratigrafia incluíram o levantamento de seções (Anexo 2) e de perfil geológico (Fig. IV-7).

Um aspecto extremamente interessante derivado deste trabalho consistiu na organização de um quadro de distribuição estratigráfica e superficial dos diamictitos (Anexo 3). As diferentes camadas de diamictito reconhecidos na área mapeada são, pela primeira vez, colocadas dentro de um arcabouço estratigráfico, que permite estabelecer correlaçỏes, visualizar a distribuição superficial dos corpos, feições glaciais e as relações de contato. Essas informações são essenciais para interpretar a origem dessas litologias no quadro do sistema deposicional glacial, e reconstruir a história geológica glacial do flanco sul do arco de Ponta Grossa. O aprimoramento dessa informação levou a elaboração de uma "estratigrafia glacial" (em analogia à "glacial stratigraphy" do Pleistoceno), associada à ação do lobo glacial Paraná.

$\mathrm{Na}$ presente seção, a estratigrafia geral da área será brevemente descrita, seguida de comentários sobre a provável origem das litologias. A estratigrafia dos diamictitos será tratada em seção específica, dada a importância de que o tema se reveste.

\section{IV.2.1 - Perfil Colônia Witmarsum - BR-277}

\section{Descrição}

O perfil levantado mostrou-se composto, basicamente, de diamictitos e arenitos de diversos tipos e, subsidiariamente, de siltitos e arenitos conglomeráticos. Nos 6 quilômetros analisados, a espessura do Subgrupo Itararé medida é de cerca de 114 metros (Anexo 2).

O pacote 1 é formado por diamictito arenoso, cor amarela a ocre, clastos centimétricos a decimétricos, apresentando-se intensamente fraturado, dobrado e com 
pequenas falhas reversas de geometria listrica. Esse corpo é capeado por um pacote de arenito fino (pacote II), feldspático, com estratificação cruzada acanalada de pequeno porte e, semelhantemente ao pacote $\mathbf{I}$, intensamente fraturado.

O corpo III é formado por diamictito cinza, silto-argiloso, clastos milimétricos a centimétricos, intensamente dobrado e com lentes de arenito fino cisalhadas e estiradas. Sobre este pacote aflora arenito médio (pacote IV), avermelhado, feldspático, estratificação cruzada tabular e com dobras de pequeno porte (decimétricas).

Os pacotes V e VI são constituídos, respectivamente, por arenito médio-fino, razoavelmente bem selecionado e apresentando estratificação cruzada acanalada, e diamictito de matriz areno-siltosa e cor avermelhada. No topo do pacote VI há estruturas em forma de cunha, que são preenchidas por arenito fino-médio $e$ feldspático (cunhas de areia ou sand wedges), que correspondem aos sedimentos do pacote VII e diamictito silto-arenoso (cunhas compostas ou composite wedges).

Os pacotes VIII e IX são compostos por dois diamictitos distintos, os quais podem ser observados no ponto 3 . O diamictito inferior (VIII) apresenta matriz siltoarenosa, vermelha, clastos milimétricos a centimétricos e estratificação descontínua. $O$ contato com o diamictito sobrejacente (IX) é brusco, irregular e erosivo. O pacote IX possui cor amarelada a ocre, matriz semelhante ao diamictito subjacente, mas, aparentemente, com uma quantidade menor de clastos. Nota-se a inserção de fragmentos do diamictito vermelho, inferior, no sobrejacente, principalmente na zona de contato.

$\mathrm{O}$ pacote $\mathbf{X}$ é formado por arenito fino-médio, ocre a vermelho claro, feldspático e com estratificação cruzada acanalada e forma, da mesma maneira que os pacotes $\mathrm{V}$ e $\mathrm{VI}$, um extenso platô. No pacote $\mathrm{XI}$ ocorre uma fina camada ( $<1$ metro) de diamictito ocre a amarelo, silto-arenoso, com clastos milimétricos a centimétricos. Sobre este pacote (pacote XII) há uma camada de siltito branco, maciço, silicificado, com aureolas de liesegang, que está em contato brusco com arenito grosso, conglomerático e com clastos subangulosos.

\section{Interpretação}

Os primeiros quatro pacotes observados, ao contrário do restante da seção, apresentam-se deformados (Unidade 2, Anexo 1). Pelas características litológicas e estruturais observadas no pacote I, há indicações de que as deformações foram causadas pela ação direta do lobo glacial Paraná (glaciotectonismo). 
O estudo faciológico dos demais pacotes sugere uma grande variedade de ambientes deposicionais: a) pacote 11 , pequenos deltas em ambiente lacustre; $b$ ) pacote III, diamictito de fluxo; c) pacote IV: arenitos de plataforma marinha rasa.

Os pacotes V e VI formam um platô relativamente extenso na área, onde predominam processos deposicionais ligados à planície de lavagem glacial (outwash ou sandur), que pode ser utilizado como camada-guia na região. Semelhantemente ao pacote I, que possui matriz arenosa e está próximo ao arenito Furnas, o conjunto VI teve contribuição de sedimentos erodidos do arenito subjacente (pacote $\mathrm{V}$ ), sendo mais um exemplo do retrabalhamento característico do ambiente glacial. No topo do pacote VI há indicações do desenvolvimento de clima periglacial (cunhas de areia). Essas estruturas serão descritas e interpretadas adiante (Cap. IV.4., Feições Periglaciais).

Os pacotes VIII e IX ilustram de maneira apropriada a superposição de diamictitos por avanços sucessivos da frente glacial. A incorporação de fragmentos do pacote VIII no diamictito sobrejacente, sugere fortemente o caráter erosivo e ativo de sua deposição, caracterizando, portanto, um ambiente subglacial de formação.

O pacote $\mathbf{X}$ forma, semelhantemente aos pacotes $\mathrm{V}$ e $\mathrm{VI}$, platôs ou zonas de relevo de declive baixo. Esses platôs extensos e sobrepostos, sugerem, a primeira vista, diversas superfícies glaciais exumadas, inclusive com algumas feições morfológicas preservadas. Com exceção das superfícies estriadas, a preservação e exposição de superfícies glaciadas exumadas são extremamente raras no registro préPleistoceno. O estudo desses platôs tem revelado a grande variedade e riqueza de facies e estruturas glaciais e periglaciais preservadas na seqüência sedimentar levantada, variedade que pode ser comparada com os depósitos pleistocênicos e atuais.

Os pacotes XI e XII, pelas características apresentadas, sugerem um ambiente glácio-lacustre de deposição. O corpo de arenito conglomerático estaria associado a fluxo de detritos, dentro do mesmo contexto.

\section{IV.2.2 - Seção Morro Siebert}

\section{Descrição}

A seção localiza-se próxima a Gästehaus (Pousada) Siebert (Anexo 1), onde pode-se observar uma sucessão de diamictitos e arenitos, perfazendo um total de 43,26 m de espessura (Fig.IV-7). Dois intervalos litológicos podem ser reconhecidos. 


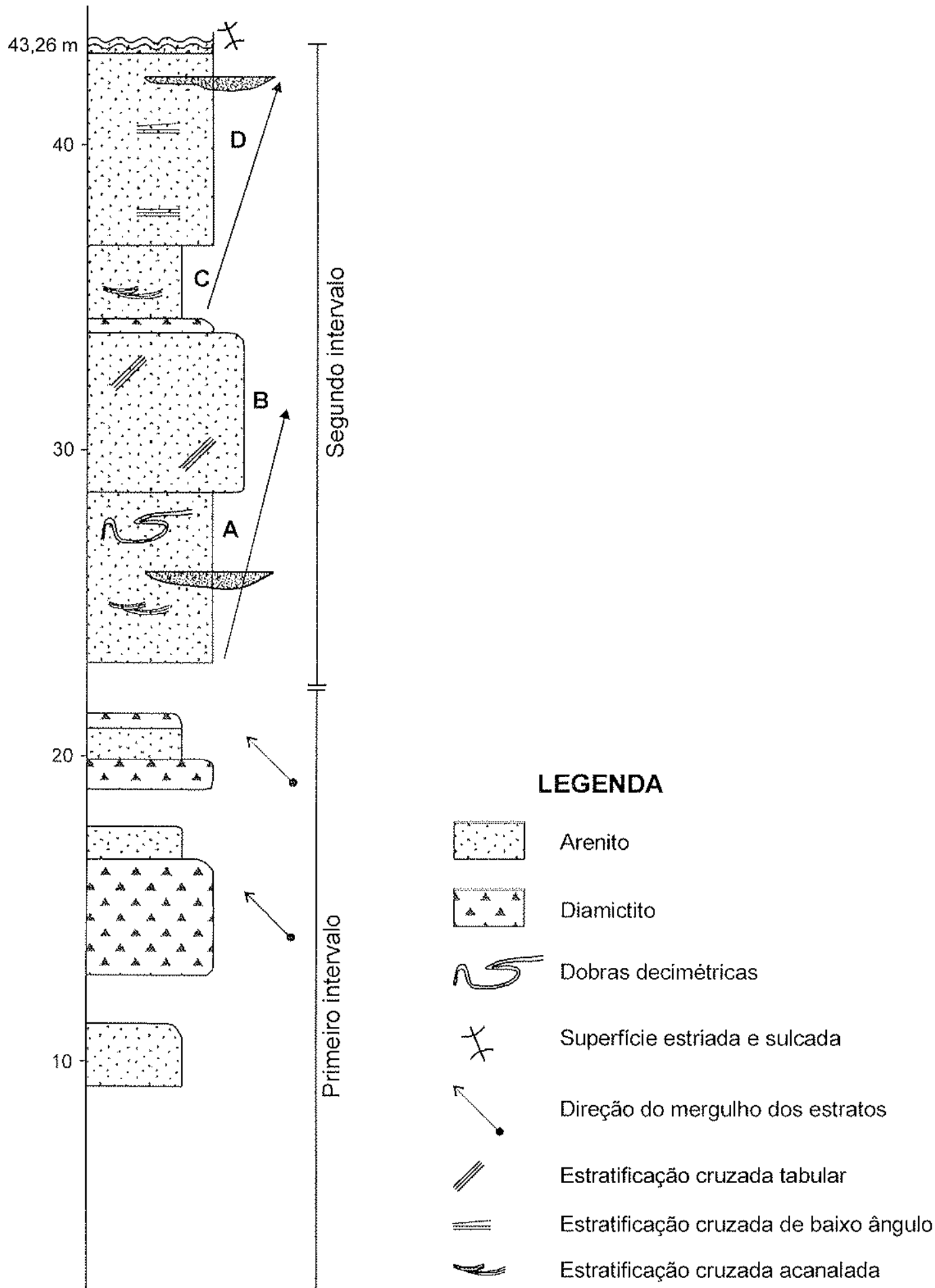

A, B, C e D Bancos de arenito

Figura IV-7: Seção levantada no morro atrás da Pousada Siebert em Witmarsum, PR. 
O intervalo inferior apresenta exposições descontínuas de camadas decimétricas a métricas de diamictitos arenosos, ocre a amarelados, clastos milimétricos a centimétricos, grosseiramente estratificados e camadas menos espessas de arenito fino, ocre, feldspático e laminado. O pacote encontra-se adernado, onde a estratificação acompanha o declive do morro Siebert para NW.

O segundo intervalo da seção consiste quase que exclusivamente de arenitos. Quatro bancos distintos são visíveis. O primeiro, com 10,84 m de espessura, consiste de arenito médio-grosso, cor branca a amarelada, estratificação cruzada acanalada e tangencial, lentes conglomeráticas e dobras de pequeno porte (banco $\mathrm{A}$ ).

O banco B é formado por arenito grosso, amarelo-esbranquiçado, feldspático, de estratificação cruzada tabular (Fig. IV-8).

Separando o primeiro do segundo banco arenoso ocorre uma camada ou lente de diamictito arenoso, avermelhado a amarelo esbranquiçado, de aspecto maciço e contendo clastos milimétricos a centimétricos. Os seus contatos, inferior e superior, são bruscos. O banco $\mathrm{C}$ é formado por arenito fino-médio, ocre-amarelado, feldspático, com poucos clastos milimétricos dispersos e estratificação cruzada tangencial e acanalada de médio porte.

O último pacote desta seção é constituído por arenito médio, ocre, estratificação plano-paralela e cruzada de baixo ângulo (Fig. IV-9), além de lentes conglomeráticas intercaladas.

\section{Interpretação}

A estratificação observada no diamictito arenoso apresenta caimento geral para NW, seguindo grosseiramente o declive do morro Siebert. Uma interpretação segura quanto ao ambiente deposicional do diamictito arenoso não é ainda possivel. Contudo, as indicações de um sistema glacial-terrestre para a área como um todo, sugerem uma gênese associada ao mesmo contexto. Posteriormente, com o recuo da geleira, formaram-se lagos e pequenos deltas associados, representados pelo arenito fino e laminado, feição esta que é relativamente comum em planícies de lavagem glacial.

Outro ponto a ser discutido é o adernamento dos estratos para NW, algumas hipóteses quanto a origem dessa deformação podem ser levantadas, a) flanco de grandes dobramentos produzidos pela movimentação da geleira neopaleozóica; b) escorregamento (fluxo de detritos); e c) falhamentos pós-Itararé que adernaram o pacote. 


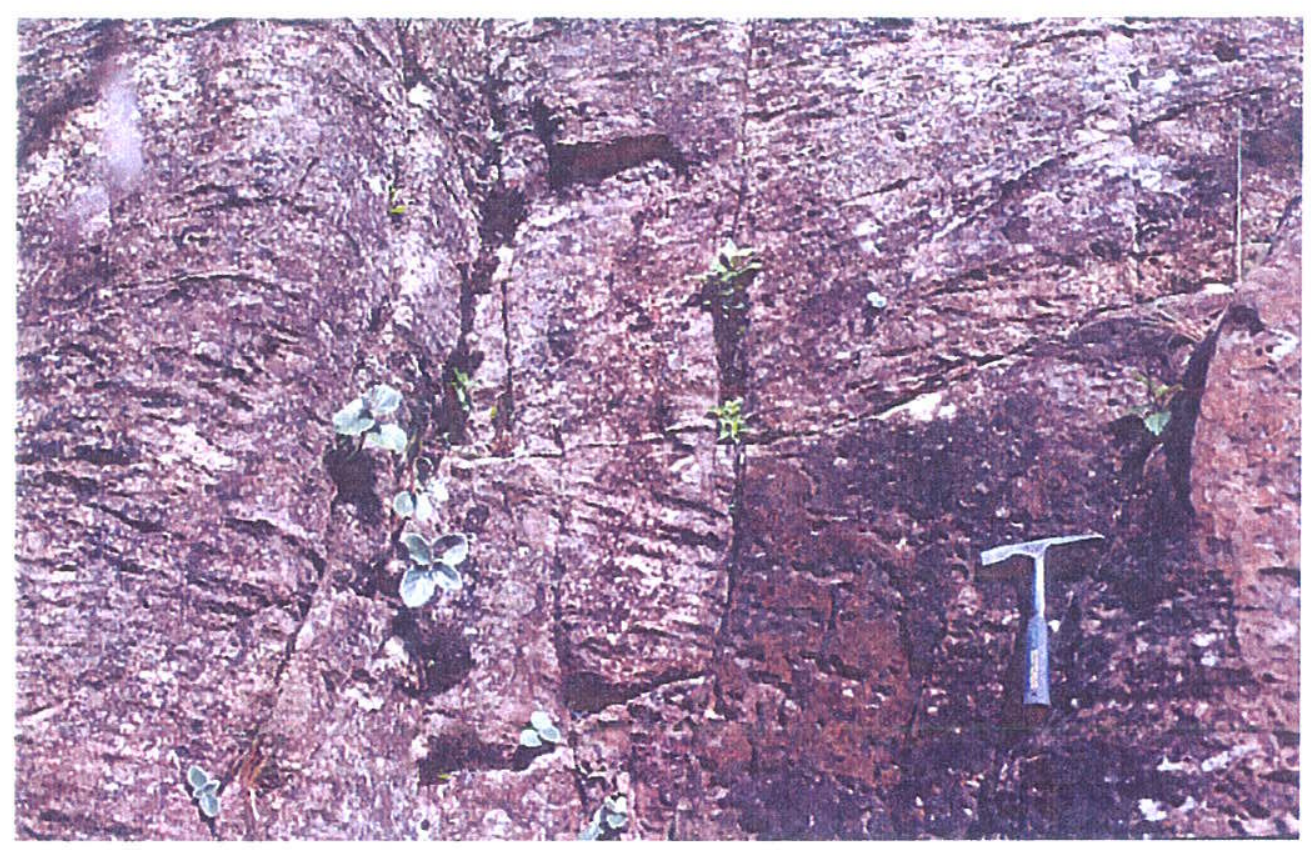

Figura IV-8: Estratificação cruzada tabular, cortada por canal a $130^{\circ}$. Seção do Morro Siebert. Banco de arenito B. Foto de maior detalhe da Figura IV-3.

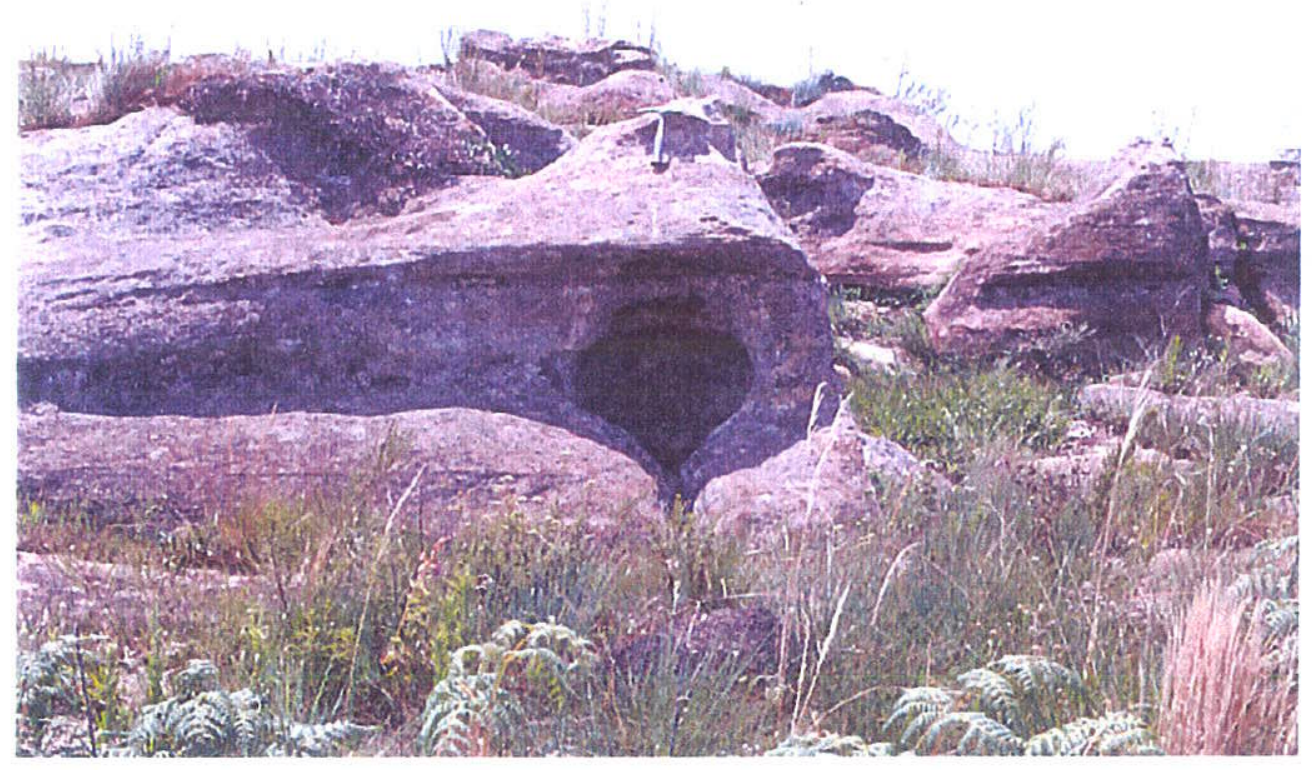

Figura IV-9: Arenito médio com lentes conglomeráticas e estratificação plano-paralela e cruzada de baixo ângulo, interpretadas como de plataforma marinha rasa. Seção do Morro Sibert. Banco de arenito D. 
O segundo intervalo da seção, ao contrário do primeiro, não apresenta deformações, com exceção do primeiro banco de arenito, que mostra pequenas dobras (de até $30 \mathrm{~cm}$ ). Há indicações de avanço gradual do nivel do mar, com algumas oscilações, chegando a um ambiente de plataforma marinha rasa. $\mathrm{O}$ banco $\mathrm{A}$ descrito mostra um sistema fluvial, provavelmente, entrelaçado, representado pelo arenito médio-grosso com lentes conglomeráticas intercaladas, que estariam associadas a barras de canal. O banco $B$, associado a uma zona de intermaré (foreshore), sugere influência marinha mais pronunciada, mas ainda com influência fluvial, caracterizada por cortes de canais com paleodrenagem que dista $130^{\circ} \mathrm{em}$ relação a estratificação.

As lentes de diamictito arenoso poderiam estar associadas à oscilação da margem da geleira ou a outro avanço glacial na área. Com o recuo da geleira, ter-se-ia instalado um sistema de canais distributários associados a ambiente deltaico, que é representado pelo arenito fino-médio com estratificação cruzada acanalada (banco $\mathrm{C}$ ). O último banco de arenitos (D) sugere ambiente de plataforma marinha rasa.

No topo desses arenitos nota-se uma ampla superficie com estrias e sulcos glaciais (Fig. IV-10) alinhados segundo N23W. As estrias e sulcos são retilineos. Os sulcos são profundos e atingem 50 centímetros de largura. Feições indicativas de substrato inconsolidada durante a abrasão (abas de arenito escorregados nos sulcos) são comuns. Um segundo nível estriado foi observado, separado do primeiro por cerca de $30 \mathrm{~cm}$ de arenito. As características acima sugerem o avanço de geleira de maré aterrada em plataforma marinha rasa, de margem oscilante. Contudo, os depósitos normalmente relacionados ao recuo da geleira aterrada (depósitos proglaciais subaquáticos) não foram identificados. Sendo assim, duas hipóteses podem ser formuladas:

a) erosão e retrabalhamento dos sedimentos por correntes e/ou processos presentes na região proglacial terrestre e marinha; $e$

b) erosão posterior (atual) dos afloramentos e/ou cobertura vegetal, dificultando sua identificação. 


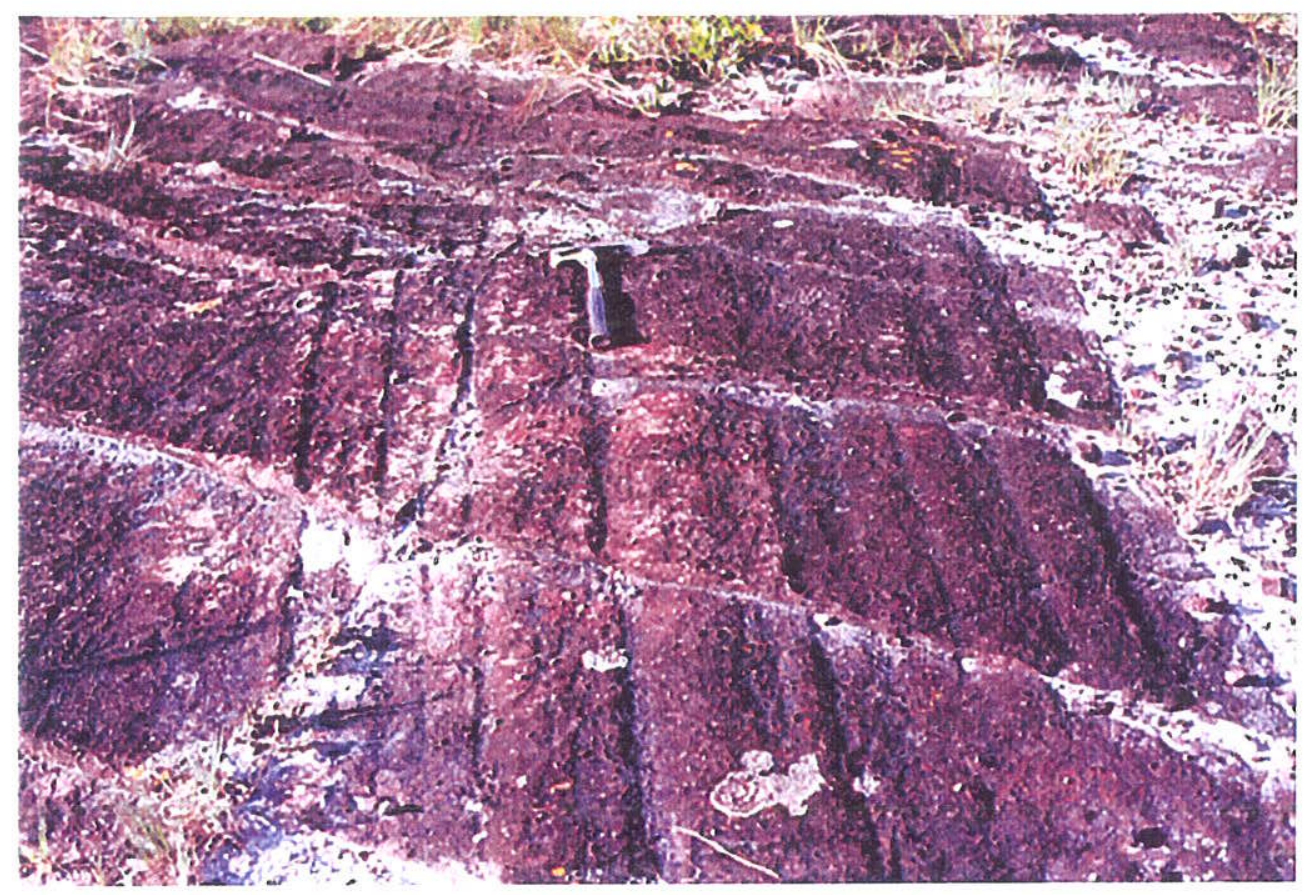

Figura IV-10: Pavimento estriado e sulcado inferior, truncando arenito do topo da seção levantada (Banco D). Notar estrias e sulcos retilíneos e alinhados, orientados segundo N23W. As características do arenito sugerem formação da superfície pela ação de geleira de maré aterrada em plataforma marinha rasa, de margem oscilante.

\section{IV.2.3 - Estratigrafia glacial}

Estratigrafia glacial diz respeito ao estabelecimento da ordem relativa das formas de terreno, depósitos glaciais e à interpretação desses elementos em termos dos ambientes glaciais (Bennett e Glasser, 1996). O conceito foi desenvolvido para sucessões glaciais terrestres e sua extensão ao ambiente glácio-marinho é controvertido.

A superposição e diversidade de diamictitos e rochas associadas de origem glacial observadas na área estudada, e a provável natureza terrestre da maioria desses depósitos torna possivel a tentativa de aplicação do conceito de estratigrafia glacial da sucessão sedimentar examinada.

O modelo inicial de estratigrafia glacial da área foi proposto por Bigarella et al. (1967) e Fuck e Bigarella (1967), e será discutido em detalhe no Capítulo VI. Neste capítulo trataremos apenas da estratigrafia glacial levantada em Witmarsum.

\section{Sucessão de diamictitos}

O esquema estratigráfico de diamictitos baseou-se em quatro características principais: a) posição estratigráfica; b) feições sedimentológicas; c) natureza do contato; e d) cor. 
O controle estratigráfico utilizado na elaboração do Anexo 3 é qualitativamente variável e levou em conta não só o empilhamento verificado nas seções medidas (seções 5-8), quanto a posição topográfica entre as seções (seções 1-4), o uso de camadas-guia locais (seções 5-8) e características sedimentológicas das litologias, inclusive cor. Critérios similares foram usados na correlação entre a sucessão estabelecida na área da Colônia Witmarsum e outras seções medidas (seções 4, Palmeira e São Luis do Purunã).

Feições sedimentares das litologias presentes estão descritas em tópicos anteriores e incluem estruturas sedimentares dos diamictitos e arenitos. O mesmo se dá com os tipos de contato observados entre diamictitos, entre estes e os arenitos e a associação com feições glaciais (pavimentos e superfícies estriados, estruturas glaciotectônicas).

Um aspecto que chama a atenção na sucessão estudada é a variação na cor dos diamictitos. Embora não se possa excluir a influência do intemperismo, a observação sistemática de afloramentos indicou a possibilidade de uma certa consistência na distribuição estratigráfica dessa caracteristica. Isto é demonstrado, por exemplo, pela presença de clastos sedimentares erodidos (floats) de diamictito inferior dentro de diamictito superposto e de persistência de cores distintas em diamictitos de contato brusco, interpenetrativo. Note-se que em vários casos, a percolação de água ao longo de fraturas em diamictitos, durante o intemperismo, e a formação de anéis de liesegang produzem um padrão caótico de distribuição das cores originais, obscurecendo o seu reconhecimento.

\section{Seqüências de tills (tilitos) múltiplos}

Seqüências de tills múltiplos são reconhecidas nos depósitos glaciais pleistocênicos e recentes. Tradicionalmente, essas seqüências são interpretadas como o produto de sucessivos episódios glaciais. Contudo, muitas dessas seqüências têm sido atualmente interpretadas em termos de um único episódio glacial.

Segundo o modelo desenvolvido por Boulton (1977), em locais onde espessas seqüências de sedimentos supraglaciais cobrem superficies glaciadas, múltiplas camadas de till (till de alojamento, till de melt out e till de fluxo) podem estar superimpostas. Este tipo de seção é chamado de seqüência de till tripartite (tripartite till sequence). Durante o avanço da geleira há a deposição do till basal ou de alojamento e na sua retração ocorre a deposição de till de derretimento (till de melt out). Com a evolução do recuo glacial, os sedimentos de melt out são cobertos por tills de fluxo. Portanto, a correta interpretação de cada camada de till e das facies 
presentes é de vital importância para a melhor caracterização dos sucessivos avanços e recuos de uma geleira (Boulton, 1979; Bennett e Glasser, 1996).

Outro modelo de superposição de tills é descrito por Eyles et al. (1982) na costa nordeste da Inglaterra. Essas seqüências glaciais são compostas por unidades de till de alojamento separadas por camadas descontinuas de silte $e$ areia interpretadas em termos de múltiplos avanços do gelo, sendo as areias depositadas durante épocas livres de gelo. Eyles et al. (1982) propuseram um modelo alternativo de interpretação dessas seqüências, denominada de lobos glaciais concorrentes. Os autores argumentam que a seqüência pode ter sido depositada durante um único episódio de avanço glacial. As camadas de areia corresponderiam a depósitos de água de degelo subglacial, indicando a localização de condutos subglaciais. Esta interpretação é consistente com a forma descontinua das camadas de areia. A mudança na composição dos clastos de cada unidade de till de alojamento estaria relacionada à ação de lobos glaciais concorrentes, erodindo e transportando detritos de diferentes áreas fontes. O desvio lateral no fluxo desses lobos glaciais é responsável pela superposição das diferentes camadas de till de alojamento

\section{Estratigrafia glacial da área}

A correlação estratigráfica entre as sucessões de diamictitos das seções 1-4 e entre estas e as seções 5-8 (Anexo 3) é precária e em parte está controlada pela topografia. As dificuldades observadas na correlação desses pacotes estão associadas a uma grande zona de falha, cujo rejeito não pôde ser calculado. Contudo, no diagrama do Anexo 3, pode-se observar sete seqüências de 2-6 diamictitos distintos superpostos, normalmente de pequena espessura.

Nas seções 5-8 do Anexo 3 observa-se dois bancos de arenito contínuos que são utilizados como camadas-guia. Nesta porção, ocorrem seis corpos de diamictitos superpostos, podendo perfazer um total de 10-11 diamictitos estratigraficamente empithados na área da Colônia Witmarsum.

Outra característica de grande interesse (Anexo 3), visivel nas seções 1, 6 e 7 do quadro, são os contatos claramente erosivos observados entre camadas de diamictito. Esse aspecto sugere origem subglacial para os diamictitos superiores e ocorrência de pelo menos quatro avanços glaciais na área da Colônia Witmarsum, juntamente com as superficies e pavimentos estriados observados, pode-se elevar esse número ao mínimo de 6 avanços. 
Os dois modelos de empilhamento de seqüências de tilitos múltiplos, proposto por Bouton (1974) e Eyles et al. (1982), podem ocorrer nas seções levantadas na área. A aplicação dos modelos deposicionais acima descritos está condicionada à correta interpretação da gênese desses corpos de diamictito. Mesmo necessitando de estudos mais aprofundados, alguns corpos podem ser inicialmente atribuídos a tilitos de alojamento (vermelho 1, amarelo 5), de deformação (amarelo 1) e de fluxo (amarelo 2).

A análise granulométrica dos diversos corpos de diamictitos presentes na seção (Anexo 3), foram plotados em diagrama triangular (Fig. IV-11) e mostra que os diamictitos se distribuem, principalmente, entre as frações areia e silte. Pode-se separá-los em 3 grupos distintos.

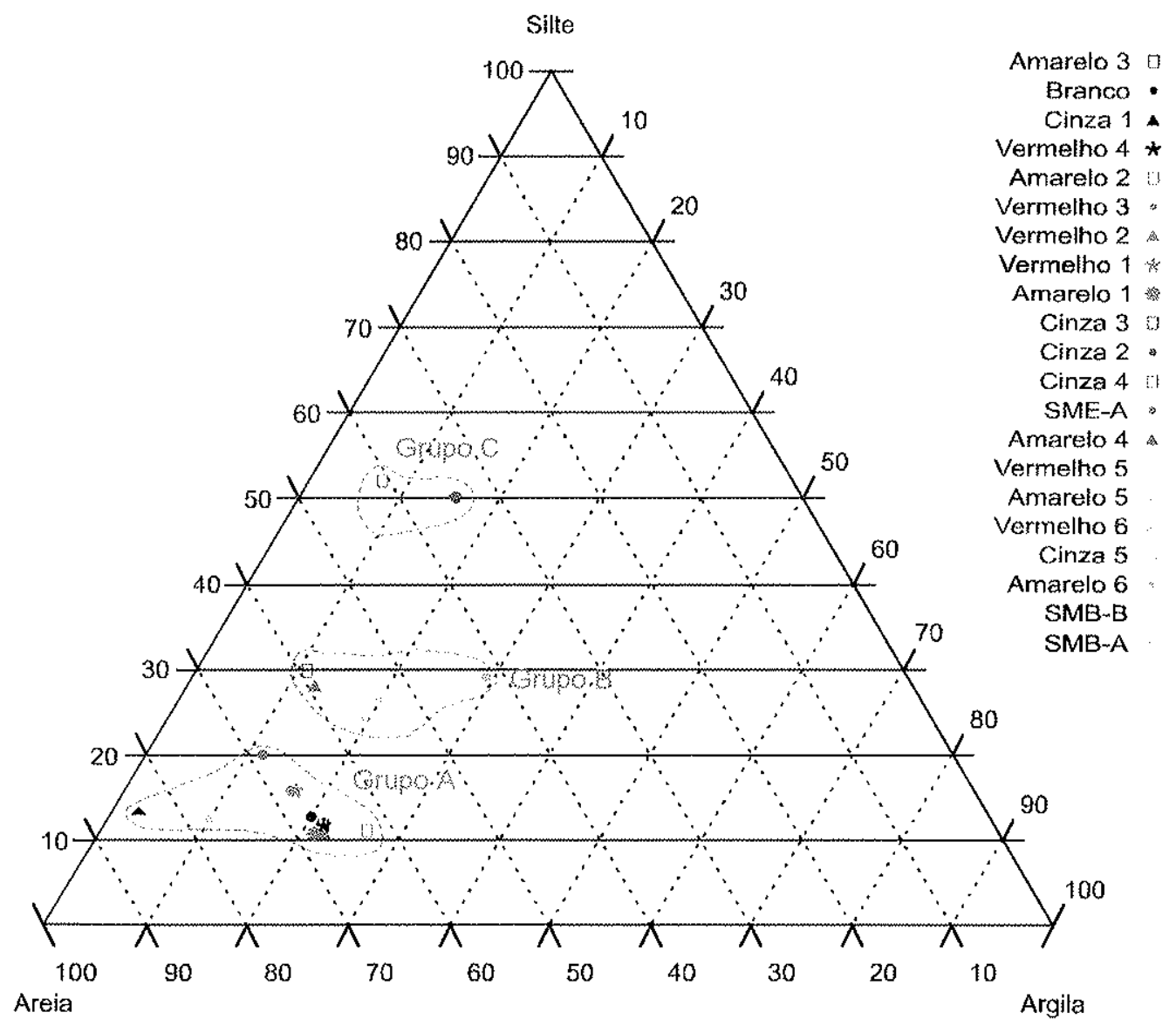

Figura IV-11: Diagrama triangular dos diamictitos analisados. Notar grupos granulometricamente distintos $(A, B$ e $C)$. $O$ Grupo $A$ representa os diamictitos basais da seção. Os grupos $B$ e $C$ pertencem a porção superior do pacote sedimentar. $O$ Grupo $C$ está relacionado a uma camada de diamictito cinza, silto-argiloso, abaixo do primeiro pacote de arenito (Anexo 2). As siglas correspondem aos diamictitos apresentados no Anexo 3. SME = Seção Morainas de Empurrão; SMB = Seção do Morro Siebert. 
- Grupo A: reúne os diamictitos que se assentam na base da seção, próximos, portanto, ao arenito Furnas. Outro ponto a ser destacado neste primeiro agrupamento, é a relação fino/grosso, cuja média gira em torno de 0,55 , sendo, portanto, constituídos, predominantemente, pela fração areia.

- Grupo B: apresenta-se mais deslocado em direção as frações mais finas (silte e argila) do diagrama triangular, o que acarreta no aumento da relação fino/grosso, podendo chegar a 1,49. Estratigraficamente se localizam na porção superior da seção.

- Grupo C: está bastante deslocado em relação aos demais, a relação das frações fina/grossa chega a atingir 2,03. Sua posição estratigráfica corresponde a uma camada de diamictito cinza, silto-argiloso, abaixo do primeiro banco de arenito. $O$ Grupo C está, portanto, inserido no pacote sedimentar associado ao Grupo B.

Como pôde ser observado, a partir dos dados acima apresentados, conclui-se que há uma expressiva contribuição de sedimentos erodidos pela geleira da Formação Furnas e que foram incorporados nos diamictitos basais da seção (Grupo A), acarretando no deslocamento dos pontos em direção a fração areia. Isto não é observado nos diamictitos superiores da seção (grupos B e C), que são compostos, preferencialmente, por frações mais finas (silte e argila), devido a não contribuição ou de menor monta de sedimentos erodidos da Formação Furnas.

\section{IV.3 - Estruturas associadas}

\section{IV.3.1 - Estruturas de colapso}

Afloramento relativamente extenso, inserido na unidade 4 (Anexo 1), exibe conjunto de litologias incluindo diamictito vermelho, silto-argiloso e deformado (Fig. IV12); arenito fino médio com granodescrecência ascendente, micro-laminação cruzada de marcas onduladas migrantes (Fig. IV-13); arenito conglomerático, mal selecionado, estratificado e acanalado e siltito laminado com pequenos clastos caídos e estruturas de corte e preenchimento. Contatos entre as duas últimas litologias são verticais e marcadas por falhas reversas de alto ângulo (Fig. IV-14). Em seu conjunto a associação sugere ambiente deposicional flúvio-glacial e lacustre afetado por tectônica de colapso por derretimento de gelo.

McDonald e Shilts (1975) descrevem três tipos de falhas que ocorrem em sedimentos depositados sobre, dentre ou próximos a geleiras:

a) falhas normais ou de gravidade: com ângulos maiores que $45^{\circ}$ e forma de capa côncava, formadas por eventos de extensão, podendo ocorrer durante um dobramento ou escorregamento; 


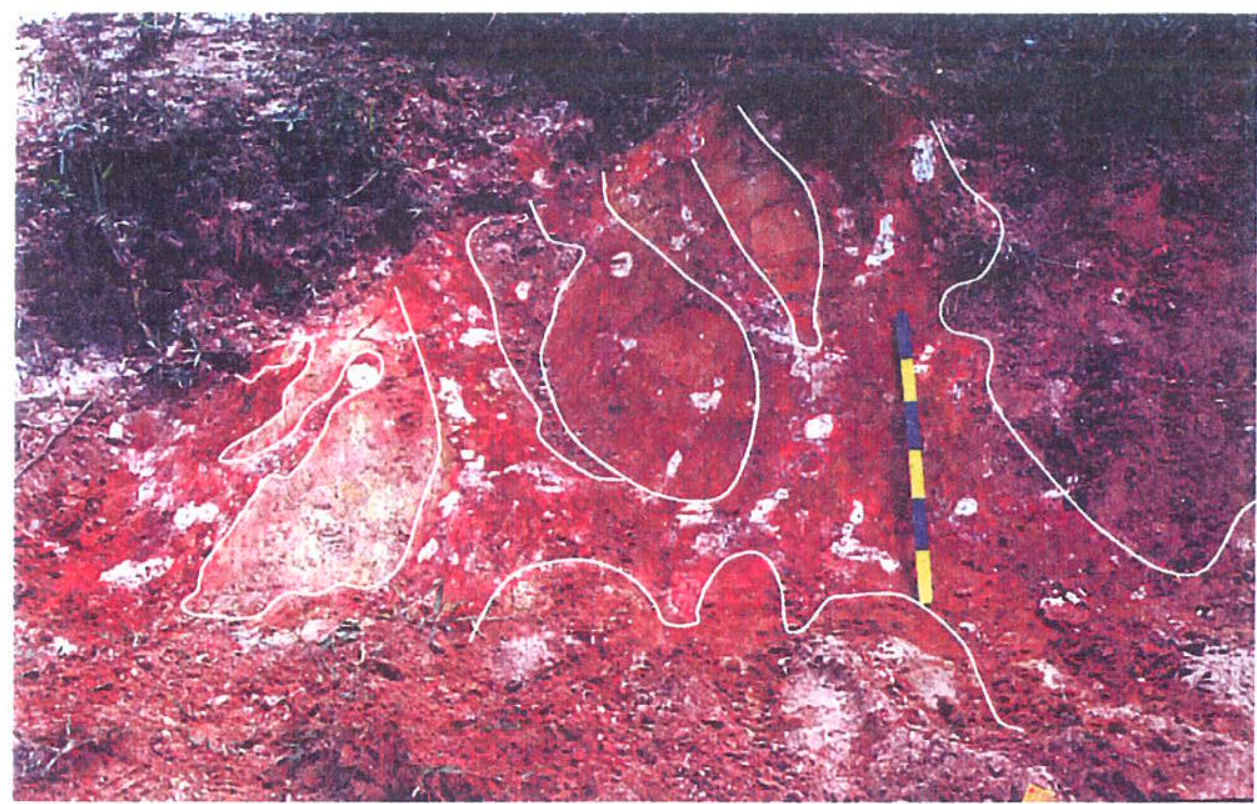

Figura IV-12: Diamictito silto-argiloso e deformado. Associado a depósitos de moraina frontal ou lateral, ou as estruturas de colapso (Unidade 4, Anexo 1). Cada barra da escala $=10 \mathrm{~cm}$.

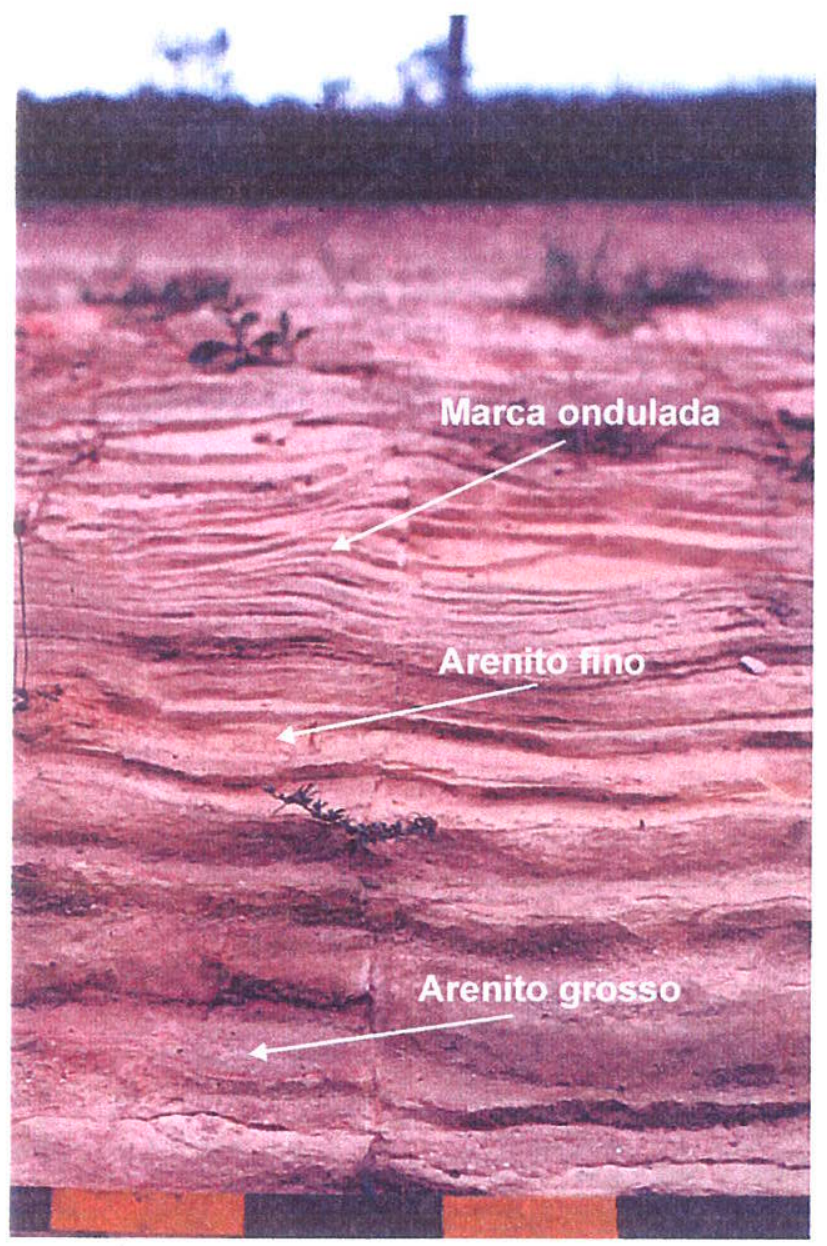

Figura IV-13: Arenito médio-fino com granodecrescência ascendente, associado a pequenos deltas lacustres. Notar marcas onduladas migrantes de pequeno porte, indicando regime de fluxo inferior (Unidade 4, Anexo 1). Cada barra da escala $=10 \mathrm{~cm}$. 


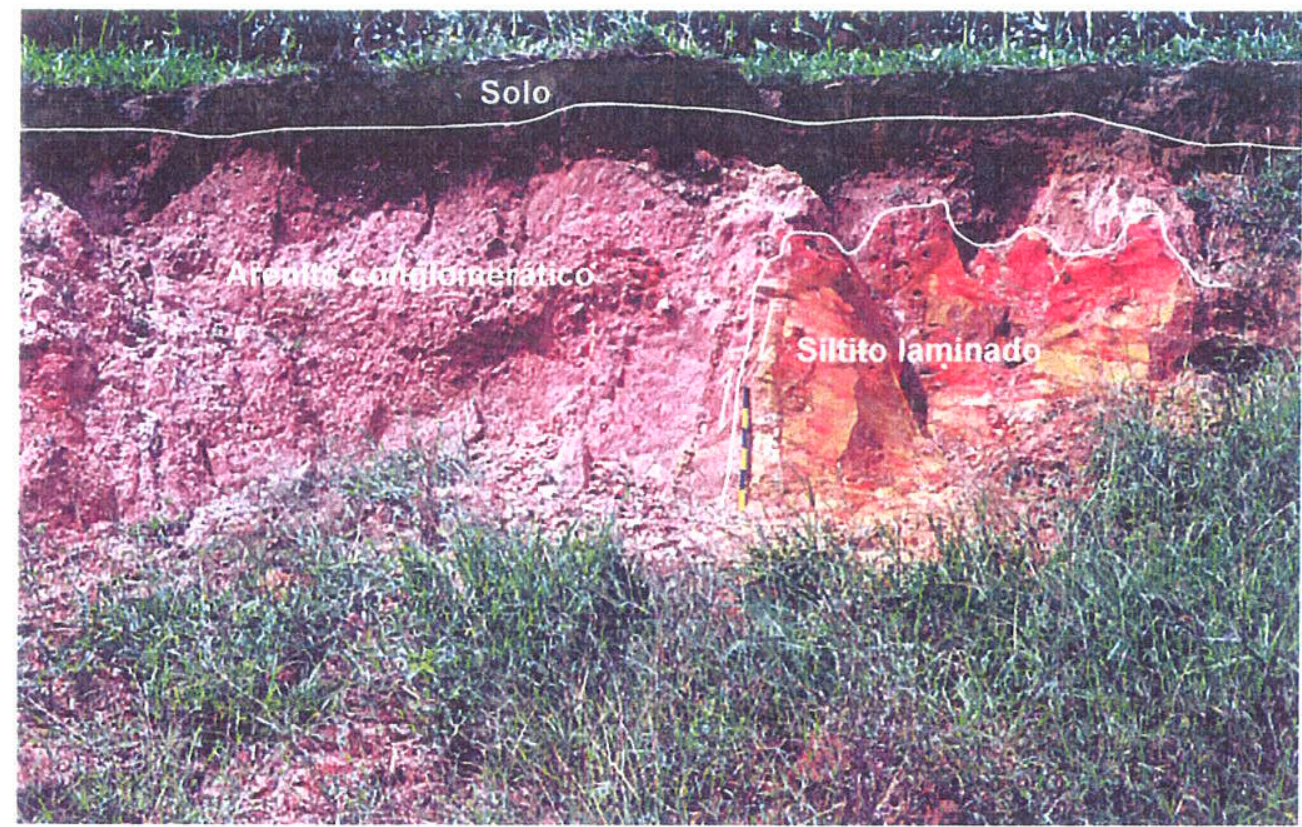

Figura IV-14: Arenito conglomerático, mal selecionado em contato por falha reversa de alto ângulo (colapso) com siltito laminado (Unidade 4, Anexo 1). Cada barra da escala $=10 \mathrm{~cm}$.

b) falhas reversas de baixo ângulo: caracterizados por ângulos menores que $45^{\circ}$, tendem a apresentar forma côncava da capa. Resultam de esforços horizontais de compressão, causados por escorregamento de sedimentos em rampas suaves (baixo ângulo) ou pelo deslocamento de uma geleira sobre os mesmos; e

c) falhas reversas de alto ângulo: apresentam ângulos maiores que $45^{\circ}$, forma convexa na porção inferior e aplainamento próximo à superfície, onde passam a falhas reversas de baixo ângulo. Esses falhamentos estão relacionados a movimentos verticais de dois elementos estruturais adjacentes, causados pelo deslocamento de um em relação ao outro.

McDonald e Shilts (1975) observaram essas estruturas em sedimentos flúvioglaciais da região proglacial do Pleistoceno canadense. Contudo, prováveis estruturas de colapso observadas na área estão associadas a depósitos flúvio e glácio-lacustres (Anexo 1), mas podem ser correlacionadas às estruturas observadas por McDonald e Shilts (1975), pois tanto a gênese, quanto a geometria dessas estruturas são semelhantes. 


\section{IV.3.2 - Feições periglaciais}

Estruturas presentes em alguns afloramentos de diamictito da área mapeada exibem similaridades morfológicas, litológicas, de dimensões e maneira de ocorrência com feições periglaciais descritas no Pleistoceno.

O termo periglacial é freqüentemente usado de maneira errônea na literatura nacional e mesmo internacional sobre depósitos glaciais antigos, para designar depósitos, estruturas e formas de terreno na verdade típicos do ambiente proglacial, isto é, situado em frente à margem de geleiras (=planície de lavagem glacial ou outwash plain). (Vide e.g., Bigarella et al., 1967.)

No sentido original (Lozinski, 1909 apud French, 1996), o termo periglacial designava condições climáticas e feições nelas formadas, adjacentes às capas de gelo pleistocênicas e recentes. No uso moderno, o termo periglacial abrange um amplo espectro de condições de clima frio e não-glaciais, apesar de normalmente estarem próximas às geleiras. Entretanto, condições climáticas periglaciais podem ser encontradas em regiões muito afastadas das margens de geleiras (e.g., Sibéria central e interior do Alasca) e em regiões de baixa latitude, mas de alta altitude (e.g., Platô do Tibete).

Há, contudo, dois critérios diagnósticos, sendo um ou ambos comumente presentes no ambiente periglacial. O primeiro é a oscilação congelamento-degelo do solo, associada à presença de água. O segundo é a presença de permafrost, solo e/ou rocha perenemente congelados. Utilizando esses critérios, estima-se que atualmente $25 \%$ da superfície terrestre experimenta, com maior ou menor intensidade, condições periglaciais (French, 1996).

$\mathrm{Na}$ região de Witmarsum, feições atribuiveis a origem periglacial foram identificadas em cinco localidades e em niveis estratigráficos distintos (Anexo 1), abrangendo cunhas de areia e compostas, clastos partidos e outras possiveis estruturas. Tendo em vista a provável predominância de facies glaciais terrestres durante a glaciação Gondvânica nesta porção da bacia do Paraná, era de se esperar que sedimentos formados durante fases de deglaciação do lobo Paraná pudessem exibir estruturas e/ou feições indicativas de clima periglacial. Contudo, apesar de serem relativamente comuns no Pleistoceno, há raras descrições de feições e depósitos interpretados como periglaciais no registro geológico das glaciações pré-pleistocênicas. Isso se deve às dificuldades de reconhecimento dessas feições, em relação a outras estruturas sedimentares sin- e pós-deposicionais, de ambientes glaciais e não-glaciais, como é o caso dos diques clásticos (Rocha-Campos et al., 1977). 
Um exemplo dessa dificuldade é visivel no debate ocorrido entre Spencer (1985) e Eyles et al. (1985). Spencer (1985) reconheceu em espesso pacote de diamictitos marinhos da Formação Port Askaig (Proterozóico Superior), na Escócia e leste da Groenlândia, feições em forma de cunha de arenito cortando verticalmente diamictito. Segundo o autor, essas estruturas (cunhas de areia) estão estratigraficamente associadas a conglomerados e superfícies de erosão que indicariam condições de exposição subaérea em ambiente periglacial (permafrost). A ausência de pavimentos estriados e de estruturas subglaciais sugere, segundo Spencer (1971, apud Eyles et al., 1985), que a capa de gelo possuía condições térmicas de base fria. Eyles et al. (1985) mostram que várias evidências existentes na Formação Port Askaig apontam para um ambiente glacio-marinho distal. Segundo os autores, estruturas no substrato, contatos, formas de relevo e sedimentos associados e caracteristicas geométricas da deposição de geleiras terrestres estão claramente ausentes no $700 \mathrm{~km}$ de exposição da Formação Port Askaig. Para Eyles et al. (1985), as estruturas poligonais irregulares, arenitos dobrados, diques irregulares e cunhas de areia, são atribuíveis a deformaçao sin-deposicional de sedimentos inconsolidados, formados por fluxo gravitacional de massa, subaquático, possivelmente acionado por terremoto.

Em resumo, portanto, a interpretação segura de feições periglaciais, deve estar calcada no exame minucioso não apenas da estrutura suspeita, mas também do contexto sedimentar que a engloba.

\section{IV.3.2.1 - Estruturas em cunha}

As estruturas em forma de cunha periglaciais resultam da contração termal do solo causada pelo frio intenso. Essas estruturas podem ser preenchidas por gelo/neve, areía ou material do próprio solo.

A formação de fendas no solo perenemente congelado é comumente atribuída à alternância de condições de congelamento e degelo. Esse fenômeno está diretamente associado ao comportamento da água no solo. A água doce, por exemplo, ao congelar expande cerca de $9 \%$ de seu volume. Essa caracteristica peculiar da água permite muitas considerações, mas apenas água pura, sob condições de 1 atmosfera de pressão e a $0^{\circ} \mathrm{C}$ de temperatura, permite esse efeito. No solo e/ou rocha as condições são diferentes.

Em condições normais, a água contém sais dissolvidos, exigindo que a temperatura caia para que haja o seu congelamento. Portanto, para se ter uma boa compreensão das circunstâncias que envolvem o congelamento de solos e/ou rochas, 
deve-se considerar as propriedades termodinâmicas da água e mecânicas do solo e/ou rocha (Williams e Smith, 1989).

A fase de transição, entre os estados liquido e sólido, é fundamental para se compreender a formação de solos congelados. A aplicação da energia livre de Gibbs é normalmente utilizada em estudos de fases de transição. Duas fases coexistem quando as energias livres são iguais. A temperatura abaixo do ponto de congelamento (freezing point), a energia livre do líquido, $\Delta \mathrm{G}_{\mathrm{L}}$, é maior que a do sólido, $\Delta \mathrm{G}_{\mathrm{S}}$ :

no ponto de congelamento $\Delta G_{S}=\Delta G_{L}$

abaixo do ponto de congelamento $\Delta G_{S}<\Delta G_{L}$

Duas fases de diferentes energias livres não podem coexistir em equilibrio. Em vez disso, a quantidade de energia livre da fase baixa é aumentada para gastar a que possui alta energia livre. Como a água contém sais, ocorre a diminuição da energia livre, que provoca o abaixamento do ponto de congelamento (depression of freezing point), provocando temperaturas mais baixas para que haja congelamento da água nos poros do solo e/ou rocha (Fig. IV-15).

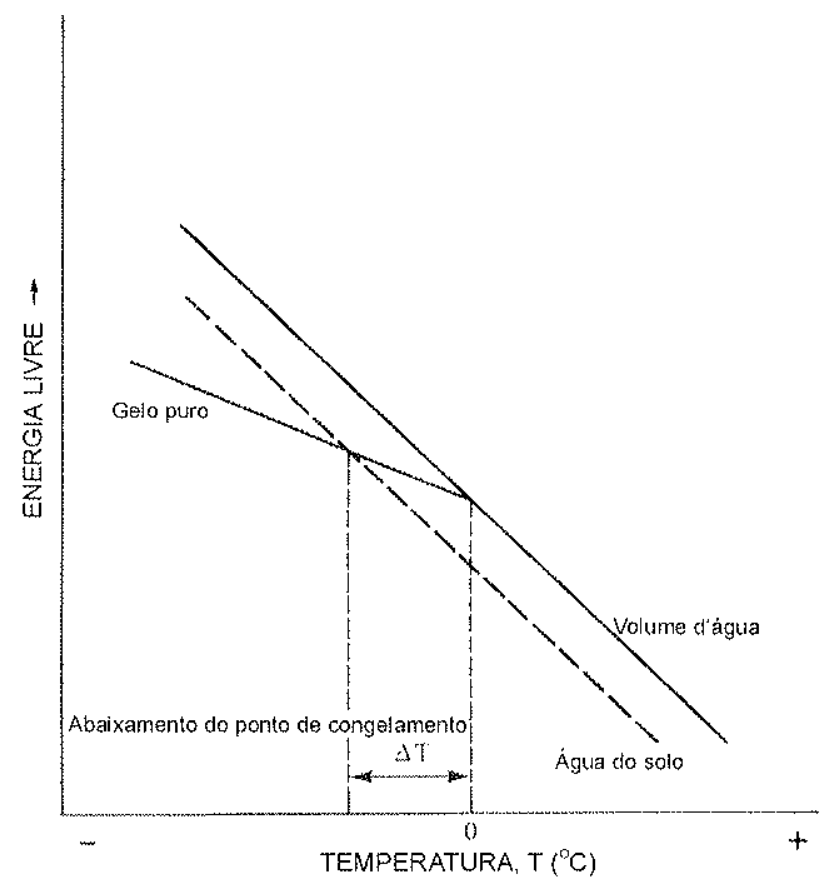

Figura IV-15: O gelo e a água normalmente coexistem a $0^{\circ} \mathrm{C}$. Mas, se a energia livre da água é reduzida (linha pontilhada) o ponto de congelamento é rebaixado por $\Delta \mathrm{T}$. Extraido de Williams $\mathrm{e}$ Smith (1989). 
Durante o processo de congelamento a água em estado líquido vai sendo progressivamente confinada em espaços cada vez menores, forçando sua migração da zona de congelamento, fenômeno chamado de criosucção. Normalmente, um filme de água separa as porções com gelo no solo e/ou rocha de partículas sólidas (Williams e Smith, 1989).

Existem, pelo menos, três tipos básicos de preservação de estruturas em cunha no registro geológico (Fig. IV-16): i) cunha com preenchimento secundário (ice wedge ou pseudomorfo de cunha de gelo); ii) cunha de preenchimento primário (sand wedge ou cunha de areia) e cunha composta (composite wedge).

Uma das características mais pronunciadas dos pseudomorfos de cunha de gelo preservadas do Pleistoceno é a estratificação dos sedimentos paralelamente às paredes das fissuras. Essas feições formam-se pelo derretimento gradual do gelo que preencheu as cunhas. Cunhas de areia contém, no geral, expressiva contribuição de sedimentos trazidos pelo vento, resultando em material de preenchimento bem selecionado e granulometricamente variando entre areia fina a média. Cunhas compostas, por sua vez, apresentam tanto preenchimento primário (areia e/ou material do solo escorregado para dentro da fissura), como secundário (gelo e/ou neve).

A única descrição de feições cuneiformes cuja origem é atribuída a clima periglacial no registro da glaciação Gondvânica da Bacia do Paraná deve-se a RochaCampos et al. (1977). As feições foram observadas na rodovia SP-280, próximas ao Municipio de Boituva, SP. As estruturas, de comprimento e largura variando, no geral, entre $1,6-3 \mathrm{~m}$ e de poucos centímetros a $80 \mathrm{~cm}$, intercalam-se subverticalmente em diamictito, a partir de contato erosivo entre este e diamictito superior. O preenchimento consiste de arenito fino a médio, às vezes conglomerático, particularmente na porção superior dos corpos. Os autores identificam as feições cuneiformes descritas como pseudomorfos de cunhas de gelo, relacionando-os a presença de solo perenemente congelado (permafrost), durante o Permo-Carbonífero. A ausência de estratificação vertical, entretanto, sugere tratar-se, mais provavelmente, de cunhas de areia.

As cunhas (wedges) observadas na área de Witmarsum cortam diamictito de matriz síltica, que são preenchidas por arenito médio e/ou fino, com estratificação horizontal ou maciços (cunhas de areia; Figs. IV-17; IV-18; IV-19 e IV-20), por diamictito e ambos (compostas). Alguns sand wedges observados não possuem a forma típica em cunha, como as descritas no Pleistoceno. Essa diferença pode estar relacionada à compactação imposta às estruturas, que as deformou. Essa característica também foi observada nas feições descritas por Rocha-Campos et al. (1977), no Estado de São Paulo. 
(a)

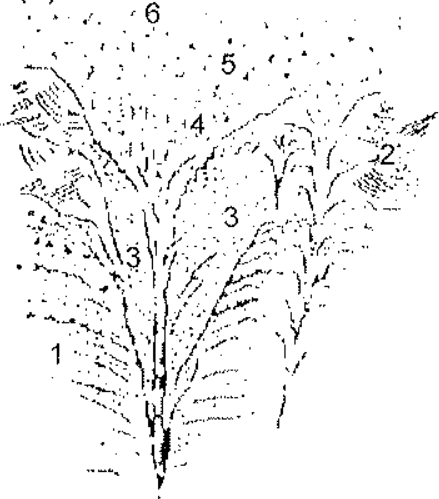

1 Areia médio estratificada 2 Areia com estratos cruzados

3 Areia média e fina

4 Clasto de argita

5 Areia

6 Areia e humus (superficie) (b)

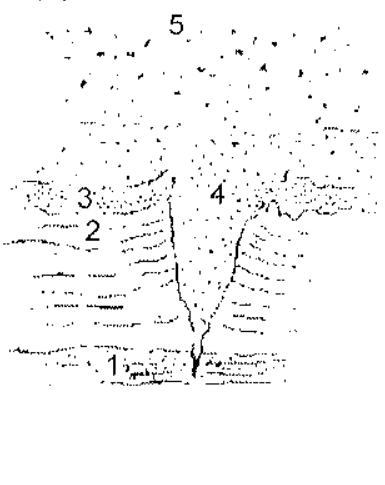

1 Areia média

2 Silte

3 Areia fina

4 Areia média e grossa

5 Areia e humus (superficie) (c)

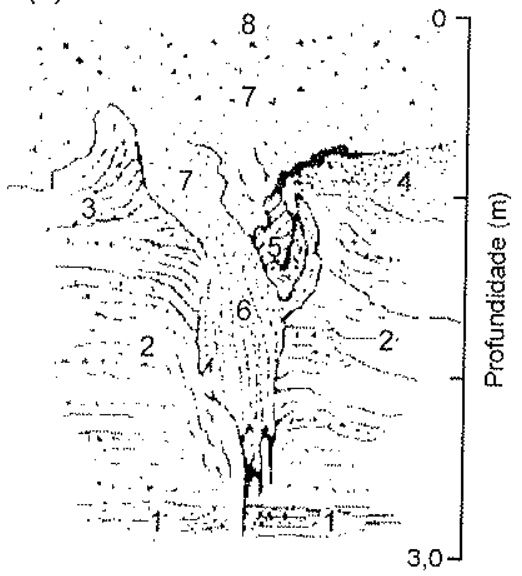

1,2,3 Areia média e grossa

com clastos

4 Arela siltica

5 Areia siltica e matéria orgânica

6 Areia média com estrutura foliada

7 Várias areias com seixos

8 Areia e humus (superficie)

(d)

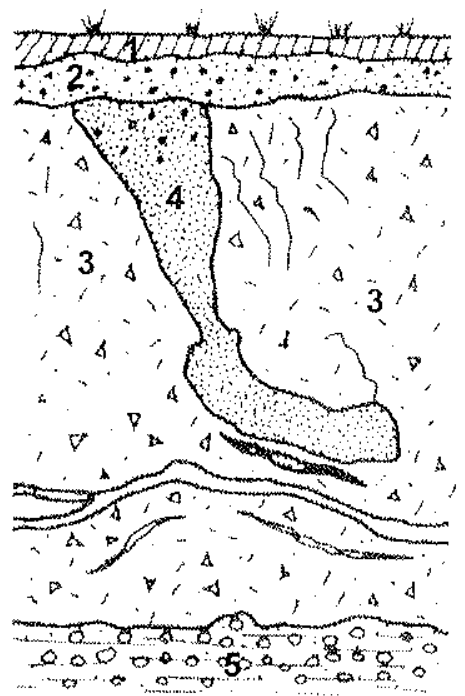

1 Camada de solo

2 Cascalho de ablaçäo

3 Diamictito (till)

4 Areia e cascalho preenchendo

estrutura em forma de cunha

5 Conglomerado

Figura IV-16: Exemplos de diferentes tipos de fendas de congelamento do Pleistoceno, região de Lód'z, Polônia central. (a) cunha de preenchimento secundário (pseudomorfo de cunha de gelo); (b) cunha de preenchimento primário (sand wedge); (c) cunha composta (composite wedge). (French, 1996.) Exemplo de cunha de areia da área de Wolverhampton (d), Inglaterra, com cerca de $1,5 \mathrm{~m}$ de comprimento (French, 1976). Notar similaridade com cunha de areia observada na Colônia Witmarsum (Fig. IV-19). 


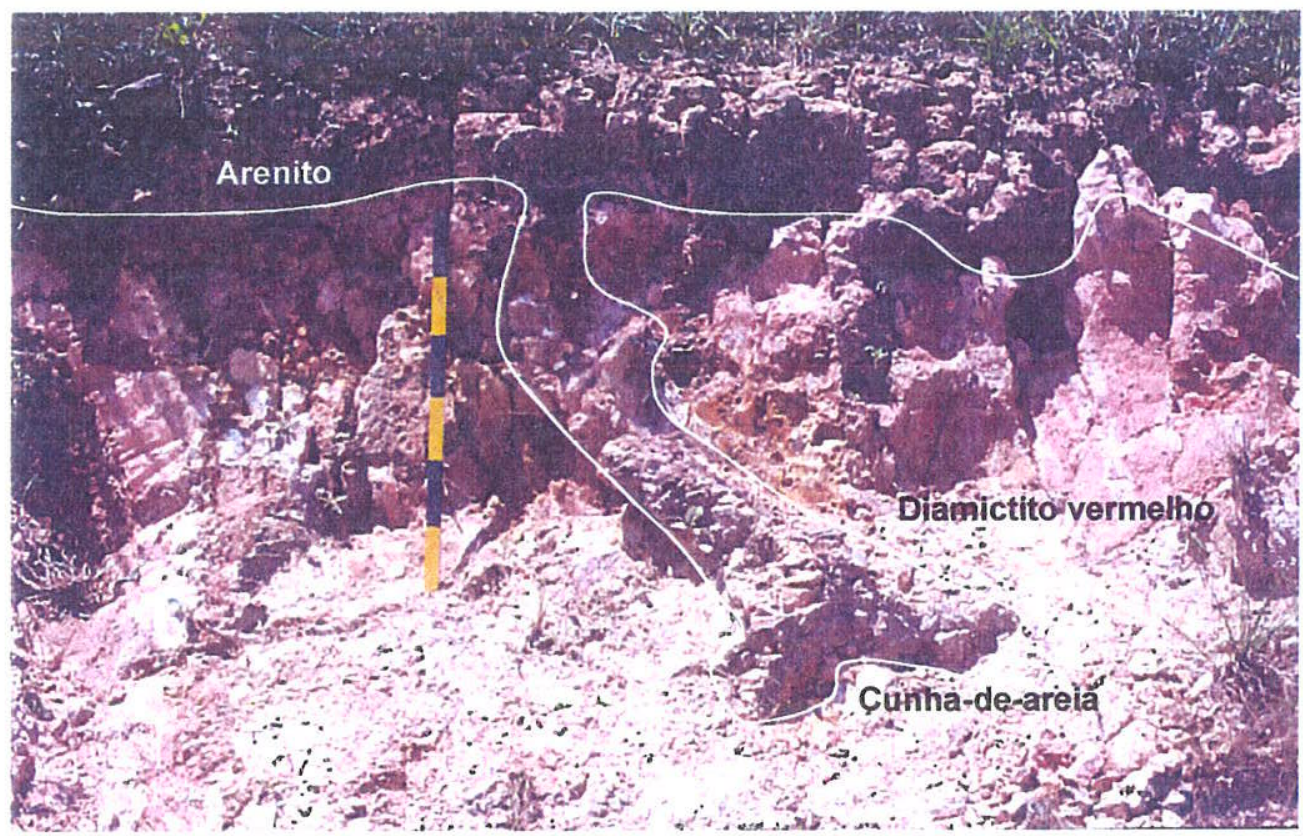

Figura IV-17: Cunha de areia (sand wedge) observada na área (Unidade 4, Anexo 3 e Fig. IV-19). A estrutura intercala-se em diamictito de matriz síltica, a partir de camada de areia que preencheu a fenda. Notar forma levemente dobrada, que pode ter sido causada pela compactação.

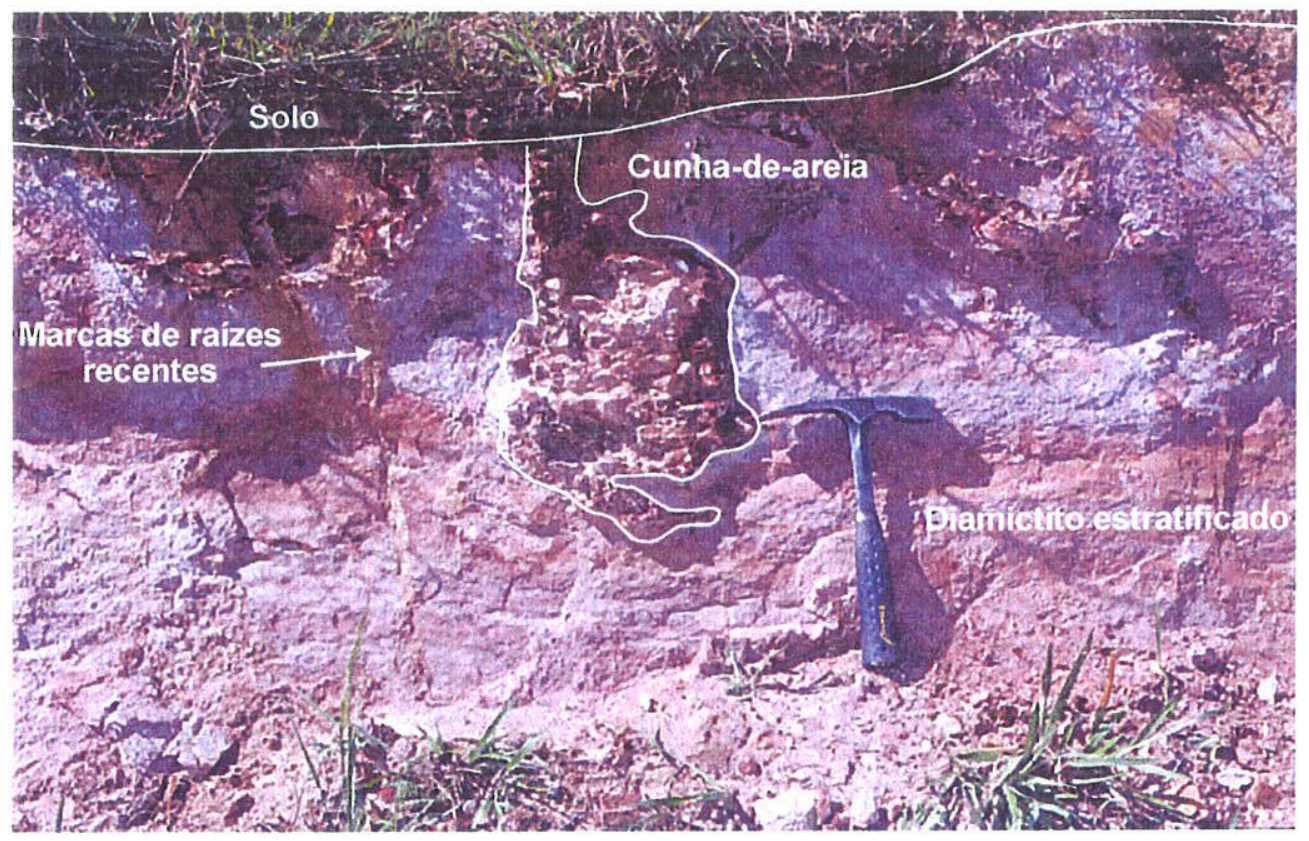

Figura IV-18: Cunha de areia em diamictito estratificado (Unidade 2, Anexo 3 e Fig. IV-20). Estratificação horizontal do arenito da cunha sugere preenchimento gradual da fenda. 


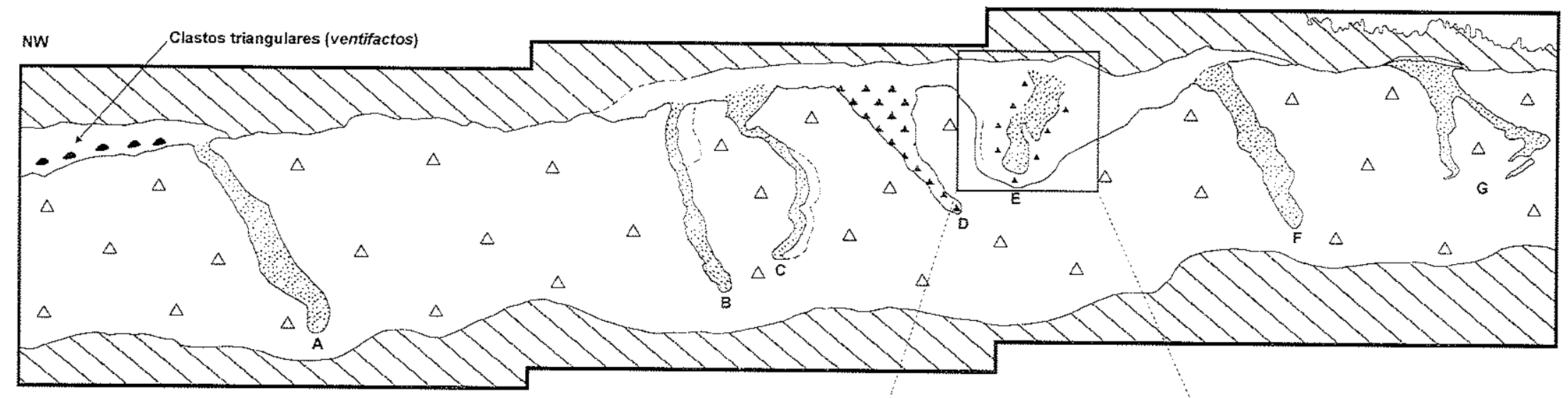

LEGENDA
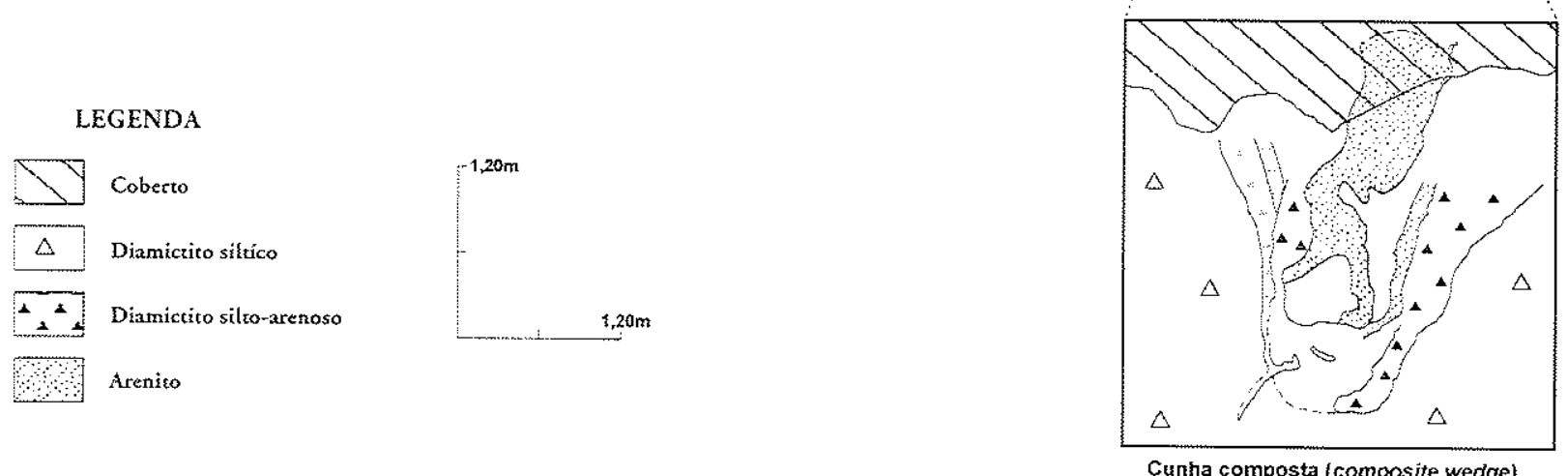

Figura IV-19: Esquema de afloramento situado na estrada de ligação à rodovia BR-277, onde foram identificadas 7 (sete) estruturas em forma de cunha (cunhas de areia e compostas). 

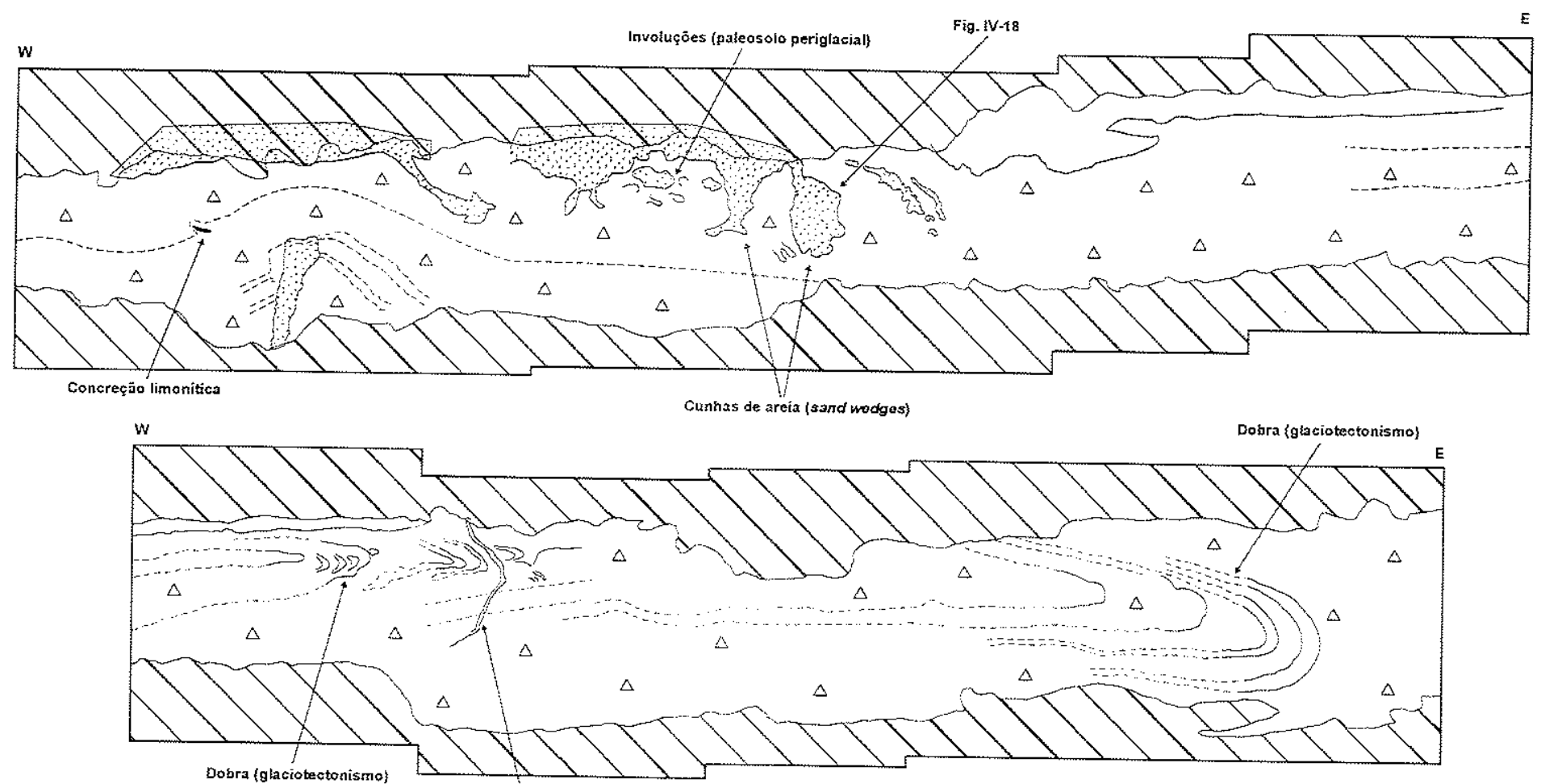

Dobra (glaciobectonismo)

Marca de raiz

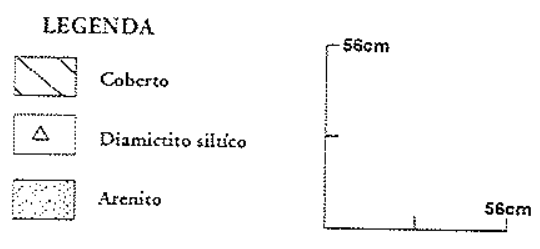

Figura IV-20: Afloramento, ao norte da área estudada, onde há exposição de estruturas e feições periglaciais. As estruturas ocorrem em diamictito siltoargiloso, estratificado e de cor vermelho-arroxeado e amarela. Além das cunhas de areia, também estão expostas estruturas semelhantes a involuçōes, o que representaria um paleosolo periglacial. 
A Figura IV-19 mostra o esquema de um dos afloramentos estudados, situado na estrada de ligação à rodovia BR-277 (Anexo 1). Nele foram identificadas 7 estruturas em forma de cunha, preenchidas por arenito, diamictito e ambos. A cunha $E$ mostra, no esquema de detalhe, várias camadas de diamictito paralelas à parede da fissura e na porção central da estrutura um corpo de arenito médio-grosso, trata-se, portanto, de uma cunha composta (composite wedge).

Outra característica marcante, descrita anteriormente, é a expressiva contribuição de sedimentos trazidos pelo vento, que preenchem fissuras recentes e do Pleistoceno. Sendo assim, era de se esperar que alguma evidência de atividade eólica fosse encontrada no afloramento e/ou na região estudada. Alguns indicios de que, pelo menos, parte dos sedimentos arenosos que preenchem as estruturas foram trazidos pelo vento, foram identificados em cascalheira que aflora logo acima das cunhas.

A cascalheira é formada por clastos centimétricos de arenito, semelhantes aos da cunha, e quartzo de veio, que também está presente no diamictito. Os clastos possuem seção triangular, e estão sendo interpretados com ventifactos mal formados, provavelmente, pelo pouco tempo de exposição à ação eólica. Se a interpretação acima estiver correta, pode-se concluir que pelo menos parte dos sedimentos (areias) que preenchem as estruturas foram trazidos pelo vento.

Em outro afloramento, ao norte da área estudada (Anexo 1 e Fig. IV-19), há exposições de novas estruturas e feições periglaciais. As estruturas ocorrem em diamictito silto-argiloso, estratificado, cor vermelho-arroxeado e amarela. Além das cunhas de areia (Fig. IV-18), que são semelhantes anteriormente descritas e que cuja estratificação horizontal sugere preenchimento gradual da fenda, também ocorrem estruturas semelhantes às involuções (Fig. IV-20), representando, portanto, um paleosolo periglacial.

\section{IV.3.2.2 - Clastos partidos}

Extensas superficies de fragmentos angulosos de rochas, comumente denominadas campo de blocos (block fields) na literatura européia, e kurums, na literatura russa, são exemplos dramáticos de desintegração e quebra mecânica de rochas por congelamento da água presente nos poros, juntas e planos de acamadamento (French, 1996). O fraturamento pode atingir a rocha do embasamento, mas afeta também clastos de tills, clastos caídos e cascalho flúvio-glacial, formando clastos partidos (frost wedged ou splitted clasts).

A geração dessas feições de congelamento e degelo está associada a diferença do coeficiente de dilatação térmica da água e da rocha. Como mencionado 
anteriormente, a água doce e pura expande cerca de $9 \%$ de seu volume quando congelada. Essa porcentagem decresce em condições naturais, se a água apresentar sais dissolvidos, o que acarreta na diminuição do seu ponto de congelamento.

Diversos pesquisadores acusam os ciclos congelamento-degelo como causa do fraturamento $e$, conseqüentemente, desintegração de rochas submetidas a baixas temperaturas. Entretanto, Hallet et al. (1991 apud French, 1996), usando amostras de arenito, inferiram que o congelamento induz à propagação de micro-fraturas sob temperaturas de $-3^{\circ} \mathrm{C}$ e $-6^{\circ} \mathrm{C}$. Portanto, o micro-fraturamento não requer ciclos congelamento-degelo, mas uma temperatura constante abaixo de zero. Waider e Hallet (1985; 1986 apud French, 1996) enfatizam que não são necessárias altas freqüências de ciclos congelamento-degelo para a propagação de rachaduras, pois estas podem ocorrer em temperaturas entre $-4^{\circ} \mathrm{C}$ e $-15^{\circ} \mathrm{C}$.

Vários clastos coletados na área mapeada apresentam-se partidos por série de fraturas paralelas ou obliquas, porém com as fatias de rocha aderidas umas as outras ("coladas"), pela deposição secundária de cimento silicoso. A maioria é de arenito, provavelmente da Formação Furnas, e de quartzito. Quanto à forma, os clastos, no geral, são facetados, alguns com lineações que sugerem estrias glaciais, centimétricos, tabulares (ou oblatos) e isoaxiais.

As fraturas normalmente acompanham a estratificação presente na rocha. Em apenas um clasto, que aparenta ser maciço, o fraturamento é independente da estrutura. Outra característica comum dos clastos é a preferência das fraturas cortarem seu eixo menor. Também ocorrem clastos capeados por uma fina camada de limonita (Fig. IV-21).

Os clastos partidos estão localizados em afloramento na Fazenda Schroeder (Anexo 1), onde ocorrem na superfície de corpo pouco espesso de diamictito arenoso, rico em clastos centimétricos a milimétricos, situado sobre extensa superfície estriada, sulcada e deformada de arenito da Formação Furnas. As seguintes hipóteses foram levantadas visando esclarecer a gênese desses clastos.

a) Variação de temperatura atual

Apesar de os clastos ocorrerem na superficie de diamictito recém-exposto por escavação artificial do afloramento, examinou-se a possibilidade deles terem sido fraturados por variação da temperatura atual da região. 


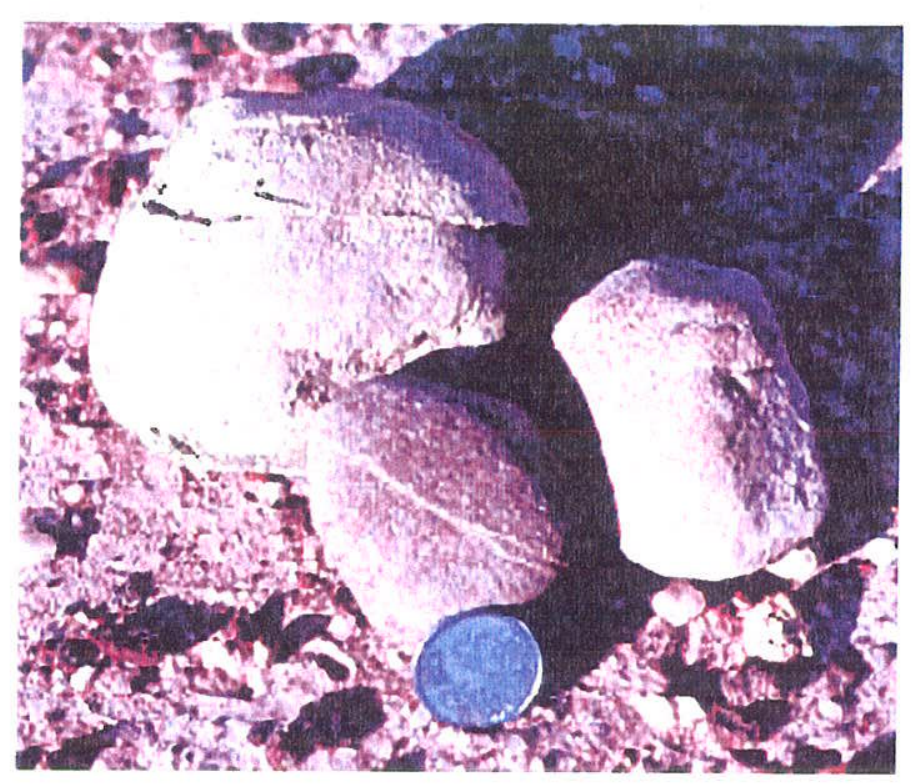

Figura IV-21: Clastos partidos observados em campo, notar ligeiro deslocamento causado pelo fraturamento no clasto maior à esquerda. Fazenda Schroeder (Unidade 2, Anexo 1).

A Tabela IV-1 mostra as temperaturas mínimas e máximas registradas nos anos de 1999 e 2000 , bem como o $\Delta \mathrm{T}$. O maior $\Delta \mathrm{T}$ registrado no ano de 1999 foi de $16^{\circ} \mathrm{C}$ no mês de agosto e de $15^{\circ} \mathrm{C}$ em abril de 2000 .

Vale ressaltar que a temperatura do ar não pode ser extrapolada diretamente para a da rocha. Em alguns casos, dependendo do tipo de rocha, pode-se esperar temperaturas máximas mais altas que as registradas no ar (Debenham, 1921 e Thorn, 1988 apud Hall, 1997).

Tabela IV-1: Temperatura mínima, máxima e $\Delta \mathrm{T}$ dos anos de 1999 e 2000. Temperatura em ${ }^{\circ} \mathrm{C}$.

\begin{tabular}{|c|c|c|c|c|c|c|c|c|c|c|c|c|}
\hline 1999 & Jan & Fev & Mar & Abr & Mai & Jun & Jul & Ago & Set & Out & Nov & Dez \\
\hline mínima & 18 & 19 & 18 & 14 & 12 & 12 & 10 & 08 & 12 & 14 & 14 & 16 \\
\hline máxima & 28 & 28 & 28 & 26 & 24 & 22 & 24 & 24 & 24 & 22 & 24 & 27 \\
\hline$\Delta T$ & 10 & 09 & 10 & 12 & 12 & 10 & 14 & 16 & 12 & 08 & 10 & 11 \\
\hline
\end{tabular}

\begin{tabular}{|c|c|c|c|c|c|c|c|c|c|c|c|c|}
\hline 2000 & Jan & Fev & Mar & Abr & Mai & Jun & Jul & Ago & Set & Out & Nov & Dez \\
\hline mínima & 17 & 17 & 17 & 13 & 13 & 13 & 08 & 10 & 12 & 16 & 16 & 17 \\
\hline máxima & 28 & 27 & 27 & 28 & 26 & 26 & 22 & 24 & 24 & 26 & 27 & 28 \\
\hline$\Delta \mathrm{T}$ & 11 & 10 & 10 & 15 & 13 & 13 & 14 & 14 & 12 & 10 & 11 & 11 \\
\hline
\end{tabular}


No caso em pauta, a variação da temperatura medida é relativamente pequena e ocorreu durante período longo, principalmente quando comparada com regiões de clima periglacial atuais (Tabela IV-2). Nessas regiões, além das diferenças de temperatura serem maiores, as temperaturas médias estão geralmente abaixo de zero. Mesmo que o fraturamento fosse atual, a hipótese não explicaria o fato de os clastos estarem hoje soldados.

Tabela IV-2: Variação anual de temperatura em regiões com clima periglacial atual (French, 1996). Temperaturas em ${ }^{\circ} \mathrm{C}$.

\begin{tabular}{|c|c|}
\hline Localidades & $\Delta \mathrm{T}$ \\
\hline Spitsbergen, Green Harbour & 21 \\
\hline Canadá Artico, Sachs Harbour & 32 \\
\hline Sibéria Central, Yakutsk & 62 \\
\hline Yuokon, Canadá, Cidade de Dawson & 45 \\
\hline Alpes, Sonnblíck \\
3060 m & 15 \\
\hline Rockies, Niwot Ridge, \\
3750 m
\end{tabular}

b) Fraturamento tectônico

Outra hipótese levantada é que o falhamento transpressivo, descrito no Capítulo 1.3.1, possa ter ocasionado o fraturamento dos clastos (Fig. IV-22). A ocorrência de clastos não fraturados e a orientação caótica destes no afloramento, provavelmente exclui essa possibilidade.

c) Congelamento - degelo

Aparentemente, esta é a hipótese que melhor se encaixa aos dados de campo. A oscilação congelamento-degelo ou apenas o congelamento da água presente nos poros e planos de fraqueza, teria sido a causa do fraturamento observado nos clastos. Um aspecto ainda pouco claro é se os clastos foram incorporados pela geleira já fraturados e reconstituidos, sendo posteriormente depositados no till, ou se o fraturamento e cimentação ocorreu após deposição do till (Fig. IV-23), sendo a segunda opção a mais provável. 


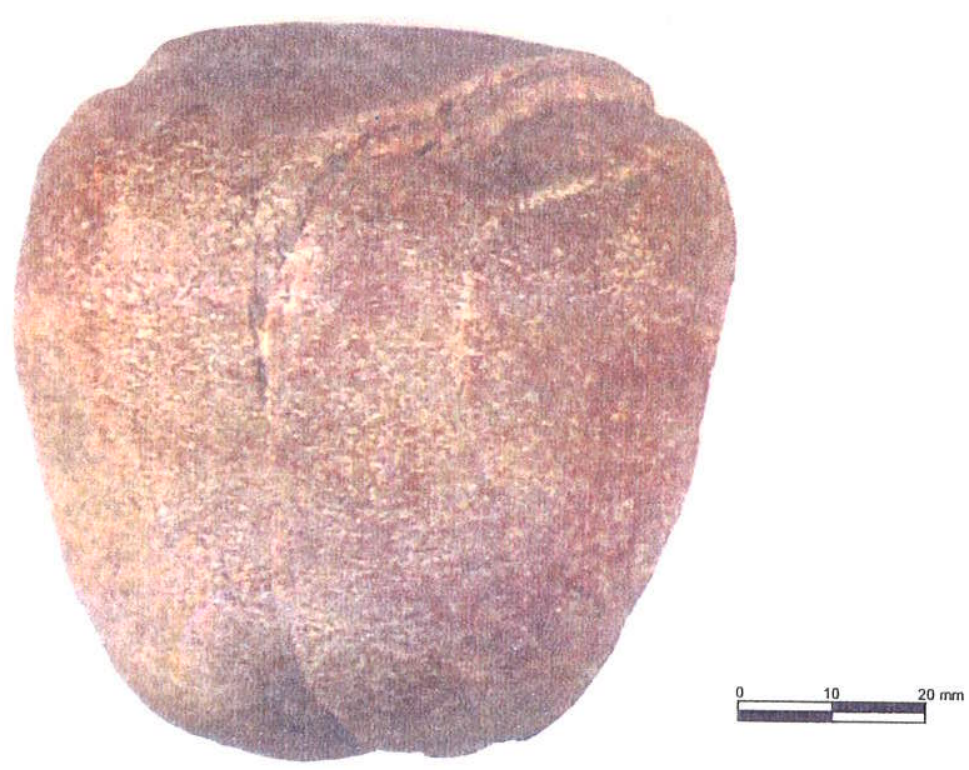

Figura IV-22: Clasto de arenito Furnas partido. O fraturamento segue estratificação e ocasionou pequeno deslocamento de partes do clasto. Fazenda Schroeder (Unidade 2, Anexo 1).

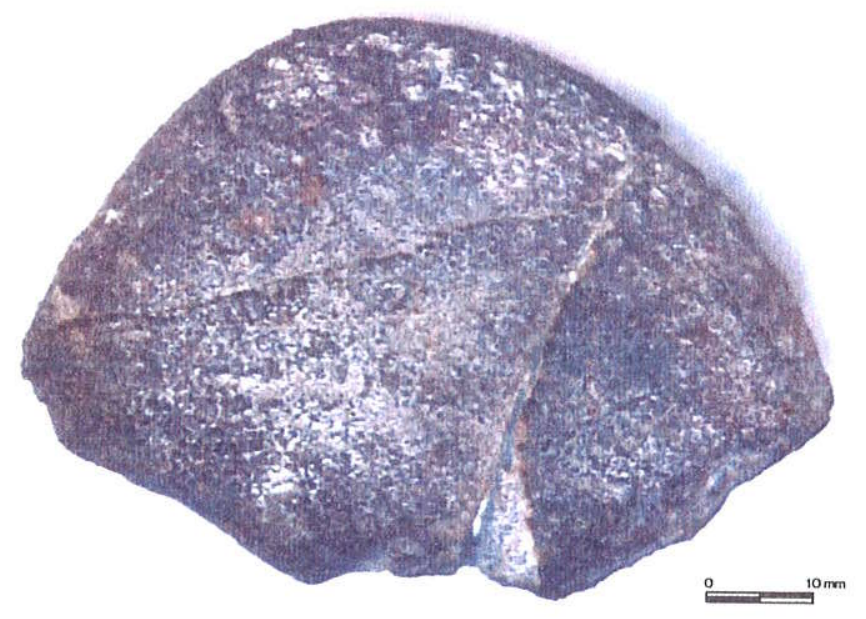

Figura IV-23: Clasto partido com película de limonita. Notar duas fraturas cortando eixo menor do clasto. Fazenda Schroeder (Unidade 2, Anexo 1).

\section{IV.4.3 - Outras feições glaciais e periglaciais fotointerpretadas}

Características morfológicas são corriqueiramente utilizadas no estudo de feições glaciais e periglaciais do Pleistoceno e recentes, e utilizadas na classificação das estruturas (e.g.: drumlins, flutes, kames, kettles, mounds).

A porção oeste da área mapeada apresenta diversas estruturas circulares e lineares, que se assemelham a formas de relevo observadas em regiões deglaciadas pleistocênicas e atuais, como por exemplo pingos e/ou mounds. 
Feições coliniformes constituídas de diamictito deformado, que parecem ocorrer em faixas paralelas, orientadas normalmente à movimentação da geleira permocarbonífera, correspondem a morainas de empurrão (push moraines) (Fig. IV-24), descritas anteriormente.

Sendo assim, conclui-se que a área foi exposta a períodos de condições climáticas rigorosas, com temperaturas médias abaixo de zero, como as atualmente encontradas em regiões periglaciais.

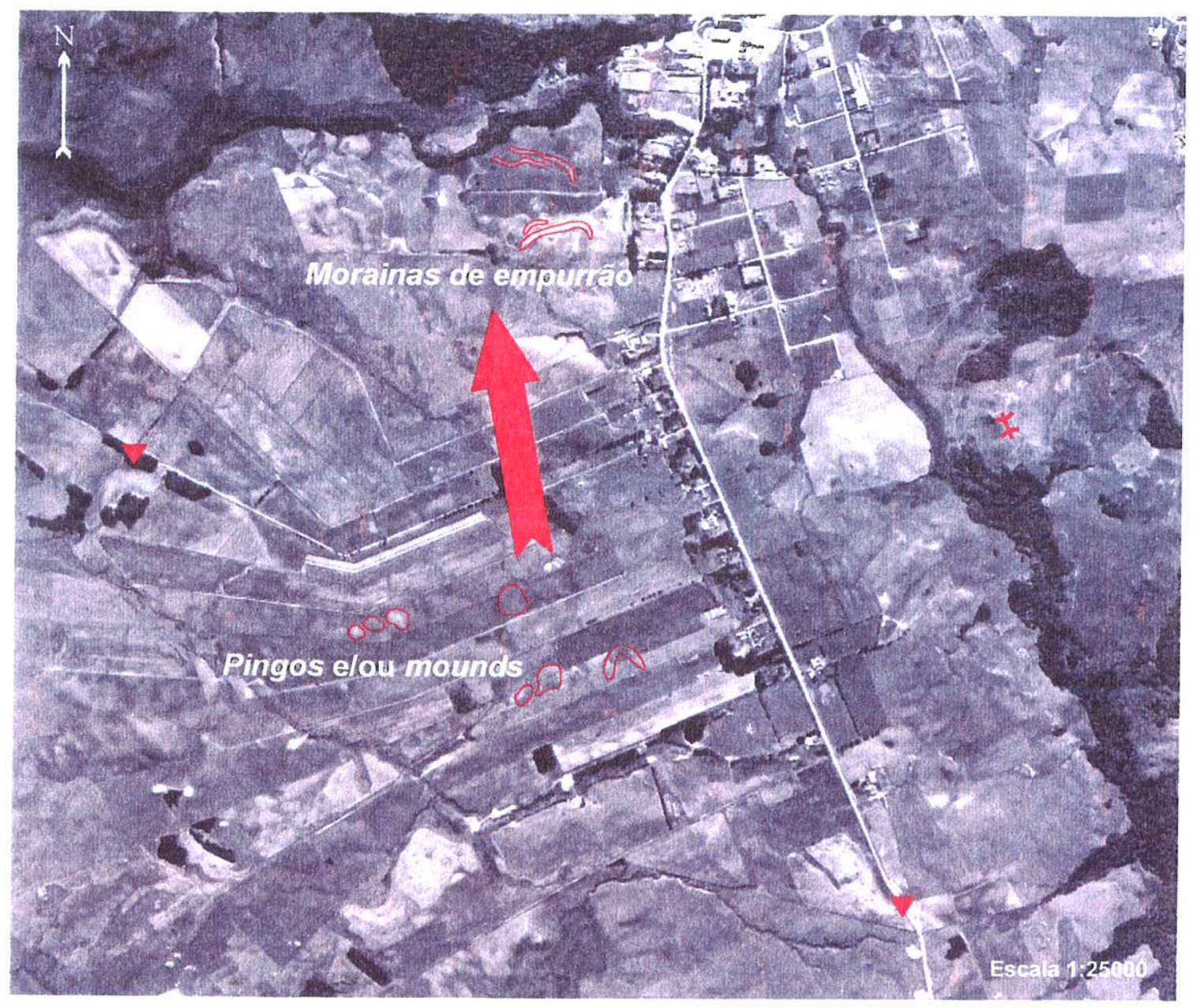

Figura IV-24: Fotointepretação de algumas feições glaciais e periglaciais com morfologia preservada (morainas de empurrão e pingos). Também estão marcadas cunhas de areia (triângulos invertidos vermelhos) e superfícies estriadas no topo do Morro Siebert (símbolo em vermelho). Seta maior indica o sentido de movimento da geleira. 


\section{V -FENÔMENOS GLACIAIS E A EVOLUÇÃO TECTONO-SEDIMENTAR DO ARCO DE PONTA GROSSA}

\section{V.1 - Evolução tectono-sedimentar do arco de Ponta Grossa}

Uma das questões investigadas na presente dissertação refere-se ao esclarecimento da paleogeografia e paleofisiografia da área do arco de Ponta Grossa e suas relações com a história glacial neopaleozóica. Esse estudo foi inicialmente motivado pela profusão de superfícies e pavimentos estriados glacialmente que ocorrem na área, tanto sobre o embasamento Devoniano, quanto sobre e intraformacionais em rochas do Subgrupo Itararé e a suposta faciologia glacial terrestre dos diamictitos associados as formas de terreno glácio-erosivas.

Frakes e Crowell (1972) e Santos et al. (1996) postularam a existência de um lobo glacial do manto de gelo de Windhoek, que atingiu o centro-sul do Estado do Paraná (lobo Paraná) movimentando-se de sul para norte, sobre a área do atual arco de Ponta Grossa.

A morfologia atual do arco de Ponta Grossa foi, entretanto, adquirida principalmente no Mesozóico, estando associada ao vulcanismo básico juro-cretácico (Formação Serra Geral). Contudo, existem evidências de um comportamento positivo pré-Mesozóico da região (Santos, 1987). A elevação tectônica da área deve, portanto, ter alterado a configuração da margem neopaleozóica da Bacia do Paraná. Como resultado, as reconstituições paleogeográficas mostram a situação aparentemente estranha do lobo Paraná, movendo-se no sentido S-N, obliquamente ao eixo do atual arco de Ponta Grossa.

Vários autores demonstraram a ocorrência de "alinhamentos estruturais" correspondentes a falhas SE-NW cortando a área do arco de Ponta Grossa (Medeiros et al., 1971; Vieira, 1973; Ferreira et al., 1981; Ferreira, 1982). Segundo Santos et al. (1996) e Eyles et al. (1993), esses falhamentos ter-se-iam movimentado diferencialmente durante o Paleozóico e Mesozóico, provocando o deslocamento lateral de áreas rebaixadas e elevadas (chamado de estilo piano keyboard). Tendo em vista o controle exercido pela topografia sobre a dinâmica das massas de gelo, torna-se relevante tentar entender as características de relevo e fisiografia da área de estudo em relação a paleogeografia glacial e, nesse contexto, a formação, preservação e exumação da paisagem glacial erosiva neopaleozóica.

A pesquisa fundamenta-se no exame comparativo de dois tipos de dados geológicos: 
i) mapas de isoespessura da Formação Furnas e do Subgrupo Itararé totais e relativos aos intervalos bioestratigráficos em que se subdivide a segunda unidade; e

ii) curvas de subsidência da Bacia do Paraná, relativos ao Subgrupo Itararé, elaborados a partir de dados de poços de sondagens.

A comparação entre os mapas de isoespessura total do Subgrupo Itararé de Northfleet et al. (1969), Santos (1987); Zalán et al. (1990) e Santos et al. (1996), demonstra, apesar das nitidas diferenças entre eles, que o arco de Ponta Grossa teve função importante na sedimentação durante o permo-carbonifero. Perfis de variação de espessura, na região central e porção sul do arco de Ponta Grossa, mostram que a primeira área sofreu subsidência mais intensa (Fig. V-1), fato este observado nos quatro trabalhos listados. Northfleet et al. (1969), foram os primeiros a apontar que os sedimentos do Subgrupo Itararé depositados sobre o arco de Ponta Grossa, por serem mais arenosos do que nas duas depressões laterais ao arco, ao sul de São Paulo e norte de Santa Catarina, sugerem origem continental.

Medeiros et al. (1971), subdividem o Subgrupo Itararé em 3 (três) grandes intervalos (inferior, médio e superior) e propõem a existência de feições paleoestruturais, através de mapa de isoespessura, orientadas na direção NNW-SSE, que representariam a paleotopografia da superfície pré-Itararé (Devoniano + Embasamento).

$O$ intervalo inferior corresponderia ao intervalo bioestratigráfico $G$ de Daemon e Quadros (1970) (Carbonífero Superior - Estefaniano.) Segundo os autores os sedimentos correspondentes estão ausente na região sudeste da bacia, devido à ação erosiva das geleiras, cujo deslocamento SE-NW é indicado pela orientação de estrias glaciais descritas por Bigarella et al. (1967). Já o intervalo médio, em cuja base encontram-se corpos de arenito fluvial, em forma de canais alongados, sinuosos, de grande porte, como o arenito Lapa (França et al., 1996; Canuto et al., 1996; 1997; Trosdtorf Jr., 1998; 2000), corresponderia ao intervalo bioestratigráfico $\mathrm{H}$ de Daemon e Quadros (1970). Medeiros et al. (1971), indicam ainda que nesta época ocorreu o surgimento do arco de Ponta Grossa como uma feição bastante ativa na Bacia do Paraná, influenciando a sedimentação e provocando erosão e não deposição. Esta interpretação é adotada por Daemon e Quadros (1970) e posteriormente confirmada por Santos (1987). 

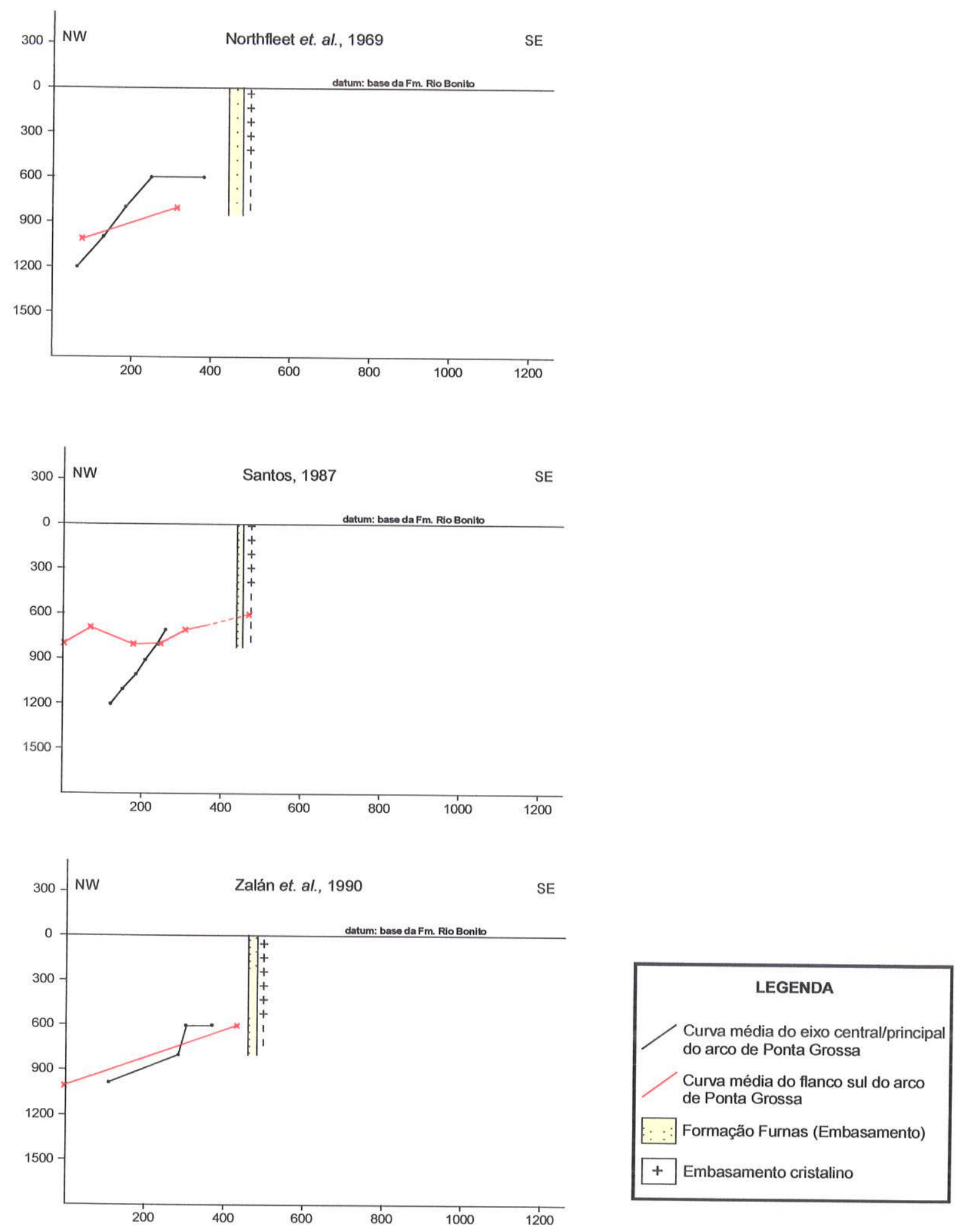

Figura V-1: Projeção da espessura do Subgrupo Itararé em direção ao arco de Ponta Grossa. Note-se maior intensidade da subsidência da porção sul da estrutura. Dados extraídos de: A) Northfleet et al. (1969); B) Santos (1987); e C) Zalán et al. (1990). 
Vieira (1973) propôs, pioneiramente, a ocorrência de comportamento estrutural diferenciado na região do arco de Ponta Grossa, subdividindo-a em quatro regiões/faixas, separadas por três grandes zonas de falhas: Rio Alonzo, São Jerônimo-Curiuva e Serra da Fartura. Segundo o autor, ao longo da história geológica da região registra-se, entretanto, uma única fase tectônica ocorrida nos primórdios do período Cretáceo, sendo os períodos precedentes caracterizados apenas por movimentos ascensionais e descendentes localizados. Essas idéias diferem das de Northfleet et al. (1969), segundo os quais o arco de Ponta Grossa teria sofrido o máximo arqueamento no Permiano inferior, afetando principalmente a distribuição dos sedimentos do Subgrupo Itararé.

Ferreira (1982) subdivide o arco Ponta Grossa em três segmentos principais, separados pelos alinhamentos estruturais detectados a partir de dados aeromagnéticos e geológicos (Fig. V-2). O limite setentrional do arco de Ponta Grossa seria representado pelo Alinhamento Estrutural de Guapiara, definido por Ferreira et al. (1981). A região central da estrutura seria limitada pelos alinhamentos de São Jerônimo-Curiuva e Rio Alonzo (Fig. V-2), e caracterizada por alta concentração de diques básicos, que se estendem até aos terrenos pré-cambrianos a leste. O limite meridional do arco de Ponta Grossa, por sua vez, é representado pelo Alinhamento Estrutural do Rio Piquiri. Segundo A. Bartorelli (informação verbal apud Ferreira, 1982) o alinhamento corresponde a extensa zona de falhamentos transcorrentes.

Pelo acima discutido vê-se que até o final do Permiano Inferior, toda a área entre os alinhamentos de São Jerônimo-Curiúva e Rio Alonzo, corresponderia a um alto estrutural que compartimentava a bacia na região hoje ocupada pelo arco de Ponta Grossa, separando uma zona mais subsidente ao norte (sub-bacia de São Paulo) e a sub-bacia em Santa Catarina e Paraná, ao sul.

A interpretação de Ferreira (1982), apesar de calcada em mapas de isoespessura de diversos autores, deve ser considerada com cautela, já que o autor utiliza somente dados referentes à espessura total dos sedimentos do Subgrupo Itararé. Uma análise minuciosa da história da subsidência neopaleozóica pode ser feita através do mapeamento de isoespessura dos intervalos bioestratigráficos do Subgrupo Itararé. Dados apresentados por Daemon e Quadros (1970), para o intervalo I (Fig. V-3C) demonstram que a região posteriormente ocupada pelo arco de Ponta Grossa contém depósitos formados nesse intervalo. 


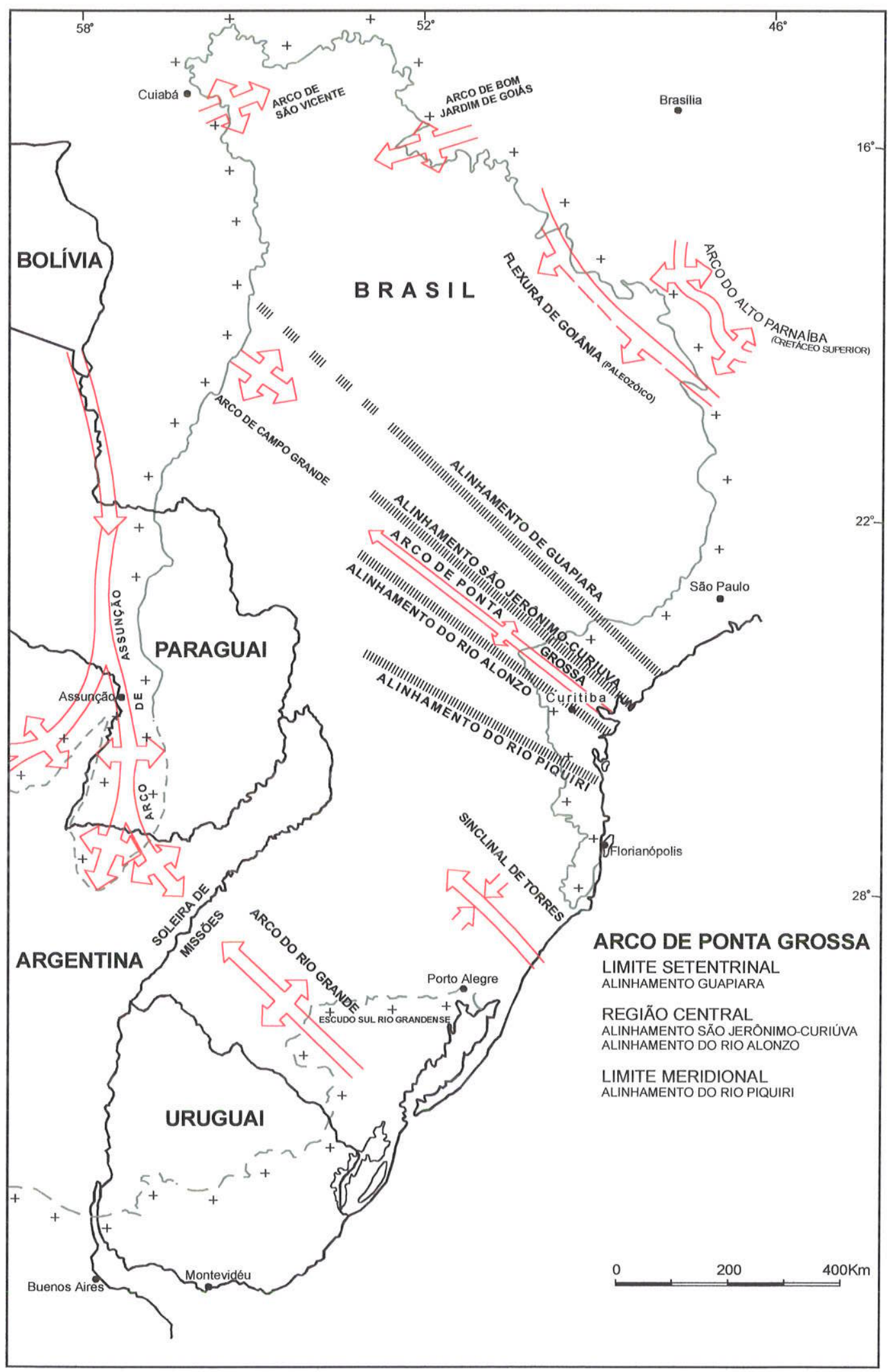

Figura V-2: Alinhamentos estruturais detectados por levantamentos aeromagnéticos e geológicos que compõem o arco de Ponta Grossa (Ferreira, 1982). 

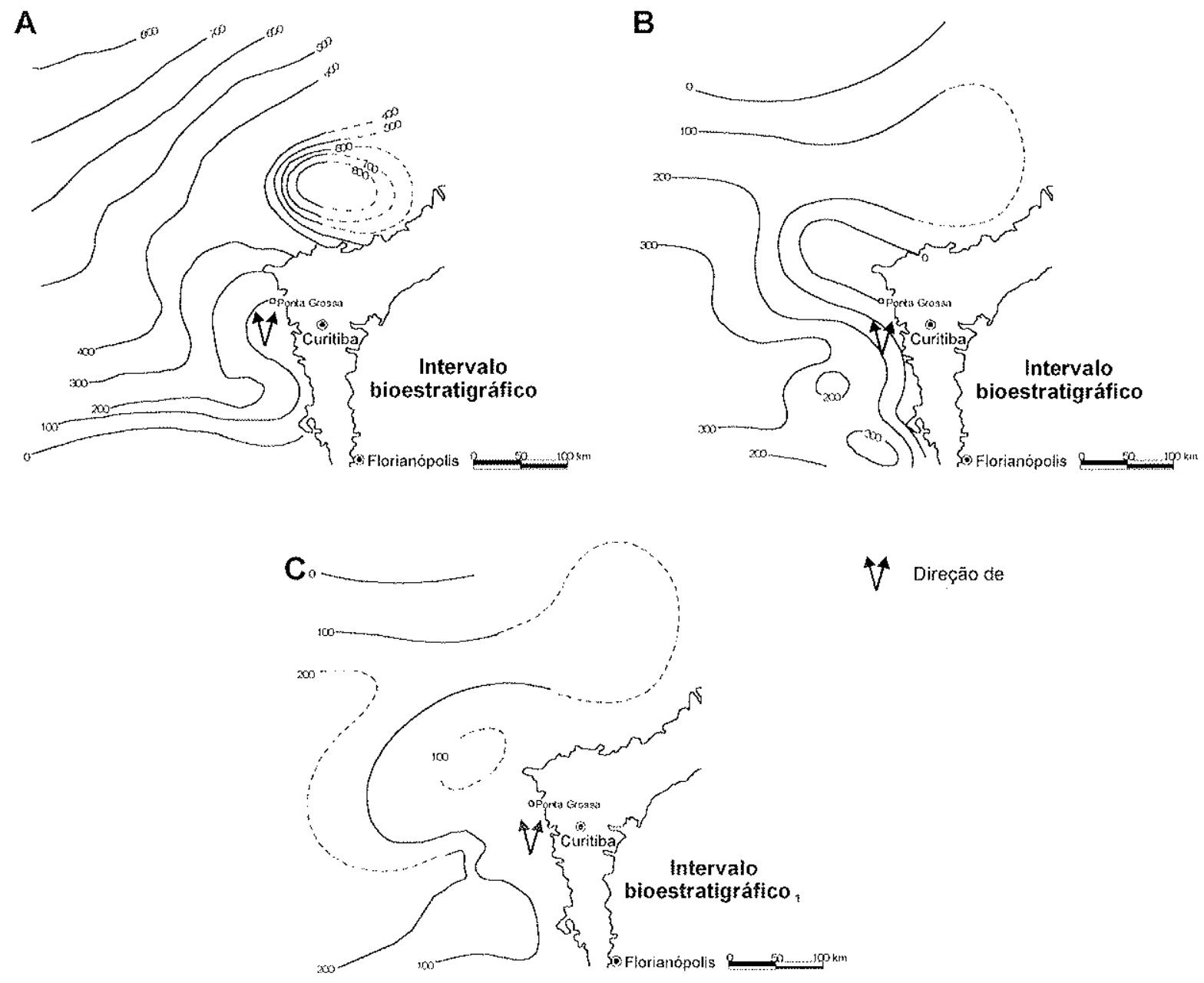

$\checkmark$ Direçäo de

Figura V-3: Mapas de isoespessura dos intervalos bioestratigráficos $G, H$ e $\mathrm{I}_{\mathfrak{1}}$ (Daemon e Quadros, 1970).

Medeiros et al. (1971) também confirmam o desenvolvimento de duas sub-bacias separadas pelo arco de Porto União (ENE-WSW), poucos quilômetros ao sul do Alinhamento Estrutural do Rio Alonzo, na região entre Porto União e Canoinhas. Segundo eles a região entre os Alinhamentos de São Jerônimo-Curiuva e Rio Alonzo, apesar de apresentar menor taxa de subsidência, não seria o divisor entre as duas sub-bacias, como preconizado por Ferreira (1982), situando-se este mais ao norte.

Fúlfaro et al. (1980), concluem que a reaglutinação e sutura de placas durante formação do Supercontinente Pangea, no Carbonífero, provocou um soerguimento generalizado na Bacia do Paraná, causando o falhamento do Grupo Paraná (Devoniano) e erosão de parte não estimada da coluna sedimentar, durante todo o Carbonífero Inferior. Sendo assim, o eixo deposicional da bacia deslocou-se mais para o norte, 
localizando-se entre os alinhamentos de São Jerônimo-Curiúva (Vieira, 1973) e do Rio Tietê (Saad, 1977).

Segundo os mesmos autores, ao redor do atual arco de Ponta Grossa, observa-se nítido controle deposicional exercido por alguns alinhamentos à época da deposição, bem como um centro dispersor de sedimentos da Formação Rio Bonito.

Fúlfaro et al. (1980), ainda argumentam que o início do permocarbonifero (Série Tietê Inferior) guarda forte controle dos limites das antigas calhas aulacogênicas, precursoras da Bacia do Paraná, como indicado pela distribuição e maior espessura de sedimentos na direção NW - SE (Fig. V-4). Essas feições também estão nitidamente visíveis no mapa de isoespessura do intervalo $G$ (Sakmariano) de Santos (1987). (Fig. V$5 A$.)

Santos (1987), faz uma análise detalhada da sedimentação permo-carbonifera na Bacia do Paraná com base em dados de poços perfurados pela PETROBRÁS e PAULIPETRO, com referência aos intervalos bioestratigráficos $G, H_{1} I_{1}$ e $I_{2-4}$, em que Daemon e Quadros (1970) subdividem o Subgrupo Itararé.

Para Santos (1987), a região atualmente ocupada pelo arco de Ponta Grossa foi sede de intenso tectonismo, atuando como fonte de sedimentos para o Subgrupo Itararé no intervalo G. Segundo o autor a sedimentação do Subgrupo Itararé/Grupo Aquidauana, neste intervalo, foi de natureza predominantemente continental. As porções norte, nordeste e oeste da Bacia do Paraná, durante o intervalo H (Fig. V-5B), permaneceram elevadas e provavelmente submetidas a processos de erosão. Sendo assim, sobre o arco de Ponta Grossa, o intervalo I repousa diretamente sobre o G (Fig. V-6).

Santos et al. (1996) aponta a existência de alto estrutural localizado na área do futuro arco de Ponta Grossa que teria servido de barreira parcial para a transgressão marinha vinda de sul, durante o Permiano inferior. Esta interpretação vem, pelo menos em parte, de encontro ao afirmado por Ferreira (1982), com a diferença que o arco de Ponta Grossa seria "uma barreira parcial" ao avanço da transgressão marinha e não um "alto estrutural" que barrasse totalmente o mar neopaleozóico presente na Bacia do Paraná. Para Santos (1987), a sedimentação durante o intervalo bioestratigráfico I (Fig. $\mathrm{V}-5 \mathrm{C}$ ) foi de natureza predominantemente subaquática em grande parte da Bacia do Paraná, sendo a região interna da bacia coberta por um mar epicontinental, que representa o evento transgressivo iniciado durante a deposição do intervalo $\mathrm{G}$ e ampliado durante $\circ \mathrm{H}$. Durante o intervalo $\mathrm{I}_{2-4}$ (Figs. V-5D e V-6) o processo de deglaciação iniciado no intervalo $l_{1}$ se acentua e expande geograficamente. 


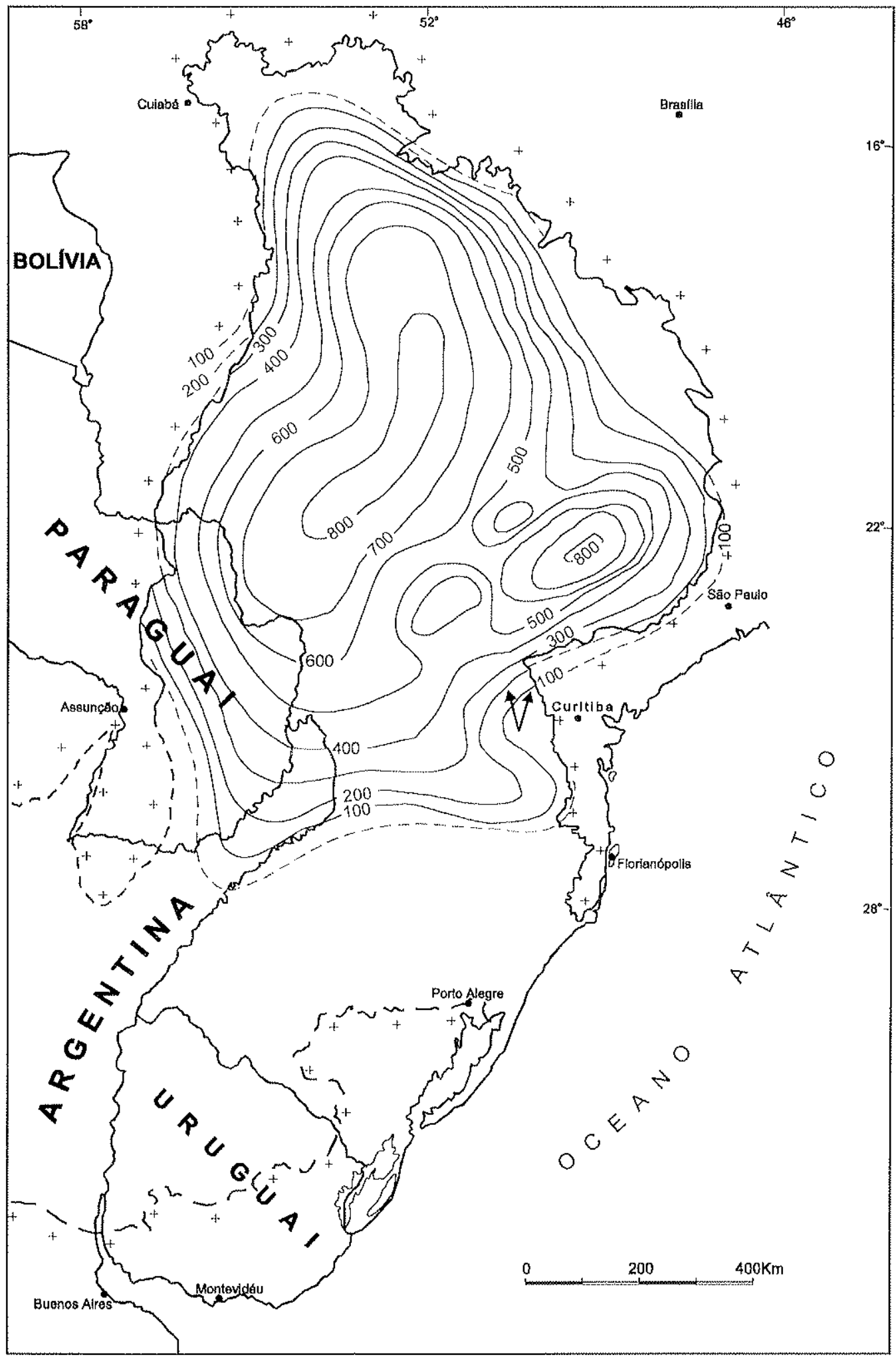

Figura V-4: Isoespessura do Itararé inferior (Fulfaro et al., 1980). Setas indicam sentido de movimento do gelo na área. 

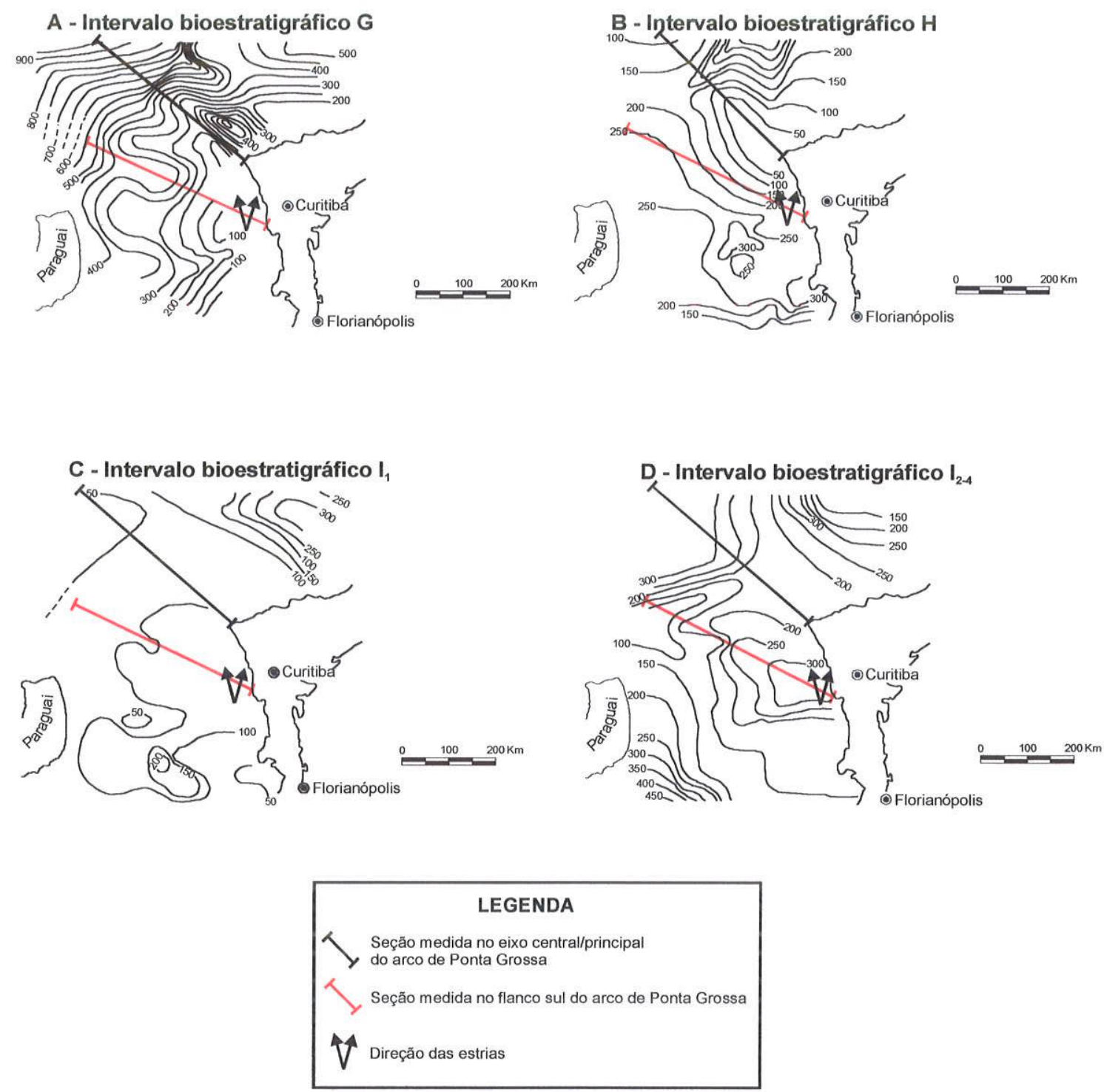

Figura V-5: Isoespessuras dos intervalos bioestratigráficos do Subgrupo Itararé (Santos, 1987). Linhas indicam localização das seções medidas no eixo e flanco sul do arco de Ponta Grossa (Curvas de variação de espessura da Fig. V-7).

Recente análise da história da subsidência da Bacia do Paraná apresentada por Quintas et al. (1999), através de técnicas de backstripping e modelagem termo-mecânica, levou ao reconhecimento de três descontinuidades significativas nas curvas de subsidência da Bacia do Paraná, que sugerem 3 (três) eventos distensivos.

O primeiro evento ocorreu há aproximadamente $440 \mathrm{Ma}$., que pode ter sido responsável pela deposição das seqüências siluriana e devoniana; o segundo teve inicio dentro do intervalo da discordância Neodevoniana/Eocarbonífera, cessando por volta de 296 Ma. com o início da sedimentação do Subgrupo Itararé, sendo, provavelmente, 
responsável pela deposição das seqüências permo-carbonífera, triássica e eventualmente jurássica; e o terceiro evento, associado a Formação Serra Geral, aproximadamente há 144 Ma., é responsável pela deposição da seqüência vulcânica juro-cretácea.

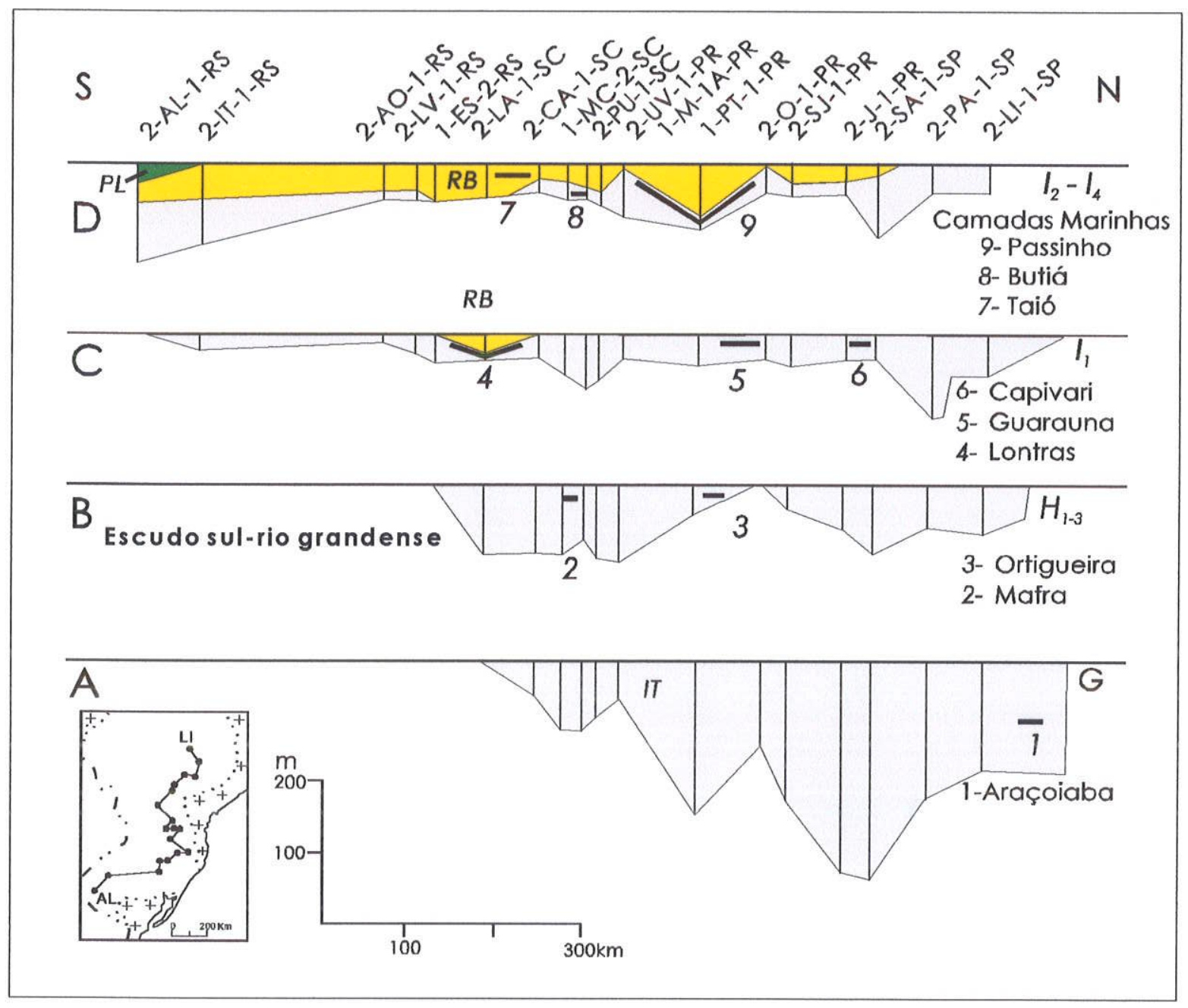

Figura V-6: Seções cronoestratigráficas do Subgrupo Itararé referentes aos intervalos bioestratigráficos $G, H_{1-3}, I_{1}$ e $I_{2-4}$ de Daemon e Quadros (1970). Notar a ausência de sedimentos no intervalo $\mathrm{H}_{1-3}$ no poço 2-O-1-PR, perfurado sobre o arco de Ponta Grossa e a gradual expansão da sedimentação em direção ao escudo sul-riograndense. IT: Subgrupo Itararé; RB: Formação Rio Bonito; PL: Formação Palermo (Modificado de Santos et al., 1996).

Segundo Quintas et al. (1999), nos mapas de isoespessura das formações sedimentares (Zalán et al., 1990 e 1991) percebe-se que as curvas de sedimentação são interrompidas nas vizinhanças do arco de Ponta Grossa, sugerindo que essas formações foram depositadas normalmente e, com o soerguimento do arco, sofreram erosão. Esta 
interpretação, assim como a de Ferreira (1982), está grandemente simplificada, pois leva em consideração apenas os dados obtidos a partir dos mapas de isoespessura total do Subgrupo Itararé. Uma rápida análise nos mapas de isoespessura dos intervalos bioestratigráficos de Daemon e Quadros (1970) e Santos (1987), como já comentado acima, revela uma história tectônica bastante complexa, rica e de resultados deposicionais os mais variados.

Quintas et al. (1999), calcularam as taxas médias de subsidência total e tectônica observadas para o Subgrupo Itararé, aproximadamente 26 e $14 \mathrm{~m} / \mathrm{Ma}$., respectivamente. Segundo os autores, no Devoniano, com o início de um processo convergente estabelecido pela subducção de uma placa juvenil sob a placa mais velha, há o desenvolvimento do arco de Assunção e a restrição do mar devoniano. A convergência culmina com o fechamento do proto-Pacífico e, consequentemente, o soerguimento da região atualmente ocupada pela Bacia do Paraná e o desenvolvimento do hiato do Carbonífero Inferior (Zalán et al., 1990).

Com o resfriamento da zona de colisão, dá-se inicio a primeira deposição continental da seqüência permocarbonifera. As sedimentações marinhas subseqüentes (Subgrupo Itararé e outras), marcam a reativação da zona de subducção, criando, possivelmente, na Bacia do Paraná, um ambiente de distensão retro-arco, dominado por falhas normais e subsidência.

Contudo, este tipo de interpretação, quanto ao ambiente tectônico reinante em uma bacia intracratônica como a do Paraná, deve ser considerada com cautela, principalmente quando consideramos a extensão da Bacia do Paraná e sua distância em relação a zona de subducção.

\section{V.1.1 - Dados adicionais}

Para uma compreensão mais clara do comportamento tectônico do arco de Ponta Grossa, durante a sedimentação do Subgrupo Itararé, foram construidas seções mostrando a variação de espessura do Subgrupo Itararé, semelhantes as referidas no início deste capitulo, sendo uma no eixo do arco de Ponta Grossa e outra em seu flanco sul, para cada intervalo bioestratigráfico estudado por Santos (1987). (Fig. V-7.)

Como já comentado, o eixo do arco de Ponta Grossa e seu flanco sul, tiveram comportamento tectônico distinto durante o Permo-Carbonífero. No intervalo bioestratigráfico $G$, o eixo central sofre subsidência mais acentuada que sua porção sul, onde estaria localizado um dos três lobos glaciais identificados por Santos (1987). 
No intervalo H observa-se a inversão tectônica na região, o flanco sul tornando-se subsidente e o eixo do arco de Ponta Grossa constituindo um alto estrutural onde não ocorreu deposição, mas erosão. No intervalo $l_{\uparrow}$ nova mudança ocorre no quadro paleogeográfico, o eixo central tornando-se subsidente e o flanco sul, apesar de ainda subsidente, apresenta maior estabilidade. $O$ intervalo $I_{2-4}$ mostra mais uma mudança na paleogeografia da área, o eixo central volta a elevar-se e, provavelmente, contribui para os depósitos flúvio-deltaicos da Formação Rio Bonito, enquanto que o flanco sul do arco apresenta uma acentuada taxa de subsidência.

Duas curvas de subsidência (Fig. V-8) elaboradas a partir dos poços 2-O-1-PR e 2-CS-1-PR, localizados na região central do arco de Ponta Grossa e em seu flanco sul, respectivamente, mostram, assim como as curvas médias da Figura $V-7$, comportamentos diferentes entre o eixo central do arco e seu flanco sul.

Como pôde ser observado pelos dados acima enumerados, a tectônica préMesozóica da região atualmente ocupada pelo arco de Ponta Grossa encerra grandes controvérsias e até incoerências entre os diversos autores apontados. Entrementes, algumas conclusões e hipóteses podem ser emitidas:

i) a região ocupada atualmente pelo arco de Ponta Grossa tem uma história tectônica pré-Mesozóica de grande importância na configuração da Bacia do Paraná, fato este já descrito por outros autores;

ii) o arco de Ponta Grossa, no neopaleozóico, alternou épocas de subsidência e elevação (Santos, 1987; Eyles et al., 1993);

iii) a região central e o flanco sul do arco de Ponta Grossa tiveram comportamentos diferentes no tempo geológico, decorrentes de diversos alinhamentos estruturais de direção NW, que compõem o arco de Ponta Grossa;

iv) a análise executada revela a possível existência de áreas emersas durante parte da sedimentação do Subgrupo Itararé (intervalos $\mathrm{G}$ e H);

v) a ocorrência maciça de superfícies estriadas no flanco sul do arco, está relacionada ao processo de subsidência imposto após o intervalo bioestratigráfico $H$ para esta região do arco, preservando as estruturas ali formadas, provavelmente, durante o intervalo $\mathrm{G}$ e, no mais tardar, no início do $\mathrm{H}$; e

vi) o paleodeclive da região, de maneira geral, foi sempre de sul para norte, corroborando com as indicações de paleofluxo do lobo Paraná. 

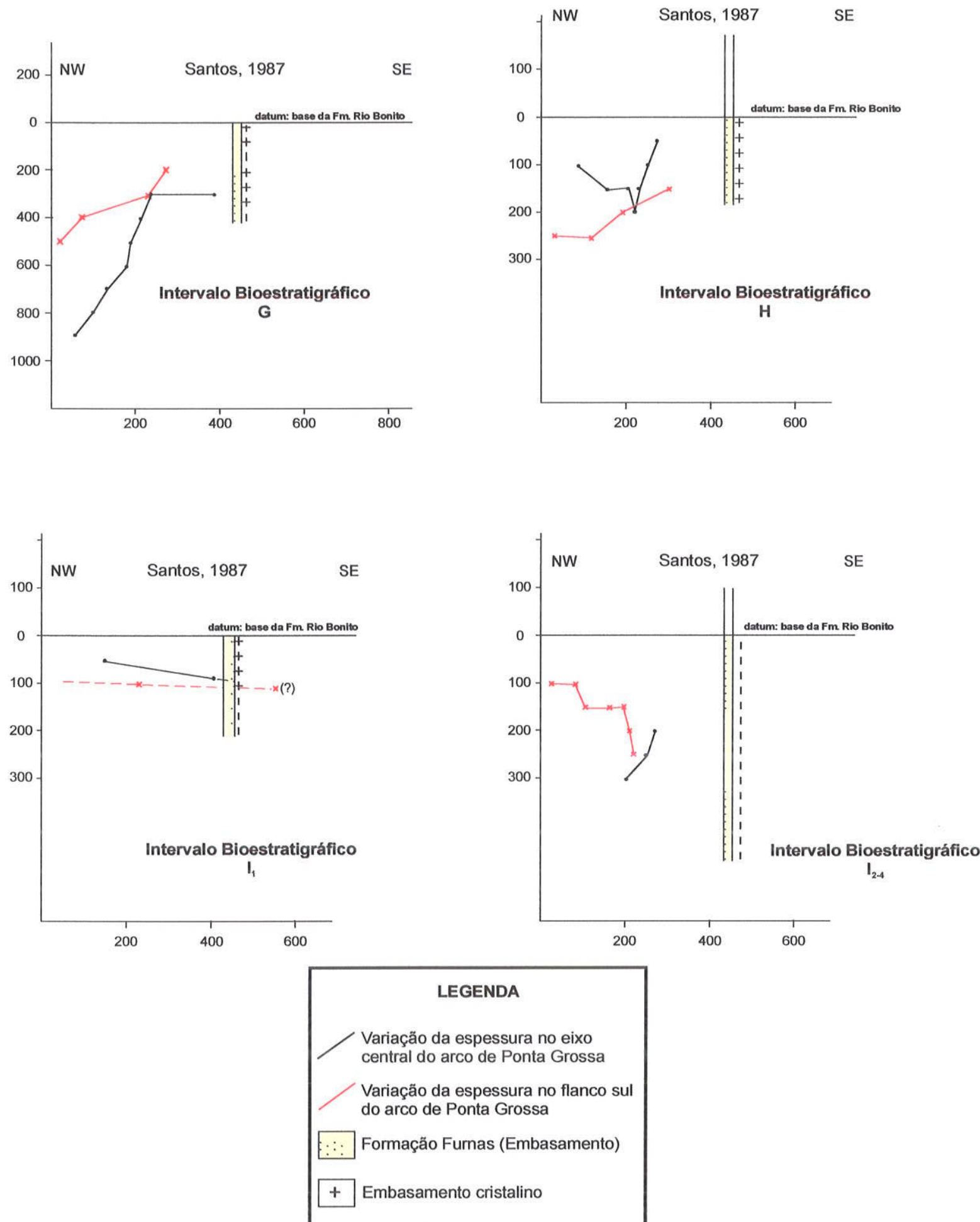

Figura V-7: Curvas médias do eixo central e flanco sul do arco de Ponta Grossa dos intervalos bioestratigráficos $\mathrm{G}, \mathrm{H}, \mathrm{I}_{1}$ e $\mathrm{I}_{2-4}$. Dados extraídos de Santos (1987). 


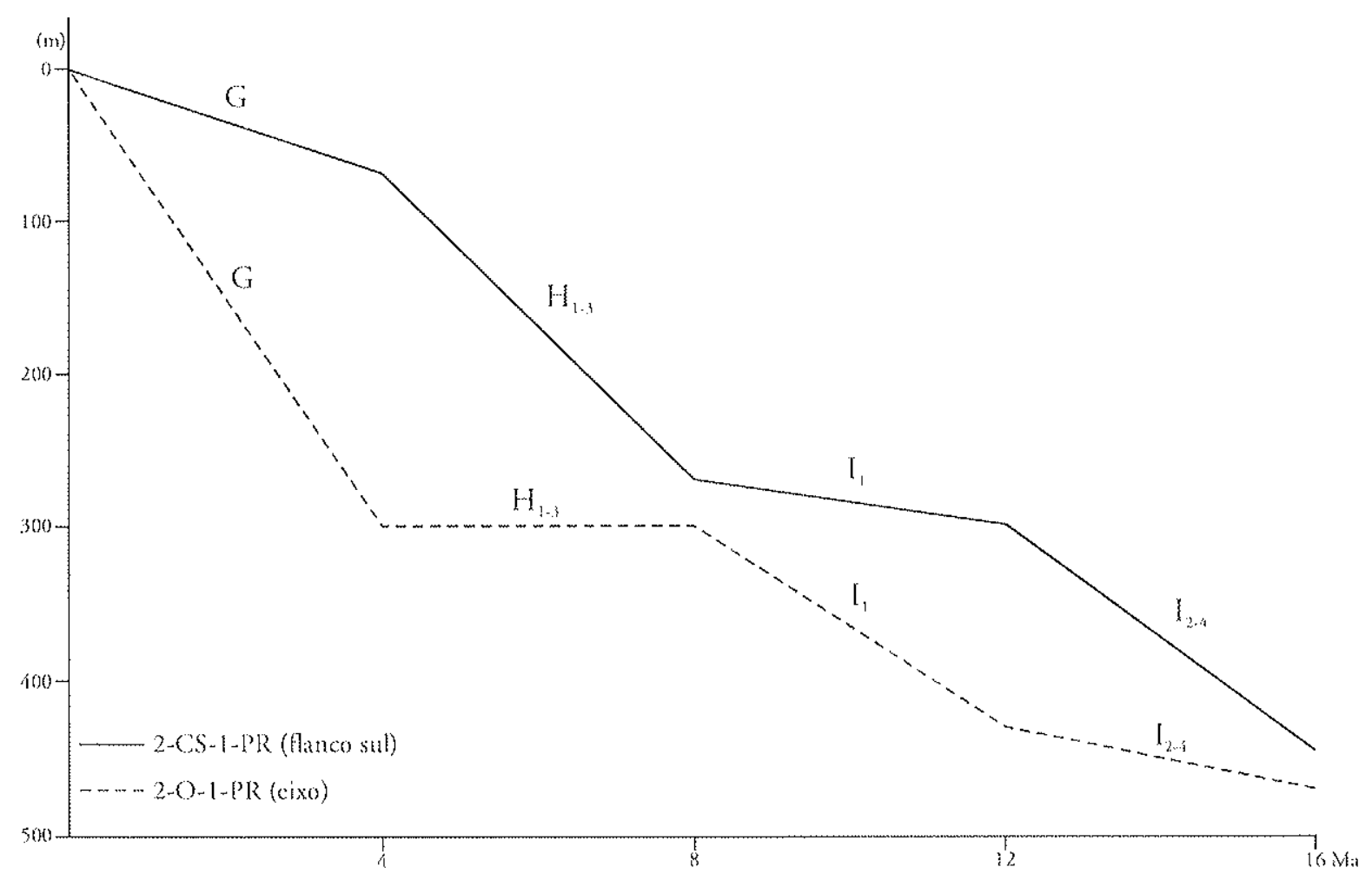

Figura V-8: Curva de subsidência do Subgrupo Itararé, nos poços 2-CS-1-PR (flanco sul do arco de Ponta Grossa) e 2-O-1-PR (eixo do arco de Ponta Grossa).

\section{V.2 - Feições glaciais no contexto da evolução geológica do arco}

Em capítulos anteriores, os produtos e processos de erosão e deposição ocorrentes na região em estudo foram analisados e interpretados com vistas à reconstituição das condições glaciais em que as feições se formaram, através da ação do lobo Paraná.

Conforme vimos, a assembléia de formas de terreno erosivas (pavimentos e superficies estriadas) e deposicionais (tills, morainas) configuram uma paisagem glaciada (glacial landscape, Bennett e Glasser, 1996), exumada e amplamente exposta no flanco sul do arco de Ponta Grossa. A distribuição das diferentes formas de terreno são, como discutido, controladas pela geleira, tanto espacial quanto temporalmente, por variáveis, tais como: velocidade, espessura, regime térmico, balanço de massa, além da geologia e topografia do substrato subglacial.

Diferentemente das descritas do Pleistoceno ou atualmente existentes nas altas latitudes ou altitudes, formas de terreno erosivas e deposicionais glaciais no registro prépleistocênico estão preservadas em bacias sedimentares. Desse modo, estão elas sujeitas à subsidência e cobertura por depósitos mais jovens, que podem incluir camadas marinhas formadas durante fases transgressivas pós-glaciais. 
A caracterização da área de estudo como uma paisagem glaciada neopaleozóica suscita, portanto, três questões de enorme interesse relacionadas ao seu contexto geológico, em particular no quadro da história tectono-sedimentar do arco de Ponta Grossa, a saber:

i) a natureza da superfície pré-glacial;

ii) a preservação geológica da paisagem glacial; e

iii) os processos geológicos relacionados à exumação e exposição atual da superfície.

Estes aspectos serão abaixo discutidos brevemente, com base em dados coletados em campo e os da literatura disponiveis.

\section{V.2.1 - Natureza da superficie pré-glacial}

A instalação das geleiras da glaciação neopaleozóica que afetaram a Bacia do Paraná foi precedida por um longo intervalo erosivo, abrangendo do final do Devoniano até o Carbonífero inferior. Esse extenso e intenso período de denudação e "peneplanização", com cerca de $60 \mathrm{Ma}$. de duração, sucedeu a elevação epirogênica pós-devoniana de toda a plataforma brasileira (Milani, 1997; Zalán et al., 1991). Corresponde a superfície erosiva, geologicamente, à discordância regional que (hoje) separa as megasequências ou ciclos transgressivos regressivos eopaleozóico e neopaleozóico da Bacia do Paraná (Zalán et al., 1991; Milani, 1997).

No interior e na margem leste da Bacia do Paraná, a superfície de discordância ou "peneplano" trunca uma variedade de terrenos pré-cambrianos, eopaleozóicos e meso e neodevonianos, profundamente arrasados, conforme evidencia o grau de metamorfismo de rochas que aí ocorrem (Santos, 1987). Corrobora esta interpretação a composição dos minerais pesados de arenitos do Subgrupo ltararé, estudados por Wu (1989), indicativos de proveniência de rochas de facies metamórfica de médio a alto grau ocorrentes na margem leste da Bacia do Paraná.

Inexistem dados adequados para caracterizar topograficamente a superfície erosiva pré-ltararé. A variedade de litologias afetadas pelo processo erosivo é compativel, entretanto, com a existência de significativas irregularidades do terreno e relevo moderado. Igualmente insegura é a estimativa da pendente regional. Uma indicação indireta da inclinação da superfície deriva de mapas de superfície de tendência de espessuras do Subgrupo Itararé (Fulfaro, 1971), que sugerem um paleodeclive da ordem de $1^{\circ}$ ou menor. 
As geleiras que atingiram a Bacia do Paraná no neopaleozóico, a partir de um centro glacial situado no sudoeste africano (Santos et al., 1996; Eyles, 1993; Frakes e Crowell, 1972; Crowell, 1999), movimentaram-se, portanto, sobre uma superfície grandemente aplainada, porém geologicamente heterogênea.

Crowell (1999) chama a atenção para o fato de uma bacia sedimentar afastada do interior continental, onde uma calota/manto de gelo está se formando, provavelmente, não dispõe do registro sedimentar inicial e final da glaciação. No quadro desse modelo evolutivo, os primeiros sedimentos a atingirem a área subsidente seriam, provavelmente, de natureza flúvio-glacial e desprovidos de qualquer evidência da ação da geleira. As caracteristicas do pacote sedimentar basal do Subgrupo Itararé, correspondente ao intervalo bioestratigráfico $\mathrm{G}$ da Bacia do Paraná, interpretado como de origem continental (Daemon e Quadros, 1970; Santos, 1987; Santos et al., 1996) pode ser compativel com o modelo de Crowell (1999). Este fenômeno pode também, pelo menos em parte, explicar o retardo no inicio do registro da glaciação na Bacia do Paraná, em comparação com as bacias glaciadas neopaleozóicas dos Andes (Eyles, 1993). Este autor sugere a subsidência tardia da bacia, que permitiu a acomodação e preservação dos depósitos sedimentares glaciais, que ter-se-ia iniciado somente quando esforços tectônicos gerados na margem ocidental ativa da América do Sul transmitiram-se intracontinentalmente, reativando estruturas do embasamento e levando à subsidência da área da bacia (Oliveira, 1989; Eyles, 1993).

Ainda no contexto das idéias acima, é possivel que a superficie de discordância pré-Itararé tenha sofrido extensa ação erosiva glácio-fluvial, antes de ser atingida pela margem lobada do manto de gelo de Windhoek (Santos et al., 1996). Embora o registro sedimentar subaéreo dessa fase possa ter sido posteriormente destruido por erosão subseqüente, parte dele, possivelmente, passou a se acumular na Bacia do Paraná, durante fase de subsidência acelerada ocorrida no neopaleozóico (Oliveira, 1989; Eyles et al., 1993).

Conforme já discutido, a discordância erosiva pré-ltararé, na área de estudo, desenvolve-se sobre arenito da Formação Furnas. O lobo glacial Paraná que afetou o arco de Ponta Grossa deslocou-se, pois, sobre um assoalho consolidado, litologicamente homogêneo, formado por arenito de acamamento em disposição horizontal, remodelando-o. Embora essencialmente plana, em âmbito regional, a superficie poderia conter zonas de fraqueza, provavelmente controladas por fraturas/falhas, ao longo das quais a erosão glacial incidiu mais intensamente. Esses locais ou "vales pré-glaciais" contém hoje espessuras significativas de rochas do Subgrupo ltararé, como é o caso da área da Colônia Witmarsum e de São Luís de Purunã. 


\section{V.2.2 - Preservação geológica da paisagem glacial}

Questões relacionadas a preservação geológica contemporânea à gênese das formas de terreno já foram suficientemente discutidas no Capítulo III. Nesta seção focaremos aspectos relacionados à evolução tectono-sedimentar da porção sul do arco de Ponta Grossa e a preservação dessas estruturas. Outros aspectos relacionados aos ciclos deposicionais (transgressão - regressão) registrados na seqüência sedimentar permo-carbonifera, também serão avaliados.

Tendo por base as informações disponiveis na seção V.1 (Evolução tectonosedimentar do arco de Ponta Grossa), algumas considerações a respeito da influência da evolução tectônica da região na preservação da paisagem glacial podem ser feitas.

A porção sul do arco de Ponta Grossa, durante o intervalo bioestratigráfico $G$, corresponde a uma região relativamente elevada, de baixa taxa de subsidência, enquanto o eixo da estrutura mostra significativa subsidência (Figs. V-7 e V-8). Neste contexto inicial da deposição do Subgrupo Itararé na área, há o condicionamento do fluxo glacial de sul para norte.

Nos intervalos bioestratigráficos seguintes $\left(\mathrm{H}, \mathrm{l}_{1}, \mathrm{l}_{2-3}\right)$, principalmente no intervalo $\mathrm{H}$, o flanco sul do arco de Ponta Grossa é submetido a um intenso e contínuo processo de subsidência, que acarretou um rápido avanço marinho sobre a região (transgressão marinha). Sendo assim, espesso pacote de sedimentos glácio-marinhos é depositado sobre a superfície glaciada, que desta forma e através da própria diagênese da bacia, ajudou a preservar a paisagem glacial.

\section{Ciclos deposicionais e estratigráficos}

Um dos objetivos que nortearam a presente dissertação, foi o de apresentar as várias questões aqui abordadas em um amplo espectro de escalas de trabalho (regionais e de detalhe), visando fornecer o quadro mais completo possivel da glaciação Gondvânica que atingiu a área sul do arco de Ponta Grossa. Tendo este principio em destaque, foi elaborada a Figura V-9, a qual tendo como base a coluna 1 , gentilmente cedida pelo Prof. Dr. J.R. Canuto, fez-se, tentativamente, correlações com as colunas 2 e 3 , que ilustram seções medidas na região da colônia de Witmarsum.

A coluna 1 mostra apenas 4 das 7 seqüências de $3^{a}$ ordem identificadas por Canuto (2001) e os diversos tratos de sistema associados. A coluna 2, onde há o empilhamento da sucessão exposta em Witmarsum, foi correlacionada à primeira e parte da segunda seqüência de $3^{\mathrm{a}}$ ordem descrita por Canuto op. cit., juntamente com alguns tratos de sistema, que estão assinalados na coluna 2 . 


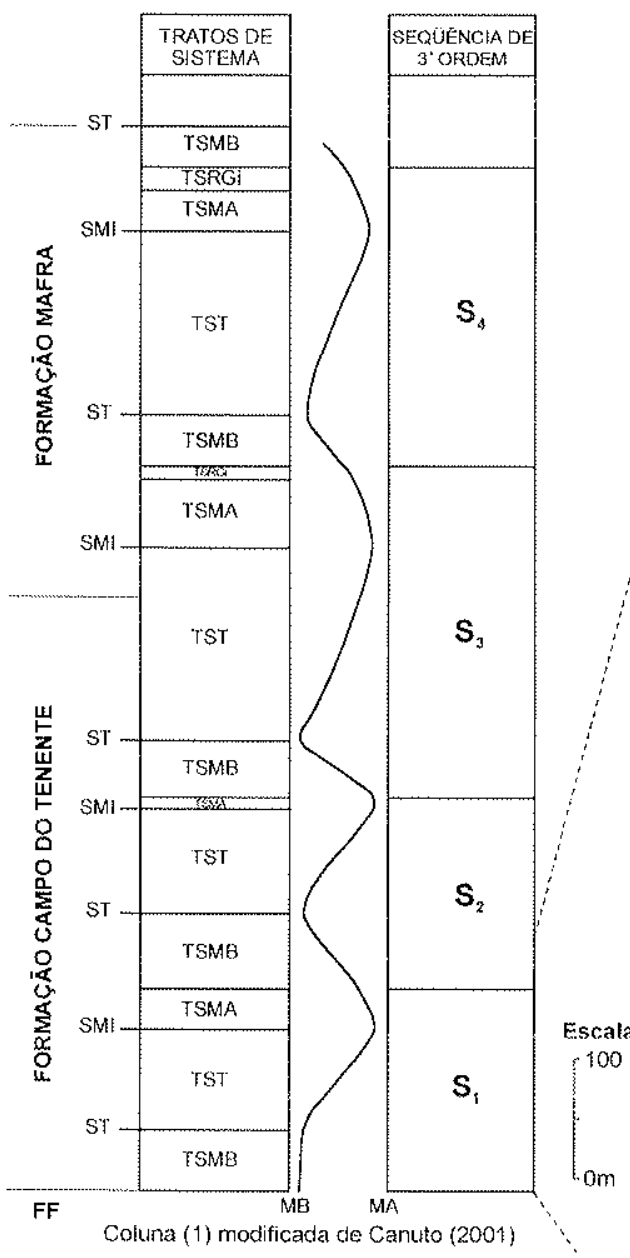

\section{LEGENDA}

FF - Formaçäo Furnas

ST - Superficie Transgressiva

SMI - Superfície de Máxima Inundação

TSMB - Trato de Sistema de Mar Baixo

TST - Trato de Sistema Transgressivo

TSMA - Trato de Sistema de Mar Alto

MB - Mar Baixo

MA - Mar Alto

\begin{tabular}{|c|c|}
\hline $\mathrm{A}^{\mathrm{A}}$ & Diamictito arenoso \\
\hline$\therefore$ & Diamictito silto-argiloso \\
\hline 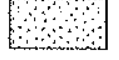 & Arenito fino \\
\hline$\therefore \because \div$ & Arenito médio \\
\hline & Arenito grosso \\
\hline 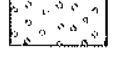 & Arenito con \\
\hline
\end{tabular}

-3>- Estratificaçăo cruzada acanatada

Estratificaçäo cruzada de baixo èngulo

佂 Suerficie erosiva

Figura V-9: Correlação dos ciclos estratigráficos do Subgrupo Itararé presentes na área. 
A seção inicia-se com um trato de sistema de mar baixo (TSMB), caracterizado, principalmente, pela presença de diversas superficies e depósitos erosivos (superficie estriada, tilito de alojamento, tilito de deformação etc.), apontadas na coluna 3 , que detalha os diamictitos expostos na coluna 2. Acima deste, ocorrem os tratos de sistema transgressivo (TST), caracterizado por areias de plataforma marinha rasa, e, talvez, o de mar alto (TSMA), visto que a superfície de máxima inundação (SMI) não está bem caracterizada nesta seção.

Subindo estratigraficamente, passa-se para a porção basal da $2^{a}$ seqüência de $3^{\text {a }}$ ordem identificada por Canuto (2001), caracterizada por sedimentos depositados em ambiente terrestre (lacustre, subglacial etc.) e estruturas relacionadas a clima periglacial (wedges de areia e composto).

Uma questão que surge do exame da Figura V-9 refere-se aos fatores que controlaram a deposição dos ciclos descritos e como eles se relacionam. As seqüências propostas por Canuto (2001) e suas características, estão provavelmente associadas a movimentações tectônicas do arco de Ponta Grossa no neopaleozóico, podendo elas estarem ligadas ou não à glácio-isostasia.

As colunas 2 e 3 , apesar de também estarem sujeitas aos movimentos tectônicos do arco, apresentam ciclos deposicionais de menor ordem. O principal controle desses ciclos foi, provavelmente, o próprio lobo Paraná. Os sucessivos episódios de avanço e recuo da geleira estão associados a variações da dinâmica glacial, produzindo condições propícias para o empilhamento de pacotes de diamictito e rochas associadas (Cap. IV).

Um exemplo disto é o desenvolvimento de condições climáticas periglaciais na região de Witmarsum (Cap. IV), que só foi possivel graças a retirada da geleira, pelo menos por um período, daquela região. A que distância se localizava a frente glacial não é possivel determinar pelos dados disponiveis, pois clima periglacial pode-se formar em áreas muito distantes e sem relação direta com frentes glaciais. Contudo, pela latitude em que se encontrava a Bacia do Paraná durante a glaciação Gondvânica, é possível se imaginar que a frente da geleira não se encontrava muito distante.

A inter-relação desses controles estratigráficos/deposicionais (movimentos tectônicos e dinâmica glacial) pode ser observada através das grandes transgressões marinhas que afetaram o flanco sul do arco de Ponta Grossa. Na área da Colônia Menonita de Witmarsum é representada pelos bancos de arenito de plataforma marinha rasa, e na seção de Palmeira pelos folhelhos com clastos caídos. A combinação de movimentos tectônicos negativos e o recuo da geleira propiciaram as condições necessárias para a rápida subida do nivel do mar e, consequentemente, a deposição e o empilhamento dessas faciologias. 


\section{V.2.3 - Exumação e exposição atual da superficie glaciada}

Uma das características que mais chamam a atenção na região estudada, é a enorme abrangência em área das formas de terreno analisadas, cerca de $1.500 \mathrm{~km}^{2}$, não existindo nenhum outro análogo pré-pleistocênico no mundo que se iguale ao exemplo brasileiro. Sendo assim, faz-se necessário explicar com se deu a exumação e exposição de uma área tão ampla.

Com certeza a exumação dessa superfície glaciada está intimamente relacionada à evolução tectônica do arco de Ponta Grossa, e mais especificamente ao arqueamento juro-cretácico da região. O arqueamento da área, associado ao extenso evento extrusivo Serra Geral, forneceu condições propícias para que ocorresse a exumação da superfície glaciada. A frente erosiva produzida após o arqueamento mesozóico chega a alcançar, em seu ponto de maior extensão, mais de $300 \mathrm{~km}$, biselando desde rochas do embasamento cristalino (arqueanas e proterozóicas) até de toda coluna paleozóica, inclusive rochas permo-carboniferas, onde se encontram os depósitos e formas de terreno estudadas nesta dissertação. 


\section{VI -CARACTERÍSTICAS DO LOBO GLACIAL PARANÁ}

A glaciação neopaleozóica no flanco sul do arco de Ponta Grossa tem sido associada à ação de um lobo glacial do manto de gelo de Windhoek, o lobo glacial Paraná (Frakes e Crowell, 1972; Santos et al., 1996). Essa massa de gelo foi postulada principalmente com base na orientação das estriações glaciais, cujo padrão é, nessa região, distinto do encontrado em outras partes da margem leste da Bacia do Paraná. As dificuldades do uso de estriações glaciais na reconstrução do fluxo de gelo regional já foram comentados anteriormente e serão tratadas com mais pormenores na discussão referente a paleogeografia neopaleozóica.

A grande quantidade de dados disponiveis na área de estudo, particularmente as referentes às formas de terreno subglaciais erosivas e deposicionais, oferecem também uma oportunidade de inferir alguns parâmetros glaciológicos do lobo Paraná. Alguns desses aspectos foram já abordados em conexão com as discussões sobre origem das formas de terreno. Nesta oportunidade, pretende-se integra-los, juntamente com novas observações e dados, no sentido de compor um quadro geral, embora preliminar, das características e do comportamento da massa de gelo que atuou nesta parte da Bacia do Paraná. O exercicio leva ainda em conta as reconstruções paleogeográficas da glaciação na Bacia do Paraná de outros autores (Frakes e Crowell, 1972; Santos, 1987; Santos et al., 1996).

As assembléias de formas de terreno glaciais erosivas e deposicionais ocorrentes na área (Cap. III), constituem informações básicas para a presente discussão. Outros aspectos importantes referem-se às relações estratigráficas entre estas assembléias e outros elementos documentados na região (Caps. IV e V). Dentro de um manto de gelo, diferentes assembléias de formas de terreno ocorrem em diferentes locais e, portanto, podem se superpor durante o avanço e recuo do gelo. O controle estratigráfico é, pois, necessário na interpretação de seqüências de sedimentos verticais, no contexto da lei de Walther.

Tendo em vista as considerações acima, algumas generalizações podem ser feitas a respeito do lobo Paraná:

a) com base na paleogeografia interpretada do manto de gelo de Windhoek (Santos et al.,1996), pode-se supor ter tido ele uma distribuição climática em que o centro da glaciação situar-se-ia em condições continentais, na África austral, enquanto a sua extremidade ocidental, junto à margem leste da Bacia do Paraná, experimentava condições marítimas. 
b) a margem lobada do manto de gelo, nestas condições, deveria ter um gradiente de balanço de massa elevado. Santos et al. (1996), por exemplo, propõem que os lobos glaciais neopaleozóicos ter-se-iam estabilizado em condições de geleiras de maré, em contato com o mar que cobria a Bacia do Paraná.

c) as assembléias de formas de terreno aqui discutidas (Cap. III) apontam consistentemente a existência de condições de base quente no lobo glacial Paraná, como também concluíram diversos autores (Santos, 1987; Santos et al., 1996; Eyles et al., 1993 e outros). A presença de água subglacial, associada a uma topografia aplainada, favoreceriam rápido deslizamento (sliding) de pequena espessura de geleira sobre as rochas do substrato. Tendo como base o modelo descrito por Hallet (1979), a geleira comportar-se-ia como uma "lixa" sobre o substrato, teria seu poder abrasivo proporcional à velocidade de fluxo.

d) a variação estratigráfica notada no tamanho de sulcos e estrias, como é o caso de Palmeira, pode indicar variação na intensidade erosiva. O paralelismo das feições lineares nos afloramentos estudados e a ausência de conjuntos de estrias de orientação distinta, entrecruzantes sugere sua formação, em cada caso, por evento erosivo único. A preservação das estruturas pode estar relacionada a recuo da geleira em condições de base fria (Bennett e Glasser, 1996; Benn e Evans, 1998). Contudo, as condições climáticas marítimas impostas por sua proximidade da margem leste da Bacia do Paraná, não corroboram esta hipótese.

e) a presença de superfícies múltiplas e suas características (Palmeira, São Luís de Purunã e Witmarsum) implica em alternância de fases de erosão planar e deposição. Esta situação pode resultar de variações do esforço de cisalhamento basal da geleira deslizando sobre substrato inconsolidado ("deformável") ou, talvez, alternância de períodos de fluxo rápido da geleira, associado a episódios de surge, acompanhado de erosão, e períodos de menor velocidade de fluxo, em que ocorreria deposição.

f) o lobo glacial Paraná apresentava, provavelmente, base relativamente plana, condicionada pelo relevo arrasado e peneplanizado que predominava na região. No caso de Palmeira, algumas pequenas protuberâncias na base da geleira seriam responsáveis pela formação de sulcos e estrias.

g) o substrato sobre o qual a geleira se movimentou inicialmente é reologicamente monótono, constituído por arenitos devonianos da Formação Furnas, de disposição horizontal, dificultando a geração de clastos e sua incorporação à base da geleira (arrancamento glacial), pois apresentavam poucas descontinuidades e zonas de fraqueza. Uma das evidências disso é o restrito número de clastos de arenito Devoniano nos diamictitos, mesmo nos basais. 
h) o provável limite do avanço da geleira seria o mar neopaleozóico, que na época ocupava o centro da Bacia do Paraná (Santos et al., 1996), pois o relevo não apresentava obstáculos para o avanço da massa de gelo. O lobo Paraná, em sua extremidade marinha, ter-se-ia comportado como uma geleira de maré e, em parte, aterrada na plataforma marinha. A geleira, provavelmente, não formou uma plataforma flutuante de gelo, pois a mesma não se encontrava em posição polar (Santos et al., 1996).

i) seguindo ainda o modelo de Hallet (1979), com a diminuição da velocidade de fluxo do lobo Paraná, haveria condições para a deposição das camadas de till subglacial, que formariam o substrato, juntamente com os sedimentos pró-glaciais (flúvio-glaciais e glácio-lacustres), do segundo avanço da geleira. 


\section{VII - PALEOGEOGRAFIA E HISTÓRIA GEOLÓGICA}

Vários elementos obtidos na presente pesquisa são relevantes para a reconstituição do quadro geral paleogeográfico dos depósitos glaciais e história glacial da parte sul do arco de Ponta Grossa.

Este incluem os seguintes dados:

- padrão de fluxo regional do lobo glacial Paraná;

- estratigrafia glacial da área;

- ambientes deposicionais documentados;

- arcabouço tectono-sedimentar da região.

Todos esses aspectos foram já tratados separadamente nos capitulos precedentes. Pretende-se agora tentar integra-los num quadro consistente.

\section{VII.1 - Fluxo glacial}

A interpretação do fluxo regional do lobo Paraná no flanco sul do arco de Ponta Grossa, constitui provavelmente o dado de Geologia Glacial mais importante para a reconstituição da paleogeografia glacial da área

Embora a orientaçăo das estriações glaciais sejam comumente usadas nesse sentido, a ampla literatura disponivel sobre o assunto (e.g., Embleton e King, 1975; Benett e Glasser, 1996), alerta sobre as dificuldades envolvidas nessa interpretação. Variações na orientação de estrias glaciais podem derivar de: a) fases glaciais distintas, relacionadas com diferentes centros glaciais; b) presença de irregularidades no embasamento; c) variação na drenagem, relacionada com a presença de divisores de gelo (ice devides); e d) mudanças na direção de fluxo durante fase de recuo glacial.

Esses problemas tornam às vezes difícil estabelecer uma estratigrafia glacial correta em que as estriações sejam claramente correlacionadas com os depósitos glaciais associados. O quadro estratigráfico interpretado para a região (Fig. VII-1), leva em conta essas questões.

A interpretação dessas ocorrências em termos de uma estratigrafia glacial, exige, portanto, um exame acurado das feições de caráter regional, já que estrias sobre o embasamento e depósitos subglaciais podem ser produzidos durante um único avanço.

O estudo realizado refere-se ao padrão de fluxo regional da geleira, referentes às superfícies de abrasão I e II, as mais amplamente representadas na área. 

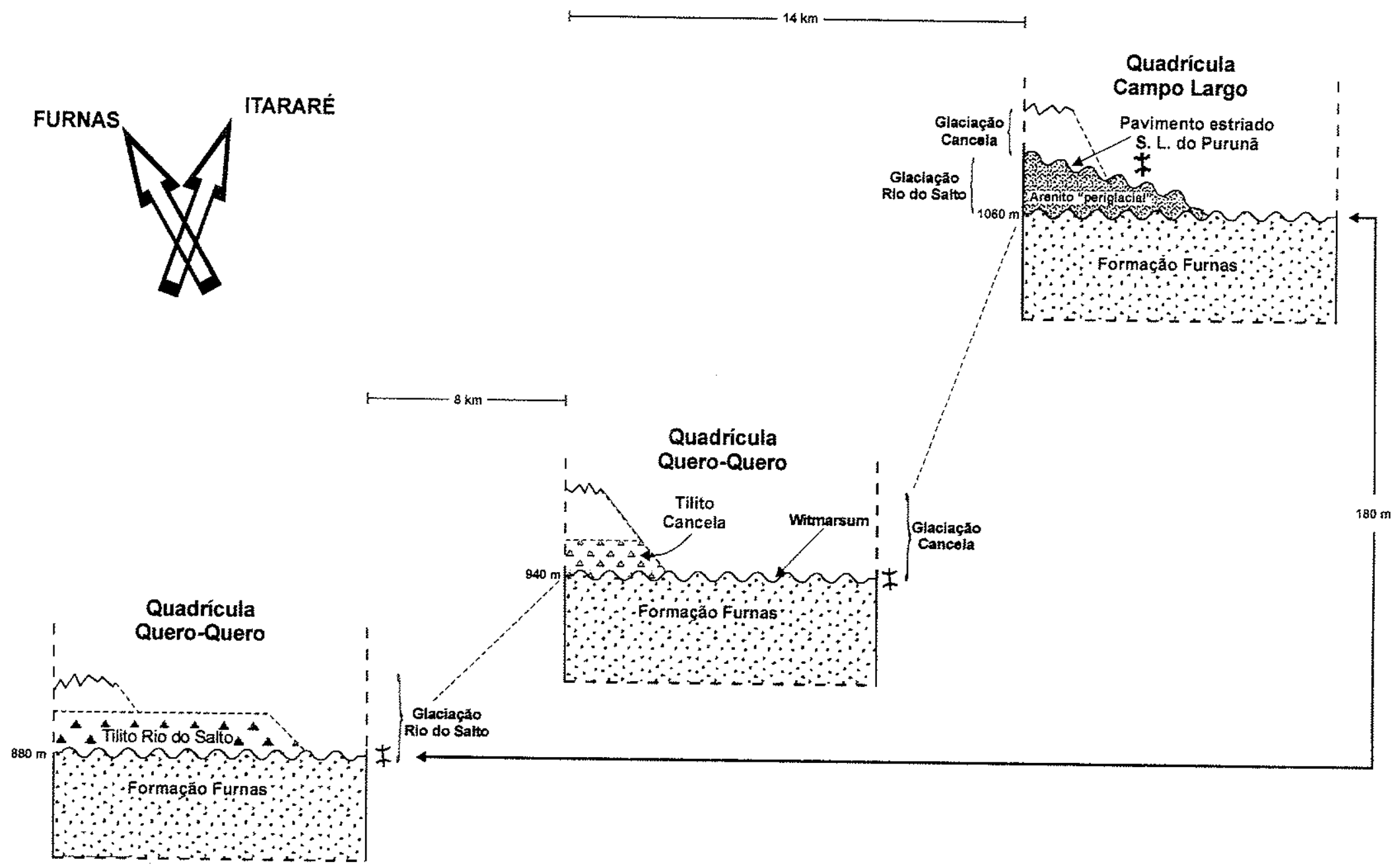

Figura VII-1: Interpretação da estratigrafia glacial da área segundo Bigarella et al., 1967; Fuck e Bigarella, 1967. Posição das seções obedece à cota topográfica atual. 
A fim de testar a possivel existência de padrões distintos de fluxo, sugerida pela simples observação da distribuição das estrias nos mapas disponiveis, os dados de direção coletados e os copilados da literatura foram tratados estatisticamente através do programa Quickplot. Inicialmente foram tratados todos os dados disponíveis em um único diagrama (Fig. VII-2), onde pode-se observar que as direções obtidas variam entre NWe NE (valor eigen 0,889). Evidencia-se também claramente a existência de duas concentrações distintas de valores.

Em uma segunda etapa, as direções obtidas sobre o arenito Devoniano da Formação Furnas foram tratadas separadamente das coletadas sobre os sedimentos do Subgrupo Itararé. Os resultados indicam que as estrias sobre os arenitos da Formação Furnas possuem direção predominante NW e as sobre sedimentos glaciogênicos do Subgrupo Itararé, direção NE (valores eigen, respectivamente, 0,955 e 0,938). (Fig. VII3B.)

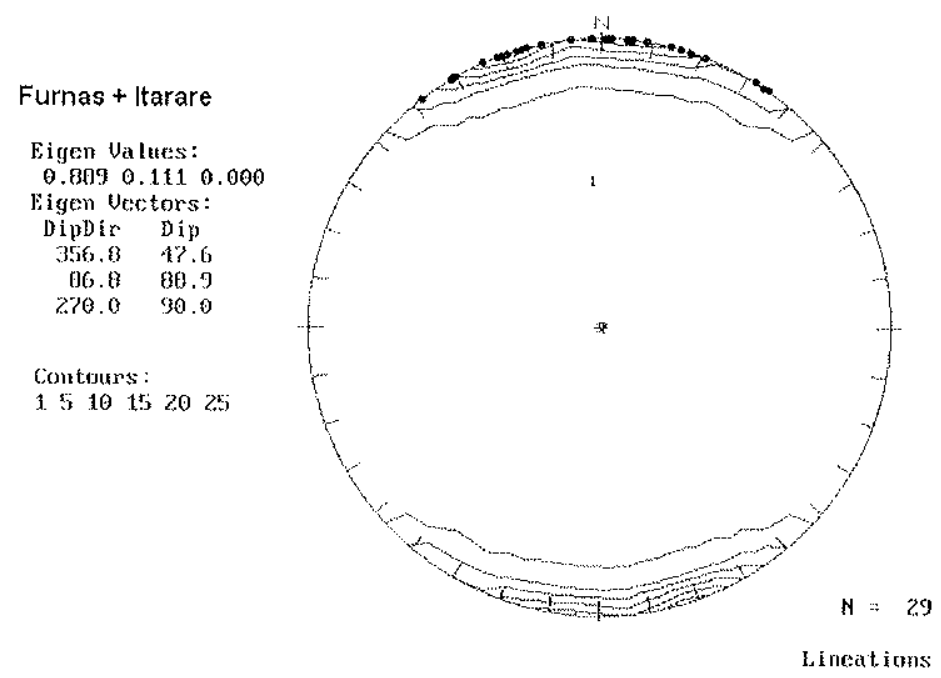

Figura VII-2: Direções das estrias sobre a Formação Furnas e o Subgrupo Itararé.

Com base nos dados obtidos, três hipótese de padrão de fluxo regional podem ser inicialmente elaboradas:

a) fluxo glacial único, inicialmente para NW, sobre o arenito Furnas, na parte sul da área, infletindo-se para NE, no norte desta, sobre o Subgrupo Itararé. O esquema implica em ocorrência de erosão e deposição subglacial extensa, durante um único evento de avanço da geleira, o que é altamente improvável; 

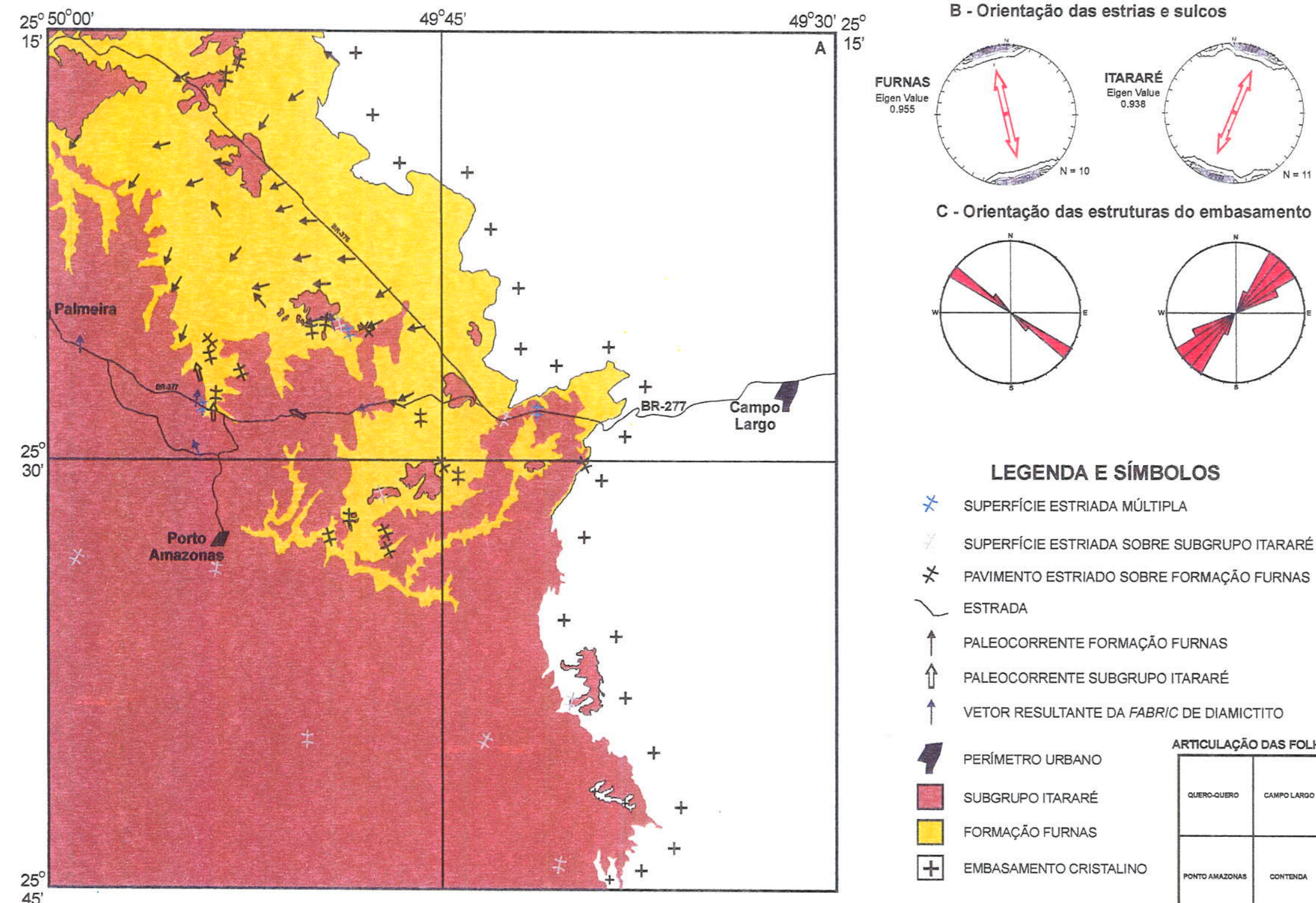

C - Orientação das estruturas do embasamento
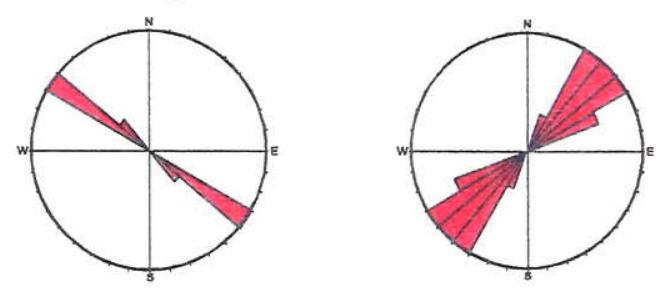

\section{LEGENDA E SÍMBOLOS}

* Superficie estriada múltipla

SUPERFICIE ESTRIADA SOBRE SUBGRUPO ITARARÉ

* PaVimento estriado sobre formaçāo furnas

乙 ESTRADA

$\uparrow$ PALEOCORRENTE FORMAÇÃO FURNAS

i PALEOCORRENTE SUBGRUPO ITARARÉ

$\uparrow$ VETOR RESULTANTE DA FABRIC DE DIAMICTITO

1 perimetro urbano

$\square$ SUBGRUPO ITARARÉ

$\square$ FORMAÇÃO FURNAS

t embasamento cristalino

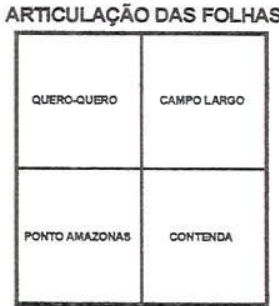


Figura VII-3: A. Mapa geológico compilado de Fuck et al., 1965; Muratori et al.,1965; Palka et al.,1966 e Trein et al., 1965, com acréscimos, mostrando direções de estrias, paleocorrentes (Furnas e Itararé) e fabric de clastos. B. Direção média das estrias sobre a Formação Furnas e Subgrupo Itararé. C. Orientação das estruturas do embasamento. Notar que estruturas do embasamento podem ter condicionado o fluxo da geleira pela área.

b) os dois padrões de fluxo glacial corresponderiam, respectivamente, às "glaciações" Rio do Salto e Cancela, propostos por Bigarella et al. (1967) e Fuck e Bigarella (1967). Esta hipótese é contrariada pela não constatação de dois conjuntos entrecruzantes de estriações sobre as mesmas superficies de rochas sedimentares do Subgrupo Itararé (depósitos "periglaciais" e tilito Rio do Salto);

c) finalmente, uma terceira hipótese, considera a ocorrência de dois eventos de erosão subglacial ligadas a dois episódios de avanço distintos, o primeiro estriando o arenito Furnas e o segundo depósitos glaciais do primeiro avanço, expostos após deglaciação.

A terceira hipótese é no momento considerada a mais provável do ponto de vista dos modelos disponiveis de erosão e deposição subglacial. Segundo Hallet (1979), por exemplo, para que ocorra erosão, a geleira necessita estar em contato contínuo com o assoalho glacial. Como já acima comentado, deposição e erosão subglacial são processos, no geral, mutuamente exclusivos. Deposição concomitante à erosão pode, contudo, ocorrer em pequenas depressões do embasamento (e.g., till de alojamento) sobre estruturas do tipo rocha moutonneé e, portanto, de limitada distribuição espacial.

É preciso notar que o esquema acima discutido é aplicável somente ao pavimento e superfície estriada da parte basal do Subgrupo Itararé. Conforme se vê na Fig. VII-1, o fluxo do gelo pode ter variado substancialmente durante a deposição do resto do Subgrupo Itararé na área.

O sentido do movimento do lobo glacial Paraná para o $N$, aceito na literatura, apoia-se no padrão geral de paleodrenagem glacial na margem leste da Bacia do Paraná (Rocha-Campos, 1967; Frakes e Crowell, 1969; Santos et al., 1996). Essa orientação é consistente com o padrão de paleodrenagem de arenitos do Subgrupo Itararé e fabric de diamictitos, no geral para NW, na área, registrados na literatura (Fuck e Bigarella, 1967). O mesmo sentido é obtido das estruturas tipo cristas de till (flutes) observadas na superfície estriada de São Luís de Purunã (Cap. III).

Uma questão ainda não inteiramente resolvida refere-se aos fatores que teriam controlado a mudança de padrão de fluxo do gelo no sul do arco de Ponta Grossa. Uma resposta conclusiva sobre essa questão não pode atualmente ser concebida. Contudo, 
lineamentos de direção NW, presentes tanto no embasamento, quanto na Bacia do Paraná, durante os primeiros estágios da glaciação neopaleozóica, poderiam produzir zonas de fraqueza mais acentuadas, por onde a geleira teria fluido (Fig. VII-3C). Posteriormente, os lineamentos de direção NE tornaram-se mais ativos, condicionando o fluxo da geleira nesta direção, ou a topografia produzida pelo primeiro avanço glacial formou estruturas e feições morfológicas que direcionaram o fluxo do gelo.

\section{VII.2 - Estratigrafia da área}

As seções estratigráficas medidas na área de Witmarsum são as mais espessas e complexas observadas na área de estudo. Ocorrem elas isoladamente da faixa de afloramento principal do Subgrupo Itararé, na Bacia do Paraná. Seu estudo detalhado permitiu elaborar uma coluna estratigráfica geral da sucessão glacial, com cerca de 114 $m$ de espessura, que serve de referência para toda a área de estudo.

Como vimos (Cap. IV), a sucessão demonstra a alternância entre diamictitos depositados em condições terrestres, intercalados com sedimentos marinhos rasos, recobrindo o pavimento e superfície de erosão glacial da base do Subgrupo Itararé.

Outros afloramentos estudados, particularmente as superficies estriadas de Palmeira e São Luís de Purunã, distribuem-se também descontinuamente, o que torna a sua correlação com a seção de Witmarsum algo problemática.

O esquema de correlação geral estratigráfica dos afloramentos do Subgrupo Itararé estudados no flanco sul do arco de Ponta Grossa é mostrado na Figura VII-4. O esquema leva em conta a composição litológica e as facies dos sedimentos, a estratigrafia local, relações estratigráficas com a Formação Furnas e com superfícies estriadas intraformacionais no Subgrupo Itararé.

Com base nesses elementos, sete episódios de avanço glacial podem ser reconhecidos no Subgrupo Itararé (I-VII, Fig. VII-4). Trata-se, contudo, de um número mínimo, dada a limitação de afloramentos em algumas partes da seção, que impediu o seu detalhamento estratigráfico.

I e II são os dois eventos glaciais iniciais da área e estão documentados pelo pavimento estriado formado sobre o arenito Furnas e superficies estriadas sobre rochas sedimentares do Subgrupo Itararé, respectivamente.

Bigarella et al. (1967) e Fuck e Bigarella (1967) interpretaram dois eventos glaciais, a "Glaciação Rio do Salto" e a "Glaciação Cancela" no Subgrupo Itararé da região estudada. Ao primeiro corresponderia o avanço glacial que truncou a Formação Furnas, formando o pavimento, hoje descontinuamente exposto no vale do rio do Salto, depositando sobre ele o "Tilito Rio do Salto", o mais antigo da área. O recuo do gelo, por 
sua vez, levou à deposição de arenitos interpretados como "periglaciais". O avanço glacial seguinte ("Glaciação Cancela") teria erodido e estriado tanto a Formação Furnas, quanto arenitos "periglaciais" da "Glaciação Rio do Salto", superposta. Adicionalmente, a geleira teria depositado o "Tilito Cancela", que ocorre sobre o pavimento estriado de Witmarsum (Fig. VII-4)

Embora atraentes, o esquema acima encerra algumas dificuldades, a saber:

- conforme já discutido, estriações com as duas orientações não foram encontradas na superfície estriada formada sobre depósitos do Subgrupo Itararé. Ao contrário, os afloramentos indicam estriação gerada durante um único episódio erosivo em cada caso;

- a despeito de sua grande amplitude, a atribuição dos pavimentos a episódios de avanço glacial, é ainda incerta e depende de controle estratigráfico e geocronológico mais acurado;

- adicionalmente, o uso dos termos "glaciação" e "periglacial" estão incorretos, no caso em questão é mais apropriado o uso de "avanço" e "sedimentos proglaciais", respectivamente.

Ainda em caráter preliminar, a Fig. VII-1 exibe a proposta de correlação entre as duas superfícies de abrasão I e II e as que ocorrem nas outras seções estratigráficas levantadas.

As superfícies de abrasão glacial III - VII identificadas por estriações e contatos erosivos entre corpos de diamictito tem valor local, embora possam também representar episódios de erosão extensos. A amplitude do evento glacial correspondente pode, pois, ser variável.

$\mathrm{Na}$ seção de Witmarsum, algumas sucessões de diamictitos podem refletir eventos de oscilações menores da margem glacial em recuo, o que se coadunaria com a ocorrência das morainas de empurrão sazonais (Cap. IV); enquanto que outros niveis de erosão associados as feições periglaciais envolveriam episódios de mudança climática mais intensa. Oscilações da margem glacial em recuo podem também ser responsáveis pela reiteração dos eventos erosivos demonstrado pelas superfícies estriadas múltiplas.

Episódios de recuo glacial mais intensos e duradouros, acompanhado de trangressões marinhas pós-glaciais, estariam também documentadas pela intercalação de camadas de arenito marinho na seção de Witmarsum.

Em resumo, portanto, é evidente que a sucessão glacial estudada envolve diferentes ciclos estratigráficos ou deposicionais de diferentes escalas de tempo e controlados por diferentes fatores auto e alocíclicos. 


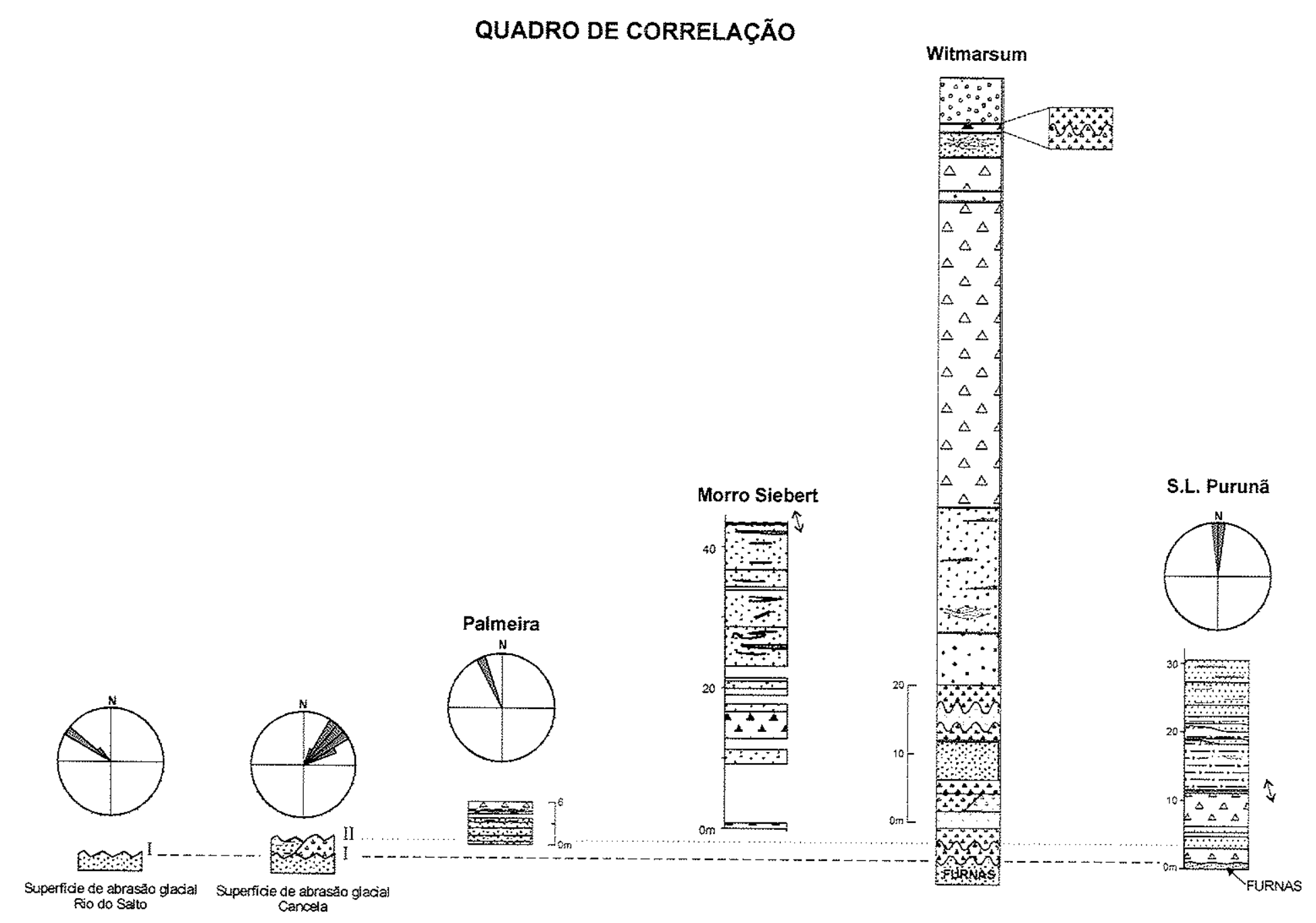

Figura VIl-4: Esquema provisório de correlação entre as seções de Palmeira, Witmarsum, Morro Siebert e São Luís de Purunã em relação aos dois episódios de fluxo glacial associados às direções das estrias. 
Já no âmbito da Bacia do Paraná, Canuto et al. (2001) propôs o reconhecimento no Subgrupo ltararé de sete seqüências estratigráficas de $3^{\text {a }}$ ordem. As seqüências representam sucessões granodescrescente/granocrecente ascente, de espessura variável, em média $100 \mathrm{~m}$.

Embora de forma precária, é possivel especular sobre a correlação de eventos registrados no afloramentos do flanco sul do arco de Ponta Grossa e os que ocorrem na parte principal da Bacia durante a deposição do Subgrupo Itararé. Assim, por exemplo:

a) as camadas marinhas que separam os pacotes de diamictitos na seção de Witmarsum são consideradas como equivalentes aos tratos de sistema de mar alto reconhecidos na estratigrafia de seqüências do Subgrupo Itararé (seqüências de $3^{a}$ ordem; Canuto, 2001; Canuto et al., 2001). Note-se que nem todas as facies internas na seção de Witmarsum e a de Canuto (2001) coincidem, em razão da variação lateral de facies entre uma seção glácio-proximal (terrestre) e distal (marinha);

b) a seqüência 1 de Canuto (2001) e Canuto et al. (2001), delimitada em sua base pela superfície de abrasão glacial Rio do Salto, pode ser correlacionada ao intervalo bioestratigráfico $\mathrm{G}-\mathrm{H}_{1}$, durante o qual, segundo Santos et al. (1996), ocorreu o episódio glacial mais intenso na área, corroborado pelos mapas de isoespessura dos intervalos $G$ e H (Cap. V). A seqüência II, que está parcialmente preservada na área de Witmarsum, não pode ser correlacionada a nenhum intervalo bioestratigráfico, tendo em vista a inexistência de controle cronoestratigráfico preciso. Sendo assim, apesar das seqüências identificadas por Canuto (2001) e Canuto et al. (2001) estarem teoricamente delimitadas por grandes avanços do lobo glacial Paraná, a superficie de abrasão glacial Cancela não pode ser seguramente correlacionada à superfície que delimita a seqüência I da II.

\section{VII.3 - História glacial}

O flanco sul do arco de Ponta Grossa caracterizava-se, em um primeiro instante, numa região extremamente plana (peneplanizada) e elevada a poucos metros acima do nível do mar. Neste contexto o lobo glacial Paraná, um ramo do manto de gelo de Windhoek, instala-se na regiáo e flui primeiramente de SSE para NNW, para o centro da bacia. Nestas condições o mar encontrava-se a oeste e noroeste da área estudada.

Dentro deste contexto ocorreriam flutuações da margem da geleira, controlada, principalmente, por mudanças da dinâmica glacial, que foram responsáveis pelo empilhamento das seqüências de diamictito (Cap. IV). Após este periodo inicial o lobo glacial Paraná começa a apresentar um perfil de recuo, com pequenos avanços nos períodos de outono-inverno, que estão claramente representadas pelas colinas dômicas de diamictito, as quais foram interpretadas como morainas de empurrão sazonais. 
Com o recuo da geleira o nivel do mar sobe rapidamente, sendo que em alguns instantes a geleira pode ter-se encontrado aterrada na plataforma marinha rasa recéminstalada, como evidenciam as feições descritas nas superfícies estriadas no topo da seção do morro Siebert (Cap. IV). Evidências dessa primeira grande transgressão marinha encontra-se na seção de Witmarsum (arenitos com estratificação cruzada de baixo ângulo e grande porte).

Em resposta a retirada da geleira, dá-se a compensação glácio-isostática do continente (controle tectônico) e a volta de facies terrestres, associadas as estruturas periglaciais, em Witmarsum. Após este período de recuo acentuado do lobo glacial Paraná, este avança novamente sobre a região, agora sobre sedimentos depositados anteriormente, durante o primeiro avanço. Semelhantemente ao primeiro avanço, a margem glacial apresenta oscilações, rápidos avanços e recuos, produzindo as superfícies estriadas de Palmeira e São Luis de Purunã (Cap. IV). Essas oscilações da frente da geleira podem ter sido controladas por variações climáticas anuais (outono/inverno - primavera/verão) e por mudanças na própria dinâmica glacial. Ainda durante este período o lobo Paraná passou gradativamente de condições terrestres para marinho proximal, como evidencia a superficie estriada D em Palmeira (Cap. III).

Posteriormente, a região deve ter sido submetida a condições de sedimentação glácio-marinha, que é indicada pelas curvas de isoespessura dos intervalos bioestratigráficos $i_{1}$ e $i_{2-4}$. Contudo, devido a intensa erosão submetida durante o arqueamento Mesozóico do arco de Ponta Grossa, as facies relacionadas a este intervalo não estão inteiramente preservadas na área.

O estudo mais detalhado da paleogeografia do flanco sul do arco de Ponta Grossa necessita, ainda, de pesquisa palinológica sistemática. Um estudo inicial foi realizado por Canuto (1985), atribuindo idades, com certo grau de incerteza, correspondentes ao intervalo bioestratigráfico $\mathrm{G}$ e $\mathrm{H}_{1}$ (Estefaniano $\mathrm{C}$ - Sakmariano) aos afloramentos pesquisados nas proximidades da cidade de Palmeira.

A dificuldade e incerteza quanto aos resultados palinológicos deve-se a presença restrita de facies de granulometria mais fina (silte e argila), limitando as rochas passiveis de estudo. Contudo, o método palinológico não é suficientemente preciso para determinar as idades de cada evento deposicional, sendo, portanto, necessário um levantamento estratigráfico de detalhe, que também é dificuldade pela ausência de mapas topográficos de escala adequada. 


\section{VIII - CONSIDERAÇÕES FINAIS}

Resultados da presente pesquisa, acima discutida, permitem identificar o flanco sul do arco de Ponta Grossa como uma região-chave para estudos de Geologia Glacial do neopaleozóico da Bacia do Paraná.

Numerosos aspectos, envolvendo estratigrafia e sedimentologia glacial e de processos de erosão e deposição subglacial e proglacial disponiveis para estudo, oferecem uma visão da história da glaciação neopaleozóica da Bacia do Paraná e das características do lobo glacial Paraná, com um detalhe até então não alcançado em outras partes da Bacia do Paraná. A região oferece ainda a oportunidade de examinar a história glacial, no quadro das alterações ocorridas no condicionamento tectono-estrutural do arco de Ponta Grossa.

Nesse contexto, as mais importantes conclusões atingidas pela presente pesquisa são as seguintes:

a) umas das principais feições geológico-estruturais que cortam a região é a Falha de Cancela, que em estudos de detalhe, realizados durante o mapeamento realizado em Witmarsum, demonstrou possuir componente transcorrente destral. A proximidade da falha Cancela com estruturas glaciotectônicas e sua interferência na estratigrafia da região, exigiram análise acurada. A falha está provavelmente associada ao lineamento estrutural de Lancinha-Cubatão, que está bem visivel no embasamento cristalino e deve continuar por debaixo da Bacia do Paraná;

b) o flanco sul do arco de Ponta Grossa abriga grande número de formas de terreno glaciais erosivas e deposicionais, cuja origem é aqui atribuida a condições tanto subglaciais, quanto proglaciais;

c) a ocorrência de superfícies estriadas múltiplas é extremamente rara em sucessões glaciogênicas pré-pleistocênicas ou recentes, a descoberta de, pelo menos, três outros exemplos na região (Palmeira, São Luís de Purunã e Witmarsum) constitui-se em marco extremamente importante para a Geologia Glacial brasileira e internacional. O processo abrasivo predominante nessas superficies estriadas foi o de aração (plowing). Abas de diamictito cobrindo lateralmente estrias internas a sulcos, como em escorregamentos, são estruturas características de superfícies estriadas formadas sobre substrato glacial inconsolidado;

d) as superfícies estriadas de Palmeira, num total de quatro exposições, formadas sobre arenito, preservaram-se da erosão posterior graças, provavelmente, à cobertura por depósitos silto-argilosos observados, principalmente, sobre as superfícies C e D. A despeito 
de sua origem subglacial e inconsolidada, não há evidências de deformação cisalhante intensa. A única deformação observada reflete-se em fraturas subverticais que cortam o arenito abaixo das superfícies, mas não as afetam. A gênese dessas superfícies está associada à condições terrestres, para as duas primeiras superficies ( $A$ e $B$ ), e de plataforma marinha rasa, para as duas últimas ( $C$ e D), que coincidentemente são as mais extensas no afloramento. Esta constatação pode indicar que o ambiente subaquático seja mais propício para a preservação dessas feições, do que o terrestre;

e) as superfícies estriadas de São Luís de Purunã, com pelo menos duas exposições, foram formadas sobre diamictito subglacial, provavelmente tilito de alojamento. Nestas superfícies associam-se feições deposicionais ou construcionais, cujas caracteristicas apontam para flutes ou cristas de till subglaciais. Semelhantemente às superfícies estriadas de Palmeira, em São Luís de Purunã a superfície principal é coberta por uma espessa camada de silte, o qual foi depositado em condições subaquáticas, possibilitando sua preservação. Três hipóteses para a formação das superfícies estriadas de São Luís de Purunã podem ser aventadas, por geleira terrestre, sendo coberta posteriormente por depósitos flúvio-deltaicos ou coberto por sedimento lacustre subglacial, e aterrada em plataforma marinha rasa, todas, contudo, de difícil comprovação;

f) formas de terreno coliniformes, encontradas na região da Colônia Menonita de Witmarsum, são interpretadas, com base em sua geometria, forma de ocorrência e caracteristicas sedimentológicas, como morainas de empurrão sazonais. A descoberta dessas feições é, pela pesquisa bibliográfica realizada, única no registro de sucessões glaciais pré-pleistocênicas;

g) - Mapa Geológico da Colônia Menonita de Witmarsum (Anexo 1), apresenta cinco unidades mapeáveis na escala 1:25.000. A primeira representada pelos arenitos devonianos da Formação Furnas e as outras, de idade Permo-carbonífera, pertencentes ao Subgrupo Itararé. O mapeamento permitiu levantar, com certo detalhe, a estratigrafia da região da colônia. Um dos produtos deste levantamento foi a descoberta de sucessões de diamictitos, que podem representar uma verdadeira estratigrafia de till, similar às descritas para o Pleistoceno, o que também constitui em um dos aspectos mais atraentes da dissertação aqui apresentada. Outras estruturas associadas aos depósitos glaciogênicos e encontradas durante a realização do mapeamento em Witmarsum, são falhas de colapso e feições periglaciais. As primeiras, ligadas a depósitos flúvio e glácio-lacustres e as segundas, 
representadas por cunhas de areia e clastos partidos, ambas relacionadas a paleosolo perenemente congelado (permafrost);

h) a evolução tectônica neopaleozóica do arco de Ponta Grossa está intimamente relacionada à dinâmica do lobo glacial Paraná e a preservação das formas de terreno acima comentadas, sendo que a ocorrência maciça de pavimentos e superficies estriadas no flanco sul do arco, está associada a subsidência imposta após o intervalo bioestratigráfico $\mathrm{H}$ para esta região, preservando as formas de terreno ali formadas, provavelmente, durante o intervalo $\mathrm{G}-\mathrm{H}_{1}$. A superfície encontrada, inicialmente, pelo lobo glacial Paraná, chamada de pré-Itararé, era extremamente plana (peneplano), formada durante longo período de denudação imposta à região. Essa característica condicionou, provavelmente, a formação de uma base plana para a geleira e sua rápida movimentação pela área, pois não encontrava obstáculos que pudessem diminuir sua velocidade. A subsidência constante da região sul do arco de Ponta Grossa (diagênese), após a formação das formas de terreno, possibilitou sua preservação no registro geológico da Bacia do Paraná, e a configuração atual do arco, gerada principalmente pelo arqueamento juro-cretácico da área, expôs novamente a região. Os ciclos deposicionais identificados revelam a alternância de avanços e recuos da frente da geleira. Esses ciclos foram controlados, principalmente, pela tectônica, elevação e subsidência da área, e pela dinâmica do lobo glacial Paraná, balanço de massa, hidrologia e outros. Os ciclos de ordem maior teriam sido regidos pela tectônica neopaleozóica do arco, e os de menor ordem por variações na dinâmica glacial;

i) as formas de terreno glaciais erosivas e deposicionais e suas relações estratigráficas permitiram inferir diversas conclusões a respeito das características e do comportamento do lobo glacial Paraná, dentre as quais destacam-se, presença de água subglacial, alto gradiente de balanço de massa, pequena espessura e rápido deslizamento da capa de gelo, estabilização da geleira em condições de maré, variação na intensidade erosiva da geleira, ausência de conjuntos de estrias distintos entrecruzantes sugere sua formação, em cada caso, por evento erosivo único e alternância de fases de erosão planar e deposição;

j) o reconhecimento de, pelo menos, duas extensas superficies de abrasão glacial, Rio do Salto e Cancela, sendo que a primeiro ocorre sobre arenitos devonianos da Formação Furnas, e a segundo sobre sedimentos do Subgrupo Itararé;

k) o sentido de fluxo da geleira interpretado para a superficie de abrasão glacial Rio do Salto é, grosso modo, NNW, e nos depósitos glaciogênicos do Subgrupo Itararé, que 
incluem diversos avanços, além do registrado na superfície de abrasão glacial Cancela, é de NNE. O fluxo da geleira foi condicionado, primeiramente, por estruturas do embasamento de direção NW, após esse primeiro avanço, lineamentos de direção NE, ter-se-iam tornado mais ativos na área, impondo direção distinta ao primeiro avanço. 


\section{IX - REFERÊNCIAS BIBLIOGRÁFICAS}

Alley, R.B.; Blankenship, D.D.; Bentley, C.P. e Rooney, S.T.,1987. Till beneath Ice Stream B.3. Till deformation: evidence and implications. Jour. Geophys. Res., 92 (139): 8921 8929.

Almeida, F.F.M. de, 1980. Síntese sobre a Tectônica da Bacia do Paraná. Conferência de Abertura do $3^{0}$ Simpósio Regional de Geologia, p. 1-20.

Almeida, F.F.M. de; Ré Carneiro, C.D. e Cremonini, O.A., 1980. Tectônica da Bacia do Paraná. Relatório $n^{0}$ 14.091, Consórcio CESP/IPT PAULIPETRO, 187p.

Banerjee, I. e McDonald, B.C., 1975. Nature of Esker Sedimentation. SEPM Special Publication, $\mathrm{n}^{\circ} 23$, p. 132-154.

Benn, D.I e Evans, D.J.A., 1998. Glaciers and Glaciation. Arnold, London, 734p.

Bennett, M. T. e Glasser, N. F., 1996. Glacial Geology: Ice Sheets and Landforms. John Wiley e Sons, $364 \mathrm{p}$.

Bigarella, J.J. e Salamuni, R., 1967. some paleogeographic and paleotectonic features of the Paraná Basin. In: J.J. Bigarella, R.D. Becker e I.D. Pinto (Eds.), Problems in Brazilian Gondwana Geology, Curitiba, p. 235-301.

Bigarella, J.J.; Salamuni, R. e Fuck, R.A.,1967. Striated surfaces and related features developed by the Gondwana Ice Sheets (State of Paraná, Brazil). Palaeogeography, Palaeoclimatology, Palaeoecology, 3, art. 56, p. 265-276.

Boulton, G.S., 1974. Processes and patterns of glacial erosion. In: Coates, D.R. (Ed.) Glacial Geomorphology. Proceedings of the Fifth Annual Geomorphology Symposia, Binghampton, Allen e Unwin, London, p. 41-87. (Reprint from Glacial Geomorphology).

Boulton, G.S, 1975. Processes and patterns of subglacial sedimentation: a theorical approach. In: A.E. Wright e F. Moseley (eds.), Ice Ages: Ancient and Modern, pp. 7-42.

Boulton, G.S., 1977. A multiple till sequence by a late Devensian Welsh ice-cap: Glanllynnau Gwynedd. Cambria, 4 (1): 1-31.

Boulton, G.S, 1979. Processes of glacier erosion on different substrata. Journal of Glaciology, $23(89):$ 15-38.

Boulton, G.S, 1982. Subglacial processes and the development of glacial bedforms. In: R. Davidson-Arnott; W. Nickling e B.D. Fahey (eds.), Research in Glacial, Glaciofluvial and Glaciolacustrine System.

Boulton, G.S.,1986. Theory of glacial erosion, transport and deposition as a consequence of subglacial sediment deformation. Jour. Glaciol., 42(140): 43-62.

Boulton, G.S., 1987. A theory drumlin formation by subglacial sediment deformation. In: J. Menzies e J. Rose (Eds.), Drumlin Symposia, p. 25-80.

Boulton, G.S., 1993. Glaciers and Glaciation. In: D. Duff (Ed.), Holmes' Principles of Physical Geology, $4^{\text {a }}$ ed., p. 401-438.

Boulton, G.S e Hindmarsh, R.C.A., 1987. Sediment deformation beneath glaciers: rheology and geological consequences. Jour. Geophys. Res., 92(139):9059-9082. 
Boulton, G.S e Jones, A.S., 1979. Stability of temperature ice caps and ice sheets resting on beds of deformable sediment. Jour. Glaciol., 24(90): 29-43.

Boyce, J.t. \& Eyles, N. (1991) Drumlins carved by deforming till streams below the Laurentide ice sheet. Geology, 19: 787-790;

Brennand, T.A., 1994. Macroforms, large bedforms and rhythmic sedimentary sequences in subglacial eskers, south-central Ontario: implications for esker genesis and meltwater regime. Sedimentary Geology, 91: 9-55.

Campanha, G.A. da C., 1991. Tectônica Proterozóica no Alto e Médio Vale do Ribeira, Estado de São Paulo e Paraná. Tese de Doutoramento. Instituto de Geociências, USP, 296p.

Canuto, J.R., 1985. Origem dos diamictitos e de rochas associadas do Subgrupo Itararé, no sul do Estado do Paraná e norte do Estado de Santa Catarina. Dissertação de Mestrado, Instituto de Geociências, USP, 187p.

Canuto, J.R.; Rocha-Campos, A.C.; Santos, P.R. dos e Sato, P.E.S., 1997. O Arenito Lapa, Subgrupo Itararé (Neopaleozóico), Bacia do Paraná, Brasil: um possivel depósito de vale-túnel. CRONOPAR $-3^{\circ}$ Simpósio Sobre Cronestratigrafia da Bacia do Paraná, $p$. 24-25.

Canuto, J.R.; Rocha-Campos, A.C. e Sato, P.E.S., 1996. Lapa Sandstone (Itararé Subgroup, late Paleozoic): a possible tunnel-valley fill? Sessão Regular da Academia Brasileira de Ciências, Ciências da Terra: "Aspectos de Paleontologia e Geologia Sedimentar", IGc, USP, Programas e Resumos, pp. 23.

Canuto, J.R., 2001. Estratigrafia de seqüências da sucessão sedimentar glaciogênica neopaleozóica da bacia do Paraná: I. Relatório Final. FAPESP, Proc. n 97/13.973-2.

Canuto, J.R.; Santos, P.R. dos e Rocha-Campos, A.C., 2001. Estratigrafia de sequências do Subgrupo Itararé, Neopaleozóico, leste da Bacia do Paraná e norte de Santa Catarina, Brasil. Revista Brasileira de Geociências, 31(1): 107-116.

Castro, J.C., 1999. Estratigrafia de sequências das Formações Campo Mourão (parte superior) e Tacita, Grupo Itararé, leste da Bacia do Paraná. Revista Brasileira de Geociêncais, 29(2): 255-260.

Clark, P.U. e Hansel, A.K., 1989. Clast ploughing, lodgment and glacier sliding over a soft glacier bed. Boreas, 18: 201-207.

Crowell, J.C., 1999. Pre-Mesozoic Ice Ages: Their Bearing on Understanding the Climate System. Geological Society of America, Memoir 192, 106p.

Daemon, R.F. e Quadros, L.P., 1970. Bioestratigrafia do Neopaleozóico da Bacia do Paraná. Anais do $24^{\circ}$ Congresso Brasileiro de Geologia, Brasilia, DF, SBG, p. 359-412.

D'Avila, R.S.F.; Medeiros, R.A. e Carminatti, M., 1995. Arenito Lapa (Grupo Itararé, Bacia do Paraná): exemplo de um vale inciso glacial. $2^{\circ}$ CRONOPAR, UFRGS, p. 57-59.

Drewry, D., 1986. Glacial geological processes. London: Edward Arnold, 271 pp.; 
Elson, J.A., 1988. Comment on glaciotectonite, deformation till and comminution till. In: R.P Gondtwait e C.L. Matsch (eds.). Genetic classification of glacigenic deposits Rotterdam, A.A. Balkema p. 85-88.

Embleton, C. e King, C.A.M., 1975. Glacial geomorphology. London : Edward Arnold, 573p.

Engelhardt, H.; Humphery, N.; Kamb, B. e Fahnestock, M.11991. Physical conditions at the base of a fast moving Antartic Ice Stream. Science, 248(4951)L 57-59.

Eyles, N., 1993. Earth's glacial record and its tectonic setting. Earth-Science Reviews, 35: 1248.

Eyles, C.H.; Eyles, N. e França, A.B., 1993. Glaciation and tectonics in a active intracratonic basin: the Late Paleozoic Itararé Group, Paraná Basin, Brazil. Sedimentology, 40:1-25.

Eyles, C. H.; Eyles, N. e Miall, A. D., 1985. Tillites et tilloids du Massif armoricoin [Tillites and tilloid of the Armorican Massif]. Palaeogeography, Palaeoclimatology, Palaeoecology, 51: $15-84$

Eyles, N.; Sladen, J. A. e Gilroy, S., 1982. A depositional model for stratigraphic complexes and facies superimpositiom in lodgement tills. Boreas, 11: 317-333.

Ferreira, F.J.F., 1982. Integração de dados aeromagnéticos e geológicos: configuração e evolução tectônica do arco de Ponta Grossa. Dissertação de Mestrado, Instituto de Geociências, USP, 169p.

Ferreira, F.J.F.; Moraes, R.A.V.; Ferrari, M.R. e Vianna,, R.B., 1981. Contribuição ao estudo do Alinhamento Estrutural de Guapiara. In: Simpósio Regional de Geologia, 3, Curitiba. Atas..., SBG, 1: 226-240.

Frakes, L.A.; Figueiredo Filho, P.M. de e Fulfaro, V.J., 1969. Possible fossil eskers and associated features from the Paraná Basin, Brazil. Journal Sedimentary Petrology, 38(1): 5-12.

Frakes, L.A. e Crowell, J.C., 1969. Late Paleozoic Glaciation I, South America. Geol. Soc. Amer. Bull., 80:1007-1042.

Frakes, L.A. e Crowell, J.C., 1972. Late Paleozoic glacial geography between the Paraná Basin and the Andean Geosyncline. An. Acad. Bras. Ciênc., 44 (Suplemento): 139145.

França, A.B., 1983. Subdivisão Preliminar do Grupo Itararé. Relatório RT-553/93, Consórcio CESPIIPT PAULIPETRO, 21p.

França, A.B.; Winter, W.R. e Assiene, M.L., 1996. Arenitos Lapa-Vila Velha: um modelo de trato de sistemas subaquosos canal-lobos sob influência glacial, Grupo Itararé (C-P), Bacia do Paraná. Revista Brasileira de Geociências, 26 (1): 43-56.

French, H.M., 1976. The periglacial environment. Longman, Londres, $1^{\text {a }}$ ed., 309p.

French, H.M., 1996. The periglacial environment. Longman, Londres, $2^{\mathrm{a}}$ ed., 309p.

Fuck, R.A., 1966. Nota explicativa da Folha Geológica de Quero-Quero, PR. Contribuição da Comissão da Carta Geológica do Paraná. Bol. Univ. Fed. Do Paraná, Geologia, 19: $21 \mathrm{p}$. 
Fuck, R.A. e Bigarella, J.J., 1967. Glacial and periglacial deposits of the Quero-Quero Geologic Quadrangle. In: Guide Book, I International Symposium on teh Godwana Stratigraphy and Paleontology, Curitiba, Brazil, p. 17-37.

Fuck, R.A.; Bigarella, J.J.; Salamuni, R. e Alessi, A.H., 1965. Folha Geológica de QueroQuero, PR, Escala 4:50.000. Contribuição da Comissão da Carta Geológica do Paraná. Coordenador: J.J. Bigarella. Curitiba.

Fulfaro, V.J., 1971. A evolução tectônica e paleogeográfica da bacia sedimentar do Paraná pelo "trend surface analysis". Tese de Livre Docência. Instituto de Geociências. Universidade de São Paulo, 112p.

Fulfaro, V.J.; Saad, A.R.; Santos, M.V. dos e Vianna, R.B., 1980. Compartimentação e Evolução Tectônica da Bacia do Paraná. In: Geologia da Bacia do Paraná: Reavaliação da Potencialidade e Prospectividade em Hidrocarbonetos. PauliPetro Consórcio CESP/IPT, São Paulo, pp.75-115.

Gordon, J.E.; Whalley, W.B.; Gellatly, A.F. e Vere, D.M., 1992. The formation of glacial flutes: assessment of models with evidence from Lyngsdalen, north Norway. Quaternary Science Reviews, 11: 709-731.

Gowan, A. S., 1998. Methods of till analysis for correlation and provenance studies in Minnesota. In: Patterson, C. J. e Wright, H. E. (eds.), Contributions to Quaternary studies in Minnesota: Minnesota Geological Survey Report of Investigations 49, p. 159178.

Gravenor, C.P. e Rocha-Campos, A.C., 1983. Pattern of late Paleozoic glacial sedimentation on the southeast side of the Paraná Basin, Brazil. Palaeogeography, Palaeoclimatology, Palaeoecology, 43: 1-39.

Hambrey, M.J. e Harland, W.B. (Eds.) 1981. Earth's Pre-Pleistocene Glacial Record. Cambridge University Press.

Hall, K., 1997. Rock Temperatures and Implications for Cold Region Weathering. 1: New Data from Viking Valley, Alexander Island, Antarctica. Permafrost and Periglacial Processes, 8(1): 69-90.

Hallet, B., 1979. A theoretical model of glacial abrasion. Journal of Glaciology, 23(89): 39-50.

Hart, J.K.,1995. Recent drumlins, flutes and lineations at Vertari-Hagafells-Jokull, Iceland. Journal of Glaciology, 41 (139): 596-606.

Hart, J.K. e Smith, B., 1997. Subglacial deformation associated with fast ice flow, from the Columbia Glacier, Alaska. Sedimentary Geology, 111: 177-197.

Hasui, Y. e Oliveira, M.A.F. de, 1984. Província Mantiqueira, Setor Central. In: F.F.M. de Almeida e Y. Hasui (Coords), O Pré-Cambriano do Brasil, p. 308-344.

Holmlund, P., 1988. The internal geometry geometry and evolution of moulins, Storglaciären, Sweden. Journal of Glaciology, 34: 242-248.

Maack, R., 1946. Geologia e Geografia da região de Vila Velha, Estado do Paraná e considerações sobre a glaciação carbonífera no Brasil. Arquivos do Museu Paranaense, v. 5, 303p. 
Martin, H., 1961. The hypothesis of continental drift in the light of recent advances of geological knowledge in Brazil and in south west Africa. Geol. Soc. South Africa, Ann. Alex L. du Foix, Memor. Lectures, v. 64(7), 47p.

Martin, H., 1964. The direction of flow of the Itararé ice sheets in the Paraná Basin, Brazil. Boletim Paranaense de Geografia, 10/15: 25-76.

Martin, H.; Bigarella, J.J. e Salamuni, R., 1960. Ocorrência de arenitos eólicos com estratificação cruzada no Grupo Itararé, PR. Boletin da Universidade do Praraná, Instituto de Geologia, $n^{\circ} 2$, 9p.

Matsch, C. L. e Schneider, A. F., 1986. Stratigraphy and correlation of the glacial deposits of the glacial lobe complex in Minnesota and north complex western Wisconsin. Quaternary Science Reviews, 5: 59-64.

McDonald, B. C. e Shilts, W. W., 1975. Interpretation of faults in glaciofluvial sediments. In: Jopling, A. V. e McDonald, B. C. (eds.), Glaciofluvial and Glaciolacustrine Sedimentation - SEPM. SPEC PUBL., $n^{\circ} 23$, p. 123-131.

Medeiros, R.A.; Thomaz Filho, A. e Roncarati, H., 1971. Projeto Rio Bonito. Relatório DESUL-402, Petrobrás.

Menzies, J. 1987. Towards a general hypothesis on the formation of drumlins. In: J. Menzies e J. Rose (eds.). Drumlin symposium. Rotterdam: Balkema, pp. 9-24;

Menzies, J. (Ed.), 1996. Past Glacial Environments: sediments, forms and techniques, Butterworth-Heinemann, v. 2, 598p.

Milani, E.J., 1997. Evolução Tectono-Estratigráfica da Bacia do Paraná e seu relacionamento com a Geodinâmica Fanerozóica do Gondwana Sul-Ocidental. Tese de Doutoramento (v. 1), Universidade Federal do Rio Grande do Sul, 255p.

Muratori, A.; Fuck, R.A.; Bigarella, J.J.; Salamuni, R.; Palka, J.; Lopes, J.A. e Alessi, A.H., 1965. Folha Geológica de Campo Largo. Escala 1:50.000. Contribuição da Comissão da Carta Geológica do Paraná. Coordenador: J.J. Bigarella. Curitiba.

Northfleet, A.A.; Medeiros, R.A. e Muhlmann, H., 1969. Reavaliação dos dados geológicos da Bacia do Paraná. Bol. Téc. da PETROBRÁS, Rio de Janeiro, 2(3): 291-346.

O'Brien, P.E. e Christie-Blick, N., 1992. Glacially grooved surfaces in the Grant Group, Grant Range, Canning Basin and the extent of Late Palaeozoic Pilbara ice sheets. BMR Journal of Australian Geology \& Geophysics, 13: 87-92.

Oliveira, L.O.A., 1989. Aspectos da evolução termomecânica da bacia do Paraná no Brasil. Revista Brasileira de Geociências, 19: 330-342.

Palka, J.; Trein, E.; Fuck, R.A.; Lopes, J.A.; Muratori, A., 1966. Folha Geológica de Porto Amazonas. Escala 1:50.000. Contribuição da Comissão da Carta Geológica do Paraná. Coordenador: J.J. Bigarella. Curitiba.

Petri, S. e Souza, P. A., 1993. Síntese dos conhecimentos e novas concepções sobre a bioestratigrafia do Subgrupo Itararé, Bacia do Paraná, Brasil. Revista IG, São Paulo, 14(1): 7-18. 
Quintas, M.C.L.; Mantovani, M.S.e Zalán, P.V., 1999. Contribuição ao estudo mecânico da Bacia do Paraná. Revista Brasileira de Geociências, 29 (2): 217-226.

Riccomini, C., 1989. Rift continental do Sudeste do Brasil. Tese de Doutoramento. Instituto de Geociências, Universidade de São Paulo, 304p.

Rocha-Campos, A. C., 1967. The Tubarão Group in the Brazilian portion of the Paraná Basin. In: Problems in Brazilian Gondwana Geology. J.J. Bigarella, R.D. Becker e I.D. Pinto (eds.), International Symposium on Gondwana Stratigraphy and Paleotology. Curitiba, Brazil, p. 27-102.

Rocha-Campos, A. C., 1972. Late Paleozoic of Northern Paraná Basin. In: International Symposium on the Carboniferous and Permian Systems in South America. Excursion Guide-Book. Academia Brasileira de Ciências, IGc-USP, São Paulo, Brasil, 68p.

Rocha-Campos, A. C.; Oliveira, ME.C.B. de; Santos, P.R. dos e Saad, A. R., 1976. Boulder pavements and the sense of movement of late Paleozoic glaciers in central eastern São Paulo State, Paraná Basin, Brazil. Boletim do IG-USP, 7: 149-160.

Rocha-Campos, A. C.; Saad, A. R.; Santos, P. R. dos e Oliveira, M. E. C. B. de, 1977. Algumas feições periglaciais do Subgrupo Itararé (Neopaleozóico), no Estado de São Paulo. Boletim IG, Instituto de Geociências, USP, 8: 55-66.

Rocha-Campos, A. C.; Machado, L.C.R.; Santos, P.R. dos; Canuto, J.R. e Castro, J.C. de, 1988. Pavimento estriado da glaciação neopaleozóica em Alfredo Wagner, Santa Catarina, Brasil. Boletim do IG-USP, Série Científica, 19:39-46.

Rocha -Campos, A. C.; Santos P. R. dos; Canuto, J. R., 1999. Multiple, glacially striated, soft sediment surfaces in the late Paleozoic and Proterozoic of Brazil. In. Sessão de Ciências da Terra, São Paulo, SP. Anais da Academia Brasileira de Ciências ,Rio de Janeiro, RJ, Academia Brasileira de Ciências, 71, n. 4-ł, p. 841.

Rocha-Campos, A. C.; Santos, P.R. dos e Canuto, J.R., 2000. Late Paleozoic Glaciotectonic Structures in Northern Paraná Basin, Brazil. Sedimentary Geology, 130: 131-143.

Rocha-Campos, A.C. e Santos, P.R. dos., 2001. Ação Geológica do Gelo. In: Teixeira, W; Toledo, M.C.M. de; Fairchild, T.R. e Taioli, F. (eds.), Decifrando a Terra. Oficina de textos, pp.215-246.

Rocha-Campos, A.C.; Santo, P.R. dos e Canuto, J.R. Multiple, glacially striated soft sediment surface in the late Paleozoic and Proterozoic of Brazil. Sedimentary Geology (no prelo).

Saad, A. R., 1977. Estratigrafia do Subgrupo Itararé no Centro e Sul do Estado de São Paulo. Dissertação de Mestrado, Instituto de Geociências, USP, 107p.

Santos, P.R. dos, 1987. Facies e evolução paleogeográfica do Subgrupo Itararé / Grupo Aquidauana (Neopaleozóico) na Bacia do Paraná, Brasil. Tese de Doutoramento, Instituto de Geociências, Universidade de São Paulo, 128 p. (inédita).

Santos, P.R. dos; Rocha-Campos, A. C. e Canuto, J.R., 1992. Estruturas de arrasto de icebergs em ritmito do Subgrupo Itararé (neopaleozóico), Trombudo Central, RS. Boletim IG-USP, Série Cientifica, 23:1-18. 
Santos, P.R. dos, Rocha-Campos, A.C. e Canuto, J.R., 1996. Patterns of late Paleozoic deglaciation in the Paraná Basin, Brazil. Palaeogeography, Palaeoclimatology, Palaeoecology, 125:165-184.

Schneider, R.L.; Muhlmann, H.; Tommasi, E.; Medeiros, R.A.; Daemon, R.F. e Nogueira, A.A., 1974. Revisão estratigráfica da Bacia do Paraná. Anais do XXVIII Congresso Brasileiro de Geologia, SBG, Porto Alegre, RS, 1: 41-65.

Sharp, M., 1982. Modification of clasts in lodgement tills by glacial erosion. Journal of Glaciology, 28 (100): 475-481.

Shaw, J., 1983. Drumlin formation related to inverted erosion marks. Journal of Glaciology, 29: 461-479;

Shaw, J., 1994. Hairpin erosional marks, horseshoe vortices and subglacial erosion. Sedimentary Geology, 91: 269-283.

Smalley, I.J. e Unwin, D.J., 1968. The formation and shape of drumlins and their distribution and orientation in drumlin fields. Jour. Glaciol., 7: 337-390.

Spencer, A. M., 1985. Mechanisms and environments of deposition of the late Precambrian geosynclinal tillites: Scotland and East Greenland. Palaeogeography, Palaeoclimatology, Palaeoecology, 51: 143-158.

Tomazelli, L.J. e Soliani Jr., E., 1982. Evidências de atividade glacial no Paleozóico Superior do Rio Grande do Sul, Brasil. Anais do XXXII Congresso Brasileiro de Geologia, SBG, Salvador, 4: 1378-1391.

Tommasi, E., 1973. Geologia do flanco sudeste da Bacia do Paraná, Rio Grande do Sul, Santa Catarina e Paraná. Anais do XXVIII Congresso Brasileiro de Geologia, SBG,Porto Alegre, RS, 3: 179-188.

Tommasi, E. e Roncarati, H., 1970. Geologia de semi-detalhe do NE de Santa Catarina e SE do Paraná. Relatório DESUL, PETROBRÁS, 388p.

Tomio, A., (em preparação). Estilos de deformações subglaciais no Subgrupo Itararé, Neopaleozóico da Bacia do Paraná. Tese de doutoramento (inédita).

Trein, E.; Fuck, R. A.; Lopes, J. A.; Muratori, A. e Palka, J., 1965. Folha Geológica de Contenda. Escala 1:50.000. Contribuição da Comissão da Carta Geológica do Paraná. Coordenador: J.J. Bigarella. Curitiba.

Trosdtorf Jr., I., 1998. Caracterização estratigráfica, faciológica e hidrogeológica do arenito Lapa, Subgrupo Itararé (P-C), norte do Estado de Santa Catarina e sul do Estado do Paraná. Monografia de Trabalho de Formatura, $53 \mathrm{p}$.

Trosdtorf Jr., I., Rocha-Campos, A. C.; Tomio, A.; Santos, P. R. dos e Canuto, J. R., 2001. Origin and preservation of stratigraphically repeated, glacially striated surfaces in the Itararé Subgroup (late Paleozoic) in Palmeira, State of Paraná. Anais da Academia Brasileira de Ciências, 73(3): 467-468.

Van der Wateren, F. M., 1995. Structural Geology and sedimentology of Push Moraines. Mededelingen Rijks Geologische Dienst, 54: 1-168. 
Vesely, F.F. e Assine, M.L., 1998. Evidências de sedimentação subglacial na base do Grupo Itararé, Estado do Paraná. Anais do XL Congr. Bras. Geol., Belo Horizonte, SBG-MG, pp. 523.

Vieira, A.J., 1973. Geologia do centro e nordeste do Paraná. Anais do XXVIII Congr. Bras. Geol, SBG, 3: 259-278.

Walker, R.G., 1992. Facies Models, response to sea-level chage. In: R.G. Walker e N.P. James (eds.), Geological Association of Canada, 407p.

Williams, P.J. e Smith, M.W., 1989. The frozen Earth: fundamentals of geocryology. Cambridge: Cambridge Universtiy Press, 306p.

Wu, F.T., 1989. Proveniência das rochas arenosas do Sugrupo Itararé no sul do Estado de São Paulo. Tese de doutoramento, Instituto de Geociências - USP, 165p.

Zalán, P.V., Wolff, S., Conceição, J.C. de J., Astolfi, A.M., Appi, V.T., Wolff, S., Vieira, I.S. e Marques, A., 1985. Estilos estruturais relacionados a intrusões magmáticas básicas em rochas sedimentares. Boletim Técnico da PETROBRÁS, 28: 221-230.

Zalán, P.V., Wolff, S., Conceição, J.C. de J., Astolfi, A.M., Vieira, I.S., Appi, V.T., Zanotto, O. e Marques, A., 1991. Tectonic and sedimentation of the Paraná Basin. In: H. Ulbrich e A.C. Rocha-Campos, Gondwana Seven Proceedings, pp. 83-117.

Zalán, P.V.; Wolff, S.; Conceição, J.C. de J.; Marques, A.; Astolfi, M.A.M.; Vieira, I.S.; Appi, V.T. e Zanotto, O.A., 1990. Bacia do Paraná. In: G.P. Hapa Gabaglia e E.J. Milani (Coords.), Origem e Evolução de Bacias Sedimentares. PETROBRÁS, pp. 135-168. 
AnEXOS 
ANEXO 1 


\section{MAPA GEOLÓGICÓDA COLÔNIA MENONITA DE WITMARSUM}

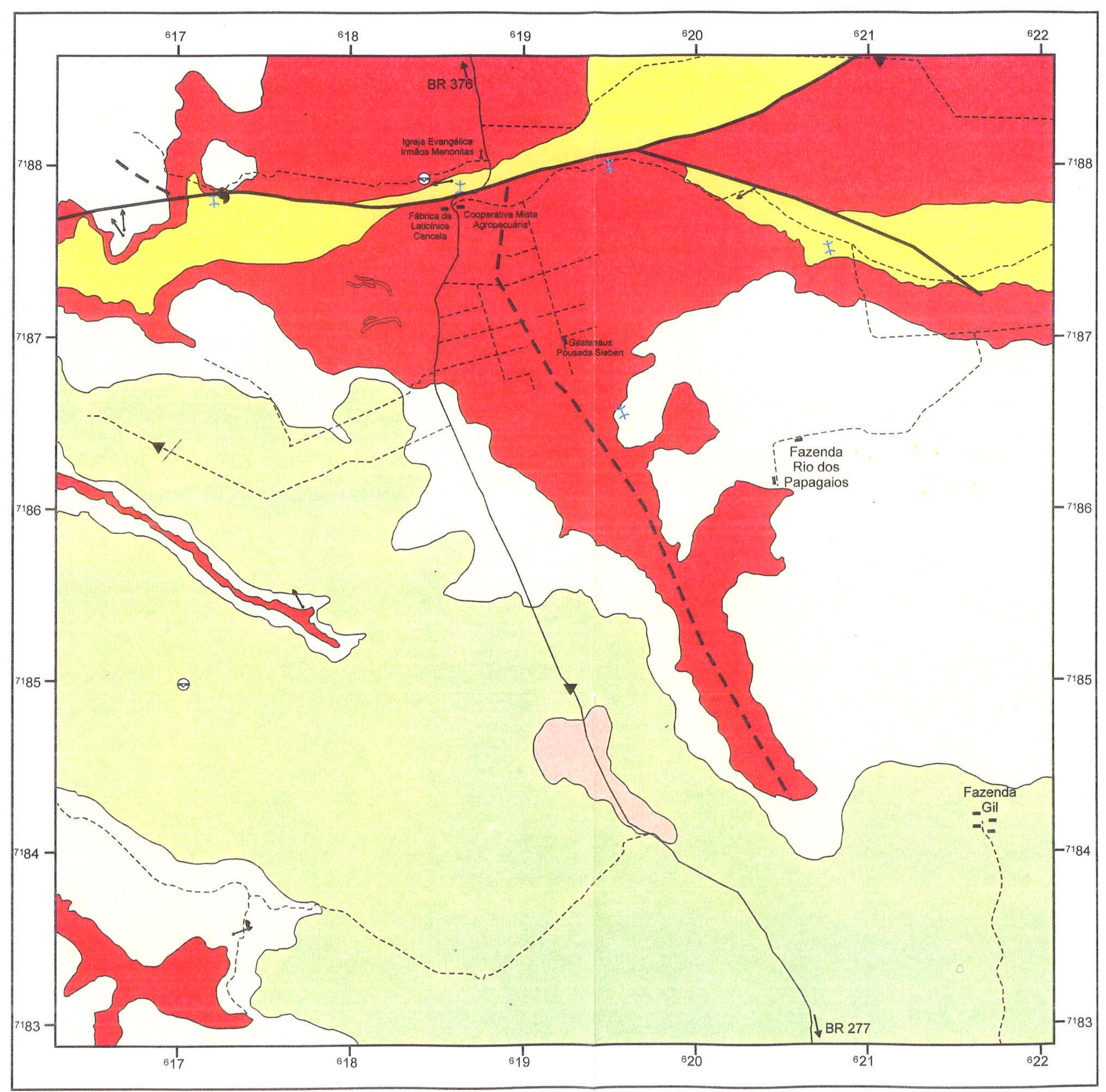

Escala 1: 25000

\section{L e g e $n d a$} Unidade 5: diamicito amarelo, arenoso, clastos mm a cm, maciço; siltito branco com branco, clasto mms, subangulosos, maciço.

Unidade 4: diamictito vermelho, silto-arenoso, clastos $\mathrm{mm}$ a $\mathrm{cm}$, estratificado; diamicito amarelo, sitto-arenoso, clastos $\mathrm{mm}$ a $\mathrm{cm}$; arenito fino-médio, ocre,
feldspótico, granodecrescência ascendente e laminaçăo cruzada acanalada: feldspático, granodecrescência ascendente e lamina
arenito muito fino/siltito, ocre, laminaçăo plano-paralela.

Unidade 3: arenito grosso, quartzoso, estratificaçăo cruzada tabular e bidirecional; diamictito arenoso, avermelhado, com clastos mms e cms; arenito fino-médio, ocre, feldspático, raros clastos dispersos, estratificaçăo cruzada acanalada e tangencial: arenito médio, ocre, lentes conglomeráticas, estratificaçăo cruzada plano-paralela e de baixo ângulo. Unidade 2: diamicito arenoso, ocre a amarelado estratificado, clastos cms a mms;
arenito fino, laminaçăo cruzada acanalada e com raros clastos; diamictitos vermelho, branco e amarelo, matriz silto-argilosa, clastos $\mathrm{mm} e \mathrm{~cm}$, muitas vezes estratificado; diamicito silto-arenoso, cinza, rico em clastos $\mathrm{mm}$ e cm, com lentes de arenitos deformadas; arenito médio-grosso, ocre, estratificaçăo cruzada acanalada e apresentando pequenas dobras.

Unidade 1 - (Embasamento da área): Arenito fino a médio-grosso, branco, Unidade 1 - (Embasamento da área): Arenito fino a medio-grosso, branco,
quartzoso a feldspático, com longas estratificaçọos cruzadas tangenciaise de baixo
angulo. angulo. Falha transcorrente com componente vertical de cavalgamento e inferida ou sem
dados cinemáticos

Estrada asfaltada

....' Estrada de terra

¿ Igreja

$\boldsymbol{\nabla}$ Estruturas em forma de cunha (wedges)

Clastos partidos

(๑) Outras feiçöes sugestivas de clima periglacial

Paleocorrente

× Pavimento ou superficie estriada e/ou sulcada

Lineaçăo de partiçăo

Morainas de empurrão com morfologia glacial preservada

ANEXO 1

MAPA GEOLÓGICO DA COLONNIA MENONITA DE WITMARSUM Dissertaçăo de Mestrado: Geologia Glacial Permo-Carbonffera (Subgrupo Itararé) no flanco sul do arco de Ponta Grossa, PR.

Orientedor Prof Dr Anto 
AneXo 2 


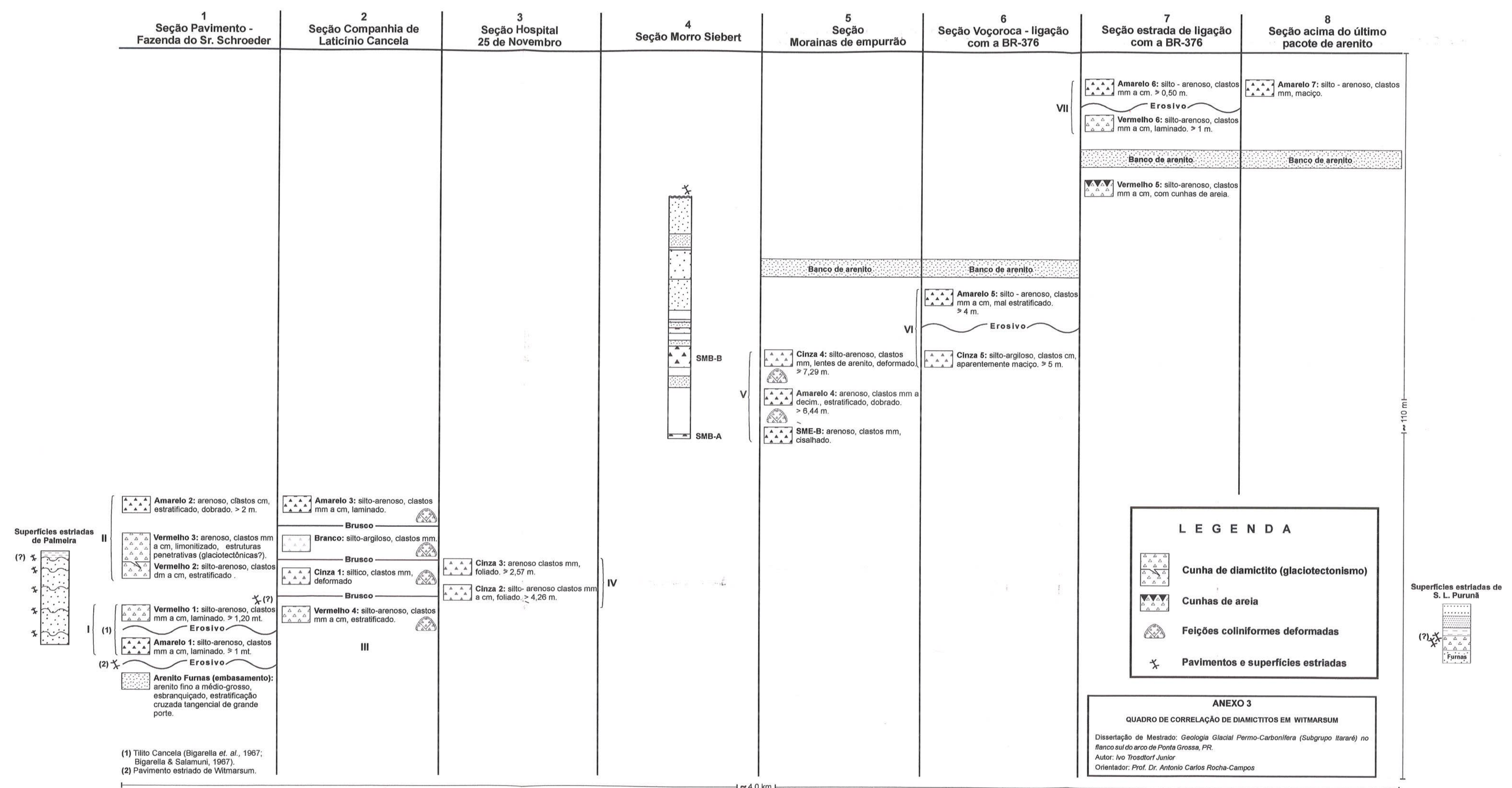

Anexo 3: Distribuiçăao estratigráfica esquemática de diamictitos da área da Colônia Witmarsum e áreas adjacentes (Palmeira e Săo Luís do Purună). A correlaçăo estratigráfica entre sucessőes de diamictitos das seç̋̋es 1 - 4 e entre

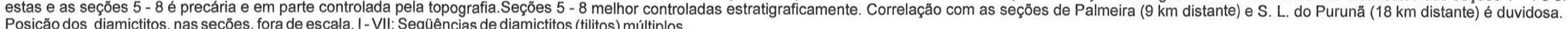


Anexo 3 
Seção Colônia Menonita de Witmarsum - BR 277

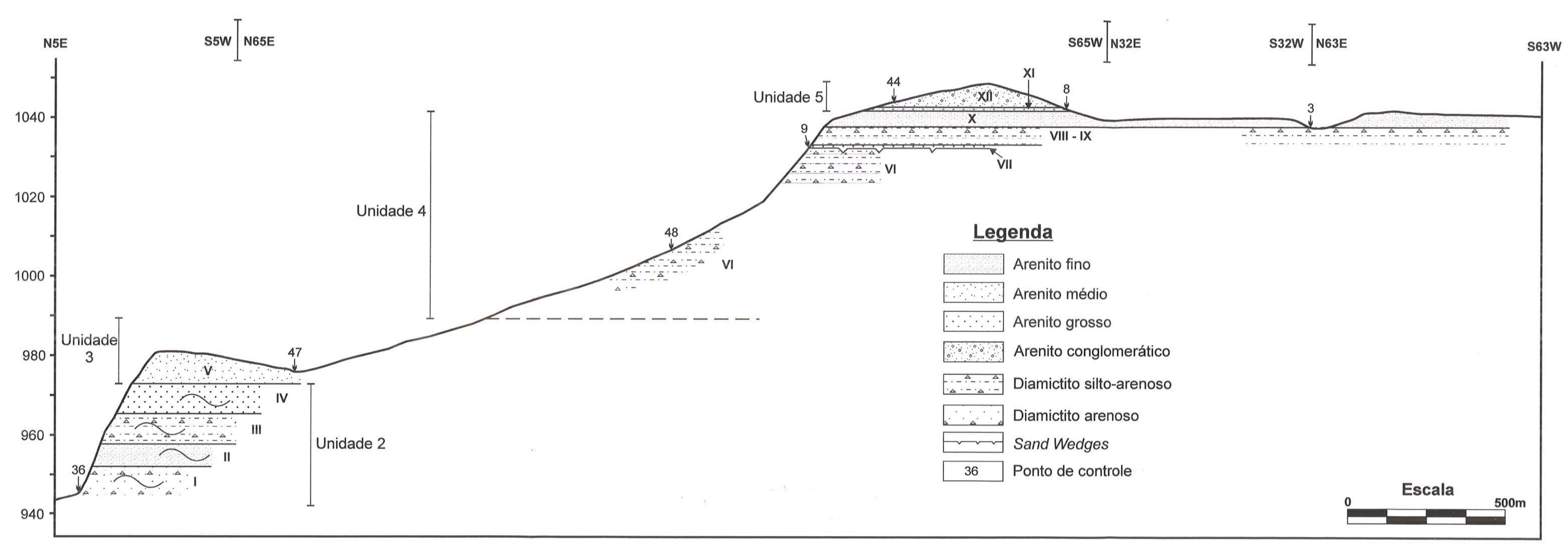

Anexo 2: Seção levantada na estrada de ligação a BR-277. Unidades mapeadas indicadas na seção.

ANEXO 2

SEÇÃO GEOLOGICA DA COLONIA DE WITMARSUM - BR 277

Dissertaçăo de Mestrado: Geologia Glacial Permo-Carbonffera (Subgrupo ltararer) no flanco suld do arco de Ponta Grossa, PR.

Autor: Ivo Trosdtorf Junior
Orientador: Prof. Dr. Antonio Carlos Rocha-Campos 